\title{
Development and Evaluation of High Performance Fiber Reinforced Concrete as a Repairing Material
}

\author{
Manish Roy \\ West Virginia University
}

Follow this and additional works at: https://researchrepository.wvu.edu/etd

\section{Recommended Citation}

Roy, Manish, "Development and Evaluation of High Performance Fiber Reinforced Concrete as a Repairing Material" (2011). Graduate Theses, Dissertations, and Problem Reports. 4777.

https://researchrepository.wvu.edu/etd/4777

This Thesis is protected by copyright and/or related rights. It has been brought to you by the The Research Repository @ WVU with permission from the rights-holder(s). You are free to use this Thesis in any way that is permitted by the copyright and related rights legislation that applies to your use. For other uses you must obtain permission from the rights-holder(s) directly, unless additional rights are indicated by a Creative Commons license in the record and/ or on the work itself. This Thesis has been accepted for inclusion in WVU Graduate Theses, Dissertations, and Problem Reports collection by an authorized administrator of The Research Repository @ WVU. For more information, please contact researchrepository@mail.wvu.edu. 


\title{
Development and Evaluation of High Performance Fiber Reinforced Concrete as a Repairing Material
}

\author{
Manish Roy
}

Thesis submitted to the College of Engineering and Mineral Resources at West Virginia University in partial fulfillment of the requirements for the degree of

Master of Science

Civil Engineering

Indrajit Ray, Ph.D., Chair

Julio F. Davalos, Ph.D., Co-Chair

An Chen, Ph.D.

Department of Civil and Environmental Engineering

Morgantown, West Virginia

2011

Keywords: HPFRC; Concrete; Repairing; Bond, Shear; Tension; Fiber 


\section{ABSTRACT \\ Development and Evaluation of High Performance Fiber Reinforced Concrete as a Repairing Material}

\section{Manish Roy}

Concrete is the most widely used man-made material in the world and is second only to water in terms of its utilization. Annually, 6 billion tons of concrete is produced in the world and the US consumption of concrete is over 2.5 tons a year per person (SDC Vision 2030 - US Concrete Industry). It drives a US $\$ 100$ billion industry in the United States alone employing over 2 million people. It enjoys huge acceptability over other construction materials across the globe. Though concrete is strong and durable, it does not last forever, especially when exposed to aggressive conditions. Deicing salts, freeze-thaw cycles, high heat, high mechanical loading, seismic events, etc. lead to potential deterioration of the concrete structure. As a consequence, the service life of the structure is reduced. In US, 1 in every 4 bridges is either structurally deficient or functionally obsolete. The nation's crumbling infrastructures and buildings need urgent replacement. The replacement cost of these structures being enormous, there is a pressing need for repairing and rehabilitating these deficient structures.

Keeping the above points in mind, the present study focused on developing a high performance fiber reinforced concrete (HPFRC) material with very high strength and improved ductility, which can rehabilitate the structure by repairing it at a fraction of replacement cost required for new construction.

All the materials used in this study are commercially available in the United States. Initially two HPFRC mixtures were developed using portland cement, two types of fine sand with optimized grading, ultrafine quartz powder, discontinuous steel fibers, and a next generation polycarboxylate-based full range water reducing admixture. The water to cementitious materials ratio and the fiber volume fraction were kept at 0.2 and $2 \%$, respectively. To study the effect of curing temperature on the hardened properties of the mixtures, four different curing conditions were selected. Compressive strength, flexural strength, and flexural toughness were determined for those eight combinations. Compared to high performance fiber reinforced cement composites (HPFRCC) the increase in compressive strength was in the range of $25-105 \%$. Flexural strength was found to be similar to that of HPFRCC. Based on these strength results, the better performing mixture and the two best performing curing conditions were further selected to study the bond behavior of HPFRC to NC.

The bond strength was determined by conducting three tests, such as, direct shear, slant shear, and pull-off. The results showed comparable bond strength in case of direct shear and $20 \%$ increase in bond strength by slant shear, when compared with other similar studies. The pull-off strength exceeded the minimum acceptance criterion for bond strength of repairing materials per International Concrete Repair Institute - Technical Guidelines. 
To my beloved mother 


\section{ACKNOWLEDGEMENTS}

First of all, I would like to express my sincerest gratitude towards my advisor Dr. Julio F. Davalos for providing me with the opportunity to embark upon graduate study. His continuing support and encouragement guided me throughout the two years of my Master's program. I also feel privileged to work under him as a Teaching Assistant. His passion for teaching inspired me immensely.

My sincere appreciation also goes to Dr. Indrajit Ray, the Chair of my thesis committee, for his able guidance and tremendous help throughout my research. His vast knowledge in concrete technology was instrumental in successful accomplishment of my tasks. I was fortunate to work under him.

I am thankful to Dr. An Chen for his technical inputs and willingness to serve as a committee member.

I greatly appreciate Dr. David B. DeVallance for allowing me to use the MTS machine in Forestry department. Whenever I faced problem, he was there to solve it with a smiling face. I also wish to thank Dr. Brijes Mishra for allowing me to use the MTS machine in Mining Engineering department. This proved to be an immense help from the perspective of my research outcomes.

I thank Mr. David Turner for his immense technical assistance in the concrete laboratory. I would like to thank Diachao Nie and Priyesh Verma for helping me perform the compressive and flexural strength tests. I thank Kevin Prendergast, Greg Donnelly, Pengcheng Jiao, Subhadeep Ghosh, Arkamitra Kar, Soumyasundar Chowdhury, Mehrzad Zahabi, and John Wattick for helping me in pouring concrete and other associated tasks. I would also like to thank other members of B11 for making graduate life more bearable.

I thank Armstrong Cement \& Supply, Arrow Concrete (WV), BASF Construction Chemicals, Bekaert, Ricci Brothers Sand Co. Inc., and US Silica Company (WV) for generously donating the materials.

I am grateful to my elder brother and friends back in India for taking care of my mother in my absence. 


\section{TABLE OF CONTENTS}

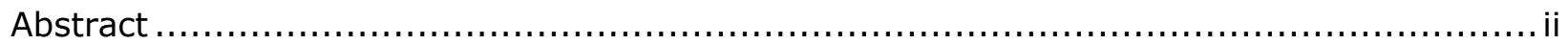

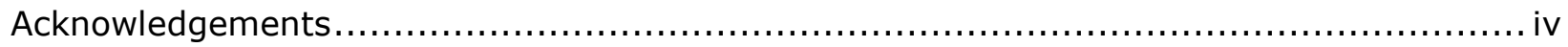

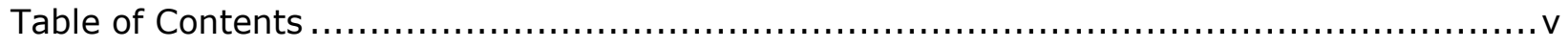

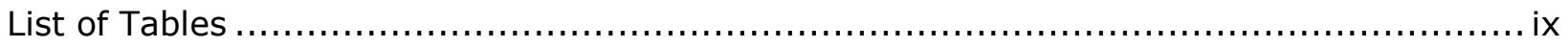

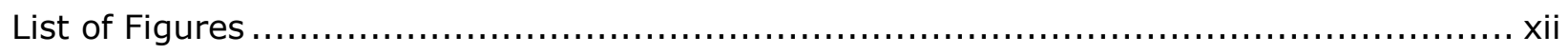

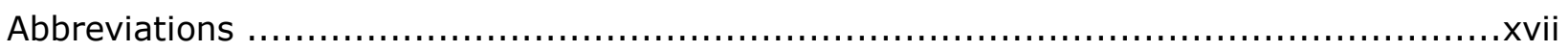

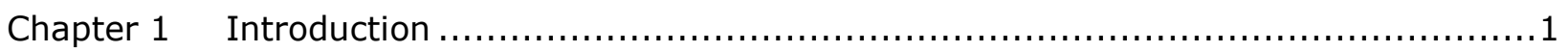

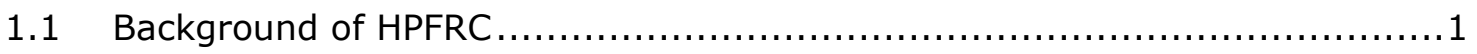

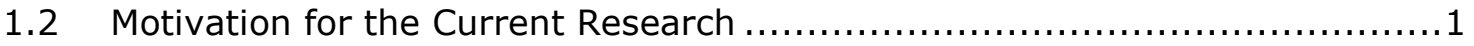

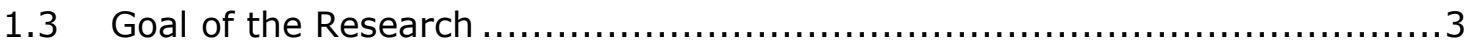

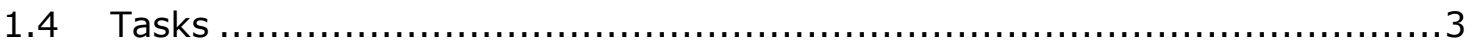

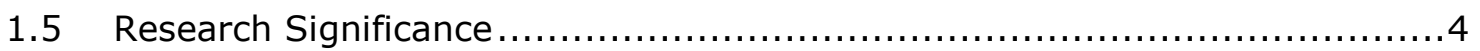

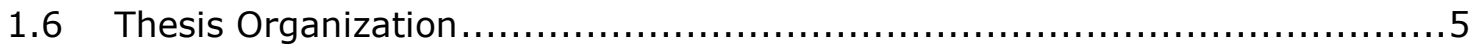

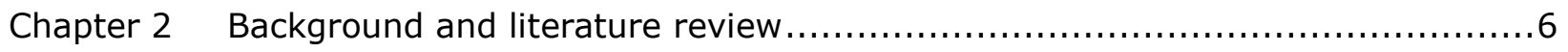

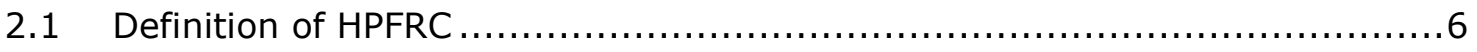

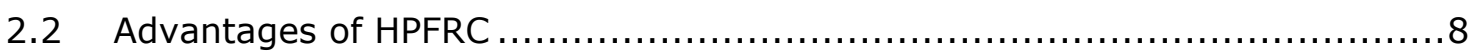

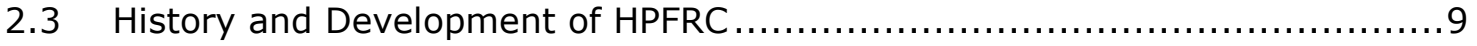

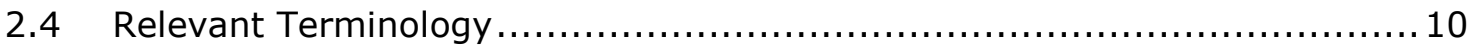

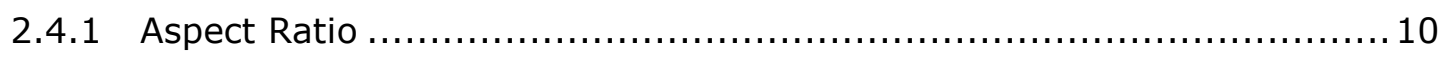

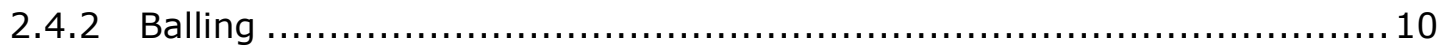

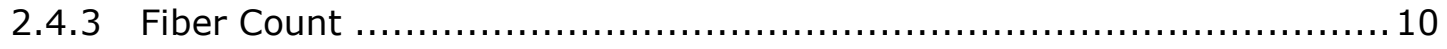

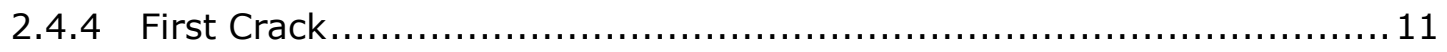

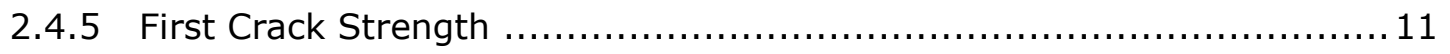

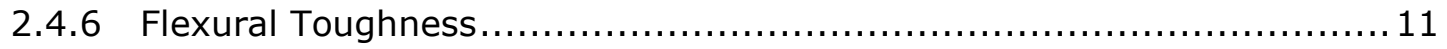

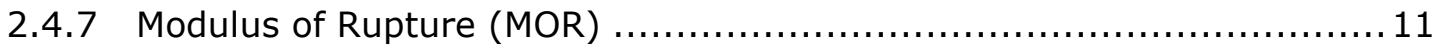

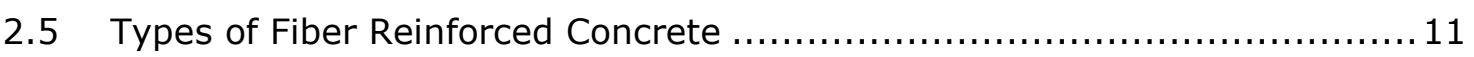




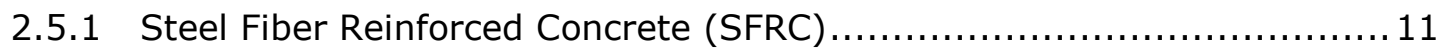

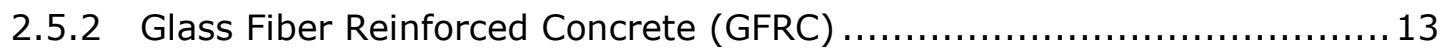

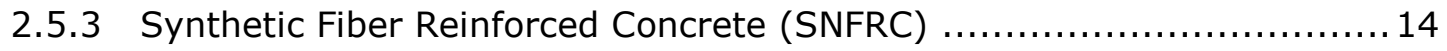

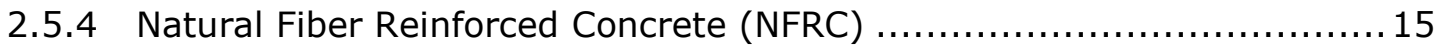

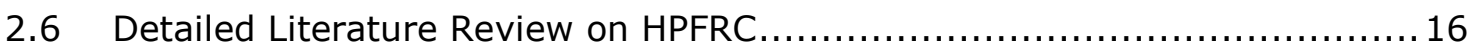

2.6.1 Properties of freshly-mixed HPFRC.................................. 16

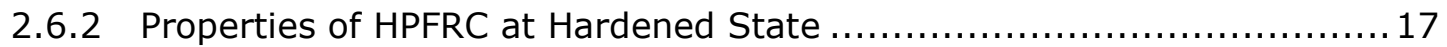

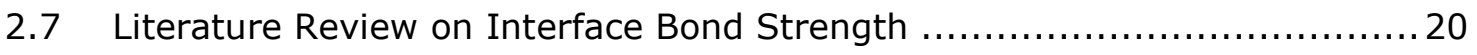

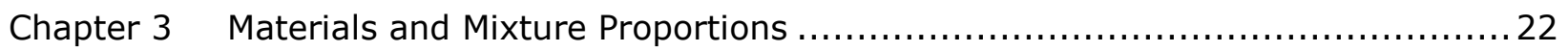

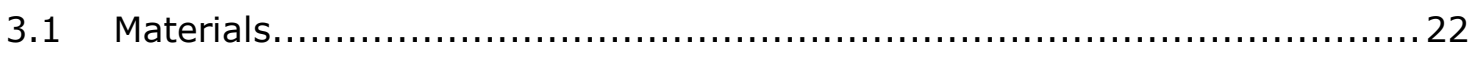

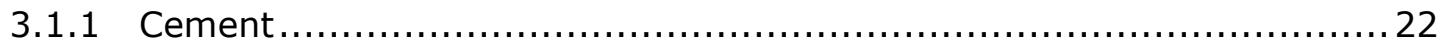

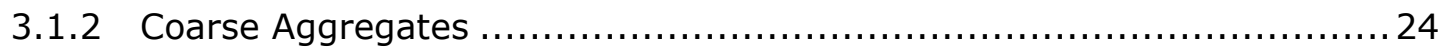

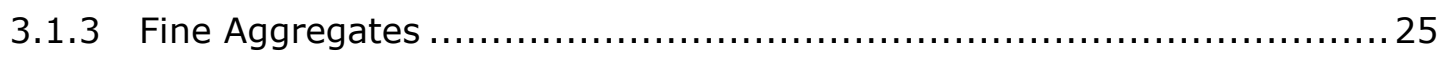

3.1.4 Mineral Admixtures...................................................... 29

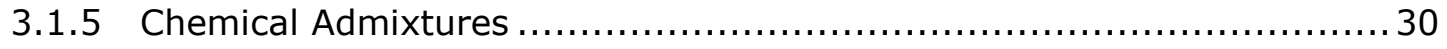

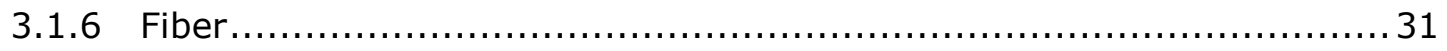

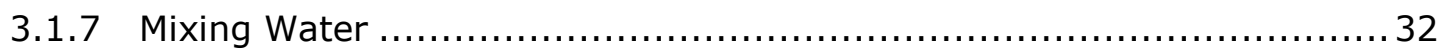

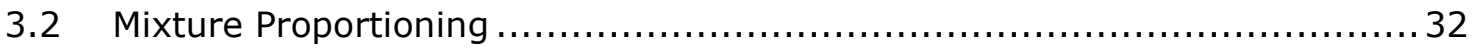

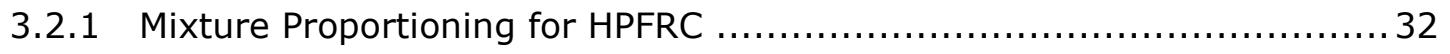

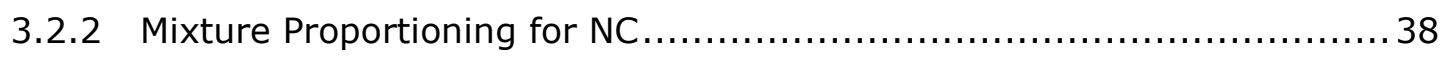

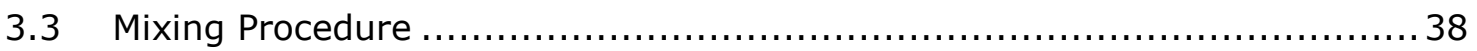

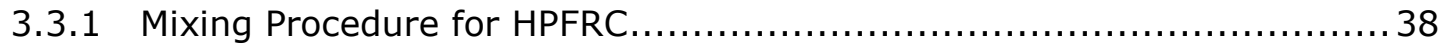

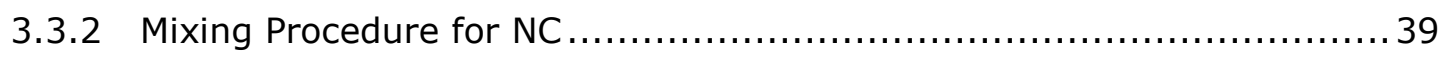

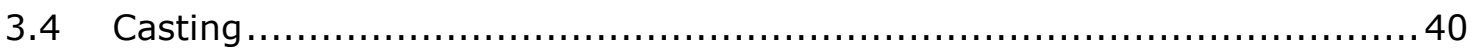

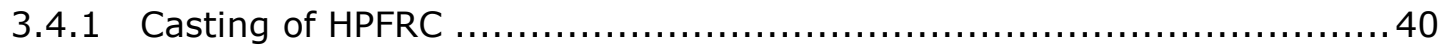

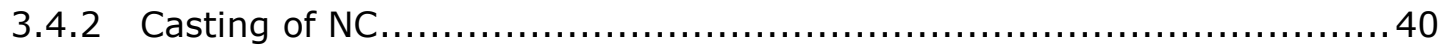

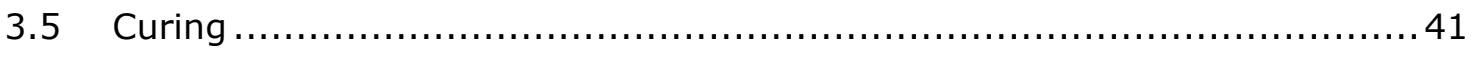

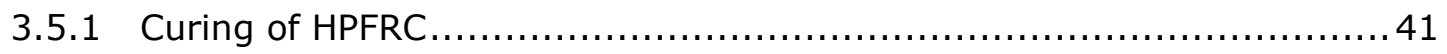




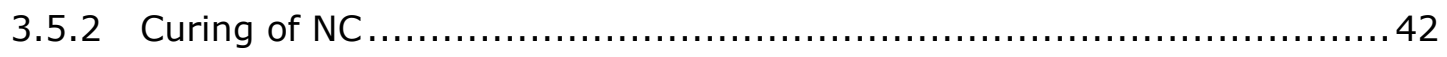

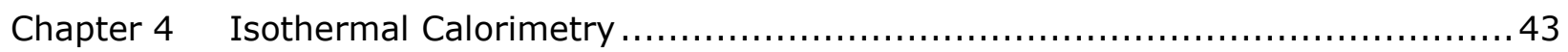

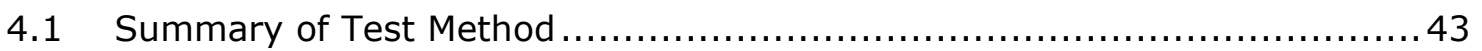

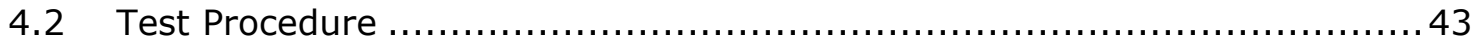

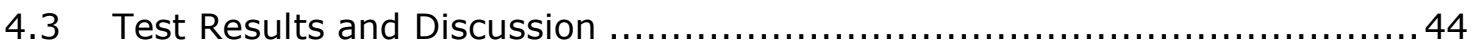

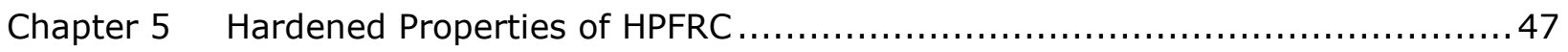

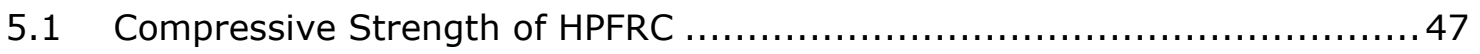

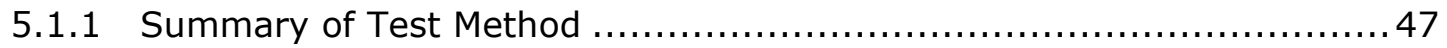

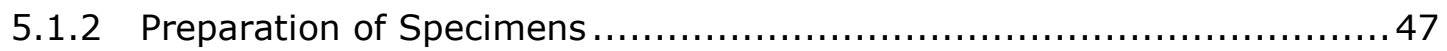

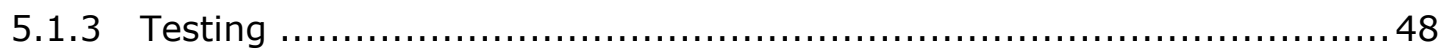

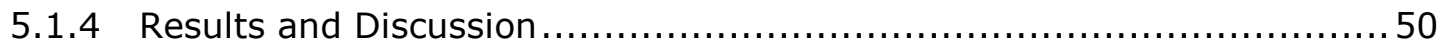

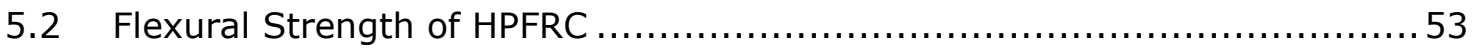

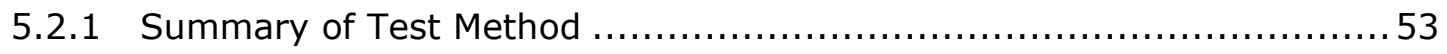

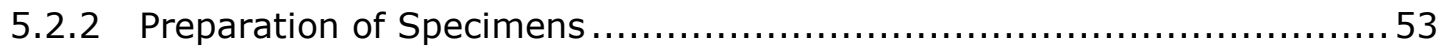

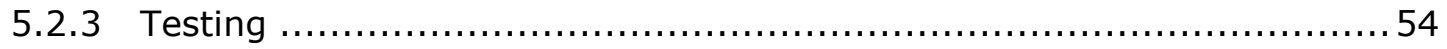

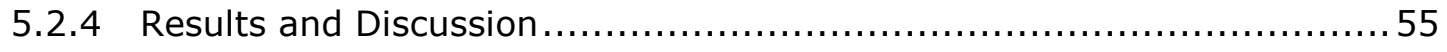

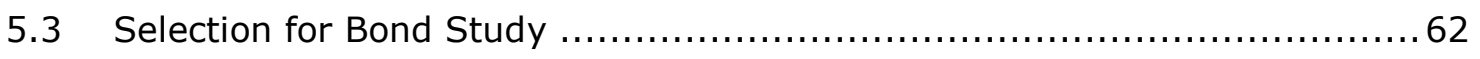

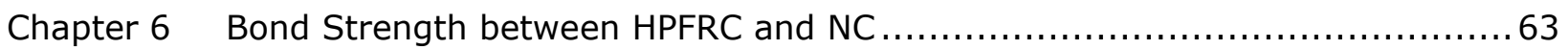

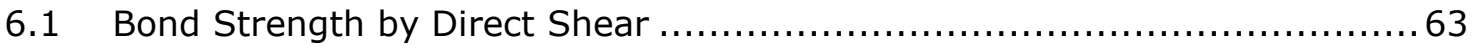

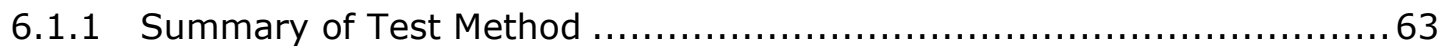

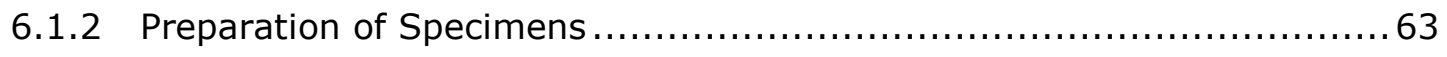

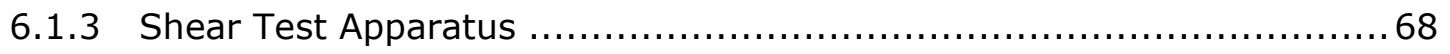

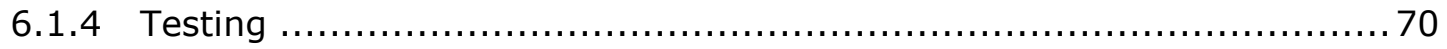

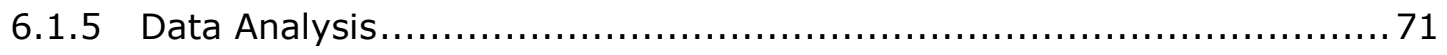

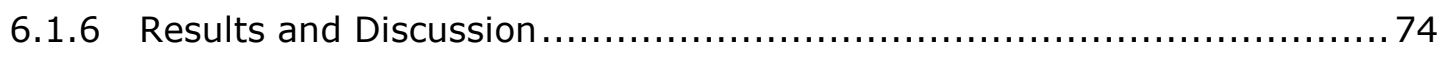

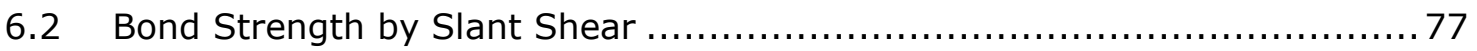

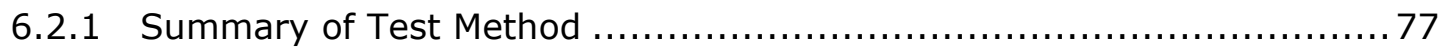

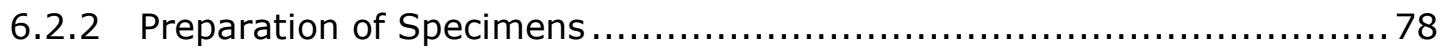




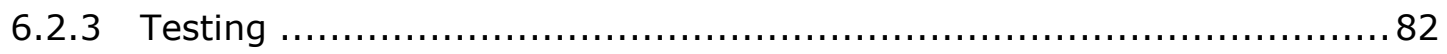

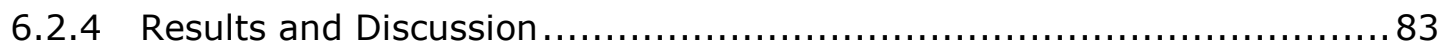

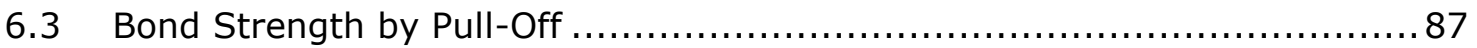

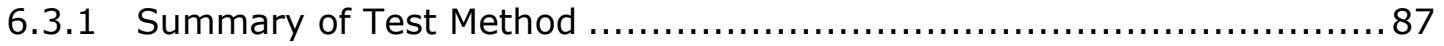

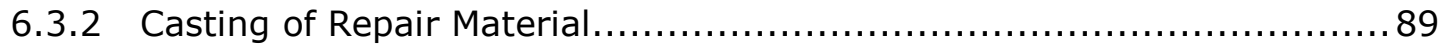

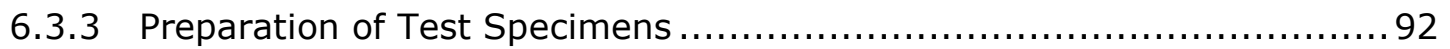

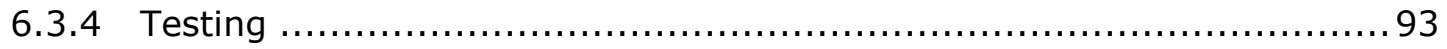

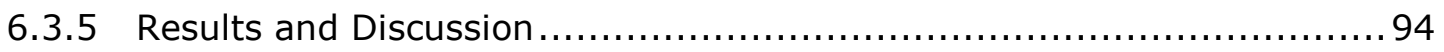

6.4 Comparison of Bond Strength by Different Tests ........................ 97

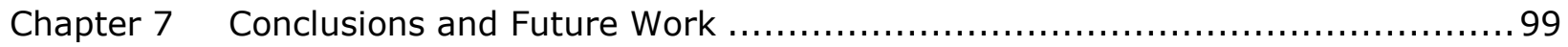

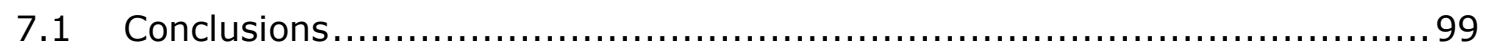

7.1.1 Materials and Mixture Proportions....................................... 99

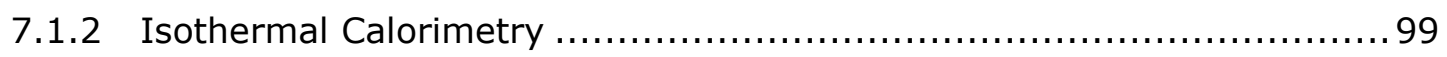

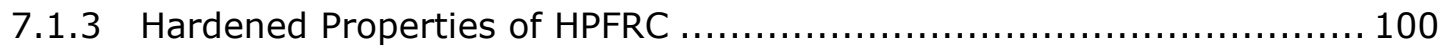

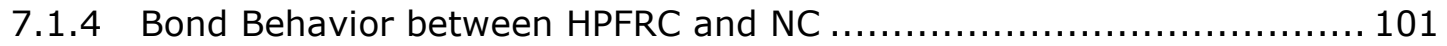

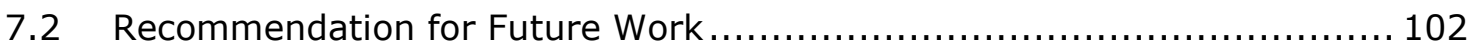

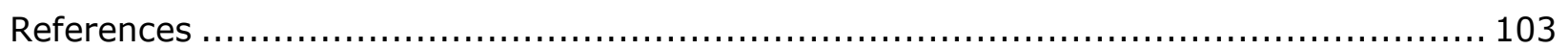

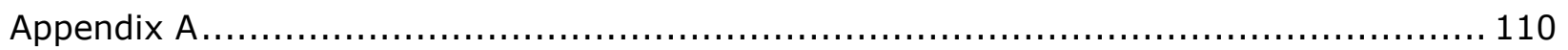

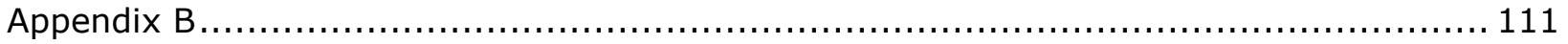

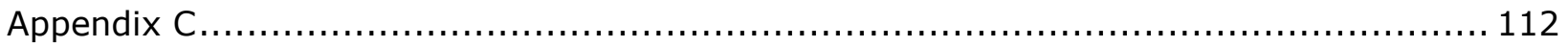

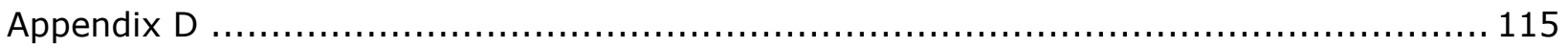




\section{LIST OF TABLES}

\section{MAIN PART}

Table 2.1 Chemical composition of different glass fibers (from ACI $544.1 \mathrm{R}$ ) .......... 14

Table 2.2 Physical properties of different glass fibers (from ACI $544.1 \mathrm{R}$ ) ............. 14

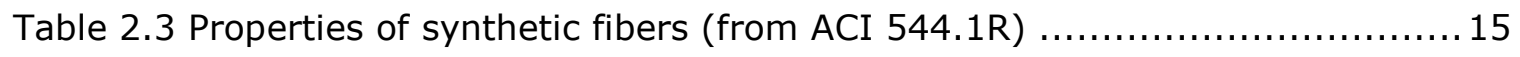

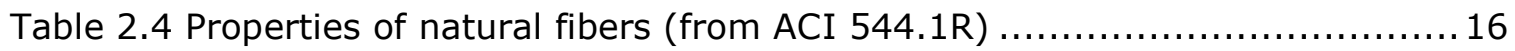

Table 3.1 Physical properties of portland cement used for HPFRC $\ldots \ldots \ldots \ldots \ldots \ldots \ldots \ldots \ldots \ldots \ldots \ldots \ldots$

Table 3.2 Compound compositions of portland cement used for HPFRC ............... 23

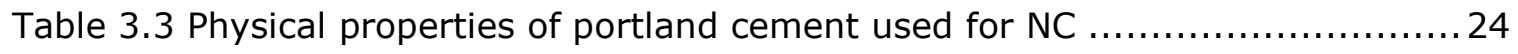

Table 3.4 Compound compositions of portland cement used for NC ................. 24

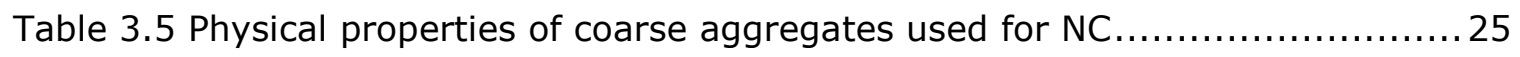

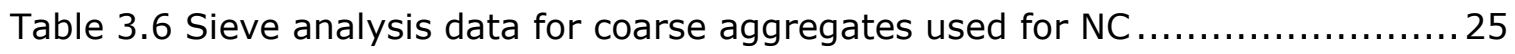

Table 3.7 Physical properties of fine natural sand used for HPFRC $\ldots \ldots \ldots \ldots \ldots \ldots \ldots \ldots \ldots \ldots \ldots \ldots \ldots \ldots$

Table 3.8 Sieve analysis data for fine natural sand used for HPFRC.................. 26

Table 3.9 Major compound compositions of fine natural sand used for HPFRC $\ldots \ldots . .27$

Table 3.10 Physical properties of ultrafine quartz powder used for HPFRC $\ldots \ldots \ldots \ldots . . .27$

Table 3.11 Sieve analysis data for ultrafine quartz powder used for HPFRC $\ldots \ldots \ldots . .27$

Table 3.12 Compound compositions of ultrafine quartz powder used for HPFRC..... 28

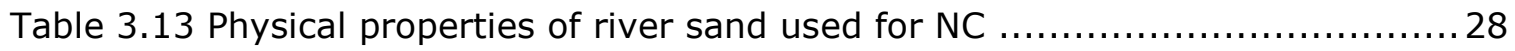

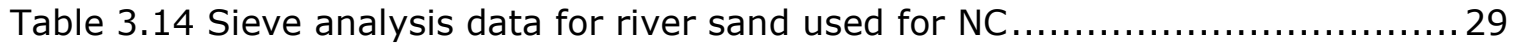

Table 3.15 Basic properties and major chemical compositions of silica fume ..........30 
Table 3.16 Geometric and material properties of steel fibers $\ldots \ldots \ldots \ldots \ldots \ldots \ldots \ldots \ldots \ldots \ldots \ldots \ldots \ldots \ldots$

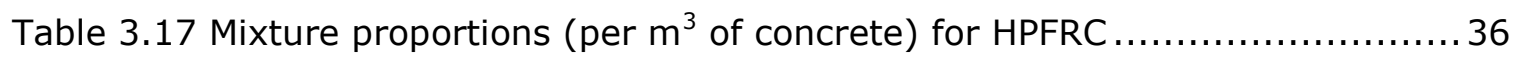

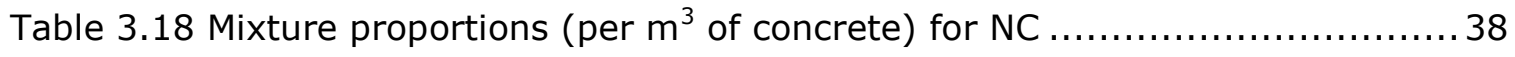

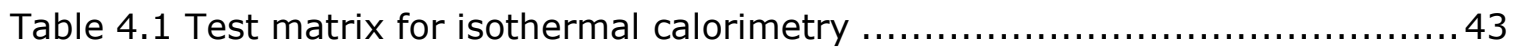

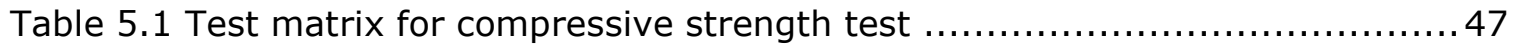

Table 5.2 Compressive strength values for Mix-1 (coarser fraction) ..................50

Table 5.3 Compressive strength values for Mix-2 (finer fraction) $\ldots \ldots \ldots \ldots \ldots \ldots \ldots \ldots \ldots$

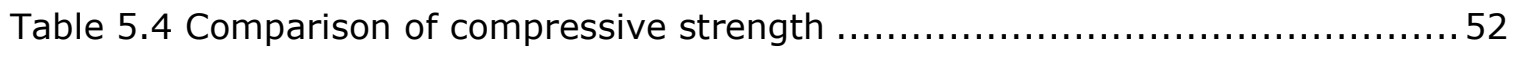

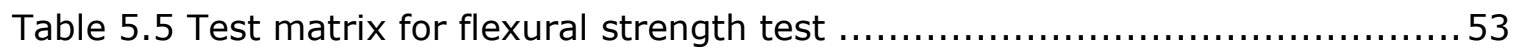

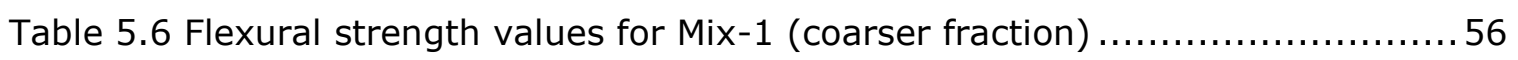

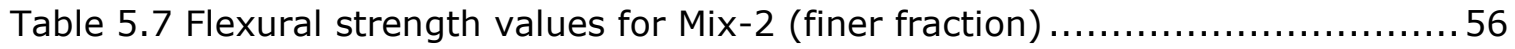

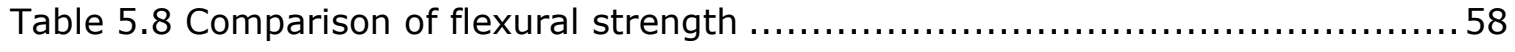

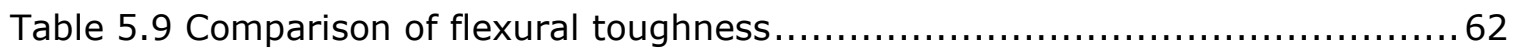

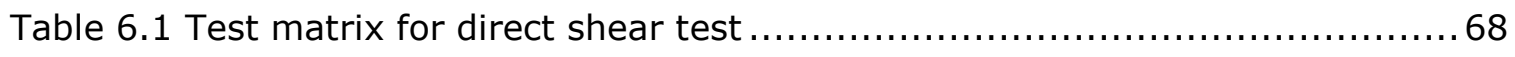

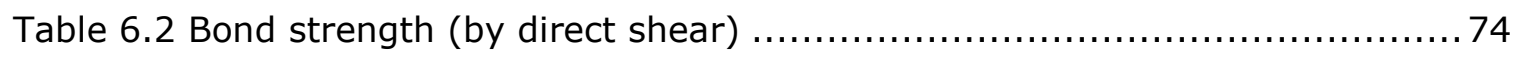

Table 6.3 Comparison of bond strength values (direct shear) $\ldots \ldots \ldots \ldots \ldots \ldots \ldots \ldots . \ldots 7$

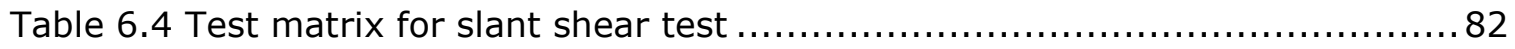

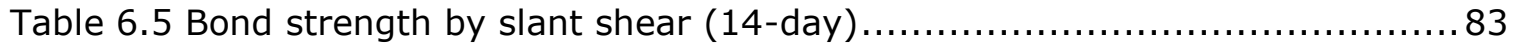

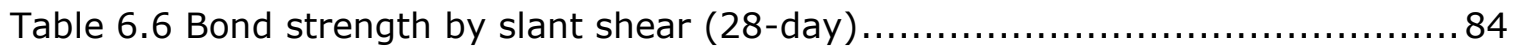

Table 6.7 Comparison of bond strength values (slant shear) $\ldots \ldots \ldots \ldots \ldots \ldots \ldots \ldots \ldots 7$

Table 6.8 Test matrix for pull-off test............................................ 91

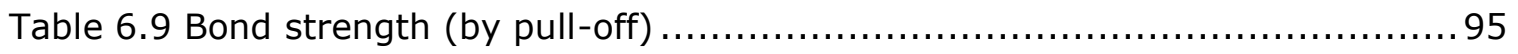


Table 6.10 Comparison of bond strength values (pull-off) $\ldots \ldots \ldots \ldots \ldots \ldots \ldots \ldots \ldots \ldots \ldots$

\section{APPENDICES}

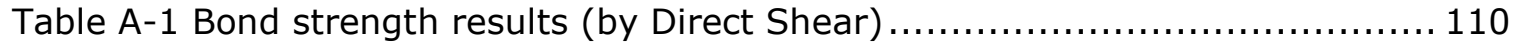

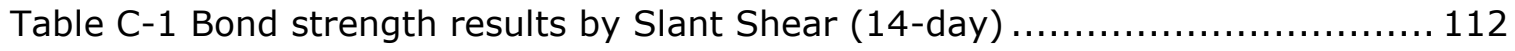

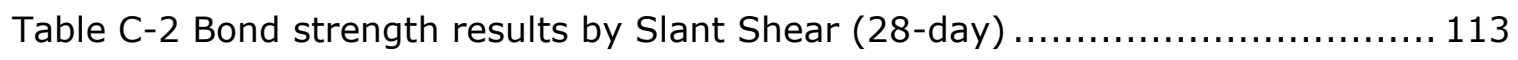

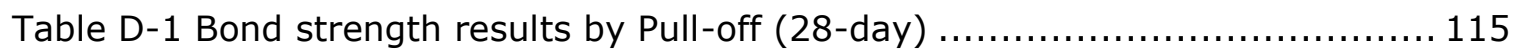




\section{LIST OF FIGURES}

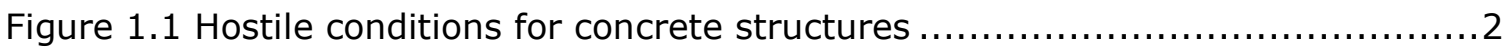

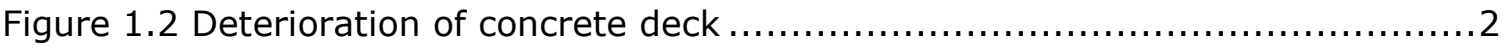

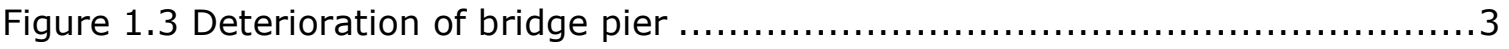

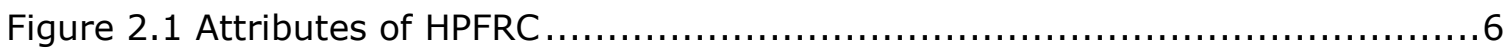

Figure 2.2 Classification of FRC composites (from Naaman and Reinhardt 2006) ......7

Figure 2.3 Load vs. deflection curves for unreinforced matrix and FRC (from ACI

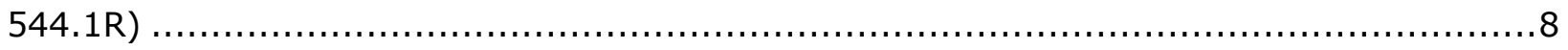

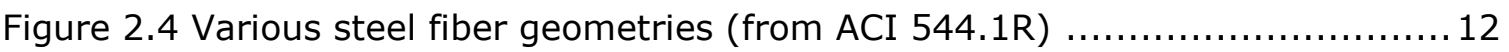

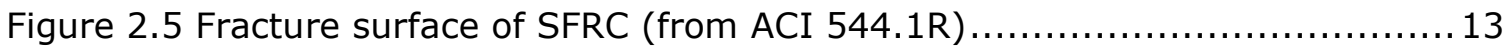

Figure 2.6 Relationship between slump, Vebe time \& Inverted Slump-cone time (from

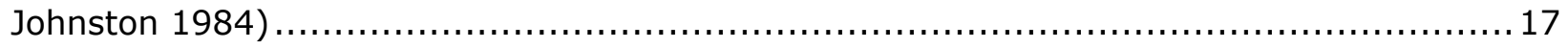

Figure 2.7 Toughness calculation by JSCE SF-4 method $\ldots \ldots \ldots \ldots \ldots \ldots \ldots \ldots \ldots \ldots \ldots \ldots \ldots \ldots \ldots \ldots \ldots \ldots \ldots$

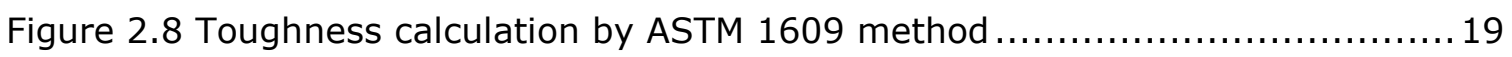

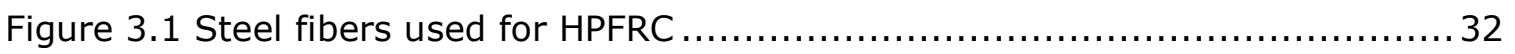

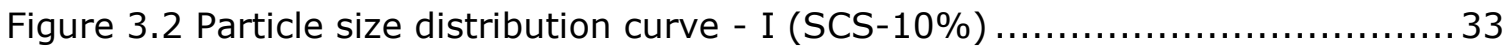

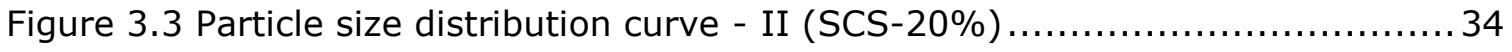

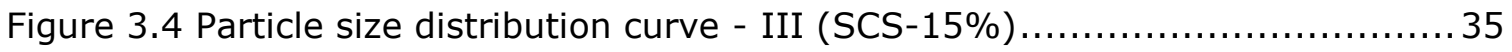

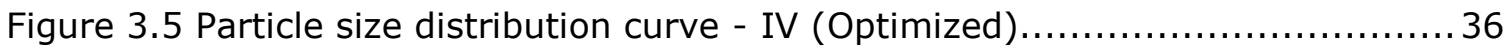

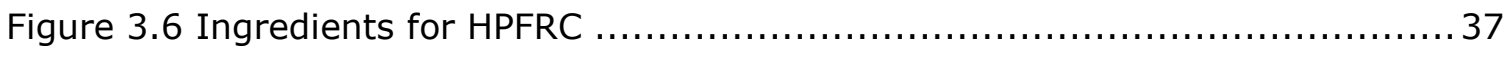

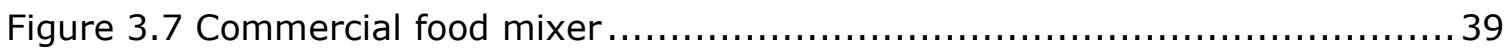

Figure 3.8 Fresh HPFRC Specimens covered with plastic sheet $\ldots \ldots \ldots \ldots \ldots \ldots \ldots \ldots . \ldots 40$ 


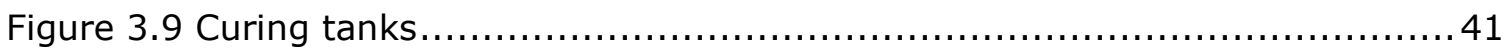

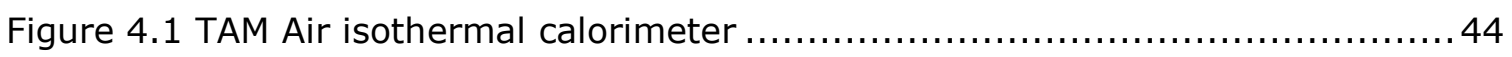

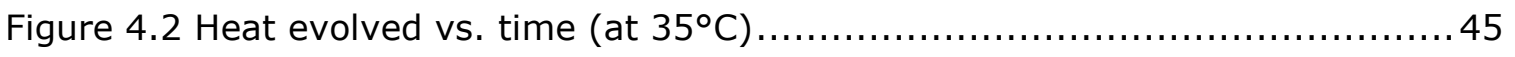

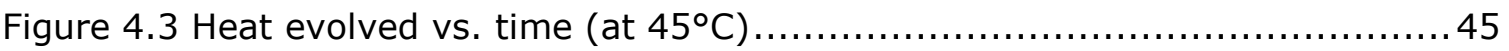

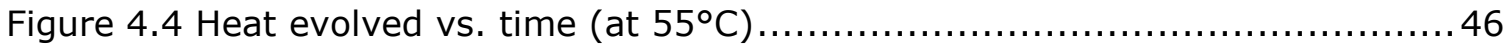

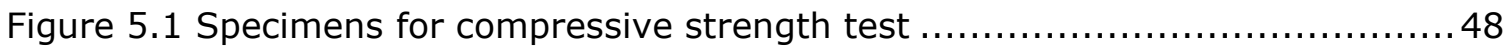

Figure 5.2 MTS machine used for compressive strength test $\ldots \ldots \ldots \ldots \ldots \ldots \ldots \ldots \ldots . \ldots \ldots$

Figure 5.3 Broken specimens (compressive strength test) $\ldots \ldots \ldots \ldots \ldots \ldots \ldots \ldots \ldots \ldots . \ldots 49$

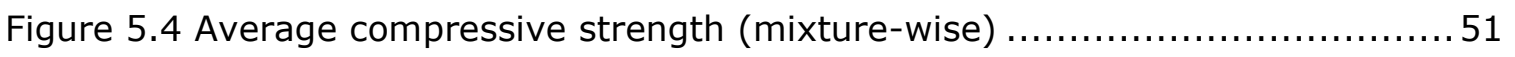

Figure 5.5 Average compressive strength (curing condition-wise) ................... 51

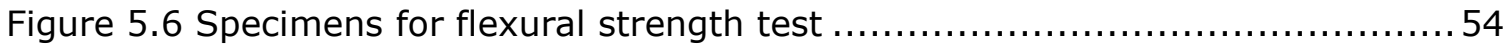

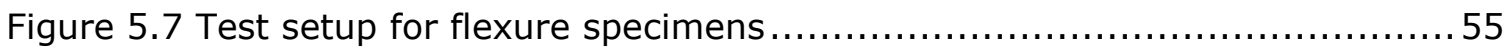

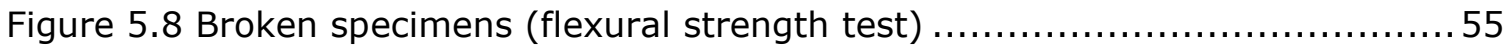

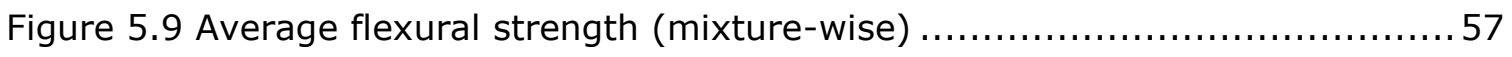

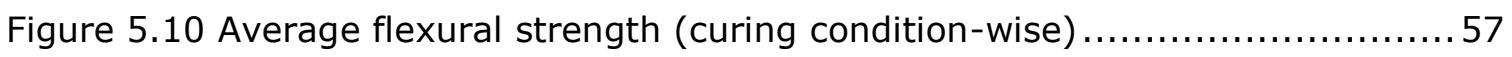

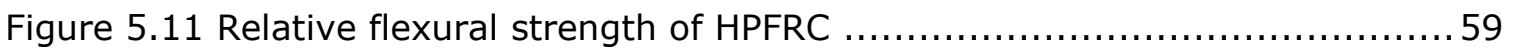

Figure 5.12 Typical load-deflection curve (before toe correction).$\ldots \ldots \ldots \ldots \ldots \ldots \ldots \ldots$

Figure 5.13 Typical load-deflection curve (after toe correction) $\ldots \ldots \ldots \ldots \ldots \ldots \ldots \ldots \ldots 1$

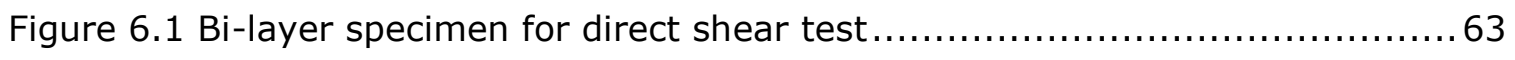

Figure 6.2 Schematic view of specimen with applied loads (from Sun 2004) .........64

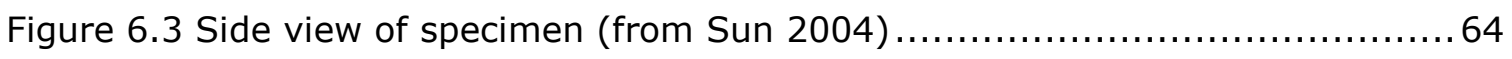

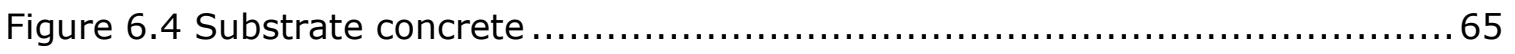


Figure 6.5 Mechanically prepared substrate surface

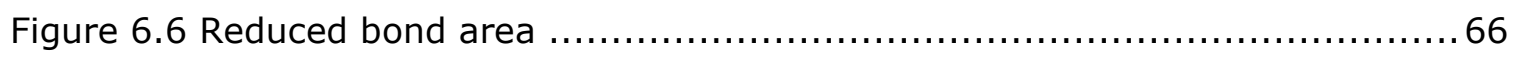

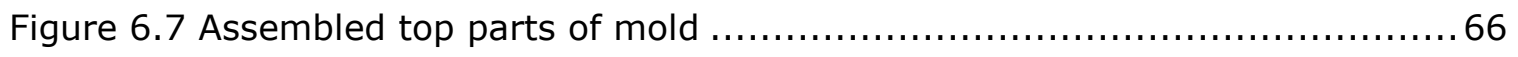

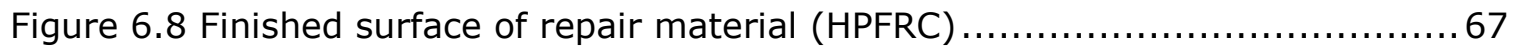

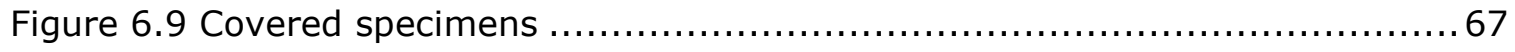

Figure 6.10 Shear testing apparatus (1) used by (Luo 2002) [from Sun 2004] .......68

Figure 6.11 Shear testing apparatus (2) used by (Luo 2002) [from Sun 2004] .......69

Figure 6.12 Modified shear testing apparatus used by (Sun 2004$) \ldots \ldots \ldots \ldots \ldots \ldots \ldots . \ldots . \ldots . \ldots . \ldots$

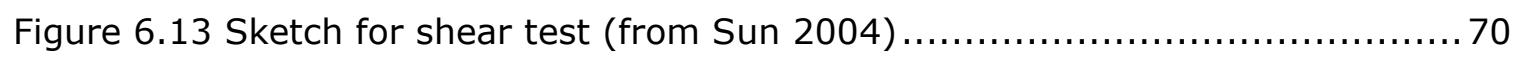

Figure 6.14 Failure surfaces of the test specimens (representative) $\ldots \ldots \ldots \ldots \ldots \ldots . \ldots 1$

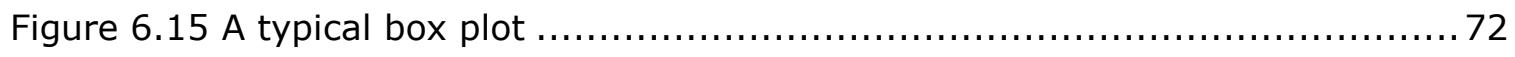

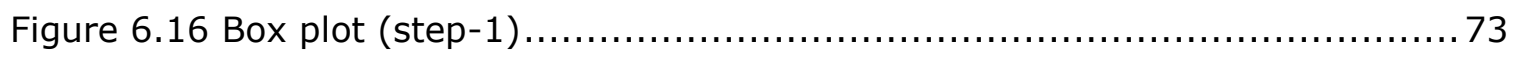

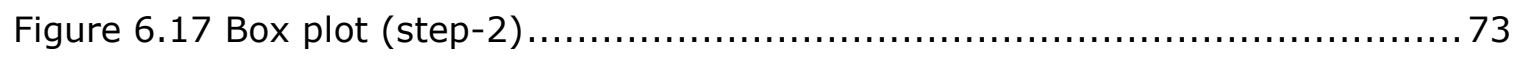

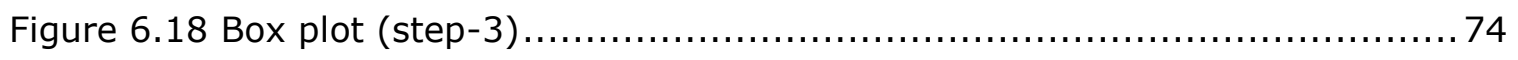

Figure 6.19 Bond strength by direct shear (curing condition-wise) $\ldots \ldots \ldots \ldots \ldots \ldots \ldots . \ldots \ldots$

Figure 6.20 Bond strength by direct shear (surface treatment-wise) $\ldots \ldots \ldots \ldots \ldots \ldots \ldots . \ldots \ldots$

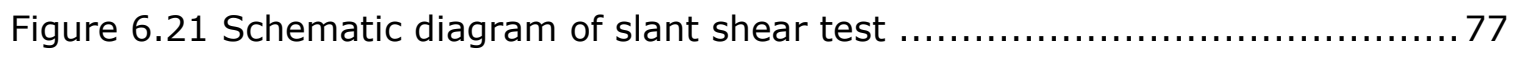

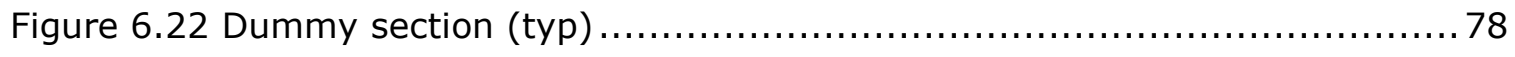

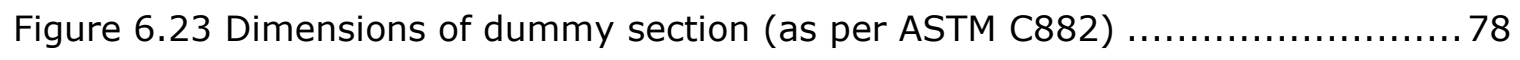

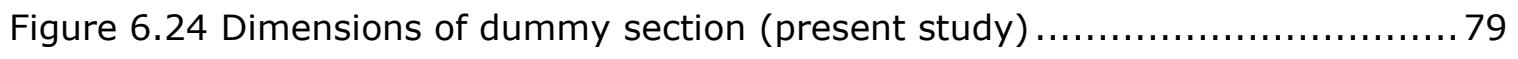

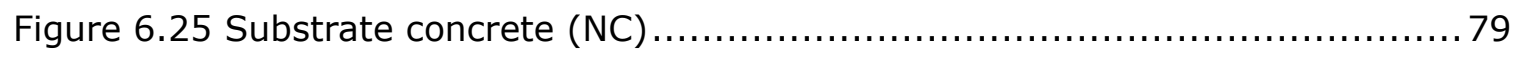

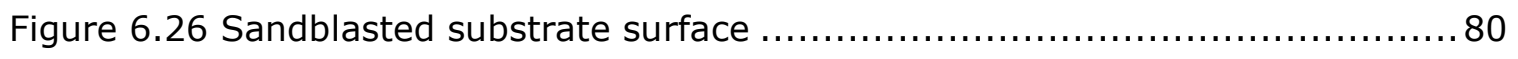


Figure 6.27 Mold ready for repair casting 80

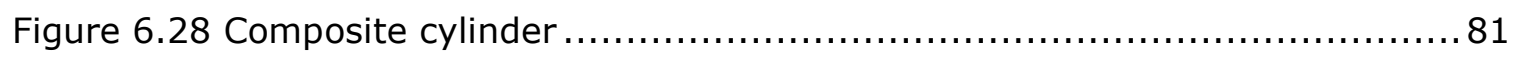

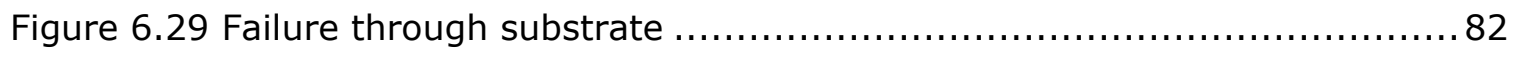

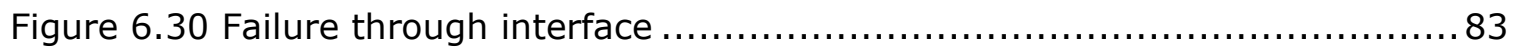

Figure 6.31 14-day bond strength by slant shear (curing condition-wise) ............84

Figure 6.32 28-day bond strength by slant shear (curing condition-wise) ............. 85

Figure 6.3314 -day bond strength by slant shear (surface treatment-wise) $\ldots \ldots \ldots . . . .86$

Figure 6.3428 -day bond strength by slant shear (surface treatment-wise) ..........86

Figure 6.35 Schematic diagram of pull-off test (from ASTM 1583) ................. 88

Figure 6.36 Different types of failure modes in pull-off test (from ASTM 1583) .......88

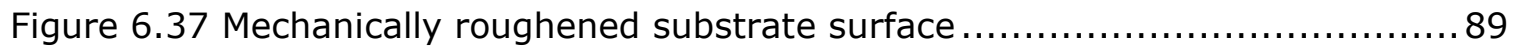

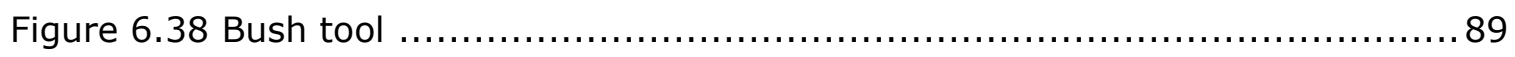

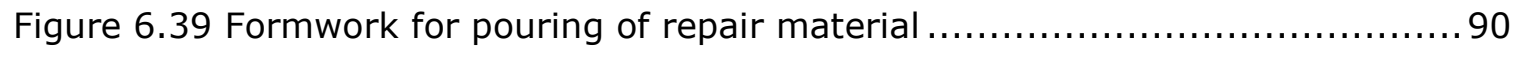

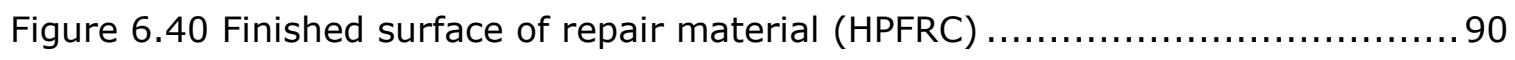

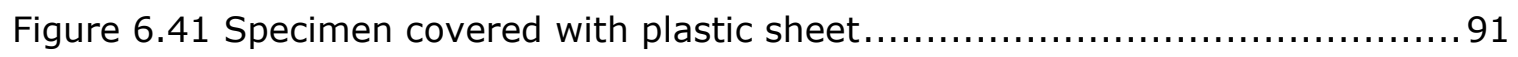

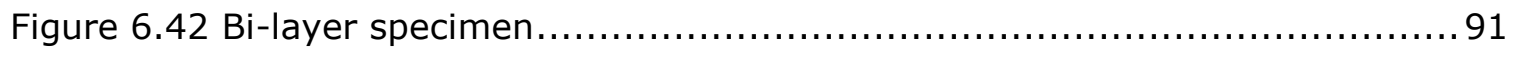

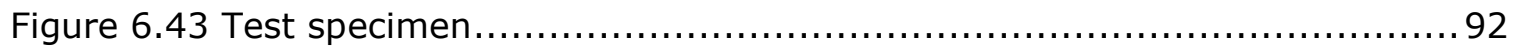

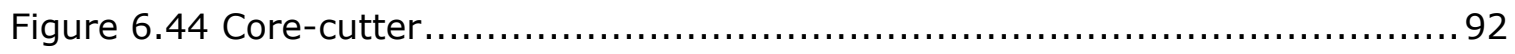

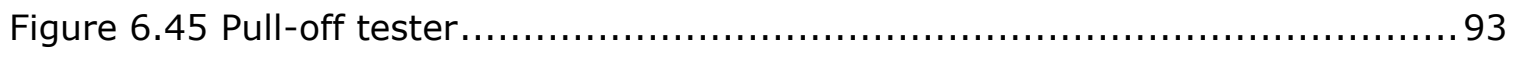

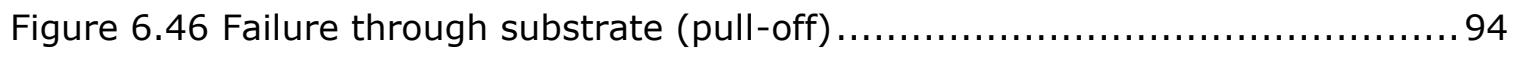

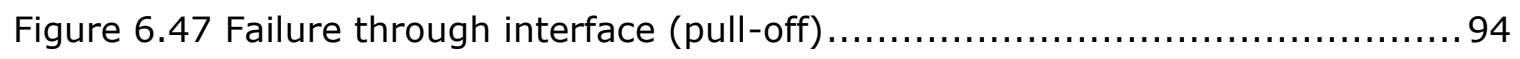

Figure 6.48 Average bond strength by pull-off (curing condition-wise) ............... 95 
Figure 6.49 Average bond strength by pull-off (surface treatment-wise)

Figure 6.50 Comparison of bond strength by different tests $\ldots \ldots \ldots \ldots \ldots \ldots \ldots \ldots \ldots . \ldots \ldots$ 


\section{ABBREVIATIONS}

\begin{tabular}{|c|c|}
\hline ACI & American Concrete Institute \\
\hline ARGFRC & Alkali Resistant Glass Fiber Reinforced Concrete \\
\hline ASTM & American Society for Testing and Materials \\
\hline CFRC & Carbon Fiber Reinforced Concrete \\
\hline CSP & Concrete Surface Profile \\
\hline ECC & Engineered Cementitious Composites \\
\hline FRC & Fiber Reinforced Concrete \\
\hline GFRC & Glass Fiber Reinforced Concrete \\
\hline HPC & High Performance Concrete \\
\hline HPFRC & High Performance Fiber Reinforced Concrete \\
\hline HPFRCC & High Performance Fiber Reinforced Cement Composites \\
\hline HSC & High Strength Concrete \\
\hline ICRI & International Concrete Repair Institute \\
\hline LMC & Latex Modified Concrete \\
\hline NC & Normal Concrete \\
\hline NFRC & Natural Fiber Reinforced Concrete \\
\hline SFMC & Silica Fume Modified Concrete \\
\hline SFRC & Steel Fiber Reinforced Concrete \\
\hline SNFRC & Synthetic Fiber Reinforced Concrete \\
\hline UHPC & Ultra High Performance Concrete \\
\hline
\end{tabular}




\section{CHAPTER 1 INTRODUCTION}

This introductory chapter presents background information on high performance fiber reinforced concrete (HPFRC). It also describes the motivation, goal, tasks, significance of the present research, and the organization of the thesis.

\subsection{Background of HPFRC}

ACI 544.1R (Report on Fiber Reinforced Concrete) defines fiber reinforced concrete (FRC) as a "concrete made primarily of hydraulic cements, aggregates, and discrete reinforcing fibers".

Normal concrete (NC) without any reinforcement, by virtue of its brittle nature, shows no significant post-cracking ductility. Fibers are added to NC in order to bridge across the cracks as they begin to open once the concrete matrix has cracked. In a nutshell, fibers provide the post-cracking ductility to the material.

HPFRC can be defined as a special class of FRC, which exhibits high compressive strength, high flexural strength, high ductility, high modulus of elasticity, and high durability.

HPFRC is a product which is similar to high performance fiber reinforced cement composites (HPFRCC) and engineered cementitious composites (ECC) but not exactly the same.

\subsection{Motivation for the Current Research}

Concrete is the most ubiquitous construction material in the world. In terms of its utilization, it is second only to water. Annually, 6 billion tons of concrete is produced in the world and the US consumption of concrete is over 2.5 tons a year per person (Roadmap 2030). It drives a US $\$ 100$ billion industry in the United States alone employing over 2 million people. It enjoys huge acceptability over other construction materials, such as, steel, wood, across the globe.

Though concrete is strong and durable, it does not last forever, especially when exposed to aggressive conditions. Deicing salts, freeze-thaw cycles, high heat, high mechanical loading, seismic events, etc. lead to potential deterioration of the concrete 
structure. As a consequence, the service life of the structure is reduced. Typical causes for service life reduction of concrete structures are shown in Figure 1.1.

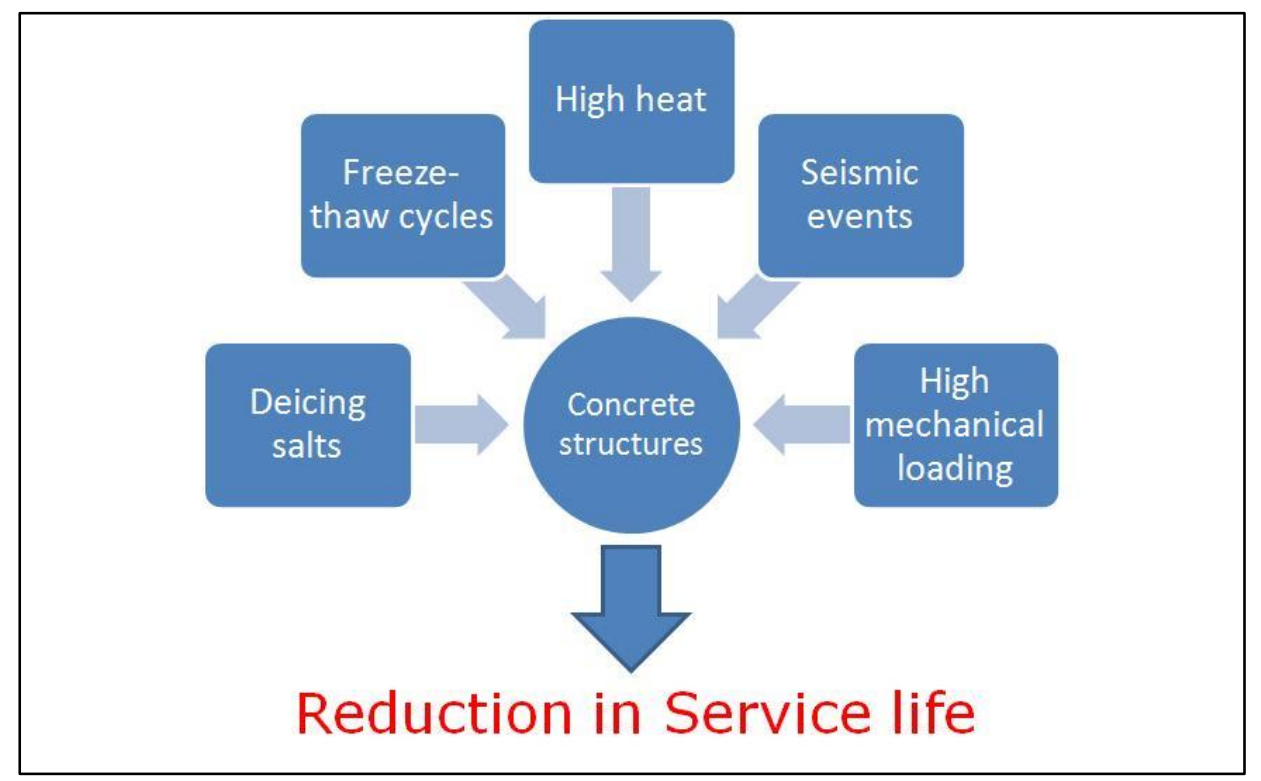

Figure 1.1 Hostile conditions for concrete structures

In US, 1 in every 4 bridges is either structurally deficient or functionally obsolete. The nation's crumbling infrastructures and buildings need urgent replacement. The replacement cost of these structures being enormous, there is a pressing need, more than ever, for repairing and rehabilitating these deficient structures. Figure 1.2 and Figure 1.3 show deterioration of concrete structures by deicing salts.

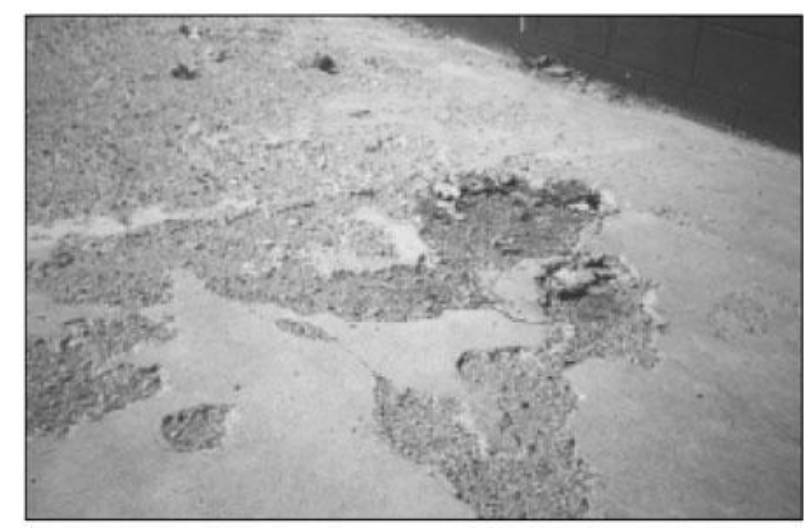

Figure 1.2 Deterioration of concrete deck

(Picture source: http://www.nrc-cnrc.gc.ca/eng/ibp/irc/ctus/ctus-n59.html) 


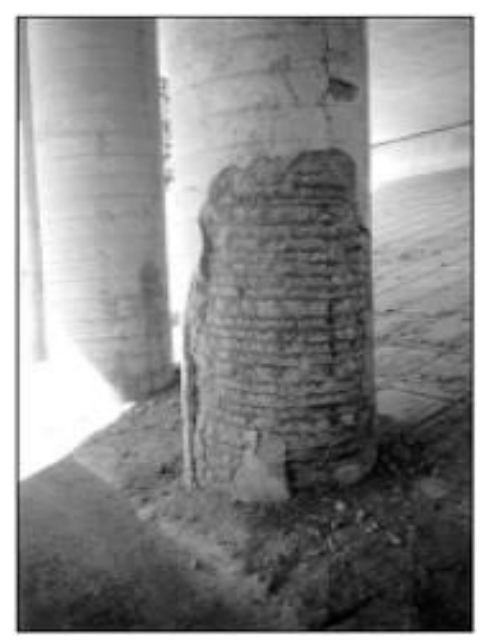

Figure 1.3 Deterioration of bridge pier

(Picture source: http://www.nrc-cnrc.gc.ca/eng/ibp/irc/ctus/ctus-n59.html)

Keeping the above points in mind, the present study focused on developing state-ofthe-art HPFRC material with very high strength, improved ductility, and good bond property, which can be used to rehabilitate the deteriorated structures by repairing them at a fraction of total replacement cost.

\subsection{Goal of the Research}

The goal of the present study is to develop HPFRC repair material using commercially available raw materials from US market with the following attributes:
a. High compressive strength
b. High flexural strength
C. High ductility and energy absorption capacity
d. Good bonding property

\subsection{Tasks}

The following tasks were performed in order to achieve the above goal.

a. Selection of raw materials and design of mixture proportions by optimizing particle size distribution of fine aggregates.

b. Development of mixing procedure for a homogeneous and workable concrete mix. 
c. Selection of different curing conditions to ascertain the effect of curing temperature on the hardened properties of HPFRC.

d. Determination of rate of hydration reaction of HPFRC mix by performing isothermal calorimetry test.

e. Evaluation of compressive strength, flexural strength, and flexural toughness of HPFRC.

f. Selection of the best performing mixture proportion and curing condition, based on the results of compressive and flexural strength tests, for further bond study.

g. Evaluation of bond strength between HPFRC and NC by direct shear, slant shear, and pull-off tests.

h. Conclusions and recommendations for future work.

\subsection{Research Significance}

The present study will address the issue of essential need of repairing and rehabilitation of the crumbling infrastructures in the United States by developing state-ofthe-art HPFRC repair material.

HPFRC is an engineered cementitious material with high strength, improved ductility, high durability, and good bond property. Although there are many potential benefits of HPFRC, previous studies in this field have noted some concerns about HPFRC, which require attention. Some of the concerns are listed below:

a. Proper selection of materials and their relative proportions

b. Possible loss of workability due to finer particles and addition of discrete fibers

c. Low water to cementitious materials ratio in order to achieve a high strength matrix

d. Different mixing procedure compared to NC

e. Proper surface preparation of the substrate when HPFRC is used as a repairing material

f. Possible increased shrinkage and cracking risk due to high finer content

In the present research, emphasis is given on the first five points mentioned above. Though several studies have been conducted on material characterization of HPFRC, very limited studies have been done on evaluation of bond property of HPFRC. Hence, the current research focuses on an in-depth study of the bond behavior of HPFRC for its use as a repairing material. 


\subsection{Thesis Organization}

This thesis is organized into seven chapters as follows:

Chapter 1: A brief introduction about HPFRC along with the motivation, goal, tasks, significance of the present research, and the organization of the thesis are presented in this introductory chapter.

Chapter 2: This chapter presents a detailed literature review on various aspects of HPFRC.

Chapter 3: The materials and the mixture proportions that were used to develop HPFRC and NC are described in this chapter.

Chapter 4: This chapter describes the isothermal calorimetry test performed on the HPFRC mortars.

Chapter 5: This chapter presents the determination of hardened properties of HPFRC.

Chapter 6: Bond properties of HPFRC are evaluated in this chapter.

Chapter 7: This chapter summarizes the key findings of the research and gives suggestions for future work. 


\section{CHAPTER 2 BACKGROUND AND LITERATURE REVIEW}

This chapter presents a review of background information and different stages of development of HPFRC over the years.

\subsection{Definition of HPFRC}

ACI 544.1R (Report on Fiber Reinforced Concrete) defines fiber reinforced concrete (FRC) as a 'concrete made primarily of hydraulic cements, aggregates, and discrete reinforcing fibers'. Different types of fibers are used to produce various kinds of FRC. The most common types of fibers are produced from steel, glass, carbon, and organic polymers (synthetic fibers). Naturally occurring asbestos fibers and organic fibers are also used as reinforcement. Normally, the length and diameter of the fibers for producing FRC do not exceed $76 \mathrm{~mm}$ (3 in.) and $1 \mathrm{~mm}$ (0.04 in.), respectively (ACI 544.1R). The concrete matrix in FRC may be mortar, normal concrete or special type of mix (such as, self-consolidating concrete) depending on the intended use of the final product.

HPFRC is a special class of FRC, which exhibits high compressive and flexural strength, high ductility and energy absorption capacity, high modulus of elasticity, and high durability. The attributes are shown in Figure 2.1.

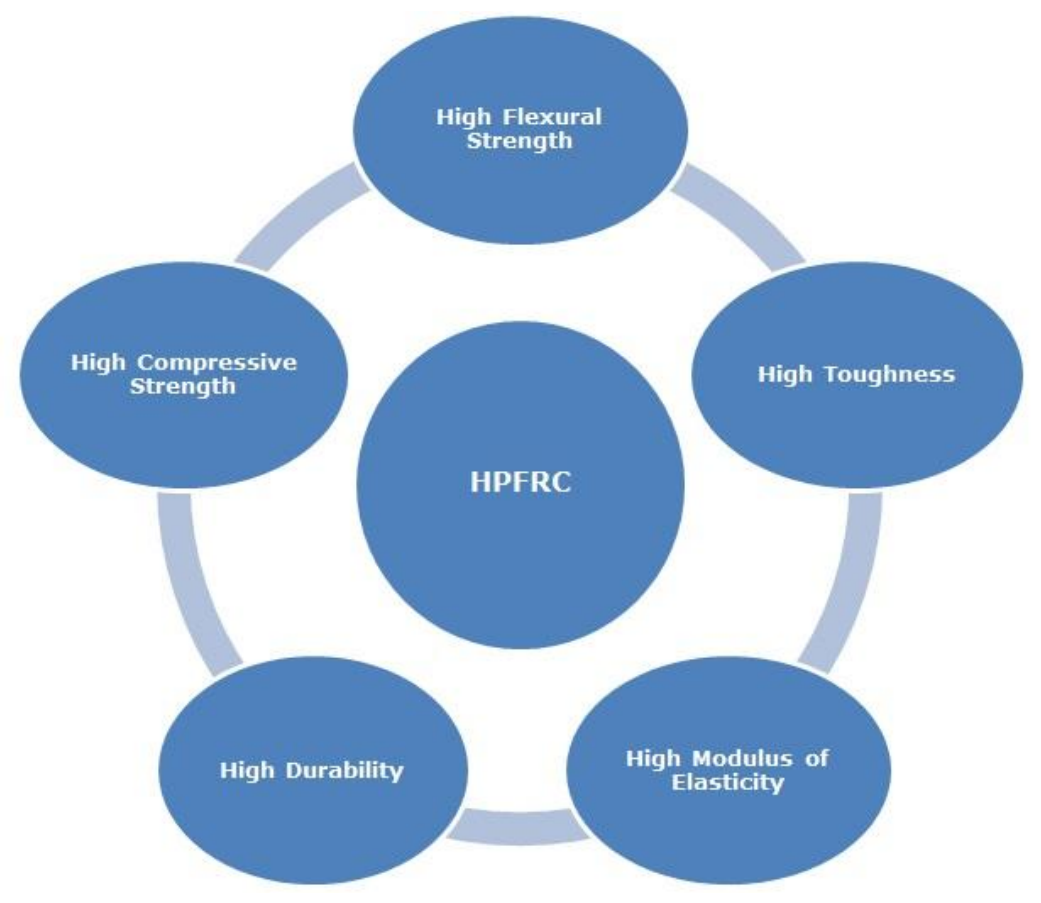

Figure 2.1 Attributes of HPFRC 
HPFRC has superior flexural strength and much improved ductility compared to conventional FRC. When loaded in flexure, it shows deflection hardening behavior after first crack. The load after first crack increases with deflection and multiple cracking occurs until the load reaches the maximum value (peak load). Deflection softening starts after the peak load and the load decreases with the increase in deflection.

The classification of FRC based on stress-strain response in tension, namely, tensile strain hardening FRC and tensile strain softening FRC and further classification of tensile strain softening FRC into deflection hardening FRC and deflection softening FRC are explained elsewhere (Naaman and Reinhardt 2006). Figure 2.2 shows the classification of FRC based on tensile stress-strain response.

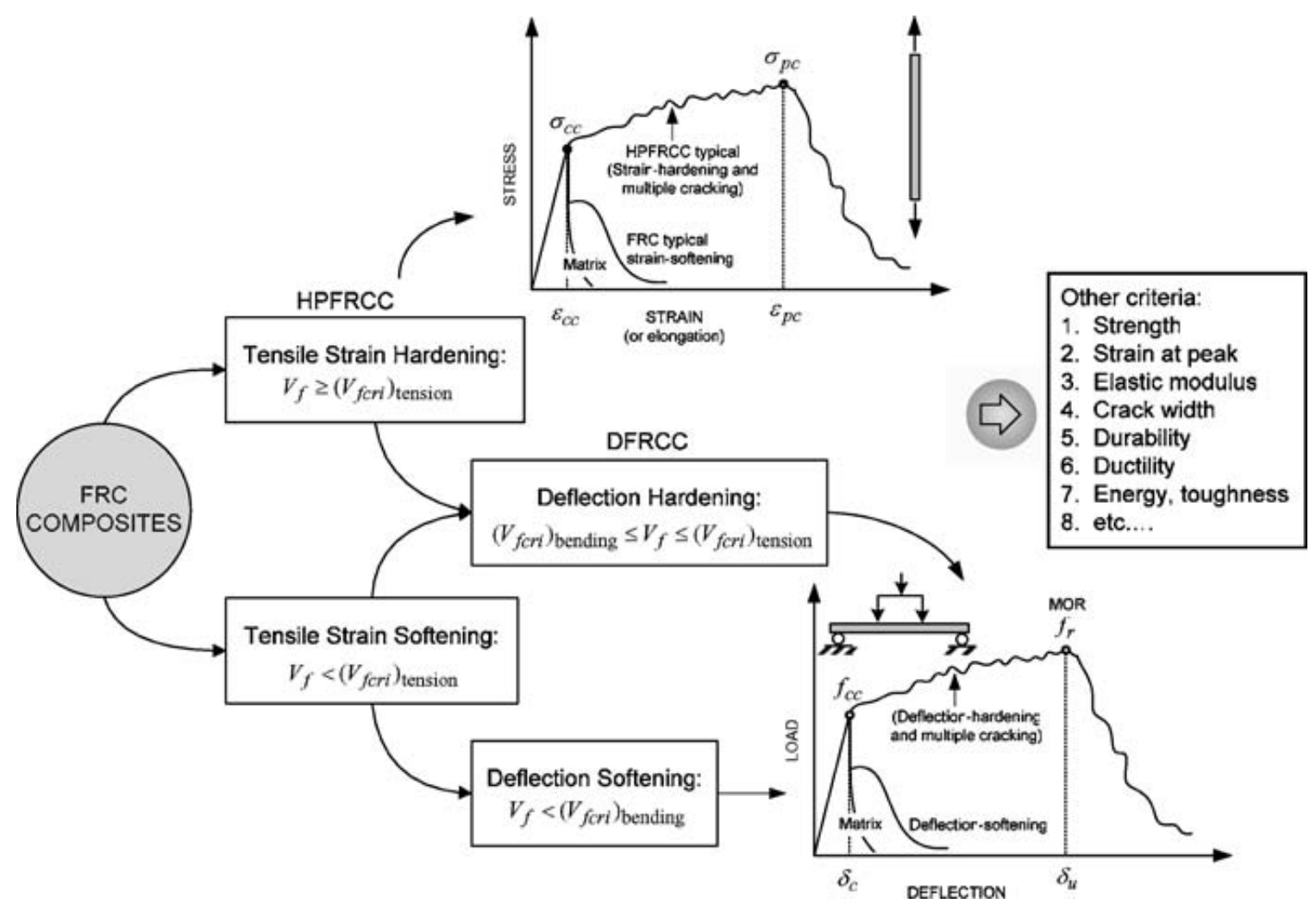

Figure 2.2 Classification of FRC composites (from Naaman and Reinhardt 2006)

HPFRC has flexural strength similar to high performance fiber reinforced cementitious composites (HPFRCC) and engineered cementitious composites (ECC) and much higher than deflection hardening FRCC (DHFRCC) and high performance concrete (HPC). Its compressive strength is superior to that of HPC, DHFRCC, ECC, and HPFRCC but is lower than ultra high performance concrete (UHPC). It has better bonding property than latex modified concrete (LMC) and conventional FRC. 
ECC is another special class of FRCC with superior ductile property (Li 2003). It also strain-hardens rather than strain-softens after first cracking ( $\mathrm{Li}$ and Kanda 1998). This high ductility is achieved by tailoring the micromechanical parameters of the constituents, namely, the fibers, the matrix, and the fiber-matrix interface (Li and Leung 1992, Li 1993, and Kanda and Li 1999).

\subsection{Advantages of HPFRC}

The most fundamental mechanical property difference between normal concrete (NC) and HPFRC is the superior ductile property exhibited by HPFRC. NC without any reinforcement, by virtue of its brittle nature, shows no significant post-cracking ductility. Fibers are added to normal concrete in order to bridge across the cracks as they begin to open once the concrete matrix has cracked. In a nutshell, fibers provide the post-cracking ductility to the material. Load vs. deflections curves for unreinforced matrix and FRC are shown in Figure 2.3.

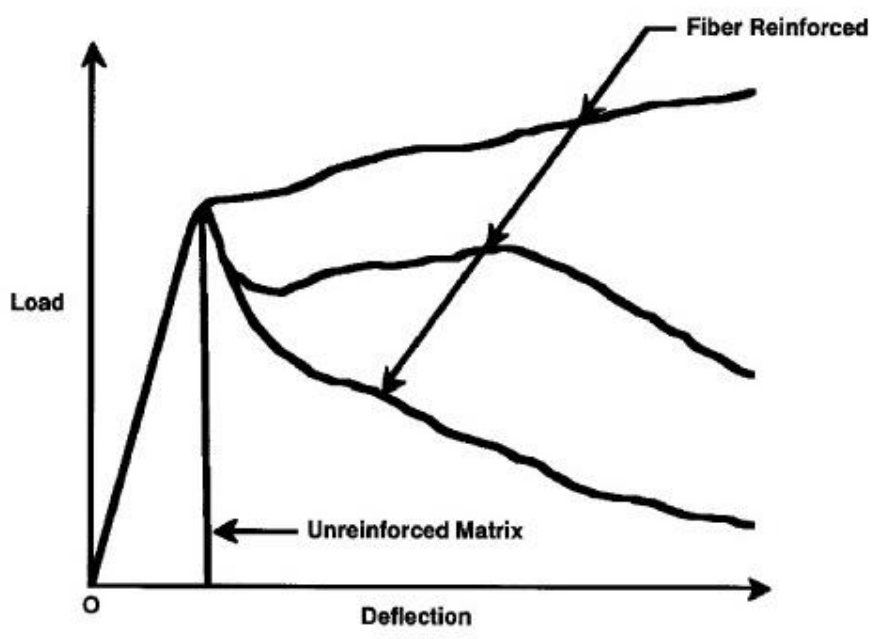

Figure 2.3 Load vs. deflection curves for unreinforced matrix and FRC (from ACI 544.1R)

The magnitude of these post-elastic property changes depends upon type of matrix, strength of matrix, size of aggregates, type of fiber, fiber content, fiber aspect ratio, strength and modulus of fiber, fiber orientation, and surface bonding characteristic of fiber.

Other advantages of HPFRC are the superior compressive and flexural strength, high modulus of elasticity, high durability, and low permeability. 


\subsection{History and Development of HPFRC}

Use of fibers to strengthen otherwise brittle building materials, dates back to ancient times. Historically, straw was used to reinforce sun-dried mud bricks (adobe) and horse hair was used to reinforce masonry mortar and plaster. In case of adobe, such reinforcement used to make the resulting product better resistant to cracking and subsequently, better resistant to fragmentation after cracking was induced by repetitive changes in temperature and humidity (Namaan 1985). The Romans used to add horse hair in concrete in order to make it less liable to cracks.

In 1847, Joseph Lambot patented a new building material by adding continuous fibers in the form of wires or wire meshes to concrete (Namaan 1985). That product led to the development of ferrocement, as it is known today. The higher labor cost in placing continuous fibers led to the quest of discontinuous fibers that could be added to the mixer like aggregates or admixtures.

The idea of A. Berard to use discontinuous fibers in the form of granular waste iron in concrete mix was the first registered patent (1874) on FRC (Namaan 1985). Many patents on various kinds of fibers were registered in different countries in the following years.

Asbestos fibers were first used in cement matrix in early 1900. Since then asbestos based cemenititious products have been widely used in the construction industry throughout the world. However, the discovery of the associated health risks with asbestos fibers mandated the use of alternative fibers. By the 1960s, steel, glass, and other synthetic fibers were used in concrete and the search for new fibers continues even today.

Glass fibers were first used in concrete in the late 1950s (Biryukovich 1965). Since ordinary glass fibers were not alkali-resistant, they were not suitable for highly alkaline portland cement medium. Later, Majumdar and Ryder (1968) invented alkali-resistant (AR) glass fibers with the addition of zircon oxide $\left(\mathrm{ZrO}_{2}\right)$.

Krenchel and Shah (1985) reported that polypropylene fibers were used in concrete as early as 1970 in England, but the performance of the resulting cement composite was not as good as that of concrete reinforced with steel and glass fibers. The main reasons behind the poor performance were the relatively lower elastic modulus of polypropylene fibers and the inferior bond between cement matrix and the ordinary polypropylene fibers. Later, an improved polypropylene fiber having higher elastic modulus and tensile strength and better bonding characteristic was developed in Denmark (Krenchel and Shah 1985). 
Since mid-1960s, substantial progress in the field of FRC has been made possible due to the following advances in cement and concrete industry (Naaman 2007):

a. Commercial introduction of new generation superplasticizers,

b. Increasing use of active or inactive micro-fillers, such as, silica fume and fly ash and a better understanding of their effect on matrix porosity, strength, and durability,

c. Increasing availability of different types of fibers for use in concrete, which can add significantly to the strength, ductility, and toughness of the resulting composite,

d. Use of polymer addition or impregnation of concrete for better bonding between fibers and matrix, and

e. Innovations in production processes (such as self-consolidation or selfcompacting) to improve uniform mixing of high volumes of fiber with reduced effects on the porosity of the matrix.

Substantial progress has also been made in modeling the behavior of FRC (Balaguru and Shah 1992, Bentur and Mindess 1990, Brandt et al. 2000, Hannant 1978, and Karihaloo 1997).

The above factors have led to the development of 'high performance fiber reinforced cement composite' as it is known today.

\subsection{Relevant Terminology}

Some terms, relevant to the present study, are discussed below in accordance with ACI 544.1R.

\subsubsection{Aspect Ratio}

The aspect ratio is defined as the ratio of length to diameter of the fiber.

\subsubsection{Balling}

When fibers entangle into large clumps or balls in a mixture, the phenomenon is called balling.

\subsubsection{Fiber Count}

Fiber count is defined as the number of fibers in a unit volume of concrete matrix. 


\subsubsection{First Crack}

First crack is the point on the flexural load-deflection or tensile load-extension curve at which the form of the curve first becomes nonlinear.

\subsubsection{First Crack Strength}

The stress corresponding to the load at "First Crack" (explained above) in bending or tension is called the first crack.

\subsubsection{Flexural Toughness}

Flexural toughness is the area under the flexural load-deflection curve obtained from a static test of a specimen up to a specified deflection. It is an indication of the energy absorption capability of a material.

\subsubsection{Modulus of Rupture (MOR)}

MOR is the greatest bending stress attained in a flexural strength test of a fiber reinforced concrete specimen. Although modulus of rupture is synonymous with matrix cracking for plain concrete specimens, this is not the case for fiber reinforced concrete specimens.

\subsection{Types of Fiber Reinforced Concrete}

Based on fiber type, FRC is divided into four basic categories (ACI 544.1R), namely, a) Steel Fiber Reinforced Concrete (SFRC), b) Glass Fiber Reinforced Concrete (GFRC), c) Synthetic Fiber Reinforced Concrete (SNFRC), and d) Natural Fiber Reinforced Concrete (NFRC). Each of the above types is described in the subsequent paragraphs.

\subsubsection{Steel Fiber Reinforced Concrete (SFRC)}

SFRC is concrete made of hydraulic cement and fine or fine and coarse aggregate and discontinuous discrete steel fibers. The fibers are short, having an aspect ratio that varies from 20 to 100 .

According to ASTM A820, steel fibers are categorized into four general types based on the product used in their manufacture:

i) Type I-Cold-drawn wire

ii) Type II-Cut sheet 
iii) Type III-Melt-extracted

iv) Type IV-Other fibers

Steel fibers are available in different shapes. The various steel fiber geometries are shown in Figure 2.4.

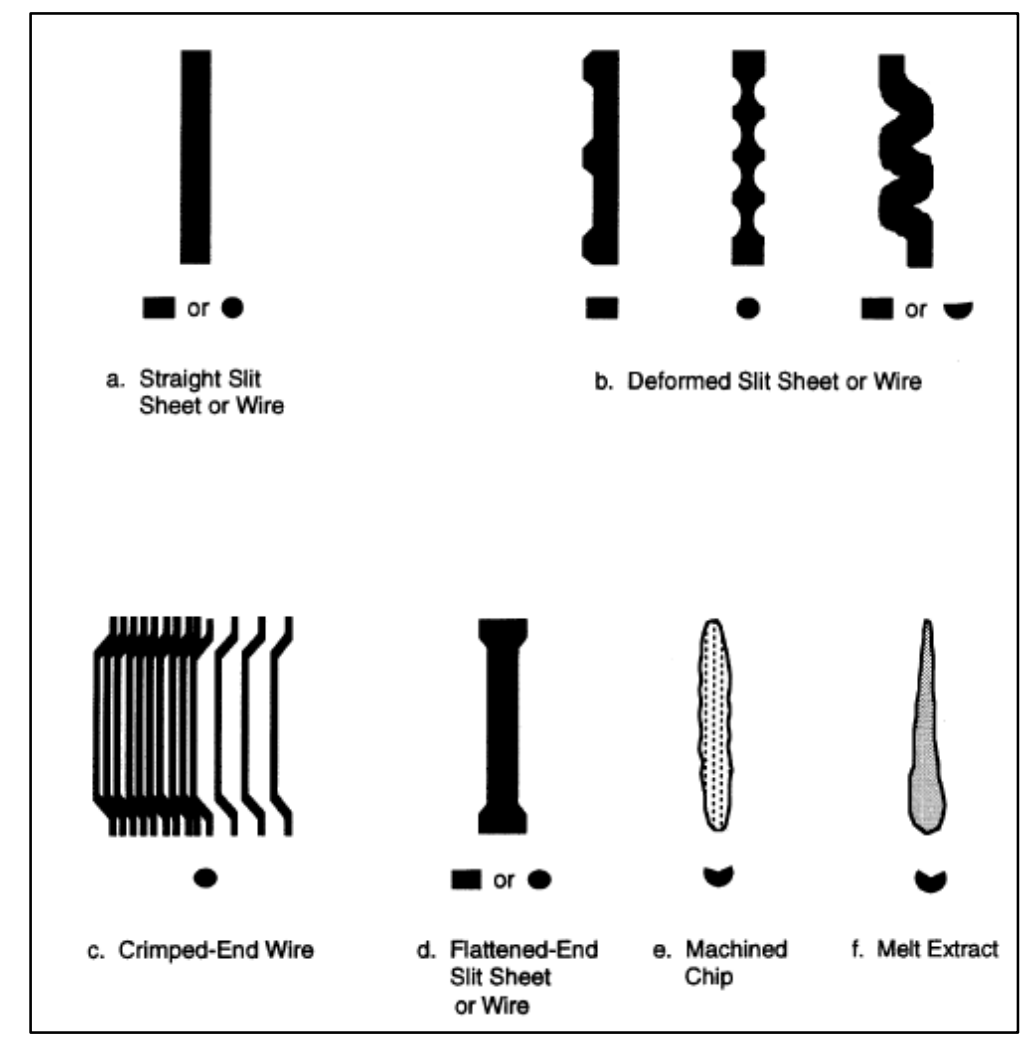

Figure 2.4 Various steel fiber geometries (from ACI 544.1R)

Steel fibers are generally composed of carbon steel or stainless steel, depending on the intended application of the SFRC. For example, in high temperature refractory applications, stainless steel fibers are generally used in producing the SFRC.

In tension, SFRC fails only after the steel fiber breaks or is pulled out of the cement matrix. Typical fracture surface of SFRC is shown in Figure 2.5. 


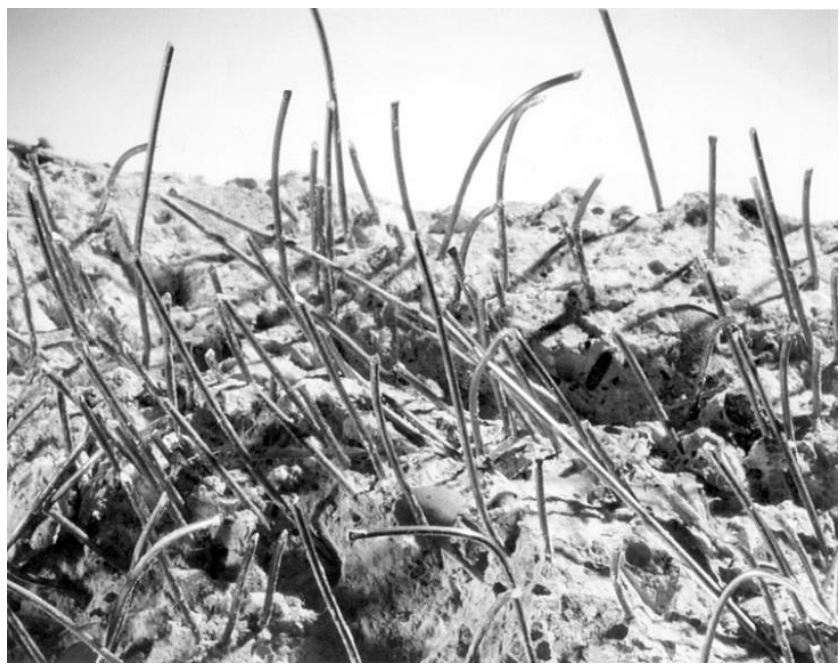

Figure 2.5 Fracture surface of SFRC (from ACI 544.1R)

\subsubsection{Glass Fiber Reinforced Concrete (GFRC)}

GFRC uses glass fibers that are produced from molten glass. These fibers are available both as chopped strand and as continuous roving.

In the early 1960s, conventional borosilicate glass fibers (E-glass) and soda-limesilica glass fibers (A-glass) were used to reinforce the concrete matrix. Since these glass fibers were not alkali-resistant, they used to lose strength very fast in the highly alkaline $\left(p^{H} \geq 12.5\right)$ cement-based medium. Hence, GFRC reinforced with E-glass and A-glass fibers were not suitable for long term use.

Alkali-resistant (AR) glass containing 16 percent zirconia was first produced in the United Kingdom Building Research Establishment (BRE) in 1967. Subsequently, AR glass with different zirconia contents were produced in other countries. In modern times, ARGFRC is the most widely used system for the manufacture of GFRC products.

Chemical composition and physical properties of E-glass, A-glass, and different types of AR-glass are shown in Table 2.1 and Table 2.2, respectively. 
Table 2.1 Chemical composition of different glass fibers (from ACI 544.1R)

\begin{tabular}{c|c|c|c|c}
\hline Component & A-glass & E-glass & Cem-FIL AR-glass & NEG AR-glass \\
\hline $\mathrm{SiO}_{2}$ & 73.0 & 54.0 & 62.0 & 61.0 \\
\hline $\mathrm{Na}_{2} \mathrm{O}$ & 13.0 & - & 14.8 & 15.0 \\
\hline $\mathrm{CaO}$ & 8.0 & 22.0 & - & - \\
\hline $\mathrm{MgO}$ & 4.0 & 0.5 & - & - \\
\hline $\mathrm{K}_{2} \mathrm{O}$ & 0.5 & 0.8 & - & 2.0 \\
\hline $\mathrm{Al}_{2} \mathrm{O}_{3}$ & 1.0 & 15.0 & 0.8 & - \\
\hline $\mathrm{Fe}_{2} \mathrm{O}_{3}$ & 0.1 & 0.3 & - & - \\
\hline $\mathrm{B}_{2} \mathrm{O}_{3}$ & - & 7.0 & - & - \\
\hline $\mathrm{ZrO}_{2}$ & - & - & 16.7 & 20.0 \\
\hline $\mathrm{TiO}_{2}$ & - & - & 0.1 & - \\
\hline $\mathrm{Li}_{2} \mathrm{O}$ & - & - & - & 1.0 \\
\hline
\end{tabular}

Table 2.2 Physical properties of different glass fibers (from ACI 544.1R)

\begin{tabular}{l|c|c|c|c}
\hline \multicolumn{1}{c|}{ Property } & A-Glass & E-Glass & Cem-FIL AR-Glass & NEG AR-Glass \\
\hline Specific gravity & 2.46 & 2.54 & 2.70 & 2.74 \\
Tensile strength, ksi & 450 & 500 & 360 & 355 \\
Modulus of elasticity, ksi & 9400 & 10,400 & 11,600 & 11,400 \\
Strain at break, percent & 4.7 & 4.8 & 3.6 & 2.5 \\
\hline
\end{tabular}

Metric equivalent: $1 \mathrm{ksi}=1000 \mathrm{psi}=6.895 \mathrm{MPa}$

\subsubsection{Synthetic Fiber Reinforced Concrete (SNFRC)}

SNFRC is concrete reinforced with man-made, synthetic fibers. These fibers are derived from organic polymers. Types of synthetic fibers that have been used to reinforce cement matrix are acrylic, aramid, carbon, nylon, polyester, polyethylene and polypropylene.

Properties of the most common synthetic fibers are shown in Table 2.3. 
Table 2.3 Properties of synthetic fibers (from ACI 544.1R)

\begin{tabular}{|c|c|c|c|c|c|c|c|c|}
\hline Fiber type & $\begin{array}{l}\text { Equivalent } \\
\text { diameter, } \\
\text { in. } \times 10^{-3}\end{array}$ & $\begin{array}{l}\text { Specific } \\
\text { gravity }\end{array}$ & $\begin{array}{c}\text { Tensile } \\
\text { strength, ksi }\end{array}$ & $\begin{array}{c}\text { Elastic } \\
\text { modulus, ksi }\end{array}$ & $\begin{array}{c}\text { Ultimate } \\
\text { elongation, } \\
\text { percent }\end{array}$ & $\begin{array}{c}\text { Ignition } \\
\text { temperature, }{ }^{\circ} \mathrm{F}\end{array}$ & $\begin{array}{l}\text { Melt, oxidation, or } \\
\text { decomposition } \\
\text { temperature, " } \mathrm{F}\end{array}$ & $\begin{array}{l}\text { Water absorption } \\
\text { per ASTM D } 570 \text {, } \\
\text { percent by weight }\end{array}$ \\
\hline Acrylic & $0.5-4.1$ & $1.16-1.18$ & $39-145$ & $2000-2800$ & $7.5-50.0$ & - & $430-455$ & $1.0-2.5$ \\
\hline Aramid I & 0.47 & 1.44 & 425 & 9000 & 4.4 & high & 900 & 4.3 \\
\hline Aramid $\mathrm{II}^{\uparrow}$ & 0.40 & 1.44 & 340 & 17,000 & 2.5 & high & 900 & 1.2 \\
\hline Carbon, PAN HM & 0.30 & $1.6-1.7$ & $360-440$ & 55,100 & $0.5-0.7$ & high & 752 & nil \\
\hline Carbon, PAN HT & 0.35 & $1.6-1.7$ & $500-580$ & 33,400 & $1.0-1.5$ & high & 752 & nil \\
\hline Carbon, pitch GP** & $0.39-0.51$ & $1.6-1.7$ & $70-115$ & $4000-5000$ & $2.0-2.4$ & high & 752 & $3-7$ \\
\hline Carbon, pitch $\mathrm{HP}^{\text {fi }}$ & $0.35-0.70$ & $1.80-2.15$ & $220-450$ & $22,000-70,000$ & $0.5-1.1$ & high & 932 & nil \\
\hline Nylon ${ }^{4+2}$ & 0.90 & 1.14 & 140 & 750 & 20 & - & $392-430$ & $2.8-5.0$ \\
\hline Polyester & 0.78 & $1.34-1.39$ & $33-160$ & 2500 & $12-150$ & 1100 & 495 & 0.4 \\
\hline Polyethylene & $1.0-40.0$ & $0.92-0.96$ & $11-85$ & 725 & $3-80$ & - & 273 & nil \\
\hline Polypropylene ${ }^{f t}$ & - & $0.90-0.91$ & $20-100$ & $500-700$ & 15 & 1100 & 330 & nil \\
\hline
\end{tabular}

Not all fiber types are currently used for commercial production of FRC.

'High modulus.

IPolyacrylonitrile based, high modulus.

SPolyacrylonitrile based, high tensile strength.

${ }^{* 4}$ Isotropic pitch based, general purpose.

"Mesophase pitch based, high performance.

"itData listed is only for fibers commercially available for FRC

Metric equivalents: 1 in. $=25.4 \mathrm{~mm} ; 1 \mathrm{ksi}=6.895 \mathrm{MPa}$; (degrees F -32$) / 1.8=$ degrees $\mathrm{C}$.

\subsubsection{Natural Fiber Reinforced Concrete (NFRC)}

NFRC is concrete reinforced with naturally occurring fibers. Some examples of natural fibers used in FRC are sisal, jute, coir, elephant grass, and sugar cane bagasse.

There are two broad categories of natural fibers. They are unprocessed natural fibers (UNF) and processed natural fibers (PNF). Generally unprocessed natural fibers have low modulus of elasticity and are typically used in low cost concrete in developing areas of the world. Processed natural fibers are obtained by chemically treating the available natural fibers. One such example is cellulose (wood pulp) fibers. These fibers have higher elastic modulus and tensile strength and have been extensively used for replacement of asbestos fibers.

Some typical properties of natural fibers are presented in Table 2.4. 
Table 2.4 Properties of natural fibers (from ACI 544.1R)

\begin{tabular}{c|c|c|c|c|c|c|c|c|c|c|c}
\hline Fiber type & Coconut & Sisal & $\begin{array}{c}\text { Sugar cane } \\
\text { Bagasse }\end{array}$ & Bamboo & Jute & Flax & $\begin{array}{c}\text { Elephant } \\
\text { grass }\end{array}$ & $\begin{array}{c}\text { Water } \\
\text { reed }\end{array}$ & Plantain & Musamba & $\begin{array}{c}\text { Wood fiber } \\
\text { (kraft pulp) }\end{array}$ \\
\hline Fiber length, in. & $2-4$ & N/A & N/A & N/A & $7-12$ & 20 & N/A & N/A & N/A & N/A & $0.1-0.2$ \\
\hline $\begin{array}{c}\text { Fiber } \\
\text { diameter, in. }\end{array}$ & $\begin{array}{c}0.004- \\
0.016\end{array}$ & N/A & $\begin{array}{c}0.008- \\
0.016\end{array}$ & $\begin{array}{c}0.002- \\
0.016\end{array}$ & $\begin{array}{c}0.004- \\
0.008\end{array}$ & N/A & N/A & N/A & N/A & N/A & $0.001-0.003$ \\
\hline Specific gravity & $1.12-1.15$ & N/A & $1.2-1.3$ & 1.5 & $1.02-1.04$ & N/A & N/A & N/A & N/A & N/A & 1.5 \\
\hline $\begin{array}{c}\text { Modulus of elasticity, } \\
\text { ksi }\end{array}$ & $\begin{array}{c}2750- \\
3770\end{array}$ & $\begin{array}{c}1880- \\
3770\end{array}$ & $2175-2750$ & $\begin{array}{c}4780- \\
5800\end{array}$ & $3770-4640$ & 14,500 & 710 & 750 & 200 & 130 & N/A \\
\hline $\begin{array}{c}\text { Ultimate } \\
\text { tensile strength, psi }\end{array}$ & $\begin{array}{c}17,400- \\
29,000\end{array}$ & $\begin{array}{l}40,000- \\
82,400\end{array}$ & $\begin{array}{c}26,650- \\
42,000\end{array}$ & $\begin{array}{c}50,750- \\
72,500\end{array}$ & $\begin{array}{c}36,250- \\
50,750\end{array}$ & 145,000 & 25,800 & 10,000 & 13,300 & 12,000 & 101,500 \\
\hline $\begin{array}{c}\text { Elongation at break, } \\
\text { percent }\end{array}$ & $10-25$ & $3-5$ & N/A & N/A & $1.5-1.9$ & $1.8-2.2$ & 3.6 & 1.2 & 5.9 & 9.7 & N/A \\
\hline $\begin{array}{c}\text { Water } \\
\text { absorption, percent }\end{array}$ & $130-180$ & $60-70$ & $70-75$ & $40-45$ & N/A & N/A & N/A & N/A & N/A & N/A & $50-75$ \\
\hline
\end{tabular}

Note: N/A = properties not readily available or not applicable.

Metric equivalents: 1 in. $=25.4 \mathrm{~mm} ; 1 \mathrm{ksi}=1000 \mathrm{psi}=6.895 \mathrm{MPa}$

\subsection{Detailed Literature Review on HPFRC}

\subsubsection{Properties of freshly-mixed HPFRC}

Ramakrishnan (1987) showed that the fiber properties, such as, aspect ratio, geometry, volume fraction, and bond characteristics affect the properties of SFRC in its freshly mixed state. Since the strength and other properties of SFRC in its hardened state are greatly influenced by the degree of consolidation, adequate workability should be ensured during placing of SFRC. Compaction by mechanical vibration is recommended in most SFRC applications as the addition of steel fibers may reduce the measured slump of the composite compared to a non-fibrous mixture in the range of 1 to 4 in. (25 to $102 \mathrm{~mm}$ ). Studies by Atis and Karahan (2009) showed that inclusion of steel fiber reduces workability of FRC. Balaguru and Ramakrishnan (1987) studied the effect of workability on the consolidation properties of FRC and found that a mixture with a relatively low slump can have good consolidation properties under vibration. ACI 544.1R recommends the use of Inverted Slump-Cone Time or Vebe consistometer while assessing the workability of an SFRC mixture. Figure 2.6 shows a typical relationship between slump, Vebe time, and Inverted Slump-Cone time (Johnston 1984). 


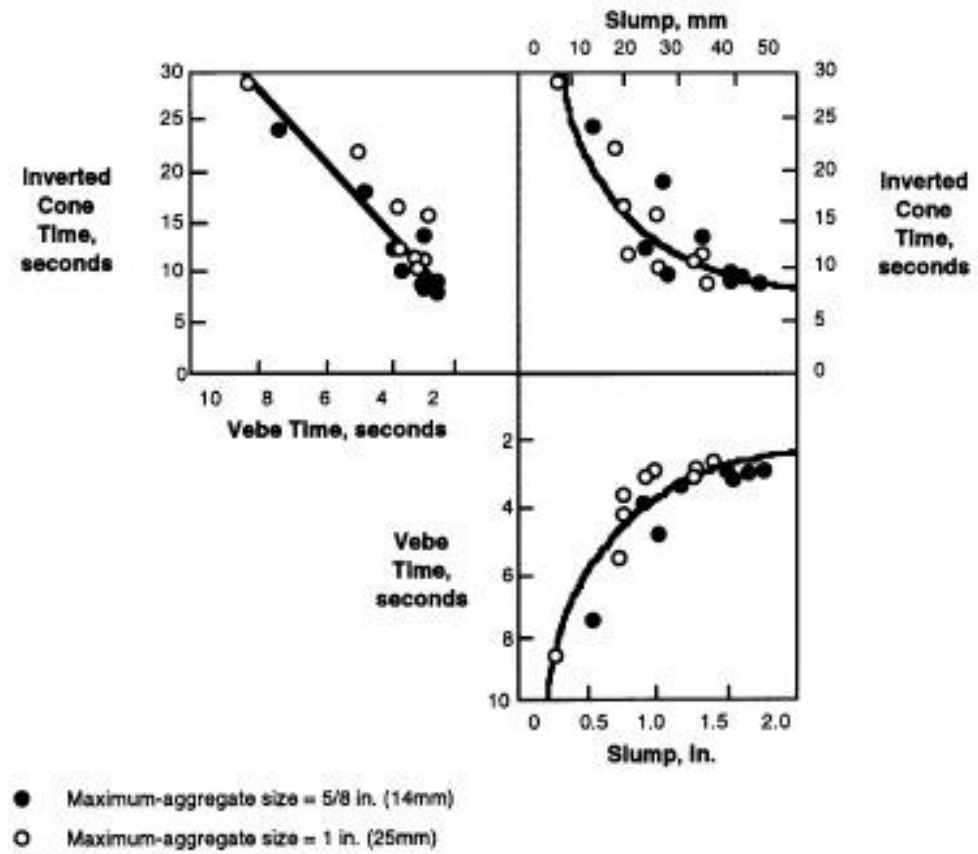

Fber Length $=3 / 4$ to $11 / 2$ in. $(19-38 \mathrm{~mm})$

Figure 2.6 Relationship between slump, Vebe time \& Inverted Slump-cone time (from Johnston 1984)

Balaguru and Ramakrishnan (1988) found that slump loss characteristics with time for SFRC and non-fibrous concrete are similar. Studies by Hannant (1978) found that long thin steel fibers having aspect ratio greater than 100 will have more tendencies to interlock to form a mat, or ball than short fibers with an aspect ratio less than 50. Mohammadi et al. (2008) also showed that lower aspect ratio of fibers results in higher compaction factor or lower inverted slump cone time and Vebe time. At the same time it is true that a high aspect ratio of steel fibers is preferred for improvement of some mechanical properties in the hardened state of HPFRC.

Studies by Mohammadi et al. (2008) also showed that workability of concrete decreases uniformly with the increase in fiber content. Hence, optimum fiber content is necessary for development of a workable mix.

\subsubsection{Properties of HPFRC at Hardened State}

\subsubsection{Compressive Strength}

Researchers have shown that the addition of fibers only nominally increases the ultimate compressive strength of FRC (Atis and Karahan 2009, Johnston 1974, Dixon and Mayfield 1971, and Kar and Pal 1972). Fiber volume fraction of up to $1.5 \%$ has shown to 
increase the compressive strength from 0 to $15 \%$ (Chen and Carson 1971 and Williamson 1974).

Very high compressive strength of HPFRC is achieved by increasing the packing density of the matrix. Packing density is increased by decreasing the porosity of the cementitious materials (Wille et al. 2011). Yudenfreund et al. (1972) obtained a compressive strength of $230 \mathrm{MPa}$ (33 ksi) by lowering the porosity of cement paste specimens. Bache achieved compressive strength in the range of 120 to $250 \mathrm{MPa}$ (17 to 36 ksi) by decreasing the porosity with the addition of microsilica and high-range water reducer. Recently, Wille et al. (2011) developed ultra high performance concrete having compressive strength greater than $200 \mathrm{MPa}$ (30 ksi) using materials commercially available in the US market and without the use of any heat treatment, pressure, or special mixer.

\subsubsection{Flexural Strength}

Steel fibers substantially increase the flexural strength of concrete. The ductile behavior of the SFRC on the tension side of a beam alters the normally elastic distribution of stress and strain over the member depth (ACI 544.1R). The altered stress distribution is essentially plastic in the tension zone and elastic in the compression zone, resulting in a shift of the neutral axis toward the compression zone (Hannant 1978). Romualdi and Mandel (1964) found that higher fiber volume fraction (4 percent) can double the flexural strength of concrete. Studies by Shah and Rangan (1971) and Works and Untrauer (1964) have shown that the flexural strength of SFRC is about 50 to 70 percent greater than that of conventional concrete in the third-point loading test. Snyder and Lankard (1972) have shown that specimens with small size or higher fiber volume fractions have greater flexural strength.

Type of fiber also influences the flexural strength of concrete. Kim et al. (2008) showed that concrete specimens reinforced with high strength steel twisted fibers have greater load carrying capacity than specimens with high strength steel hooked fibers and high molecular weight polyethylene spectra and PVA-fibers.

\subsubsection{Toughness}

Toughness is one characteristic of SFRC that most clearly differentiates it from conventional unreinforced concrete (Shah and Winter 1966). Under flexure, it can be demonstrated by the load-displacement behavior of simple beams (Johnston 1986). Toughness of SFRC is generally determined by flexural loading. Figure 2.7 and Figure 2.8 
show the toughness calculation by JSCE SF-4 and ASTM C1609, respectively. Details of these methods along with a discussion of their merits and drawbacks are presented in (Johnston 1986 and Nanni 1991).

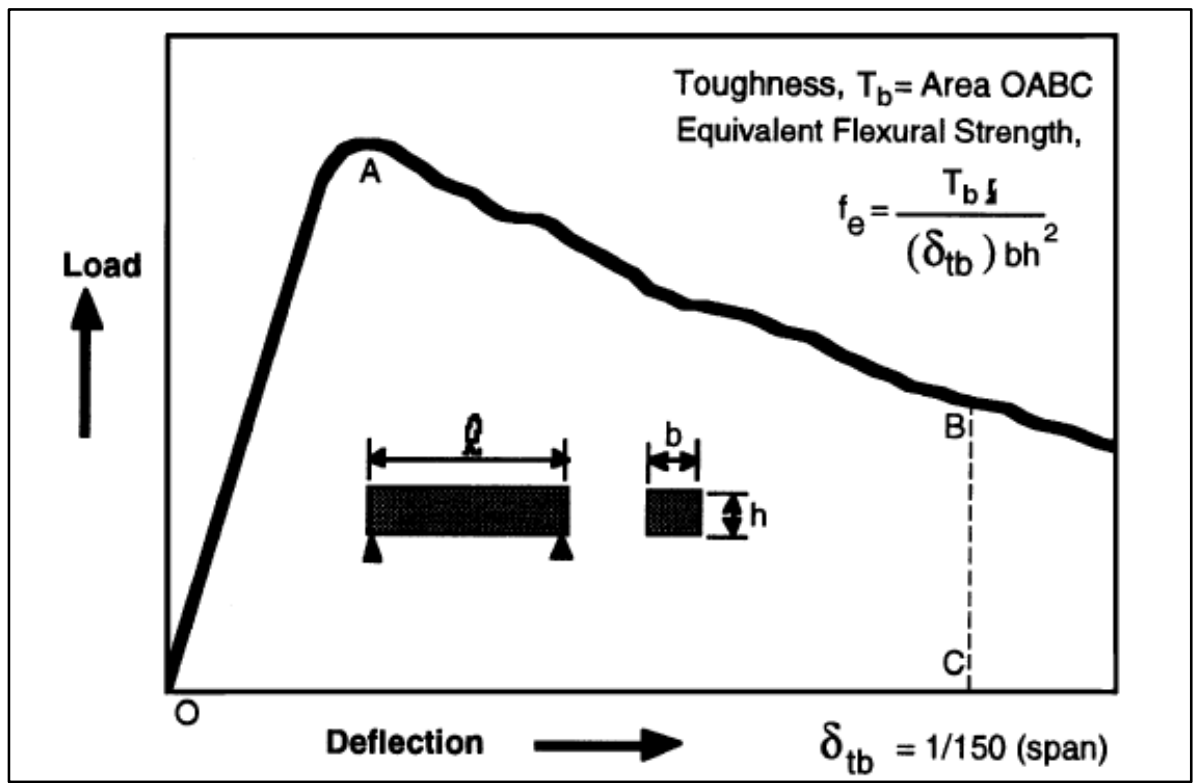

Figure 2.7 Toughness calculation by JSCE SF-4 method

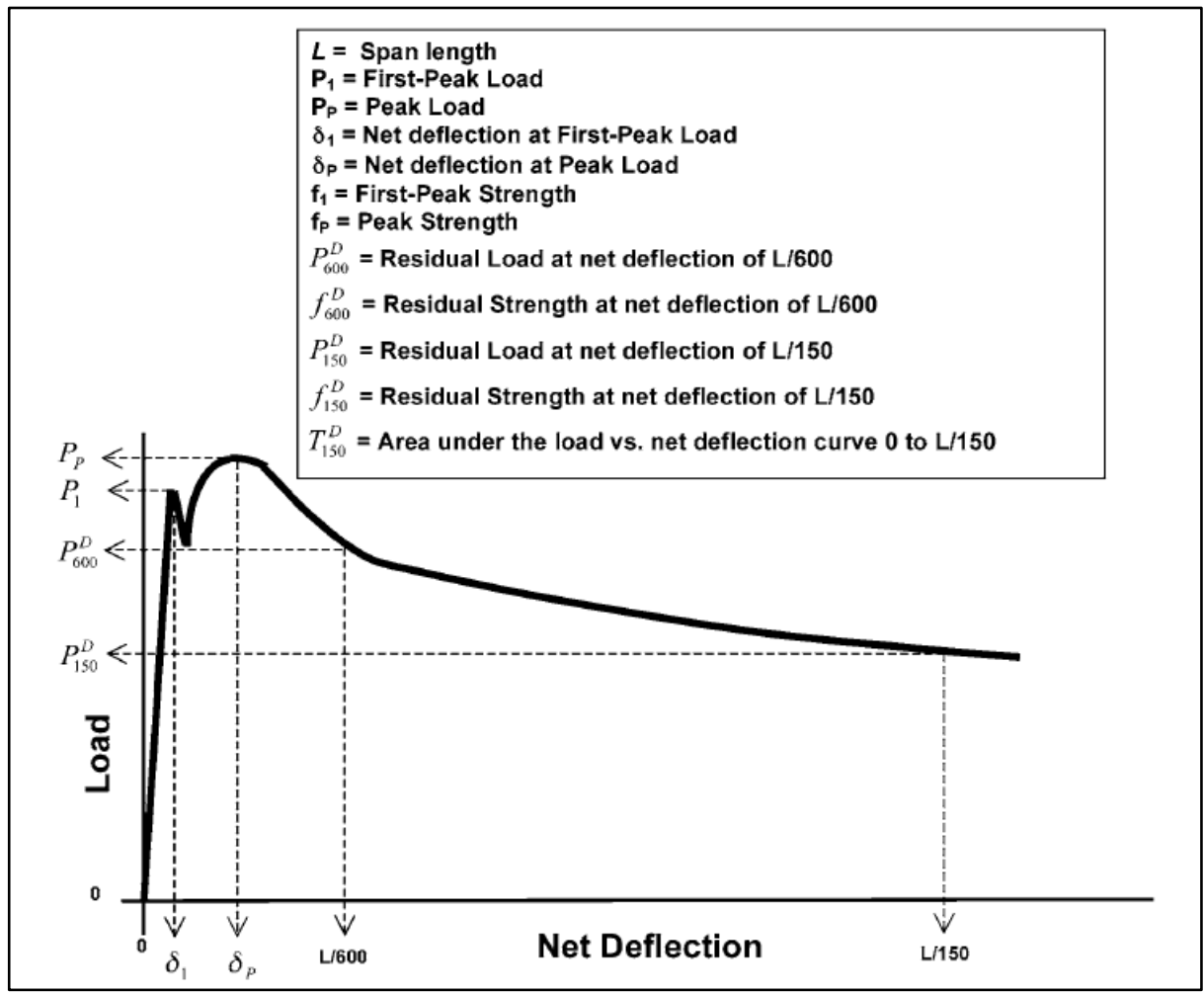

Figure 2.8 Toughness calculation by ASTM 1609 method 
ASTM C1609 recommends determination of toughness at span/600 and span/150 points. However, Kim et al. (2008) found that these two points are insufficient to fully differentiate between effects of different fibers on HPFRCC. Hence, they added one additional point, namely, span/100 for calculation of toughness. Kim (2009) also found that the toughness of HPFRCC with high strength matrix is greater than that with low strength matrix.

\subsection{Literature Review on Interface Bond Strength}

Dhir (1984) studied the adverse effects of large temperature variations that occur when overlaying is done in intemperate weather. He used a direct shear test method to determine the shear bond strength. He showed that panel peripheries developed inadequate bond result when concreting was done under large temperature variations.

Sprinkel (1988) used a shear apparatus in the shape of a guillotine to determine the shear bond strength of different overlays. He obtained average bond strength of $4 \mathrm{MPa}$ (580 psi) at 28 days.

O'Connor and Saiidi (1993) studied the bond strength between overlay concrete and portland cement concrete by using the California Test 551. Results showed that polymer concrete overlays might be prone to cracking when subjected to large temperature variations.

Ali et al. (1998) showed that shear bond strength was significantly improved by introduction of bonding agent. Surface roughness played an important role in developing bond strength when there was no bonding agent.

Luo (2002) developed a block shear test apparatus to evaluate the overlay-substrate interface behavior of butterfly-shaped bi-layer specimens with two different substrate surface preparation conditions, namely, mechanical abrasion and chemical etching. Results indicated that mechanical abrasion performed marginally better than chemical etching for most of the bi-layer specimens.

Sun (2004) later modified the shear test apparatus originally developed by Luo (2002) due to high strength capacity of his specimens. He showed that overlay mixture type and substrate surface preparation could affect bond strength significantly. 
Sarkar (2010) performed slant shear test to evaluate the bond strength between UHPC and type III portland cement mortar. Her study demonstrated that in slant shear test with properly rough substrate surface, the bond strength is greater than the strength of substrate. However, in case of no surface preparation, failure consistently occurred at the interface. 


\section{CHAPTER 3 MATERIALS AND MIXTURE PROPORTIONS}

This chapter describes the materials and the mixture proportions those were used to develop HPFRC and NC. Mixing procedures, casting procedures, and different curing conditions for both HPFRC and NC are also described in this chapter.

\subsection{Materials}

\subsubsection{Cement}

Cement is the principal binder component of concrete. In this study, two different types of cement were used to produce HPFRC and NC. They are described in 3.1.1.1 and 3.1.1.2, respectively.

\subsubsection{Cement for HPFRC}

Commercially available Type I portland cement conforming to ASTM C150 (Standard Specification for Portland Cement) with a relatively low tricalcium aluminate $\left(C_{3} A\right)$ content was used to develop HPFRC. The reason for selecting cement with low $C_{3} A$ content is that the hydration reactions of the aluminates are much faster than that of the silicates and the associated increase in the surface area of the particles demands more water causing considerable loss of consistency at an early stage (Taylor 1997). Low $\mathrm{C}_{3} \mathrm{~A}$ content reduces the water demand during hydration and hence, more water is available for mixing.

This cement was supplied by Armstrong Cement \& Supply from its mill in Cabot, Pa. The basic physical properties and the compound compositions of this type of cement are presented in Table 3.1 and Table 3.2, respectively.

Table 3.1 Physical properties of portland cement used for HPFRC

\begin{tabular}{ccc}
\hline Properties & Units & Values \\
\hline Specific Gravity & - & 3.15 \\
Fineness (Blaine) & $\mathrm{m}^{2} / \mathrm{kg}$ & 367.5 \\
Initial Time of Setting (Vicat) & $\min$. & 120 \\
Final Time of Setting (Vicat) & $\min$. & 255 \\
\hline \multicolumn{2}{c}{ Note: $1 \mathrm{~m}^{2} / \mathrm{kg}=703.081 \mathrm{in}^{2} / \mathrm{lb}$} &
\end{tabular}


Table 3.2 Compound compositions of portland cement used for HPFRC

\begin{tabular}{cc}
\hline Compounds & \% by mass \\
Silica $\left(\mathrm{SiO}_{2}\right)$ & 20.20 \\
Lime $(\mathrm{CaO})$ & 63.60 \\
Iron Oxide $\left(\mathrm{Fe}_{2} \mathrm{O}_{3}\right)$ & 5.40 \\
Magnesia $(\mathrm{MgO})$ & 4.30 \\
Sulfur Trioxide $\left(\mathrm{SO}_{3}\right)$ & 0.94 \\
Loss on Ignition $\left(\mathrm{LOI}_{2} \mathrm{O}_{3}\right)$ & 3.00 \\
Insoluble Residue & 1.35 \\
Alkalies $\left(\mathrm{Na}_{2} \mathrm{O}+0.658 \mathrm{~K}_{2} \mathrm{O}\right)$ & 0.30 \\
Tricalcium Aluminate $\left(\mathrm{C}_{3} \mathrm{~A}\right)$ & 0.56 \\
\hline & 7.20 \\
\hline
\end{tabular}

\subsubsection{Cement for NC}

Commercially available Type I portland cement conforming to ASTM C150 (Standard Specification for Portland Cement) and supplied by Arrow Concrete (WV) was used to develop NC.

The basic physical properties and the compound compositions of this type of cement are presented in Table 3.3 and Table 3.4 respectively. 
Table 3.3 Physical properties of portland cement used for NC

\begin{tabular}{ccc}
\hline Properties & Unit & Values \\
\hline Specific Gravity & - & 3.15 \\
Fineness (Blaine) & $\mathrm{m}^{2} / \mathrm{kg}$ & 320 \\
Initial Time of Setting (Vicat) & min. & 90 \\
Final Time of Setting (Vicat) & min. & 260 \\
\hline \multicolumn{2}{c}{ Note: $1 \mathrm{~m}^{2} / \mathrm{kg}=703.081 \mathrm{in}^{2} / \mathrm{lb}$}
\end{tabular}

Table 3.4 Compound compositions of portland cement used for NC

\begin{tabular}{cc}
\hline Compounds & \% by mass \\
\hline Tricalcium Silicate $\left(\mathrm{C}_{3} \mathrm{~S}\right)$ & 49.00 \\
Dicalcium Silicate $\left(\mathrm{C}_{2} \mathrm{~S}\right)$ & 25.00 \\
Tricalcium Aluminate $\left(\mathrm{C}_{3} \mathrm{~A}\right)$ & 12.00 \\
Tetracalcium Aluminoferrite & \\
( $\left.\mathrm{C}_{4} \mathrm{AF}\right)$ & 8.00 \\
Gypsum $\left(\mathrm{C} \mathrm{H}_{2}\right)$ & 2.80 \\
Free Lime $(\mathrm{CaO})$ & 0.80 \\
Free Magnesia $(\mathrm{MgO})$ & 1.40 \\
Others & 2.00 \\
\hline
\end{tabular}

\subsubsection{Coarse Aggregates}

\subsubsection{Coarse Aggregates for HPFRC}

In order to achieve a highly homogeneous concrete matrix, no coarse aggregate was used to develop HPFRC. 


\subsubsection{Coarse Aggregates for NC}

Crushed limestone conforming to ASTM C33 (Standard Specification for Concrete Aggregates) having $12.5 \mathrm{~mm}$ nominal size was used for producing NC. This was supplied by Arrow Concrete (WV). The basic physical properties and the sieve analysis data for this type of aggregates are presented in Table 3.5 and Table 3.6 respectively.

Table 3.5 Physical properties of coarse aggregates used for NC

\begin{tabular}{ccc}
\hline Properties & Unit & Values \\
\hline Nominal Size & $\mathrm{mm}$ & 12.50 \\
Absorption (\%) & $\%$ & 0.53 \\
SSD Specific Gravity & - & 2.69 \\
Bulk Specific Gravity & - & 2.68 \\
Apparent Specific Gravity & - & 2.72 \\
\hline
\end{tabular}

Note: $1 \mathrm{~mm}=0.039$ inch

Table 3.6 Sieve analysis data for coarse aggregates used for NC

\begin{tabular}{cc}
\hline Sieve size $(\mathbf{m m})$ & \% passing (by wt.) \\
\hline 12.5 & 100.00 \\
9.5 & 88.10 \\
4.75 & 13.67 \\
2.36 & 1.30 \\
1.18 & 1.02 \\
\hline
\end{tabular}

Note: $1 \mathrm{~mm}=0.039$ inch

\subsubsection{Fine Aggregates}

Different types of sand were used to produce HPFRC and NC. They are described below: 


\subsubsection{Fine Aggregates for HPFRC}

\subsection{Fine Sand}

Two different types of fine natural sand, commercially known as Sand OO and Sand OOO, were used to develop HPFRC. They were supplied by Ricci Brothers Sand Co. Inc. based in New Jersey.

The physical properties, sieve analysis data, and major chemical compositions of Sand $\mathrm{OO}$ and Sand $\mathrm{OOO}$ are presented in Table 3.7, Table 3.8, and Table 3.9, respectively.

Table 3.7 Physical properties of fine natural sand used for HPFRC

\begin{tabular}{cc}
\hline Properties & Values \\
\hline Specific Gravity & 2.65 \\
Hardness (Moh's scale) & $6-8$ \\
\hline
\end{tabular}

Table 3.8 Sieve analysis data for fine natural sand used for HPFRC \% passing (by wt.)

\section{Sieve size $(\mathrm{mm})$}

Sand $00 \quad$ Sand 000

$\begin{array}{lcc}0.85 & 100 & 100 \\ 0.60 & 95 & 100 \\ 0.42 & 40 & 95 \\ 0.30 & 5 & 75 \\ 0.25 & 2 & 45 \\ 0.21 & 1 & 30 \\ 0.15 & & 5\end{array}$

Note: $1 \mathrm{~mm}=0.039$ inch 
Table 3.9 Major compound compositions of fine natural sand used for HPFRC

Compounds $\quad \%$ by mass

\begin{tabular}{lc}
$\mathrm{SiO}_{2}$ & $98-99$ \\
$\mathrm{Al}_{2} \mathrm{O}_{3}$ & $0.03-0.3$ \\
$\mathrm{Fe}_{2} \mathrm{O}_{3}$ & $0.03-0.3$ \\
\hline
\end{tabular}

\subsection{Ultrafine Quartz Powder}

Sil-co-sil 90 (SCS), containing crystalline silica (mineral quartz) and supplied by US Silica Company (WV), was used as the third constituent in the fine aggregates category. The physical properties, sieve analysis data, and the major chemical compositions of SCS are presented in Table 3.10, Table 3.11, and Table 3.12, respectively.

Table 3.10 Physical properties of ultrafine quartz powder used for HPFRC

\begin{tabular}{cc}
\hline Properties & Values \\
\hline Specific Gravity & 2.65 \\
Hardness (Moh's scale) & 7 \\
\hline
\end{tabular}

Table 3.11 Sieve analysis data for ultrafine quartz powder used for HPFRC

$\begin{array}{cc}\text { Sieve size }(\mathbf{m m}) & \text { \% passing (by wt.) } \\ 0.15 & 100.0 \\ 0.106 & 99.8 \\ 0.075 & 97.3 \\ 0.053 & 88.8 \\ 0.045 & 82.3\end{array}$


Note: $1 \mathrm{~mm}=0.039$ inch

Table 3.12 Compound compositions of ultrafine quartz powder used for HPFRC

\begin{tabular}{cc}
\hline Compounds & \% by mass \\
\hline $\mathrm{SiO}_{2}$ & 99.7 \\
$\mathrm{Al}_{2} \mathrm{O}_{3}$ & 0.12 \\
$\mathrm{Fe}_{2} \mathrm{O}_{3}$ & 0.021 \\
$\mathrm{TiO}_{2}$ & 0.009 \\
$\mathrm{CaO}$ & 0.009 \\
$\mathrm{MgO}, \mathrm{K}_{2} \mathrm{O}$ & $<0.01$ (each) \\
Loss On Ignition & 0.1 \\
\hline
\end{tabular}

\subsubsection{Fine Aggregates for NC}

Locally available river sand conforming to ASTM C33 (Standard Specification for Concrete Aggregates) was used to produce NC. This sand was supplied by Arrow Concrete (WV). The physical properties and sieve analysis data are presented in Table 3.13 and Table 3.14 , respectively.

Table 3.13 Physical properties of river sand used for NC

\begin{tabular}{cc}
\hline Properties & Values \\
\hline Fineness modulus & 2.79 \\
Absorption (\%) & 1.0 \\
SSD Specific Gravity & 2.61 \\
Bulk Specific Gravity & 2.59 \\
Apparent Specific Gravity & 2.65 \\
\hline
\end{tabular}


Table 3.14 Sieve analysis data for river sand used for NC

\begin{tabular}{cc}
\hline Sieve size $(\mathbf{m m})$ & \% passing (by wt.) \\
\hline 19 & 100.0 \\
4.75 & 97.2 \\
2.36 & 82.3 \\
1.18 & 69.0 \\
0.600 & 54.6 \\
0.300 & 16.1 \\
0.150 & 2.0 \\
0.075 & 0.7 \\
\hline
\end{tabular}

Note: $1 \mathrm{~mm}=0.039$ inch

\subsubsection{Mineral Admixtures}

\subsubsection{Mineral Admixtures for HPFRC}

\subsection{Silica Fume}

Silica fume is a by-product of the silicon metal and the ferrosilicon alloy industries. The particles of silica fume $(<1 \mu \mathrm{m})$ are finer than the ordinary portland cement and hence, improve the packing density of the cement matrix. It is a highly pozzolanic material with a high surface area which increases the water requirement in concrete unless adequate amount of high range water-reducing admixture is used. In the present study, a densified silica fume mineral admixture (commercial name - Rheomac SF 100) manufactured by BASF Construction Chemicals was used. It meets the requirements of ASTM C1240 (Standard Specification for Silica Fume Used in Cementitious Mixtures).

The basic properties and major chemical compositions of this silica fume are shown in Table 3.15. 
Table 3.15 Basic properties and major chemical compositions of silica fume

\begin{tabular}{cc}
\hline Properties & Values \\
\hline Specific Gravity & 2.2 \\
$\mathrm{SiO}_{2}(\%)$ & $60-100$ \\
Crystalline $\mathrm{SiO}_{2}(\%)$ & $0.5-1.5$ \\
\hline
\end{tabular}

\subsubsection{Mineral Admixtures for NC}

No mineral admixture was used to produce NC.

\subsubsection{Chemical Admixtures}

Chemical admixtures are an integral part of modern day concrete. Different types of chemical admixtures are added to concrete for different purposes. For example, airentraining agents are added primarily to improve the resistance of concrete to freezing and thawing; set-controlling admixtures are added to control the setting time of concrete; plasticizing admixtures are added to concrete to enhance workability by increasing slump or to reduce the water requirement for the desired workability. The chemical admixtures that were used in the present study are described below:

\subsubsection{Chemical Admixtures for HPFRC}

\subsection{High Range Water Reducing Admixture (HRWRA)}

A commercially available polycarboxylate based full-range water reducing admixture (commercial name - Glenium 7500) manufactured by BASF Construction Chemicals was used in developing HPFRC. It has a density of $1.05 \mathrm{~g} / \mathrm{cm}^{3}\left(65.52 \mathrm{lb} / \mathrm{ft}^{3}\right)$ at $20^{\circ} \mathrm{C}\left(68^{\circ} \mathrm{F}\right)$ and conforms to ASTM C494 (Standard Specification for Chemical Admixtures for Concrete) compliance requirements for type $A$ (water reducing) and type $F$ (high-range water reducing) admixtures.

In order to produce a workable concrete mixture with water to cementitious materials ratio $(\mathrm{w} / \mathrm{cm})$ as low as 0.2 and with $25 \%$ replacement of cementitious materials by silica fume, HRWRA was used at a much higher rate than that is recommended by the manufacturer for NC. 


\subsection{Workability Retaining Admixture}

Commercially available workability retaining admixture (commercial name RheoTEC Z-60) manufactured by BASF Construction Chemicals was used to retain workability of HPFRC without retardation. It has a relative density of 1.043 at $20^{\circ} \mathrm{C}\left(68^{\circ} \mathrm{F}\right)$ and conforms to type S (specific performance) admixtures as per ASTM C494 (Standard Specification for Chemical Admixtures for Concrete).

\subsubsection{Chemical Admixtures for NC}

\subsection{Air-Entraining Admixture}

MB-AE 90 (manufactured by BASF Construction Chemicals) was used as the airentraining admixture (AEA) to produce NC. It has a relative density of 1.012 at $20^{\circ} \mathrm{C}\left(68^{\circ} \mathrm{F}\right)$ and conforms to ASTM C260 (Standard Specification for Air-Entraining Admixtures for Concrete).

\subsubsection{Fiber}

Commercially available, straight drawn, high carbon, brass coated, discontinuous steel fibers (OL 13/.20) manufactured by Bekaert (Figure 3.1) were used to increase the post-cracking ductility of HPFRC. These fibers conform to ASTM A820 (Standard Specification for Steel Fibers for Fiber-Reinforced Concrete). The geometric and material properties of the fibers are shown in Table 3.16.

Table 3.16 Geometric and material properties of steel fibers

\begin{tabular}{ccc}
\hline Properties & Unit & Values \\
\hline Length & $\mathrm{mm}$ & 13 \\
Diameter & $\mathrm{mm}$ & 0.20 \\
Aspect ratio & - & 65 \\
Tensile strength & MPa & 2160 \\
Young's modulus & $\mathrm{GPa}$ & 210 \\
Specific Gravity & - & 7.85 \\
\hline
\end{tabular}


Note: $1 \mathrm{~mm}=0.039$ inch; $1 \mathrm{MPa}=145 \mathrm{psi} ; 1 \mathrm{GPa}=145 \mathrm{ksi}$

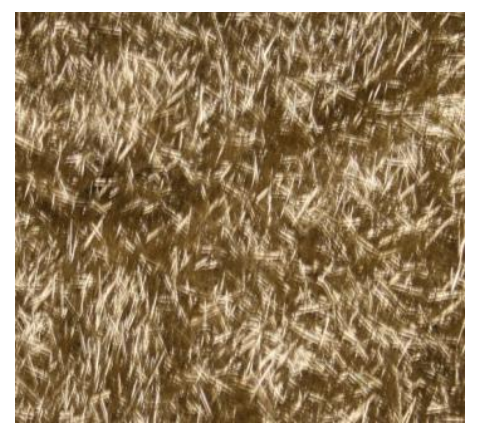

Figure 3.1 Steel fibers used for HPFRC

\subsubsection{Mixing Water}

\subsubsection{Mixing Water for HPFRC}

Compared to conventional concrete, HPFRC requires more energy while mixing the ingredients. Since a normal kitchen mixer was used to mix the ingredients of HPFRC, the mixing time was more than that of the conventional concrete. In order to prevent HPFRC from overheating during mixing, cold and potable water $\left(\sim 10^{\circ} \mathrm{C}\right.$ or $\left.\sim 50^{\circ} \mathrm{F}\right)$ was used. It was assumed to have a density of $1000 \mathrm{~kg} / \mathrm{m}^{3}\left(62.4 \mathrm{lb} / \mathrm{ft}^{3}\right)$.

\subsubsection{Mixing Water for NC}

Tap water supplied by the Morgantown Utility Board was used in producing NC. This water was assumed to have a density of $1000 \mathrm{~kg} / \mathrm{m}^{3}\left(62.4 \mathrm{lb} / \mathrm{ft}^{3}\right)$.

\subsection{Mixture Proportioning}

\subsubsection{Mixture Proportioning for HPFRC}

Particle size of the individual ingredients and their relative proportions are of paramount importance in developing a workable HPFRC mix which in turn imparts the desired properties in the hardened state. After extensive review of existing literatures, the following decisions were taken at the outset.

\subsubsection{Initial Selection Criteria}

a. In order to improve the packing density of the cement matrix, quantity of silica fume will be equal to $25 \%$ (by wt.) of total cementitious materials (cement + silica fume).

b. $w / c m$ needs to be kept below 0.25 . 
c. The volume fraction of the steel fibers will be $2 \%$ of the total volume of concrete.

d. Ultrafine quartz powder content will be 10 to $20 \%$ of total fine aggregates. (Optimization of the particle size distribution curve for fine aggregates is discussed in detail in the following paragraph.)

\subsubsection{Optimization of Particle Size Distribution Curve of Fine Aggregates}

The particle size distribution curve was optimized as follows:

a. In the first case, quantity of ultrafine quartz powder (SCS) was considered to be $10 \%$ (by wt.) of total fine aggregates and the quantities of Sand OO (denoted as OO) and Sand 000 (denoted as OOO) were varied from $10-80 \%$ and $80-10 \%$, respectively. The combined grading of the total fine aggregates corresponding to each of the above variation was plotted in an MS Excel spreadsheet along with the individual grading of OO, OOO, and SCS. The plot is reproduced in Figure 3.2. From the plot it is evident that the median curve $(00-45 \%+000-45 \%+$ SCS$10 \%$ ) has a gradient which is neither too steep nor too flat. In order to get a well graded fine aggregate proportion, this curve was selected as the optimized curve.

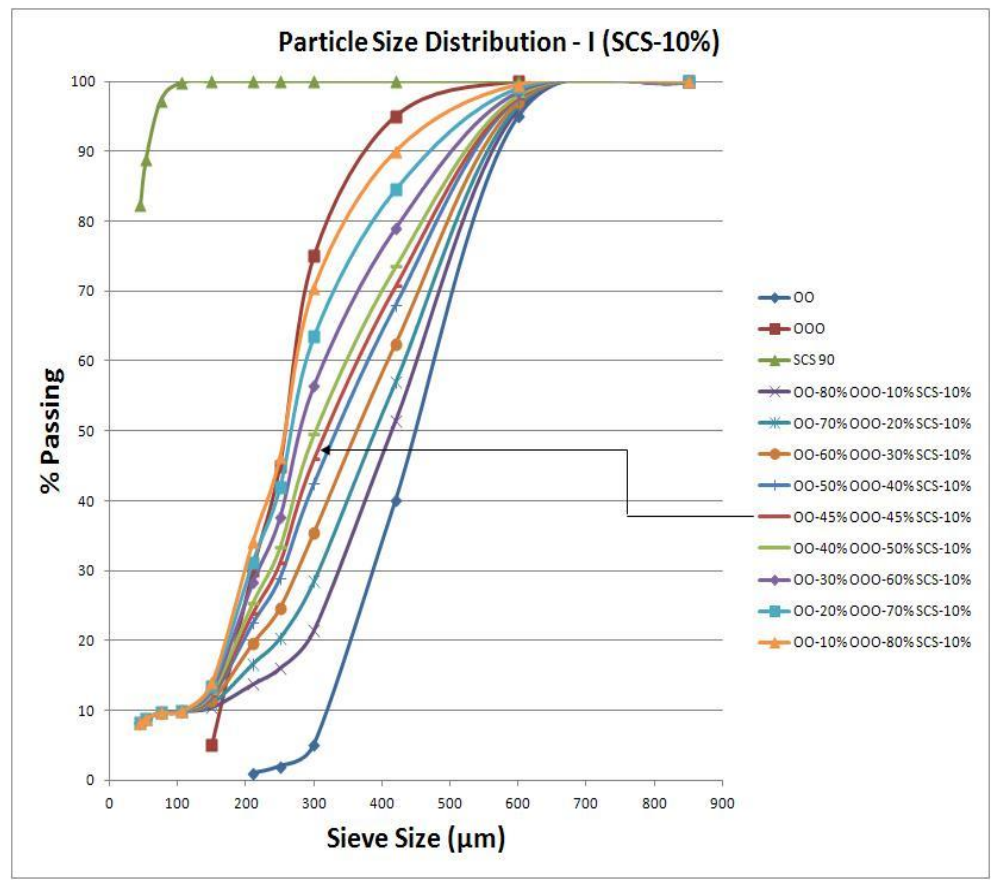

Note: $1 \mu \mathrm{m}=3.937 \times 10^{-5}$ inch

Figure 3.2 Particle size distribution curve - I (SCS-10\%) 
b. In the second case, quantity of SCS was considered to be $20 \%$ (by wt.) of total fine aggregates and the quantities of Sand OO (OO) and Sand OOO (OOO) were varied from $10-70 \%$ and $70-10 \%$ respectively. The combined grading of the total fine aggregates corresponding to each of the above variation was plotted in an MS Excel spreadsheet along with the individual grading of 00,000 , and SCS. The plot is reproduced in Figure 3.3. From the plot it is evident that the median curve $(00-40 \%+000-40 \%+$ SCS-20\%) has a gradient which is neither too steep nor too flat. In order to get a well graded fine aggregate proportion, this curve was selected as the optimized curve.

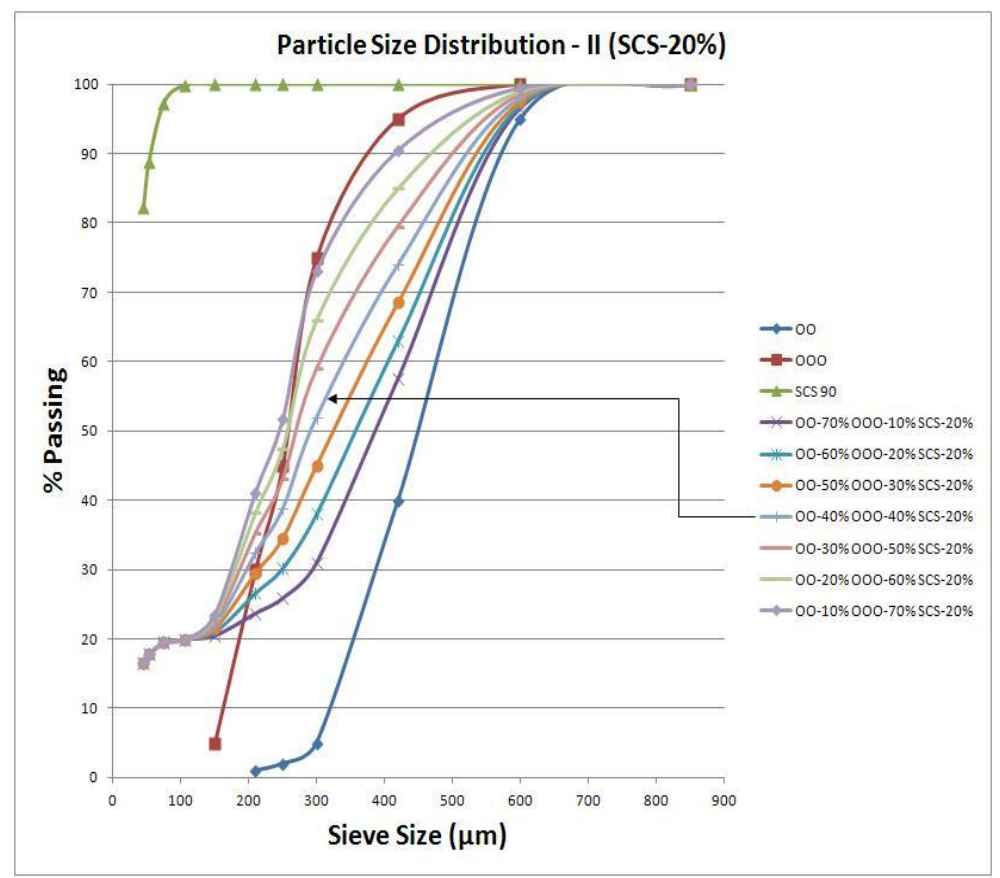

Note: $1 \mu \mathrm{m}=3.937 \times 10^{-5}$ inch

Figure 3.3 Particle size distribution curve - II (SCS-20\%)

c. In the third case, quantity of SCS was considered to be $15 \%$ (by wt.) of total fine aggregates and the quantities of Sand $\mathrm{OO}(\mathrm{OO})$ and Sand 000 (OOO) were varied from $15-75 \%$ and $70-10 \%$ respectively. The combined grading of the total fine aggregates corresponding to each of the above variation was plotted in an MS Excel spreadsheet along with the individual grading of 00,000 , and SCS. The plot is reproduced in Figure 3.4. From the plot it is evident that the median curve $(00-45 \%+000-40 \%+\mathrm{SCS}-15 \%)$ has a gradient which is neither too 
steep nor too flat. In order to get a well graded fine aggregate proportion, this curve was selected as the optimized curve.

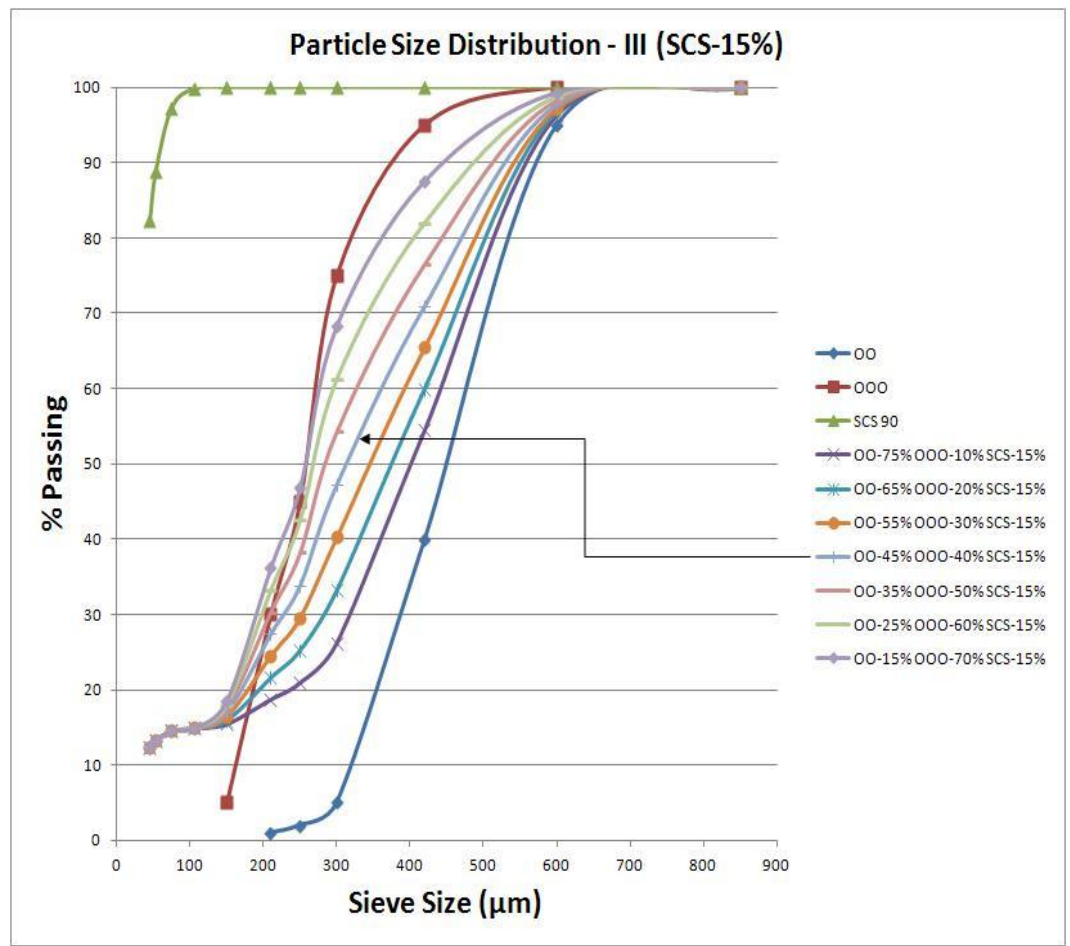

Note: $1 \mu \mathrm{m}=3.937 \times 10^{-5}$ inch

Figure 3.4 Particle size distribution curve - III (SCS-15\%)

d. The three optimized curves obtained from above are plotted again in an MS Excel spreadsheet. This plot is reproduced in Figure 3.5. From Figure 3.5, the two extreme curves $(00-45 \%+000-45 \%+$ SCS $-10 \%$ and $00-40 \%+000-40 \%+$ SCS-20\%) were finally selected so that there would be some variations in the results. These desired variations would help in understanding properly the effect of gradation of the fine aggregates on the hardened properties of HPFRC. Hence, the corresponding proportions of the fine aggregates were used to develop HPFRC. Based on the quantity of ultrafine quartz powder, henceforth, $00-45 \%+$ 00O-45\% + SCS-10\% will be denoted as coarser fraction and 00-40\% + 000$40 \%+$ SCS $-20 \%$ will be denoted as finer fraction. 


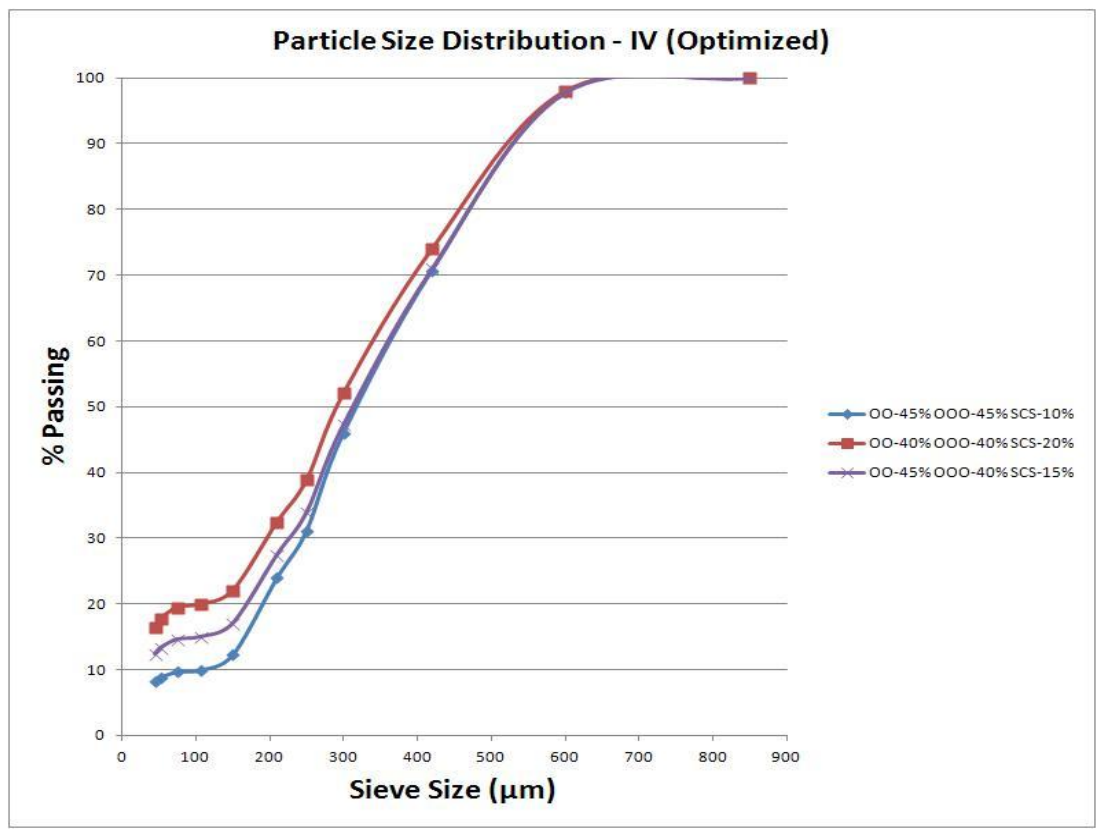

Note: $1 \mu \mathrm{m}=3.937 \times 10^{-5}$ inch

Figure 3.5 Particle size distribution curve - IV (Optimized)

\subsubsection{Mixture Proportions}

After a series of trials in the laboratory with different $\mathrm{w} / \mathrm{cm}$ and admixture contents, the following mixture proportions (Table 3.17) were finally selected for developing HPFRC.

Table 3.17 Mixture proportions (per $\mathrm{m}^{3}$ of concrete) for HPFRC

\section{Quantities}

\begin{tabular}{|c|c|c|c|}
\hline Ingredients & Unit & $\begin{array}{l}\text { Mix-1 (coarser fraction) } \\
(00-45 \%+000-45 \%+ \\
\text { SCS-10\%) }\end{array}$ & $\begin{array}{c}\text { Mix-2 (finer fraction) } \\
(00-40 \%+000-40 \%+ \\
\text { SCS-20\%) }\end{array}$ \\
\hline $\mathrm{w} / \mathrm{cm}$ & - & 0.20 & 0.20 \\
\hline Effective $\mathrm{w} / \mathrm{cm}^{*}$ & - & 0.24 & 0.24 \\
\hline Cement & $\mathrm{Kg}$ & 820 & 820 \\
\hline Sand OO & $\mathrm{Kg}$ & 351 & 312 \\
\hline
\end{tabular}


Sand 000

$\mathrm{Kg}$

351

Sil-co-sil 90

$\mathrm{Kg}$

79

Silica fume

$\mathrm{Kg}$

273

Steel fibers

$\mathrm{Kg}$

157

Water

Glenium 7500

RheoTEC Z-60
$\mathrm{Kg}$

219

60

5
157

273

157

312

219

60

5

* Including water in Glenium 7500 and RheoTEC Z-60 (40\% solid content)

Note: $1 \mathrm{Kg}=2.205 \mathrm{lb} ; 1 \mathrm{~m}^{3}=35.31 \mathrm{ft}^{3}$

The ingredients of HPFRC are shown in Figure 3.6.

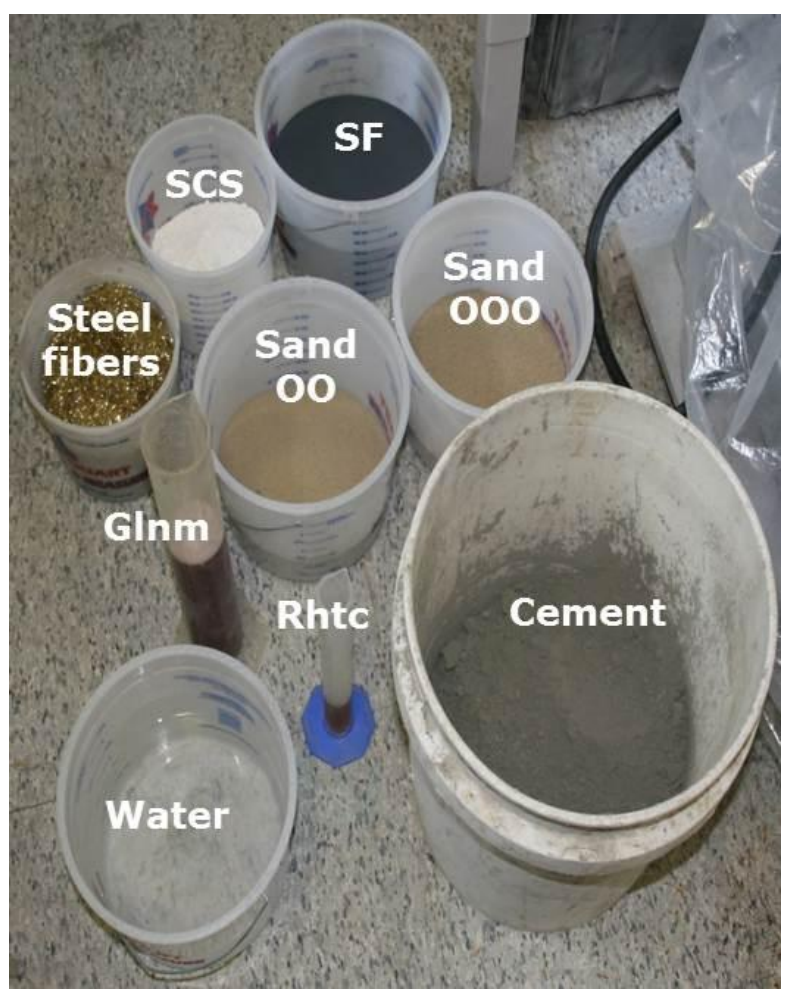

Figure 3.6 Ingredients for HPFRC 


\subsubsection{Mixture Proportioning for NC}

The mixture proportions used for developing NC are shown in Table 3.18.

Table 3.18 Mixture proportions (per $\mathrm{m}^{3}$ of concrete) for NC

\begin{tabular}{ccc}
\hline Ingredients & Unit & Values \\
\hline w/cm & - & 0.50 \\
Effective & - & \\
W/cm* & & \\
Cement & $\mathrm{Kg}$ & 350 \\
Coarse & $\mathrm{Kg}$ & 1035 \\
aggregates & & 776 \\
Sand & $\mathrm{Kg}$ & 175 \\
Water & $\mathrm{Kg}$ & 0.30 \\
MB-AE 90 & $\mathrm{Kg}$ & \\
\hline MB-AE & & \\
\hline
\end{tabular}

* Including water in MB-AE 90 (40\% solid content)

Note: $1 \mathrm{Kg}=2.205 \mathrm{lb} ; 1 \mathrm{~m}^{3}=35.31 \mathrm{ft}^{3}$

\subsection{Mixing Procedure}

\subsubsection{Mixing Procedure for HPFRC}

The mixing procedure for HPFRC is significantly different from NC due to the finer size of the particles. A commercial 3-speed food mixer having a capacity of $28.4 \mathrm{~L}$ (30 qt.) was used to mix HPFRC (Figure 3.7). A constant speed of $91 \mathrm{rpm}$ was maintained throughout the mixing. The mixing procedure is described below:

a. All the constituent materials were weighed.

b. The bowl and the beater were wiped with a wet paper towel. 
c. Three different types of fine aggregates (Sand OO, Sand OOO, and Sil-co-sil 90) and silica fume were added to the bowl and mixed for 3 minutes.

d. Cement was added to the bowl and mixed for 3 minutes.

e. Water was added to the dry mix over a course of 30 seconds and the mixing was continued for 3 minutes.

f. HRWRA (Glenium 7500) and the water retaining admixture (RheoTEC Z-60) were then added and the mixing was continued until the mix turned to a thick paste. This process typically took 2 minutes.

g. Steel fibers were added to the paste and the mixer machine was continued to run (for about 2 minutes) till the fibers were properly dispersed in the matrix.

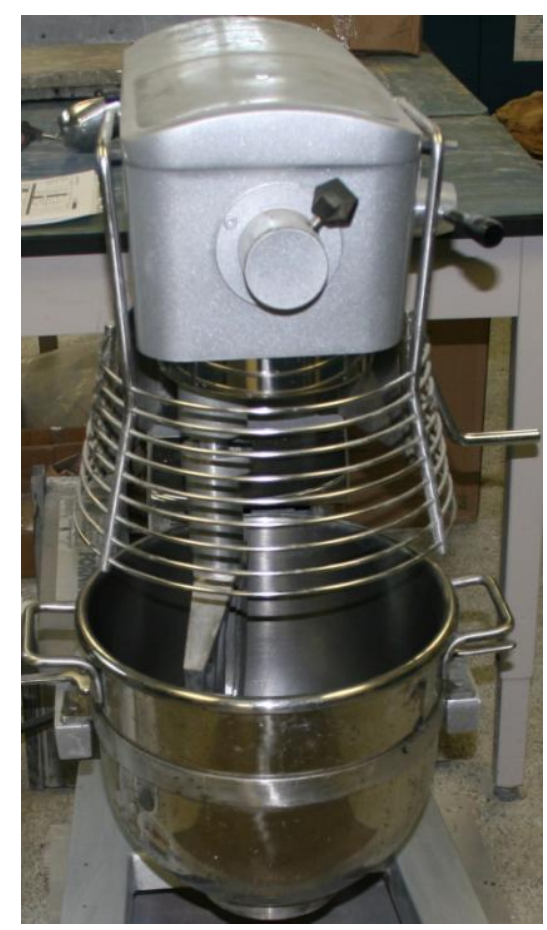

Figure 3.7 Commercial food mixer

\subsubsection{Mixing Procedure for NC}

A variable speed laboratory mixer machine was used to mix the ingredients for NC. The mixing procedure is outlined below:

a. All the constituent materials were weighed.

b. The mixer machine was cleaned and wetted.

c. Air entraining admixture was added to sand and mixed thoroughly.

d. About $34^{\text {th }}$ of the water was added to the mixer machine. 
e. Coarse aggregate was added to the water and mixed for 1 minute.

f. Sand was added to the drum followed by rotation of the mixer machine for another minute.

g. Cement was added to the mixture along with the addition of the remaining water.

h. The mixer was rotated for 3 minutes followed by 3 minutes of rest.

i. The machine was then kept rotating till the desired consistency was achieved. This process typically took 1-2 minute(s).

\subsection{Casting}

\subsubsection{Casting of HPFRC}

As soon as the mixing of HPFRC was completed, the molds were filled with HPFRC with the help of a scoop. Once the molds were filled, a rubber mallet was used to hit the edges of the molds in order to remove the air bubbles. To prevent the steel fibers from breakage, no tamping rod was used while pouring HPFRC. The molds were then placed on a vibrating table for about 30 seconds and the top surfaces were finished off with the help of a trowel.

After the specimens were cast, the exposed area of each specimen was covered with plastic sheet to prevent loss of moisture (as shown in Figure 3.8). Then the specimens were kept in the moist curing room at $23 \pm 2^{\circ} \mathrm{C}\left(73 \pm 3^{\circ} \mathrm{F}\right)$ until demolding.

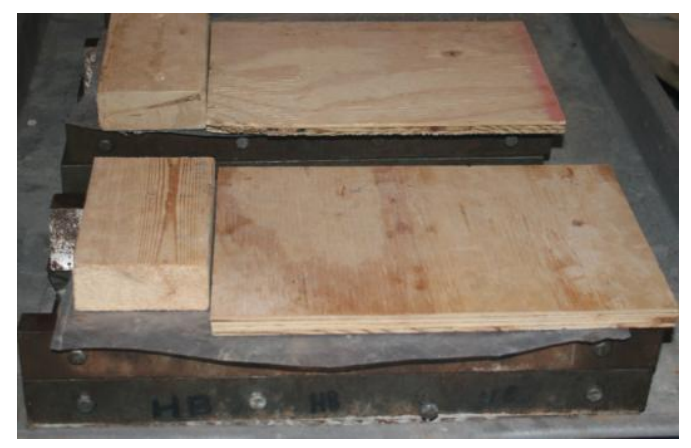

Figure 3.8 Fresh HPFRC Specimens covered with plastic sheet

\subsubsection{Casting of NC}

Immediately after mixing, NC was poured into the molds with the help of a scoop. The tamping of concrete was done with the help of a tamping rod and the edges of the molds were hit with a rubber mallet in order to allow the air bubbles to go out. After that 
the specimens were placed on the vibrating table for 30 seconds. Subsequently, the top surfaces were finished off with a trowel.

After the specimens were cast, the exposed surfaces were covered with wet burlaps and the specimens were kept in the curing room at $23 \pm 2^{\circ} \mathrm{C}\left(73 \pm 3^{\circ} \mathrm{F}\right)$ until demolding.

\subsection{Curing}

\subsubsection{Curing of HPFRC}

24 hours after casting, the specimens were demolded and cured. In order to ascertain the effect of curing temperature on the hardened properties of HPFRC, four different curing conditions were selected in this study. The curing conditions are described below:

\subsubsection{Curing Condition $-35^{\circ} \mathrm{C}-\mathrm{A}$}

In this condition, specimens were wrapped in wet burlap and cured in air at ambient temperature of $35^{\circ} \mathrm{C}\left(95^{\circ} \mathrm{F}\right)$ inside the $\mathrm{Z}-16$ chamber at a relative humidity of $50 \%$.

\subsubsection{Curing Condition $-35^{\circ} \mathrm{C}-\mathrm{W}$}

In this condition, specimens were cured under water in a custom designed temperature controlled double-walled tank (shown in Figure 3.9) at $35^{\circ} \mathrm{C}\left(95^{\circ} \mathrm{F}\right.$ ). The capacity of the water tank was 380 liters (100.4 US gallons) and it was made of molded high density polyethylene. The diameter and height of the tank were $0.6 \mathrm{~m}$ (23.6 inches) and $1.2 \mathrm{~m}$ (47.2 inches), respectively. The tank contained an immersion heater (500 watts $/ 120 \mathrm{~V})$ coated in Teflon and a digital temperature control with $\pm 0.5^{\circ} \mathrm{C}\left( \pm 1^{\circ} \mathrm{F}\right)$ accuracy.

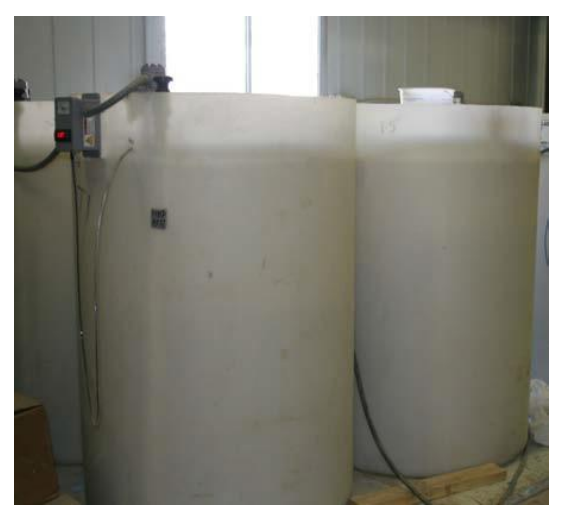

Figure 3.9 Curing tanks 


\subsubsection{Curing Condition $-45^{\circ} \mathrm{C}-\mathrm{W}$}

In this condition, specimens were cured under water in a tank similar to that described in 3.5.1.2 but at a higher temperature of $45^{\circ} \mathrm{C}\left(113^{\circ} \mathrm{F}\right)$.

\subsubsection{Curing Condition $-55^{\circ} \mathrm{C}-\mathrm{W}$}

In this condition, specimens were cured under water in a tank similar to that described in 3.5.1.2 but at a higher temperature of $55^{\circ} \mathrm{C}\left(131^{\circ} \mathrm{F}\right)$.

\subsubsection{Curing of NC}

The specimens for compressive strength test were demolded 24 hours after casting and cured under lime saturated water at $23 \pm 2^{\circ} \mathrm{C}\left(73 \pm 3^{\circ} \mathrm{F}\right.$ ) as per ASTM C192 (Standard Practice for Making and Curing Concrete Test Specimens in the Laboratory).

The specimens for bond study were demolded 24 48 hours (depending on the particular test) after casting and covered with wet burlap until the casting of HPFRC on top of that. 


\section{CHAPTER 4 ISOTHERMAL CALORIMETRY}

This chapter describes the isothermal calorimetry test performed on the HPFRC mortars in order to evaluate the rate of hydration.

\subsection{Summary of Test Method}

Isothermal calorimetry was carried out in accordance with ASTM C1679 (Standard Practice for Measuring Hydration Kinetics of Hydraulic Cementitious Mixtures Using Isothermal Calorimetry).

HPFRC mixtures without the steel fibers were prepared and introduced into an isothermal calorimeter and the output of the calorimeter is evaluated by graphical and mathematical means to determine retarding and accelerating effects of different combinations of materials.

\subsection{Test Procedure}

'TAM Air' calorimeter, manufactured by TA Instruments, was used in this study (shown in Figure 4.1). The sealed ampoule arrangement was followed and the data were collected using the 'TAM Assistant' software which came along with the equipment.

The test was carried out as per the test matrix shown in Table 4.1.

Table 4.1 Test matrix for isothermal calorimetry

\section{No. of samples}

\begin{tabular}{|c|c|c|}
\hline \multirow{3}{*}{$\begin{array}{c}\text { Curing } \\
\text { conditions }\end{array}$} & \multicolumn{2}{|c|}{ No. of samples } \\
\hline & Mix-1 & Mix-2 \\
\hline & (coarser fraction) & (finer fraction) \\
\hline $35^{\circ} \mathrm{C}-\mathrm{A}$ & 2 & 2 \\
\hline $35^{\circ} \mathrm{C}-\mathrm{W}$ & 2 & 2 \\
\hline $45^{\circ} \mathrm{C}-\mathrm{W}$ & 2 & 2 \\
\hline $55^{\circ} \mathrm{C}-\mathrm{W}$ & 2 & 2 \\
\hline
\end{tabular}


The procedure for isothermal calorimetry test is outlined below:

a. The calorimeter was set to the desired temperature 48 hours before the start of the test.

b. On the test day, all the ingredients of HPFRC mixtures, except the steel fibers, were weighed separately.

c. The new experiment wizard was started on the computer.

d. The required channels were selected and the relevant data were entered.

e. Blank ampoules were loaded into the reference channels slowly and carefully, so that the calorimeter was not disturbed because of the vibration arising out of the loading process.

f. The countdown timer, set to 30 minutes, was started and the materials were thoroughly mixed and poured into the ampoules.

g. The ampoules were then loaded into the calorimeter slowly and carefully. The whole process of mixing the materials and loading the ampoules was completed within 30 minutes.

h. The measurement of heat of hydration was started immediately by pressing the "measuring time" button on the software window.

i. The test was continued for 120 hours.

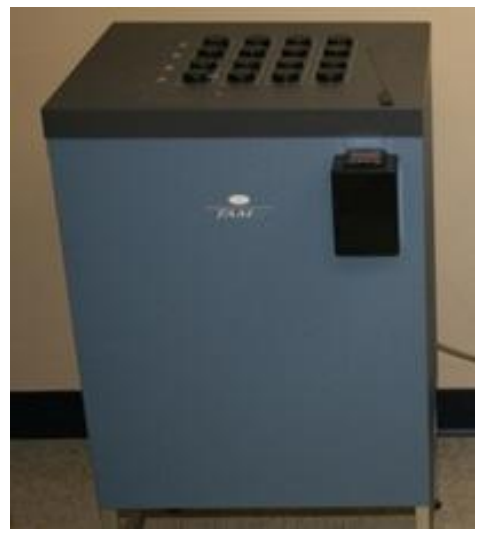

Figure 4.1 TAM Air isothermal calorimeter

\subsection{Test Results and Discussion}

The results obtained from the isothermal calorimetry test are plotted in Figure 4.2, Figure 4.3, and Figure 4.4. 


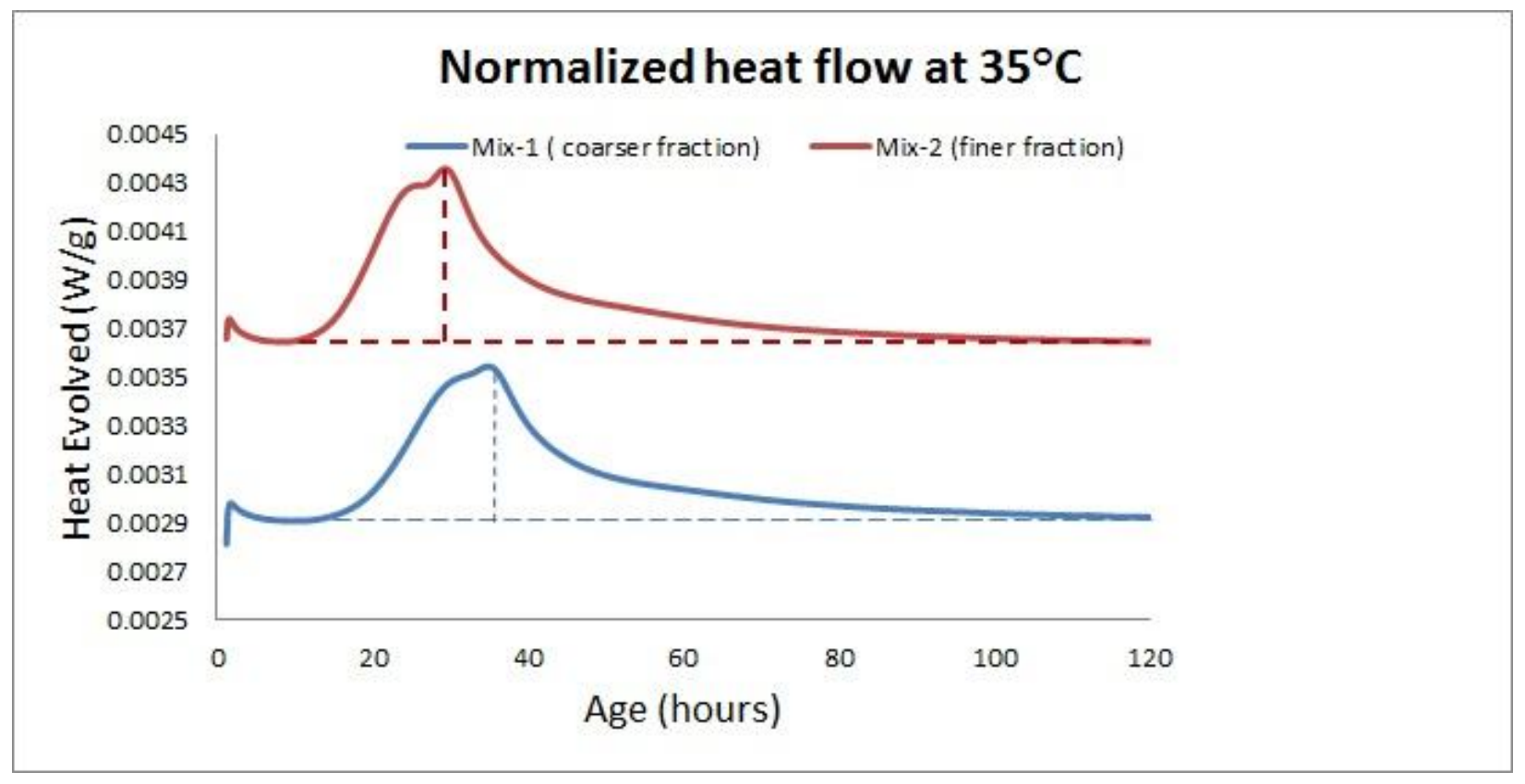

Figure 4.2 Heat evolved vs. time (at $35^{\circ} \mathrm{C}$ )

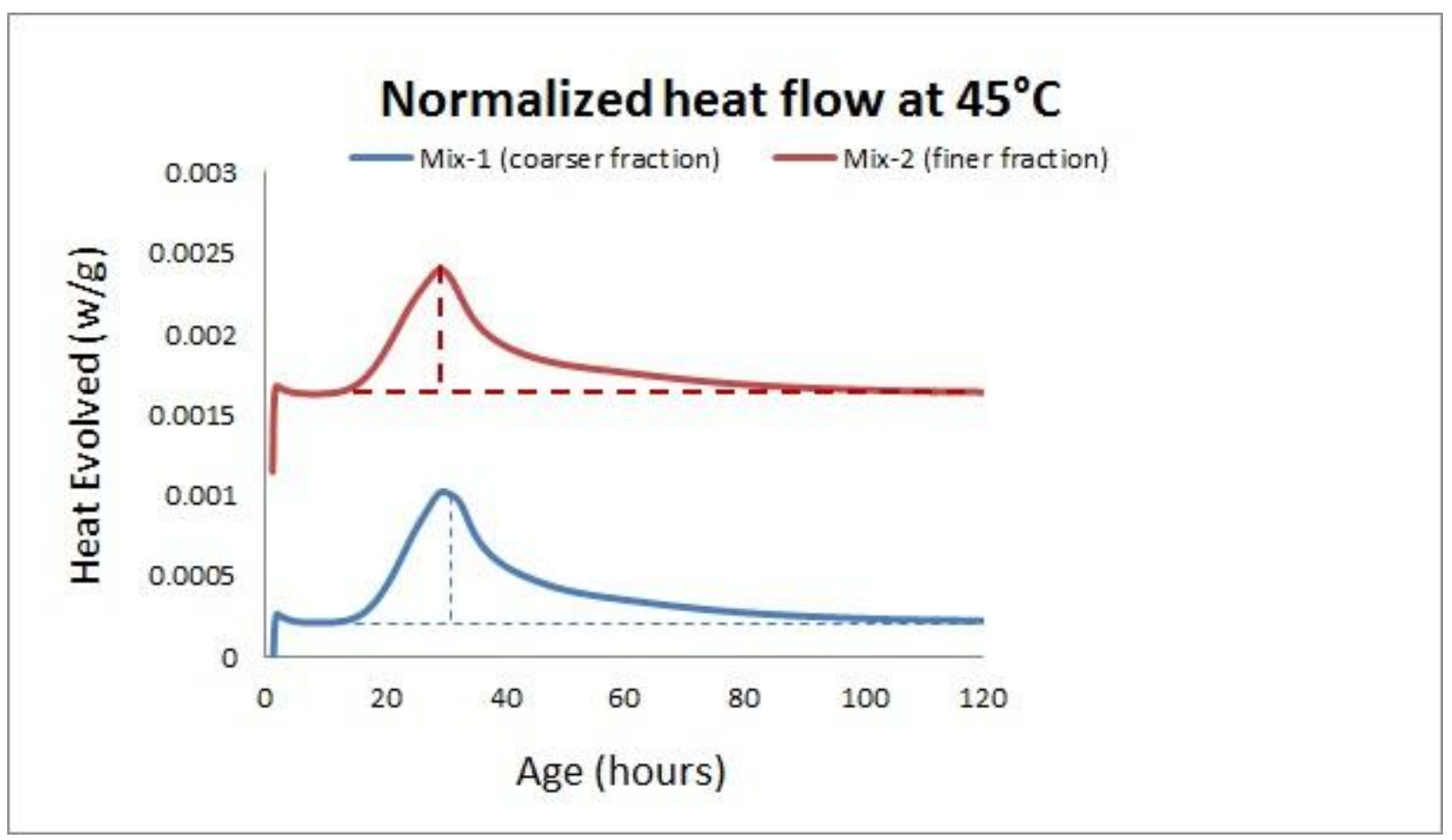

Figure 4.3 Heat evolved vs. time (at $45^{\circ} \mathrm{C}$ ) 


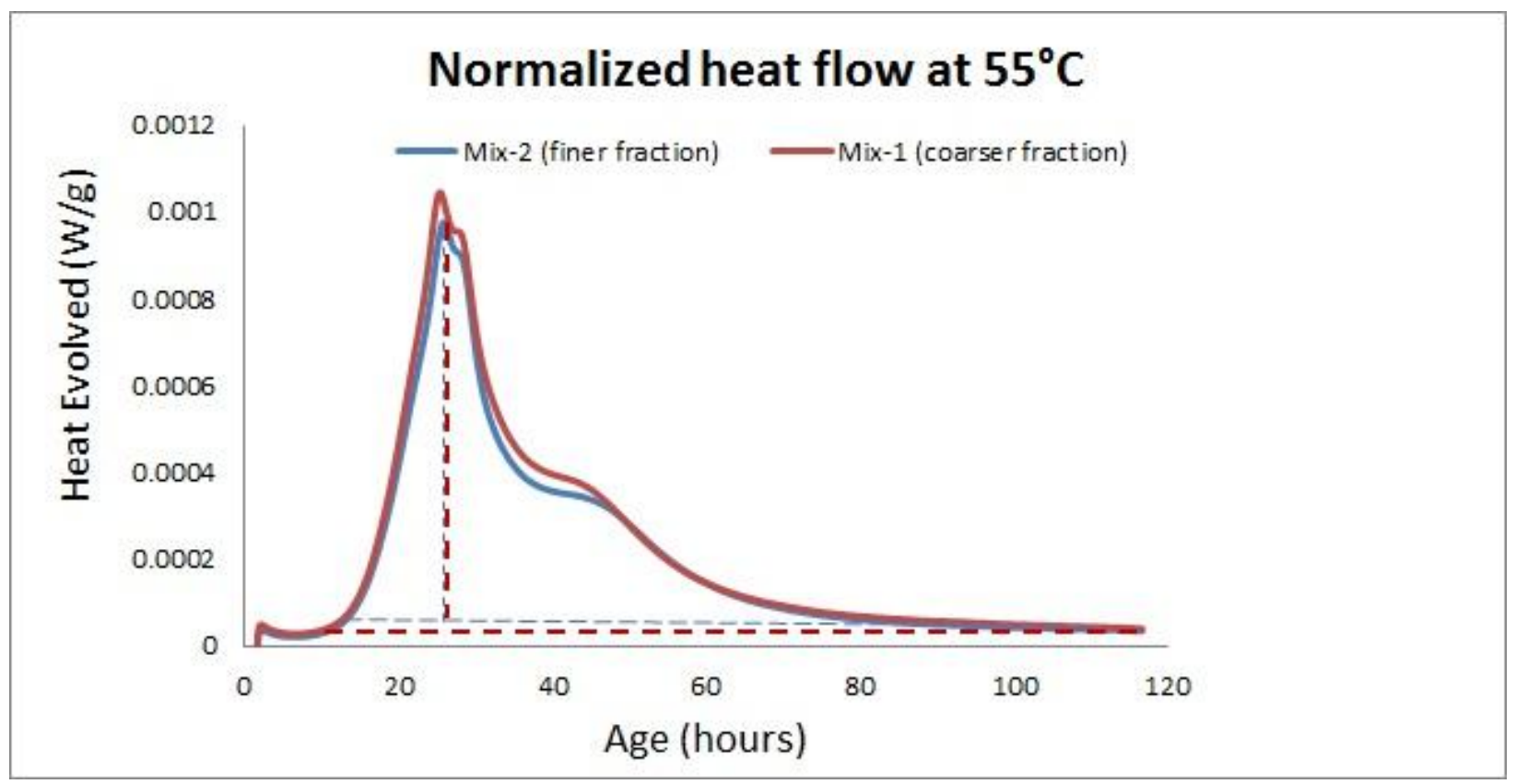

Figure 4.4 Heat evolved vs. time (at $\left.55^{\circ} \mathrm{C}\right)$

From Figure 4.2 and Figure 4.3 it is evident that the peak heat was attained at a much faster rate in case of Mix-2 (finer fraction) than Mix-1 (coarser fraction). Hence, we can infer that the rate of hydration of Mix-2 (finer fraction) was faster than that of Mix-1 (coarser fraction). Also, the total heat evolved was higher in case of Mix-2 (finer fraction) as the area under the curve is much higher.

Figure 4.4 shows that the two curves for evolved heat overlapped with each other due to very fast rate of hydration reaction at such a high temperature $\left(55^{\circ} \mathrm{C}\right)$. The two mixtures behaved almost identically at this temperature. The advantage of this fast rate of hydration reaction is the high early strength gain. But, there is a disadvantage, as well. At such high temperature and fast rate of hydration reaction, the HPFRC matrix will have a tendency to develop shrinkage cracks. The steel fibers will be helpful in bridging these cracks. 


\section{CHAPTER 5 HARDENED PROPERTIES OF HPFRC}

This chapter determines the hardened properties of HPFRC. Both compressive strength and flexural strength of HPFRC were evaluated. The observed values are analyzed and presented in tables/graphs. Based on the compressive and flexural strength results and isothermal calorimetry results (Chapter 4 ), the best performing mixture proportion and two best performing curing conditions were selected for further bond study in Chapter 6 .

\subsection{Compressive Strength of HPFRC}

\subsubsection{Summary of Test Method}

This test method determines the compressive strength of HPFRC by applying a compressive axial load on the cylindrical concrete specimens in accordance with ASTM C39 (Standard Test Method for Compressive Strength of Cylindrical Concrete Specimens).

\subsubsection{Preparation of Specimens}

Eight different combinations based on two mixture proportions (Mix-1 [coarser fraction] and Mix-2 [finer fraction]), as described in Table 3.17, and four curing conditions $\left(35^{\circ} \mathrm{C}-\mathrm{A}, 35^{\circ} \mathrm{C}-\mathrm{W}, 45^{\circ} \mathrm{C}-\mathrm{W}\right.$, and $\left.55^{\circ} \mathrm{C}-\mathrm{W}\right)$, as described in 3.5 .1 , were cast to test the compressive strength of HPFRC. There were four specimens in each group. The test matrix is shown in Table 5.1.

Table 5.1 Test matrix for compressive strength test

\begin{tabular}{ccc}
\hline \multirow{2}{*}{$\begin{array}{c}\text { Curing } \\
\text { conditions }\end{array}$} & Mix-1 & Mix-2 \\
\cline { 2 - 3 } & (coarser fraction) & (finer fraction) \\
\hline $35^{\circ} \mathrm{C}-\mathrm{A}$ & 4 & 4 \\
$35^{\circ} \mathrm{C}-\mathrm{W}$ & 4 & 4 \\
$45^{\circ} \mathrm{C}-\mathrm{W}$ & 4 & 4 \\
$55^{\circ} \mathrm{C}-\mathrm{W}$ & 4 & 4 \\
\hline
\end{tabular}


Plastic cylindrical molds having $76 \mathrm{~mm}\left(3^{\prime \prime}\right)$ diameter and $152 \mathrm{~mm}\left(6^{\prime \prime}\right)$ height were used to cast the concrete. Immediately after casting, the exposed surface of each mold was covered with plastic sheet to prevent loss of moisture. Then the specimens were kept in the moist curing room at $23 \pm 2^{\circ} \mathrm{C}\left(73 \pm 3^{\circ} \mathrm{F}\right)$ for 24 hours. The specimens were demolded 24 hours after casting and cured until 1 day before testing. Tests were conducted at 28 days after casting. The top and bottom surfaces of the cylinders were polished to make them smooth, so that the compressive strength was not lowered due to stress concentration at the ends. Figure 5.1 shows some freshly cast HPFRC specimens for compressive strength test.

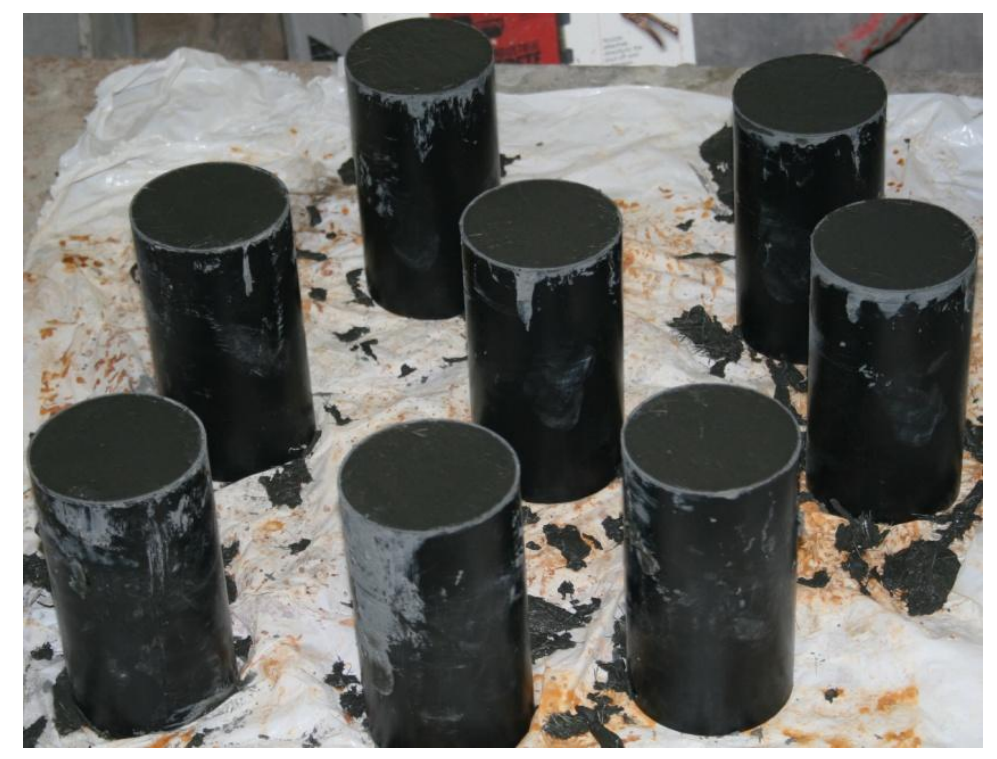

Figure 5.1 Specimens for compressive strength test

\subsubsection{Testing}

A $1000 \mathrm{KN}$ (220 kips) MTS machine with stroke displacement control, was used to measure the compressive strength of the specimens. A constant rate of displacement equal to $0.05 \mathrm{~mm} / \mathrm{sec}(0.002 \mathrm{inch} / \mathrm{sec})$ was used to test the specimens. The MTS machine is shown in Figure 5.2.

The compressive strength is calculated as per the formula shown below:

Compressive strength $=$ (Maximum load carried by the specimen $) /($ Average crosssectional area) 


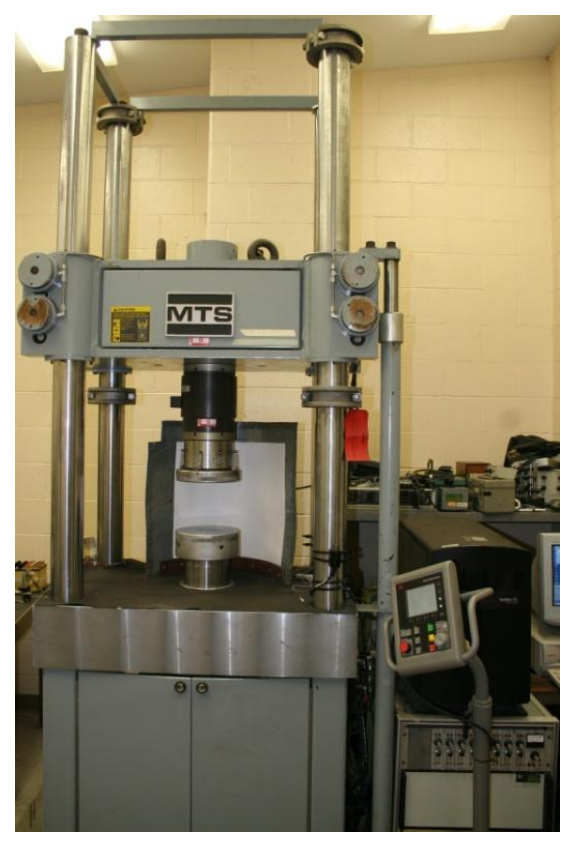

Figure 5.2 MTS machine used for compressive strength test Some specimens failed in compression are shown in Figure 5.3.
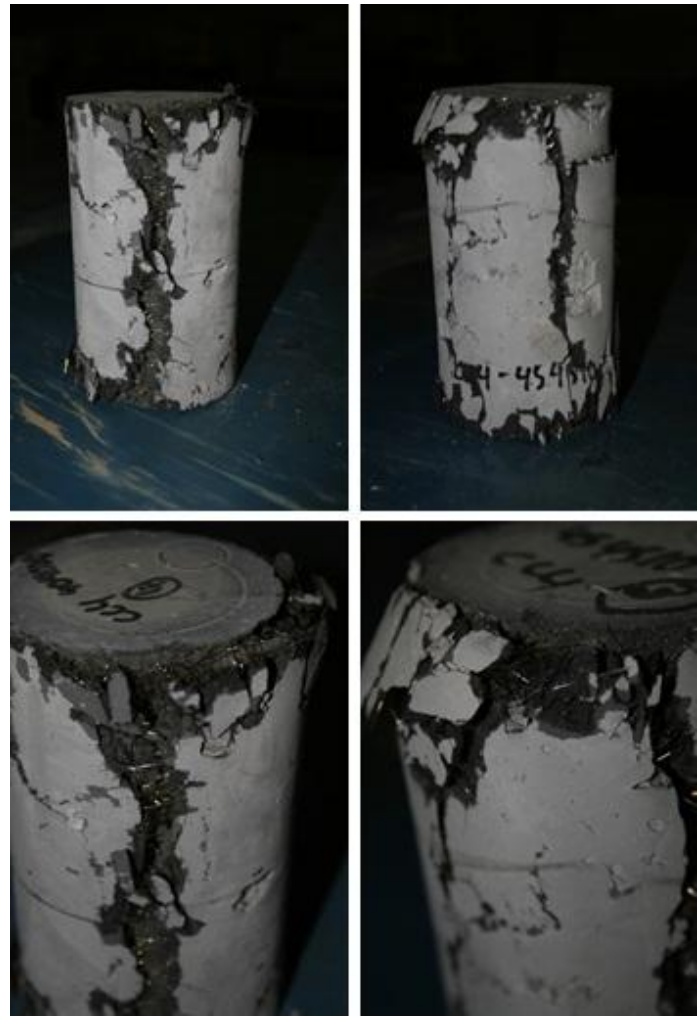

Figure 5.3 Broken specimens (compressive strength test) 


\subsubsection{Results and Discussion}

The average values of compressive strength $\left(f_{c}{ }^{\prime}\right)$ for Mix-1 (coarser fraction) and Mix-2 (finer fraction) are reported in Table 5.2 and Table 5.3, respectively.

Table 5.2 Compressive strength values for Mix-1 (coarser fraction)

\begin{tabular}{ccc}
\hline & \multicolumn{2}{c}{ Mix-1 (coarser fraction) } \\
\cline { 2 - 3 } $\begin{array}{c}\text { Curing } \\
\text { conditions }\end{array}$ & $\begin{array}{c}\text { Compressive } \\
\text { strength } \\
(\mathbf{M P a})\end{array}$ & $\begin{array}{c}\text { Coefficient of } \\
\text { Variation, Cov }\end{array}$ \\
\hline $35^{\circ} \mathrm{C}-\mathrm{A}$ & $97.0 \pm 2.5$ & $\mathbf{( \% )}$ \\
$35^{\circ} \mathrm{C}-\mathrm{W}$ & $101.6 \pm 3.5$ & 6.90 \\
$45^{\circ} \mathrm{C}-\mathrm{W}$ & $102.0 \pm 2.2$ & 4.27 \\
$55^{\circ} \mathrm{C}-\mathrm{W}$ & $105.5 \pm 4.1$ & 7.73 \\
\end{tabular}

Note: $1 \mathrm{MPa}=145 \mathrm{psi}$

Table 5.3 Compressive strength values for Mix-2 (finer fraction)

\begin{tabular}{ccc}
\hline \multirow{2}{*}{$\begin{array}{c}\text { Curing } \\
\text { conditions }\end{array}$} & $\begin{array}{c}\text { Mix-2 (finer fraction) } \\
\text { strength } \\
(\mathbf{M P a})\end{array}$ & $\begin{array}{c}\text { Coefficient of } \\
\text { Variation, Cov }\end{array}$ \\
\cline { 2 - 3 } & $102.6 \pm 3.0$ & $\mathbf{( \% )}$ \\
\hline $35^{\circ} \mathrm{C}-\mathrm{A}$ & $102.9 \pm 3.1$ & 5.94 \\
$35^{\circ} \mathrm{C}-\mathrm{W}$ & $106.5 \pm 1.3$ & 2.38 \\
$45^{\circ} \mathrm{C}-\mathrm{W}$ & $108.6 \pm 1.6$ & 2.88 \\
$55^{\circ} \mathrm{C}-\mathrm{W}$ & & \\
\hline
\end{tabular}

Note: $1 \mathrm{MPa}=145 \mathrm{psi}$ 
The above results are plotted in Figure 5.4 and Figure 5.5 below.

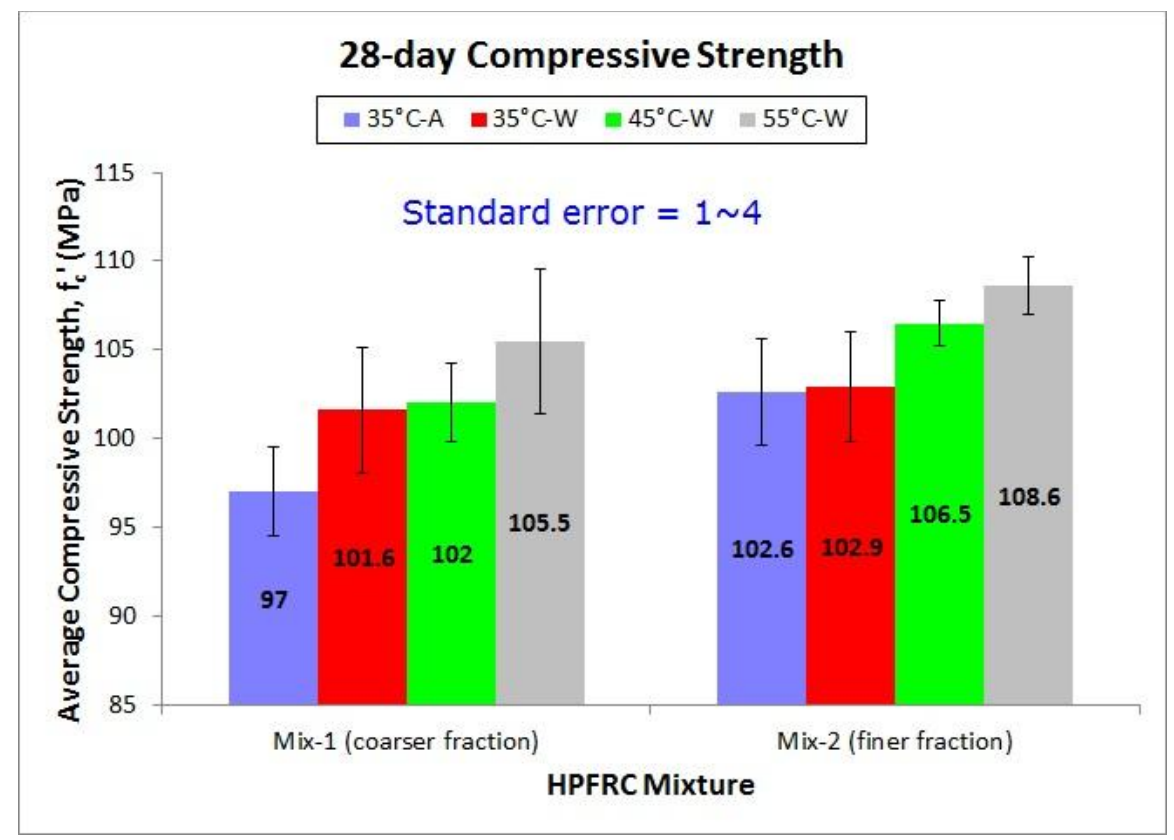

Note: $1 \mathrm{MPa}=145 \mathrm{psi}$

Figure 5.4 Average compressive strength (mixture-wise)

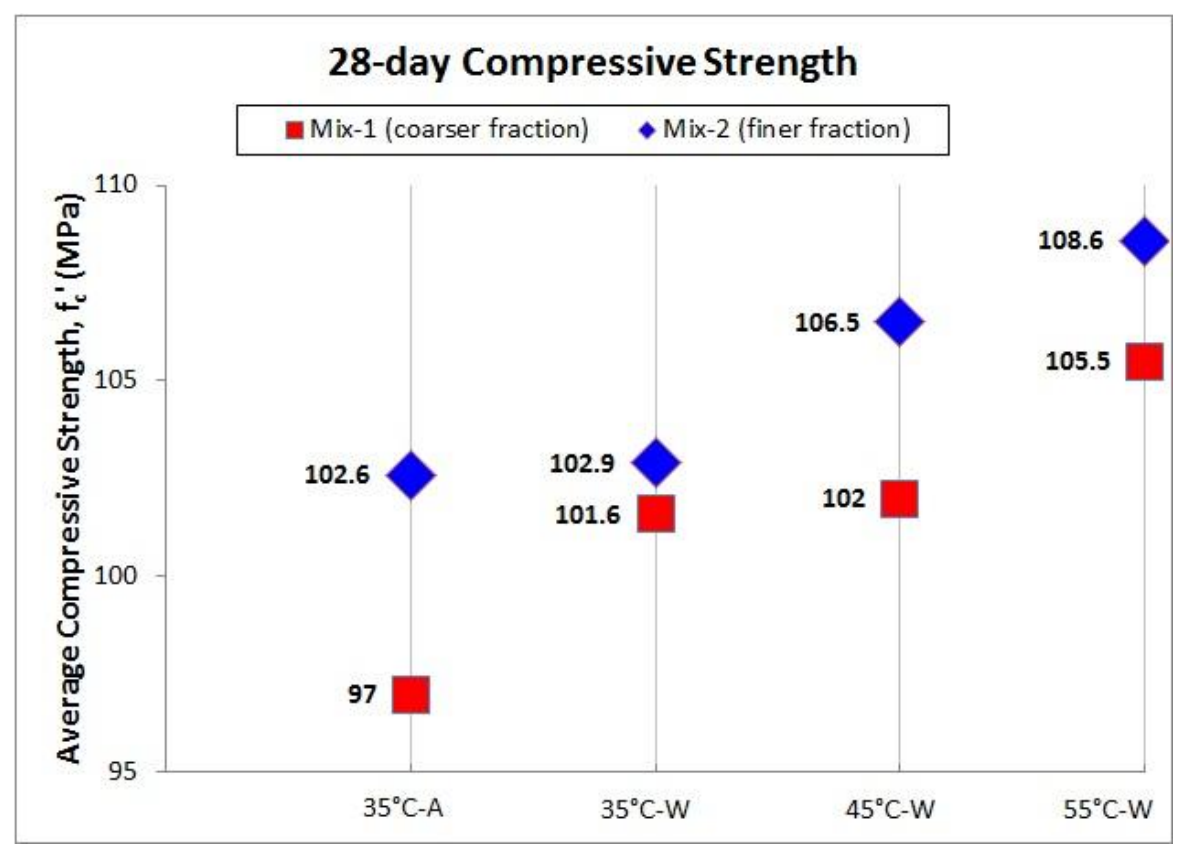

Note: $1 \mathrm{MPa}=145 \mathrm{psi}$

Figure 5.5 Average compressive strength (curing condition-wise) 
Figure 5.4 shows that for Mix-1 (coarser fraction), compressive strength of $55^{\circ} \mathrm{C}-\mathrm{W}$ is greater than that of $45^{\circ} \mathrm{C}-\mathrm{W}$ (by $3.4 \%$ ), $35^{\circ} \mathrm{C}-\mathrm{W}$ (by $3.8 \%$ ), and $35^{\circ} \mathrm{C}-\mathrm{A}$ (by $8.8 \%$ ). Compressive strength of $45^{\circ} \mathrm{C}-\mathrm{W}$ is greater than that of $35^{\circ} \mathrm{C}-\mathrm{W}$ (by $0.4 \%$ ) and $35^{\circ} \mathrm{C}-\mathrm{A}$ (by $5.1 \%$ ). Similarly, for Mix-2 (finer fraction), compressive strength of $55^{\circ} \mathrm{C}-\mathrm{W}$ is greater than that of $45^{\circ} \mathrm{C}-\mathrm{W}$ (by $2.0 \%$ ), $35^{\circ} \mathrm{C}-\mathrm{W}$ (by $5.5 \%$ ), and $35^{\circ} \mathrm{C}-\mathrm{A}$ (by $5.8 \%$ ). Compressive strength of $45^{\circ} \mathrm{C}-\mathrm{W}$ is greater than that of $35^{\circ} \mathrm{C}-\mathrm{W}$ (by $3.5 \%$ ) and $35^{\circ} \mathrm{C}-\mathrm{A}$ (by $3.8 \%$ ). It implies that the same HPFRC mixture cured at a higher temperature has higher compressive strength. Hence, we can infer that curing temperature plays an important role in developing compressive strength of HPFRC; the higher the curing temperature, the better is the compressive strength value.

When the same compressive strength results are plotted in a different way in Figure 5.5, it shows that for a particular curing condition, compressive strength of Mix-2 (finer fraction) is 1.3 to $5.8 \%$ greater than that of Mix-1 (coarser fraction). Since all other conditions were kept same for both the mixtures, we can infer that Mix-2 (finer fraction) has a better packing density than Mix-1 (coarser fraction).

The average coefficient of variation ( $\mathrm{COV}$ ) of all the test results is $5.1 \%$. It indicates that the results are consistent throughout the test.

Table 5.4 compares the maximum value of compressive strength obtained in this study with that of ECC (Yao et al. 2012, Sahmaran and Li 2009), HPFRCC (Kobayashi et al. 2010, Sirijaroonchai et al. 2010, and Kim et al. 2009), and UHPC (Schäfers and Seim 2011). It shows that compressive strength of HPFRC is 65 to $116 \%$ higher than ECC, 29 to $105 \%$ higher than HPFRCC, and 40\% lower than UHPC.

Table 5.4 Comparison of compressive strength

Compressive strength (MPa)

\begin{tabular}{ccccccc}
\hline HPFRC & ECC & ECC & HPFRCC & HPFRCC & HPFRCC & UHPC \\
$\begin{array}{c}\text { (present } \\
\text { study) }\end{array}$ & $\begin{array}{c}\text { (Yao et } \\
\text { al. } \\
\text { 2012) }\end{array}$ & $\begin{array}{c}\text { (Sahmaran } \\
\text { and Li } \\
\text { 2009) }\end{array}$ & $\begin{array}{c}\text { (Kobayashi } \\
\text { et al. 2010) }\end{array}$ & $\begin{array}{c}\text { (Sirijaroonchai } \\
\text { et al. 2010) }\end{array}$ & $\begin{array}{c}\text { (Kim et } \\
\text { al. }\end{array}$ & $\begin{array}{c}\text { (Schäfers } \\
\text { and Seim }\end{array}$ \\
\hline 108.6 & 65.7 & 50.2 & 52.9 & & 2009) & 2011) \\
\hline
\end{tabular}

Note: $1 \mathrm{MPa}=145 \mathrm{psi}$ 


\subsection{Flexural Strength of HPFRC}

\subsubsection{Summary of Test Method}

This test method determines the flexural strength of HPFRC by applying a center point loading on a simple beam resting on two supports in accordance with ASTM C580 (Standard Test Method for Flexural Strength and Modulus of Elasticity of Chemical-Resistant Mortars, Grouts, Monolithic Surfacings, and Polymer Concretes). This ASTM standard was used for flexural strength test because our objective is to use theses HPFRC materials for repairing purposes. The materials tested under this standard, such as, mortars, grouts, and polymer concrete are primarily used for repairing.

\subsubsection{Preparation of Specimens}

Twenty four specimens, based on the test matrix in Table 5.5, were cast to test the flexural strength of HPFRC.

The specimens were cast in steel prismatic molds of $76 \mathrm{~mm}\left(3^{\prime \prime}\right)$ width, $76 \mathrm{~mm}\left(3^{\prime \prime}\right)$ depth and $285 \mathrm{~mm}$ (11.25") length (shown in Figure 5.6). In order to get a good surface of concrete, mold-releasing oil was applied to the molds before casting of concrete. For proper alignment of the steel fibers in the cement matrix, concrete was poured at one end of the prism and allowed to flow to the other end. Demolding of the specimens took place 24 hours after casting. The specimens were cured until 1 day before testing. Testing was carried out at 28 days after casting.

Table 5.5 Test matrix for flexural strength test

\section{No. of specimens}

\section{Curing conditions}

$$
\text { Mix-1 }
$$

(coarser fraction)
Mix-2

(finer fraction)

\begin{tabular}{lll}
\hline $35^{\circ} \mathrm{C}-\mathrm{A}$ & 3 & 3 \\
$35^{\circ} \mathrm{C}-\mathrm{W}$ & 3 & 3 \\
$45^{\circ} \mathrm{C}-\mathrm{W}$ & 3 & 3 \\
$55^{\circ} \mathrm{C}-\mathrm{W}$ & 3 & 3 \\
\hline
\end{tabular}




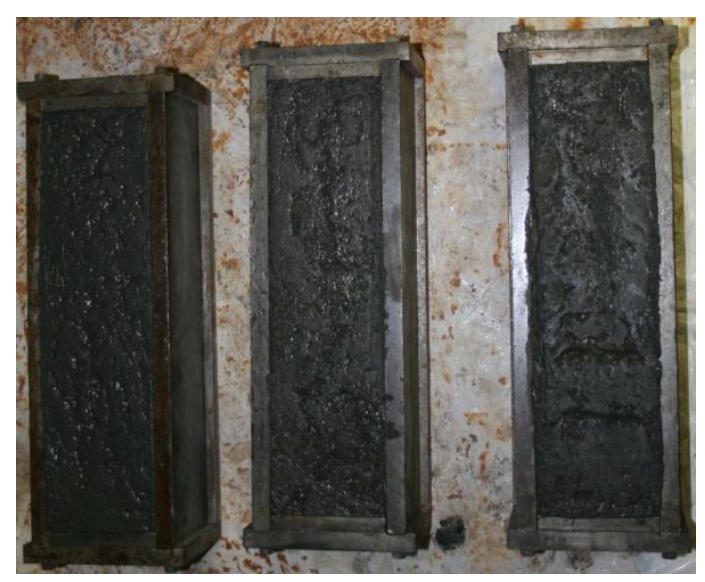

Figure 5.6 Specimens for flexural strength test

\subsubsection{Testing}

Each specimen was tested in flexure as a simple beam in center point loading as per ASTM C580. The specimen rested on two supports and the load was applied midway between the supports.

The same MTS machine used for compressive strength tests (5.1.3) was used for flexural strength test. Each beam specimen had a span of $241 \mathrm{~mm}$ (9.5"). The specimens were loaded at a constant displacement rate of $0.015 \mathrm{~mm} / \mathrm{sec}(0.0006 \mathrm{inch} / \mathrm{sec})$. The test setup has been presented in Figure 5.7.

The flexural strength is calculated as per the formula shown below:

Flexural strength $=(3 \mathrm{PL}) /\left(2 b d^{2}\right)$

where:

$\mathrm{P}=$ the maximum load at or prior to the moment of crack or break, Ibf (or N),

$\mathrm{L}=\operatorname{span}$, in. $(\mathrm{mm})$,

$\mathrm{b}=$ width of beam tested, in. $(\mathrm{mm})$, and

$\mathrm{d}=$ depth of beam tested, in. $(\mathrm{mm})$.

Figure 5.7 shows the test setup for flexural strength test. 


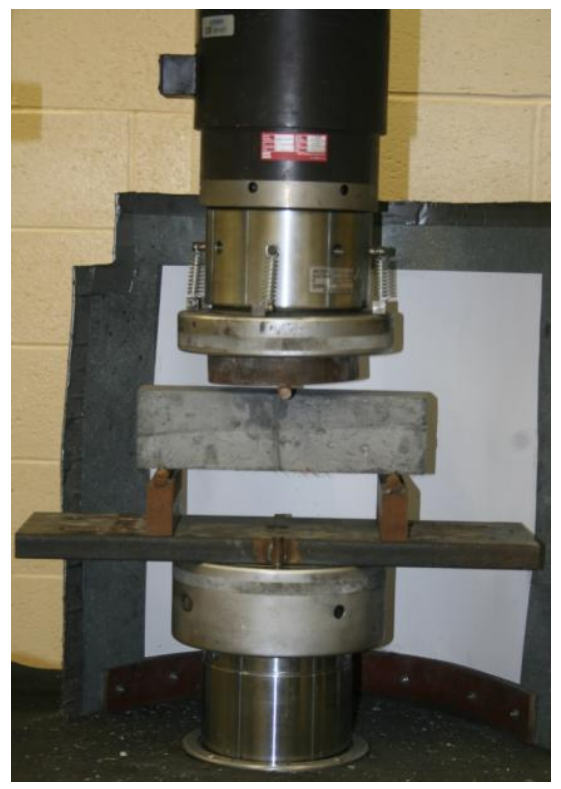

Figure 5.7 Test setup for flexure specimens

Some specimens failed in flexure are shown in Figure 5.8.
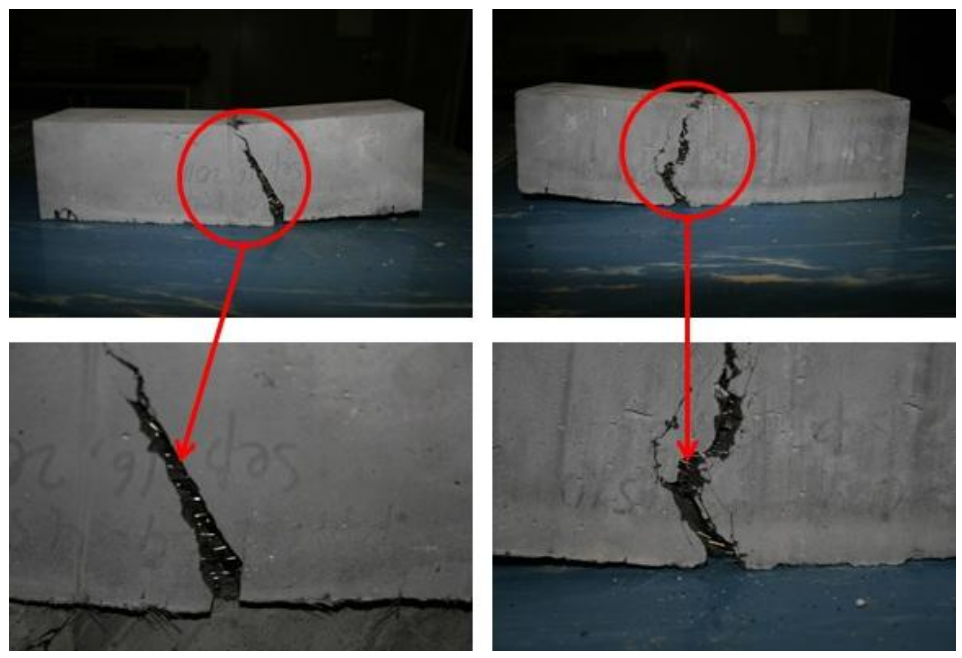

Figure 5.8 Broken specimens (flexural strength test)

\subsubsection{Results and Discussion}

\subsubsection{Flexural Strength}

The average values of modulus of rupture $\left(f_{r}{ }^{\prime}\right)$ calculated from the test results for Mix-1 (coarser fraction) and Mix-2 (finer fraction) are presented in Table 5.6 and Table 5.7, respectively. 
Table 5.6 Flexural strength values for Mix-1 (coarser fraction) Mix-1 (coarser fraction)

$\begin{array}{ccc}\begin{array}{c}\text { Curing } \\ \text { conditions }\end{array} & \text { Flexural strength } & \begin{array}{c}\text { Coefficient of } \\ \text { Variation, cov }\end{array} \\ (\mathrm{MPa}) & \end{array}$

(\%)

$\begin{array}{lcc}35^{\circ} \mathrm{C}-\mathrm{A} & 17.8 \pm 2.7 & 26.23 \\ 35^{\circ} \mathrm{C}-\mathrm{W} & 19.1 \pm 0.9 & 8.11 \\ 45^{\circ} \mathrm{C}-\mathrm{W} & 19.7 \pm 1.7 & 14.54 \\ 55^{\circ} \mathrm{C}-\mathrm{W} & 21.7 \pm 1.0 & 8.24\end{array}$

Note: $1 \mathrm{MPa}=145 \mathrm{psi}$

Table 5.7 Flexural strength values for Mix-2 (finer fraction)

\begin{tabular}{ccc}
\hline \multirow{2}{*}{$\begin{array}{c}\text { Muring } \\
\text { conditions }\end{array}$} & Mlexural strength & $\begin{array}{c}\text { Coefficient of } \\
\text { Variation, CoV }\end{array}$ \\
\cline { 2 - 3 }$(\mathbf{M P a})$ & $\mathbf{( \% )}$ \\
\hline $35^{\circ} \mathrm{C}-\mathrm{A}$ & $20 \pm 1.6$ & 14.14 \\
$35^{\circ} \mathrm{C}-\mathrm{W}$ & $19.4 \pm 1.3$ & 11.75 \\
$45^{\circ} \mathrm{C}-\mathrm{W}$ & $24 \pm 0.7$ & 4.93 \\
$55^{\circ} \mathrm{C}-\mathrm{W}$ & $25.1 \pm 0.9$ & 6.30 \\
\hline $\mathrm{MPa}=145 \mathrm{psi}$ & & \\
\hline
\end{tabular}

Note: $1 \mathrm{MPa}=145 \mathrm{psi}$

The above results are plotted in Figure 5.9 and Figure 5.10. 


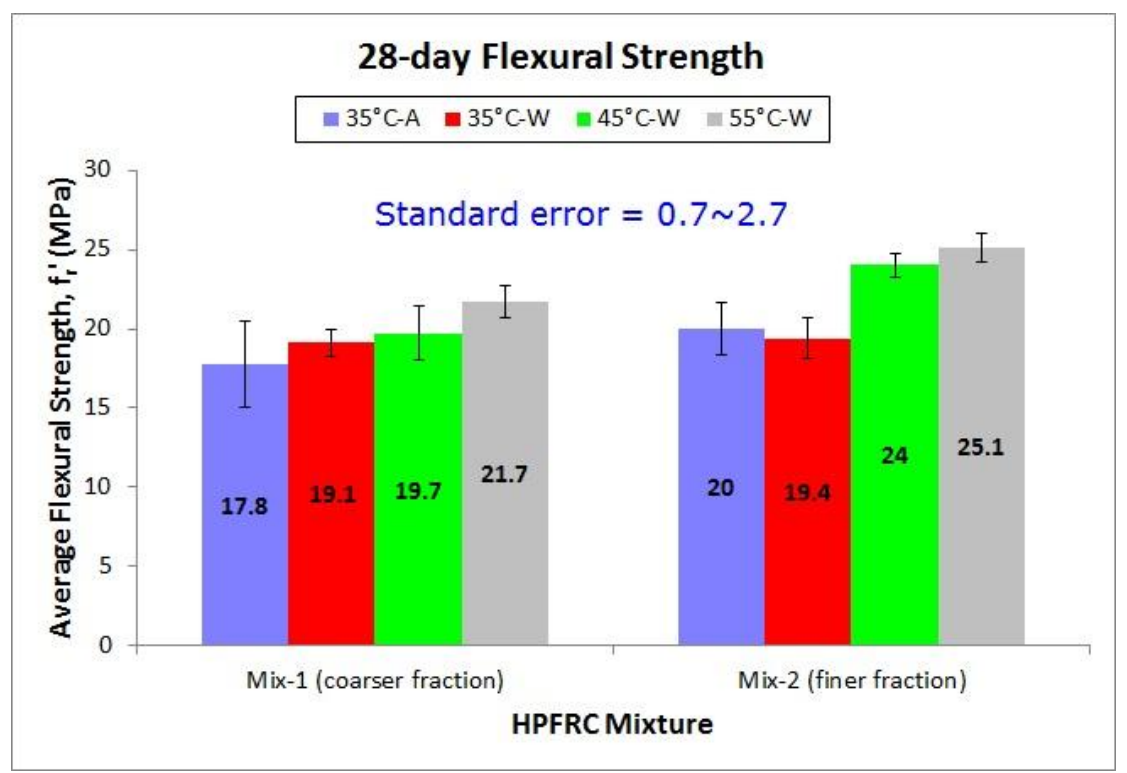

Note: $1 \mathrm{MPa}=145 \mathrm{psi}$

Figure 5.9 Average flexural strength (mixture-wise)

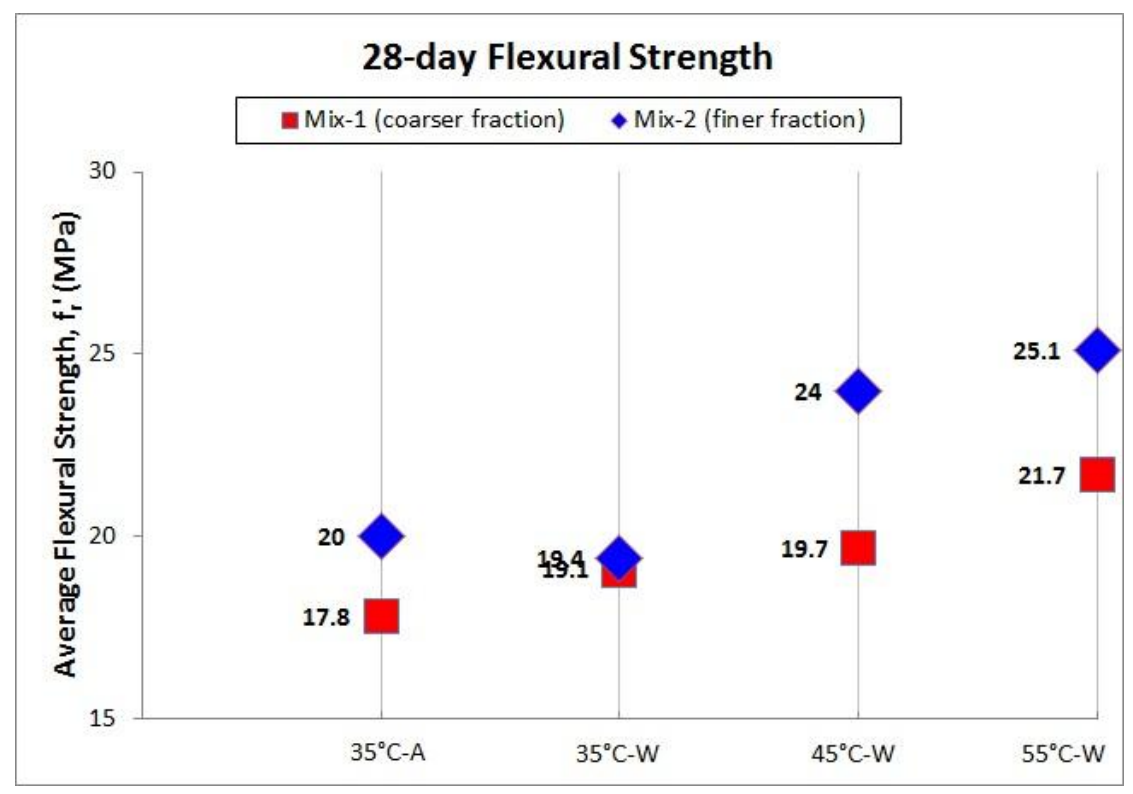

Note: $1 \mathrm{MPa}=145 \mathrm{psi}$

Figure 5.10 Average flexural strength (curing condition-wise)

Figure 5.9 shows that for Mix-1 (coarser fraction), flexural strength of $55^{\circ} \mathrm{C}-\mathrm{W}$ is greater than that of $45^{\circ} \mathrm{C}-\mathrm{W}$ (by $10.2 \%$ ), $35^{\circ} \mathrm{C}-\mathrm{W}$ (by $13.6 \%$ ), and $35^{\circ} \mathrm{C}-\mathrm{A}$ (by $21.9 \%$ ). Flexural strength of $45^{\circ} \mathrm{C}-\mathrm{W}$ is greater than that of $35^{\circ} \mathrm{C}-\mathrm{W}$ (by $3.1 \%$ ) and $35^{\circ} \mathrm{C}-\mathrm{A}$ (by $10.7 \%$ ). Similarly, for Mix-2 (finer fraction), flexural strength of $55^{\circ} \mathrm{C}-\mathrm{W}$ is greater than that 
of $45^{\circ} \mathrm{C}-\mathrm{W}$ (by $4.6 \%$ ), $35^{\circ} \mathrm{C}-\mathrm{W}$ (by $29.4 \%$ ), and $35^{\circ} \mathrm{C}-\mathrm{A}$ (by $25.5 \%$ ). Flexural strength of $45^{\circ} \mathrm{C}-\mathrm{W}$ is greater than that of $35^{\circ} \mathrm{C}-\mathrm{W}$ (by $23.7 \%$ ) and $35^{\circ} \mathrm{C}-\mathrm{A}$ (by $20 \%$ ). It implies that the same HPFRC mixture cured at a higher temperature has higher flexural strength. Hence, we can infer that curing temperature plays an important role in developing flexural strength of HPFRC; the higher the curing temperature, the better is the flexural strength value.

When the same flexural strength results are plotted in a different way in Figure 5.10, it shows that for a particular curing condition, flexural strength of Mix-2 (finer fraction) is 1.6 to $21.8 \%$ greater than that of Mix-1 (coarser fraction). Since all other conditions were kept same for both the mixtures, we can infer that Mix-2 (finer fraction) has a better flexural strength than Mix-1 (coarser fraction).

The average coefficient of variation (COV) of all the test results is less than $12 \%$. It indicates that the results are fairly consistent throughout the test.

Table 5.8 compares the maximum value of flexural strength obtained in the present study with that of DHFRCC (Kim et al. 2008), HPFRCC (Kim 2009), and ECC (Yao et al. 2012). It shows that HPFRC developed in this study has a flexural strength which is comparable to HPFRCC and much higher than ECC (239\%) and deflection hardening FRCC $(92 \%)$.

Table 5.8 Comparison of flexural strength

Flexural strength (MPa)

\begin{tabular}{|c|c|c|c|c|c|}
\hline HPFRC & DHFRCC $^{a}$ & HPFRCC $^{b}$ & HPFRCC $^{c}$ & HPFRCC $^{d}$ & ECC \\
\hline $\begin{array}{l}\text { (present } \\
\text { study) }\end{array}$ & $\begin{array}{c}\text { (Kim et al. } \\
\text { 2008) }\end{array}$ & $\begin{array}{c}\text { (Kim } \\
\text { 2009) }\end{array}$ & (Kim 2009) & $\begin{array}{c}\text { (Kim } \\
2009)\end{array}$ & $\begin{array}{c}\text { (Yao et al. } \\
2012)\end{array}$ \\
\hline 25.1 & 13.08 & 16.78 & 29.42 & 22.21 & 7.4 \\
\hline
\end{tabular}

Note: $1 \mathrm{MPa}=145 \mathrm{psi}$

$\mathrm{a}=$ deflection hardening FRCC with low strength matrix (56 $\mathrm{MPa}$ ) and high strength steel twisted fibers $\left(V_{f}=1.2 \%\right)$

$\mathrm{b}=\mathrm{HPFRCC}$ with high strength matrix $(84 \mathrm{MPa})$ and high strength steel twisted fibers $\left(V_{f}=1.0 \%\right)$ 
$\mathrm{C}=\mathrm{HPFRCC}$ with high strength matrix $(84 \mathrm{MPa})$ and high strength steel twisted fibers $\left(V_{f}=2.0 \%\right)$

$\mathrm{d}=\mathrm{HPFRCC}$ with high strength matrix $(84 \mathrm{MPa})$ and high strength steel hooked fibers $\left(V_{f}=2.0 \%\right)$

\subsubsection{Relative Flexural Strength}

According to ACI 363R (Report on High-Strength Concrete), the ratio of flexural strength $\left(f_{r}{ }^{\prime}\right)$ to square root of compressive strength $\left(\sqrt{ } f_{c}{ }^{\prime}\right)$ represents the flexural strength capacity for a given compressive strength of a material.

The said ratios for different combinations of HPFRC developed in this study are presented in Figure 5.11. It is evident from the plot that the combination 'Mix-2 (finer fraction) $/ 55^{\circ} \mathrm{C}-\mathrm{W}^{\prime}$ has the highest value followed by 'Mix-2 (finer fraction) $/ 45^{\circ} \mathrm{C}-\mathrm{W}^{\prime}$ '. Also the mean value (2.05) is $118 \%$ higher than the value (0.94) specified in ACI 363R for highstrength concrete.

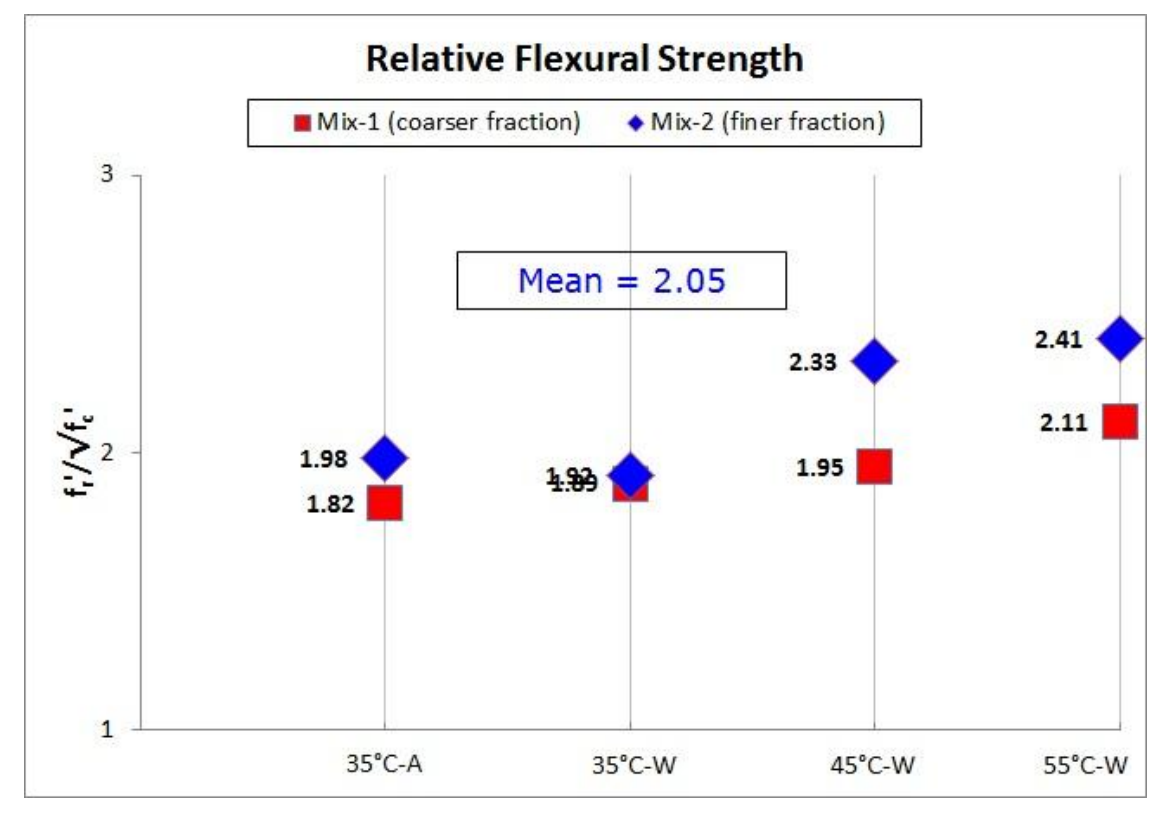

Figure 5.11 Relative flexural strength of HPFRC

\subsubsection{Flexural Toughness}

Flexural toughness is an indication of the energy absorption capacity of a material. It is calculated as the area under the flexural load-deflection curve obtained from a static test of a specimen up to a specified deflection. Its magnitude depends on the geometrical 
characteristics of the test specimen and the loading system. The flexural toughness of HPFRC developed in this study is calculated as follows:

At first, the load vs. deflection curve is plotted in an MS Excel spreadsheet. A typical load-deflection curve is shown in Figure 5.12.

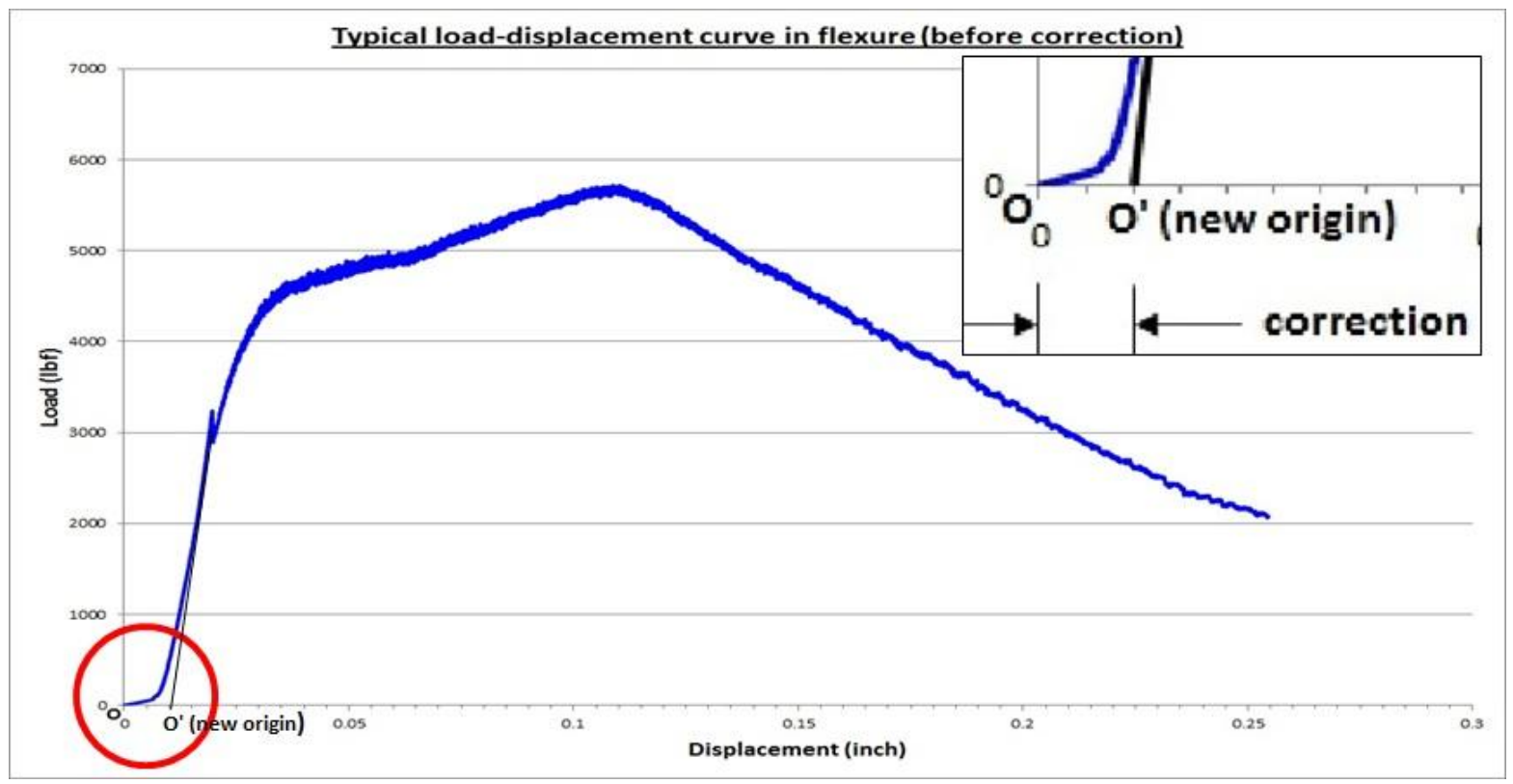

Note: $1 \mathrm{lbf}=4.4 \mathrm{~N} ; 1$ inch $=25.4 \mathrm{~mm}$

Figure 5.12 Typical load-deflection curve (before toe correction)

It can be seen in the above plot that there is a toe region at the beginning, which does not represent a property of the concrete material. This toe region reflects some displacement that might have been caused by misalignment or improper seating of the specimen. In order to correctly obtain the flexural toughness, this error was rectified by extending the straight line portion of the curve to the displacement axis. The point where the straight line intersects the displacement axis is considered as the new origin. All the displacement values are measured from this point. A typical load-deflection curve after toe correction is presented in Figure 5.13.

In the said plot (Figure 5.13) first-peak load is defined as the load value at the first point on the curve, where the slope is zero (ASTM C1609). The peak load is defined as the maximum load on the curve. It is evident from the plot that the peak load is greater than the first peak load. Hence, we can infer that this HPFRC material exhibits deflection 
hardening behavior after the first peak load accompanied by multiple cracking (Naaman and Reinhardt 2006). Deflection softening behavior is exhibited after the peak load.

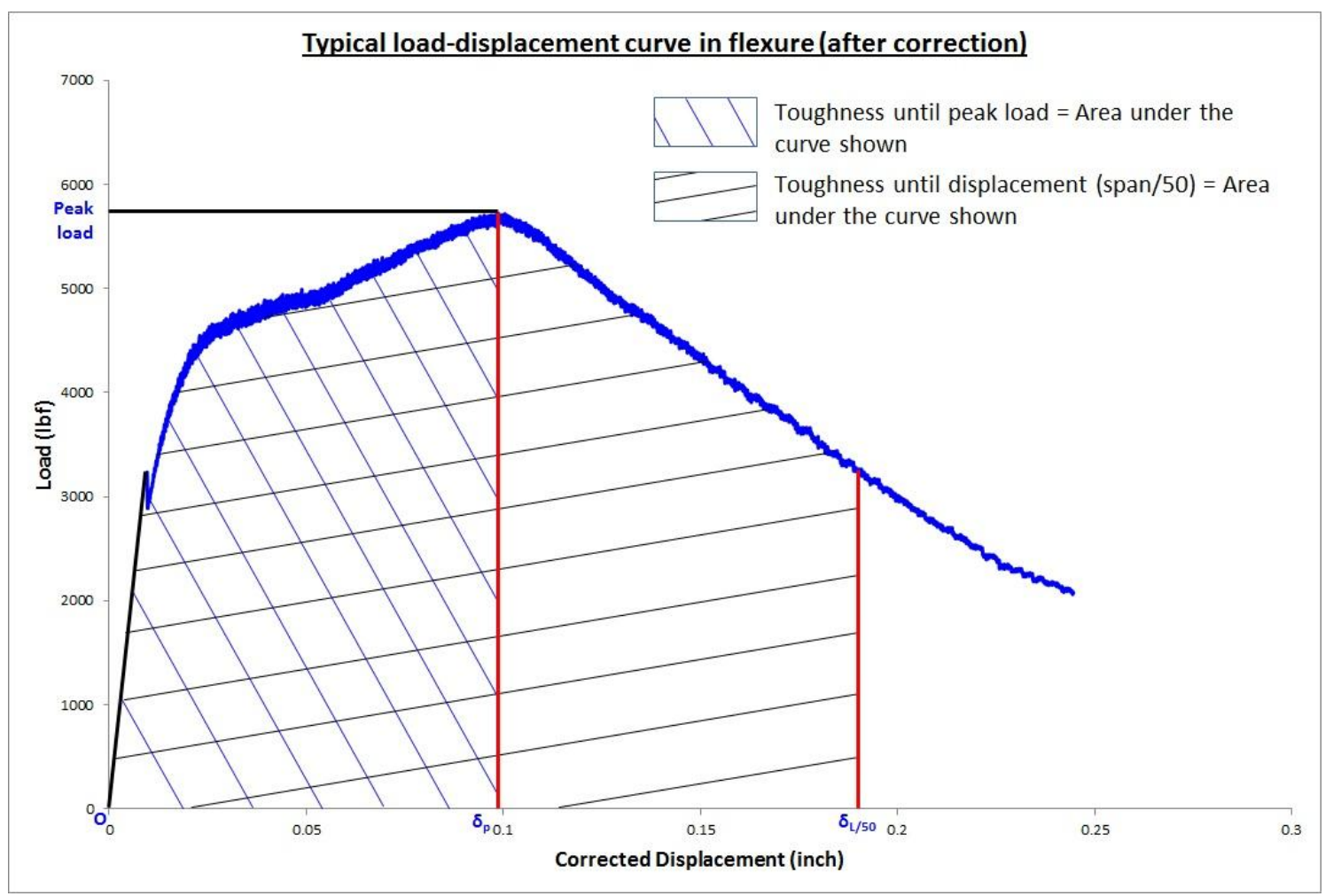

Note: $1 \mathrm{lbf}=4.4 \mathrm{~N} ; 1$ inch $=25.4 \mathrm{~mm}$

Figure 5.13 Typical load-deflection curve (after toe correction)

Toughness of HPFRC is calculated by numerically integrating the above curve up to a specified deflection using trapezoidal rule. ASTM C1609 recommends determination of toughness at span/600 and span/150 points. However, it was found in this study that toughness calculated at these points would have underestimated the true ductile behavior of the material due to its high load-carrying capacity and high deflection behavior. Hence, in the present study, toughness is calculated at displacements corresponding to the peak load $\left(\delta_{\mathrm{p}}\right)$, equal to span/100 $\left(\delta_{\mathrm{L} / 100}\right)$, and span/50 $\left(\delta_{\mathrm{L} / 50}\right)$.

The calculated toughness values are shown in Table 5.9 along with the comparison with published literatures. 
Table 5.9 Comparison of flexural toughness

Flexural toughness $\left(\mathrm{KJ} / \mathrm{m}^{3}\right)$

\begin{tabular}{|c|c|c|c|c|c|c|}
\hline \multicolumn{3}{|c|}{ HPFRC (present study) } & \multicolumn{2}{|c|}{$\begin{array}{c}\text { DHFRCC }^{\text {a }} \text { (Kim et al. } \\
2008)\end{array}$} & \multicolumn{2}{|c|}{ HPFRCC $^{\text {b }}$ (Kim 2009) } \\
\hline Upto $\delta_{p}$ & $\delta_{L / 100}$ & $\delta_{L / 50}$ & Upto $\delta_{p}$ & $\delta_{L / 100}$ & Upto $\delta_{p}$ & $\delta_{L / 100}$ \\
\hline $26 \sim 39$ & $30 \sim 38$ & $50 \sim 73$ & 13 & 33 & $\sim 33$ & $\sim 70$ \\
\hline
\end{tabular}

Note:

$\mathrm{a}=$ deflection hardening FRCC with low strength matrix (56 $\mathrm{MPa}$ ) and high strength steel twisted fibers $\left(V_{f}=1.2 \%\right)$ having specimen size: $100 \times 100 \times 350 \mathrm{~mm}$

$\mathrm{b}=\mathrm{HPFRCC}$ with high strength matrix (84 MPa) and high strength steel twisted fibers $\left(V_{f}=2.0 \%\right)$ having specimen size: $100 \times 100 \times 350 \mathrm{~mm}$

Table 5.9 shows that flexural toughness of HPFRC is comparable to DHFRCC and HPFRCC.

\subsection{Selection for Bond Study}

Based on the results of isothermal calorimetry test, compressive strength test, and flexural strength test, the best performing mixture proportion and curing conditions are selected as follows:

a. Mixture proportion - Mix-2 (finer fraction)

b. Curing conditions $-55^{\circ} \mathrm{C}-\mathrm{W}$ and $45^{\circ} \mathrm{C}-\mathrm{W}$

The above mixture proportion and the two curing conditions were used for further bond study in Chapter 6. 


\section{CHAPTER 6 BOND STRENGTH BETWEEN HPFRC AND NC}

This chapter evaluates the bond strength between HPFRC, as a repair material and NC, as a substrate. Three different experiments, such as, a) Direct Shear Test, b) Slant Shear Test, and c) Pull-off Test, were conducted in order to ascertain the bond strength. The test results are discussed with the help of graphs and tables.

\subsection{Bond Strength by Direct Shear}

\subsubsection{Summary of Test Method}

This test evaluates the bond strength between hardened concrete (NC) and freshly mixed HPFRC by direct shear method.

\subsubsection{Preparation of Specimens}

The butterfly shaped bi-layer specimens used in this study were first used by (Luo 2002) with different overlay materials and later modified by (Sun 2004). The specimens were cast in partitioned steel molds in two layers. The bottom layer, cast with NC, acted as a substrate. The top layer was cast with HPFRC simulating repair material. Thickness of each layer was $38 \mathrm{~mm}\left(1.5^{\prime \prime}\right)$. Figure 6.1 shows a typical bi-layer specimen. A 3-D schematic view and a side view are shown in Figure 6.2 and Figure 6.3, respectively.

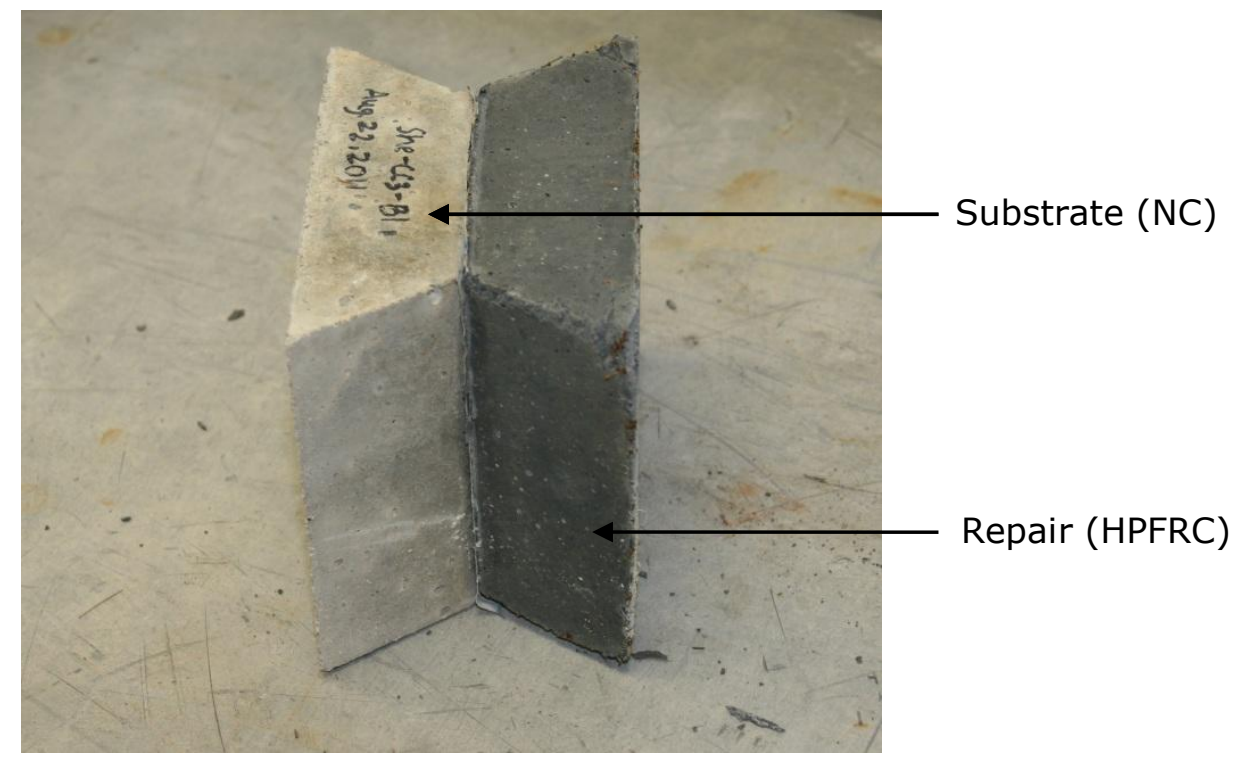

Figure 6.1 Bi-layer specimen for direct shear test 


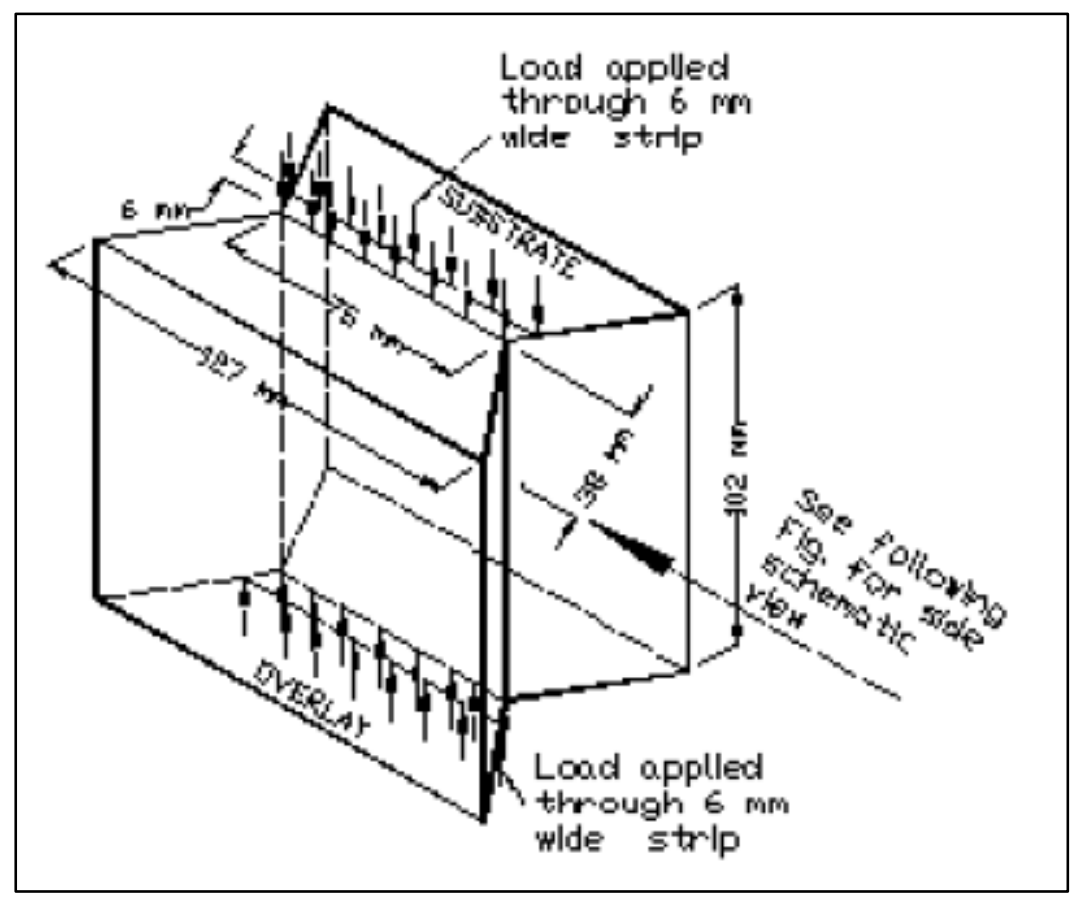

Figure 6.2 Schematic view of specimen with applied loads (from Sun 2004)

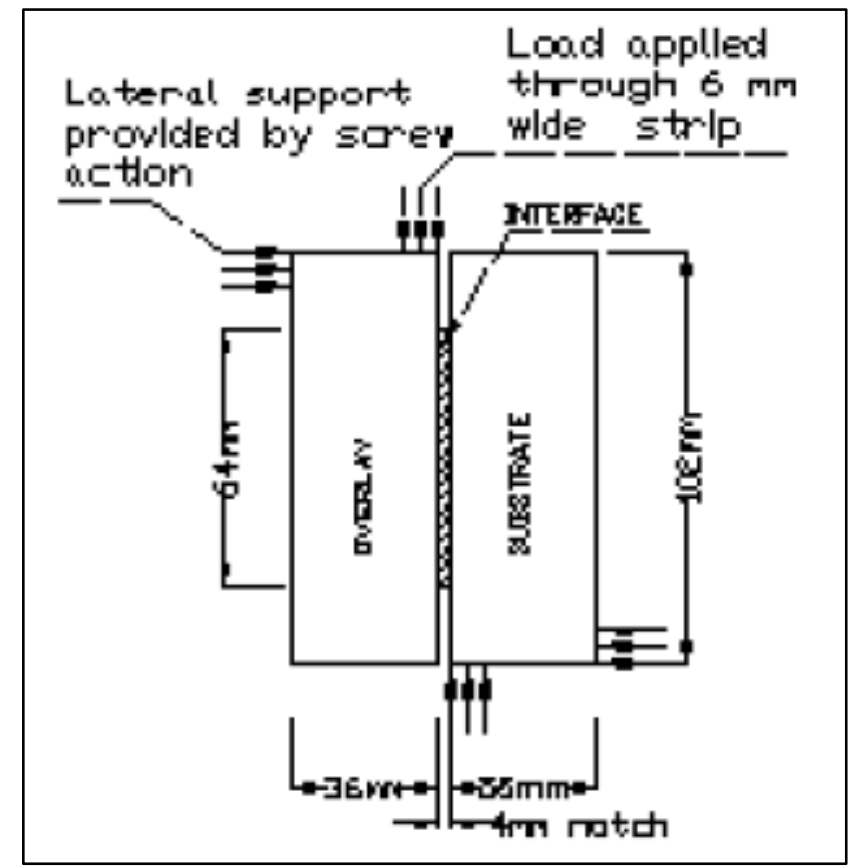

Figure 6.3 Side view of specimen (from Sun 2004)

The procedure for preparation of the test specimens is outlined below:

a. The bottom layer of the partitioned steel mold was assembled first and a mold releasing oil was applied to it in order to get a good concrete surface. 
b. NC was poured into the bottom layer with the help of a scoop and the assembly was kept on a vibrating table for $30 \mathrm{sec}$. The top surface was finished with the help of a trowel. Figure 6.4 shows freshly cast substrate concrete.

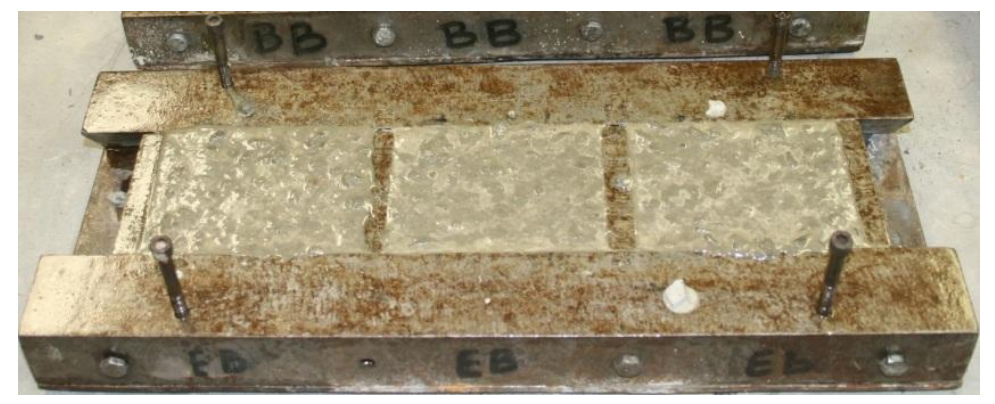

Figure 6.4 Substrate concrete

c. After casting, the substrate concrete was immediately covered with wet burlap and kept in the moist curing room at $23 \pm 2^{\circ} \mathrm{C}\left(73 \pm 3^{\circ} \mathrm{F}\right)$.

d. 5-6 hours after casting, the top surface of the substrate was roughened with the help of a wire brush (as shown in Figure 6.5) in order to improve the bond between the substrate and the repair material. The surface preparation was done simulating CSP-7 of ICRI 03732 (Technical Guideline No. 03732 by International Concrete Repair Institute). After surface preparation, the specimens were again covered with wet burlap and kept in the same curing room.

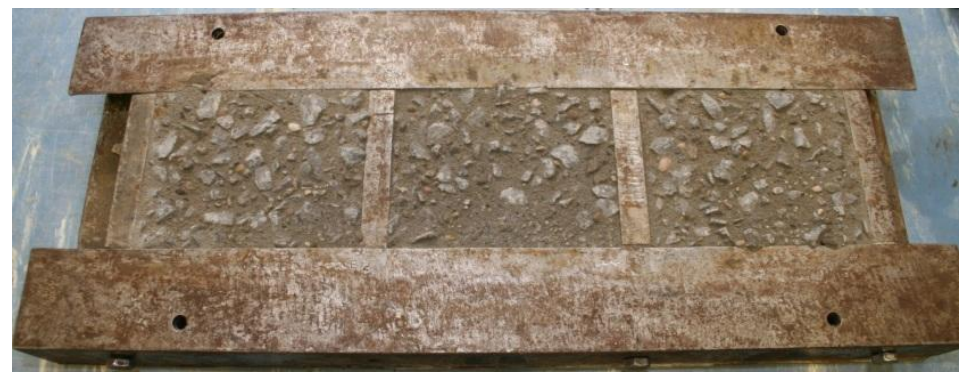

Figure 6.5 Mechanically prepared substrate surface

e. 24 hours after casting, the burlap was removed and the top surface was cleaned thoroughly with water.

f. The exposed area of the top surface of the substrate was reduced to a square section of $50 \mathrm{~mm}\left(2^{\prime \prime}\right)$ side with the help of waterproof duct tape (Figure 6.6). The bond area was reduced in order to ensure the failure through interface for ascertaining interface bond strength. 


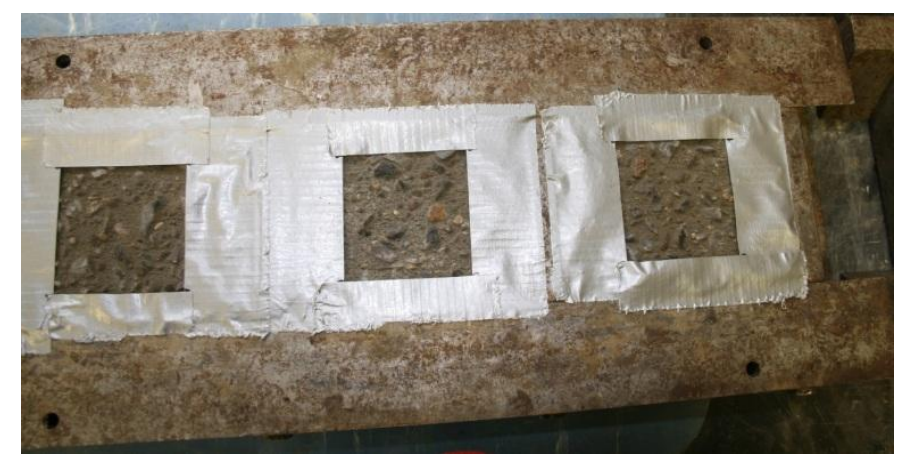

Figure 6.6 Reduced bond area

g. Then the top layer of the steel mold was assembled and made ready for pouring of HPFRC (as shown in Figure 6.7).

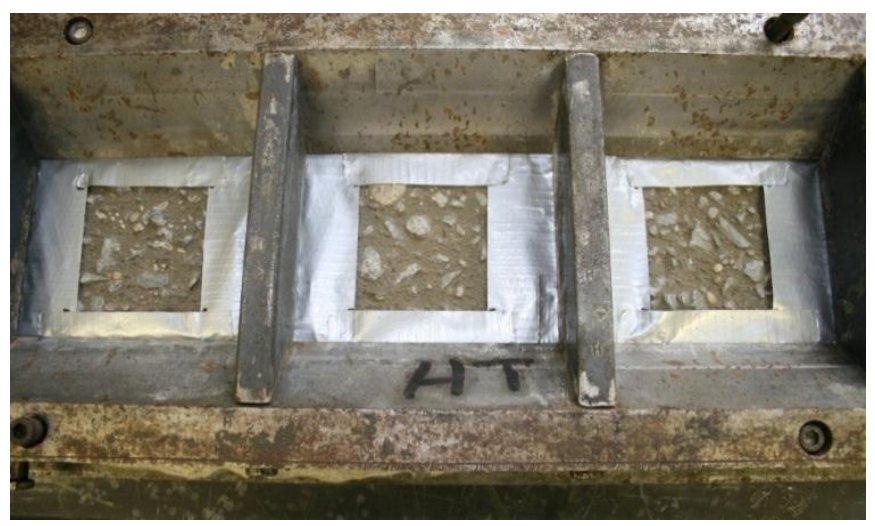

Figure 6.7 Assembled top parts of mold

h. The whole assembly was again covered with wet burlap and kept in the curing room until the casting of repair material.

i. 48 hours after casting of substrate, the top rough surface of the substrate was further treated by one of the following methods before the HPFRC was poured:

- Surface preparation - B1 (Mech): The mechanically roughened surface (prepared in step $d$ above) was cleaned and made ready for casting of HPFRC.

- Surface preparation - B2 (Mech+Epoxy): A two component epoxy-based bonding agent (commercial name - Epoxy.com Product \# 7) was applied to the mechanically roughened substrate at the rate of 60 sq. $\mathrm{ft}$. $\left(6 \mathrm{~m}^{2}\right)$ per gallon. The repair material was then poured while the bonding agent was still tacky.

- Surface preparation - B3 (Mech+Epoxy+Filler): SCS 90 was added to the two component epoxy-based bonding agent described above (15\% by wt. 
of bonding agent) and the slurry was applied to the mechanically roughened substrate surface before pouring of repair material.

j. Figure 6.8 shows finished surface of freshly cast HPFRC repair material. Immediately after casting of the repair material, the exposed area of each bilayer specimen was covered with plastic sheet to prevent loss of moisture (Figure $6.9)$. Then the specimens were kept in the moist curing room at $23 \pm 2^{\circ} \mathrm{C}(73 \pm$ $3^{\circ} \mathrm{F}$ ) for 24 hours.

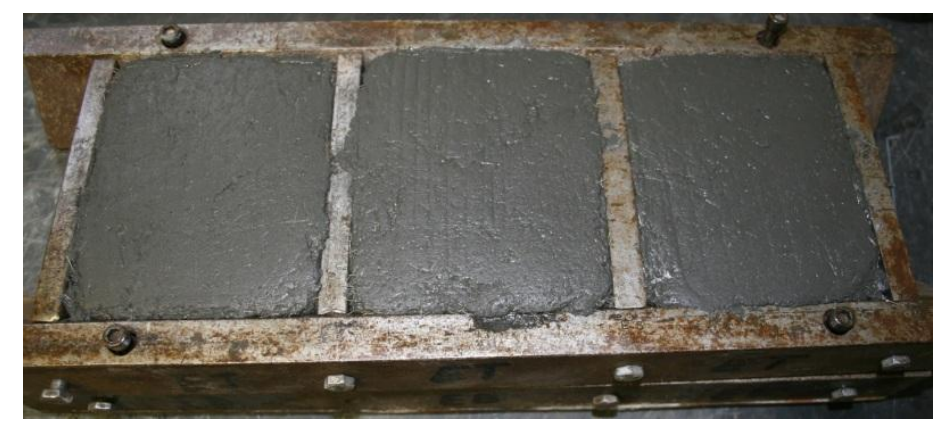

Figure 6.8 Finished surface of repair material (HPFRC)

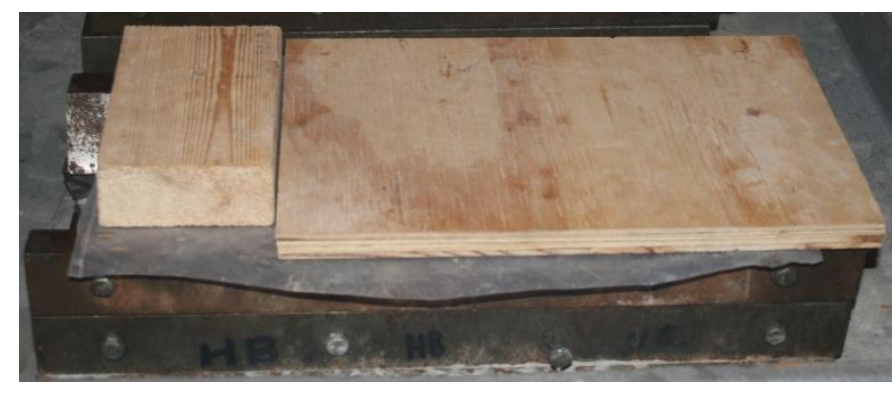

Figure 6.9 Covered specimens

k. 24 hours after casting of HPFRC, the specimens were demolded and cured in the curing tank as per the curing conditions mentioned in the test matrix in Table 6.1 .

I. The specimens were cured for 24 days after casting of HPFRC and then kept in air in the moist curing room until the day of testing. This was done in order to make the interface (specially the epoxy treated interface) dry before testing.

The test matrix for direct shear test is shown in Table 6.1. 
Table 6.1 Test matrix for direct shear test

No. of Specimens

\begin{tabular}{cccc}
$\begin{array}{c}\text { Curing } \\
\text { Conditions }\end{array}$ & $\begin{array}{c}\text { Surface condition-1 } \\
\text { (Mech) }\end{array}$ & $\begin{array}{c}\text { Surface condition-2 } \\
\text { (Mech+Epoxy) }\end{array}$ & $\begin{array}{c}\text { Surface condition-3 } \\
\text { (Mech+Epoxy+Filler) }\end{array}$ \\
\hline $45^{\circ} \mathrm{C}-\mathrm{W}$ & 9 & 9 & 9 \\
$55^{\circ} \mathrm{C}-\mathrm{W}$ & 9 & 9 & 9 \\
\hline
\end{tabular}

\subsubsection{Shear Test Apparatus}

The shear testing apparatus used in the present study was first used by (Luo 2002) and later modified by (Sun 2004). The modification was necessary due to the high shear strength capacity of the specimens prepared by (Sun 2004). The modified fixture was useful in the present study as the shear strength capacity of the test specimens were very high. Through modification, a pure shear condition was achieved.

The original shear testing apparatus used by (Luo 2002) is shown in Figure 6.10 and Figure 6.11. The shear testing apparatus, after modification by (Sun 2004), is shown in Figure 6.12.

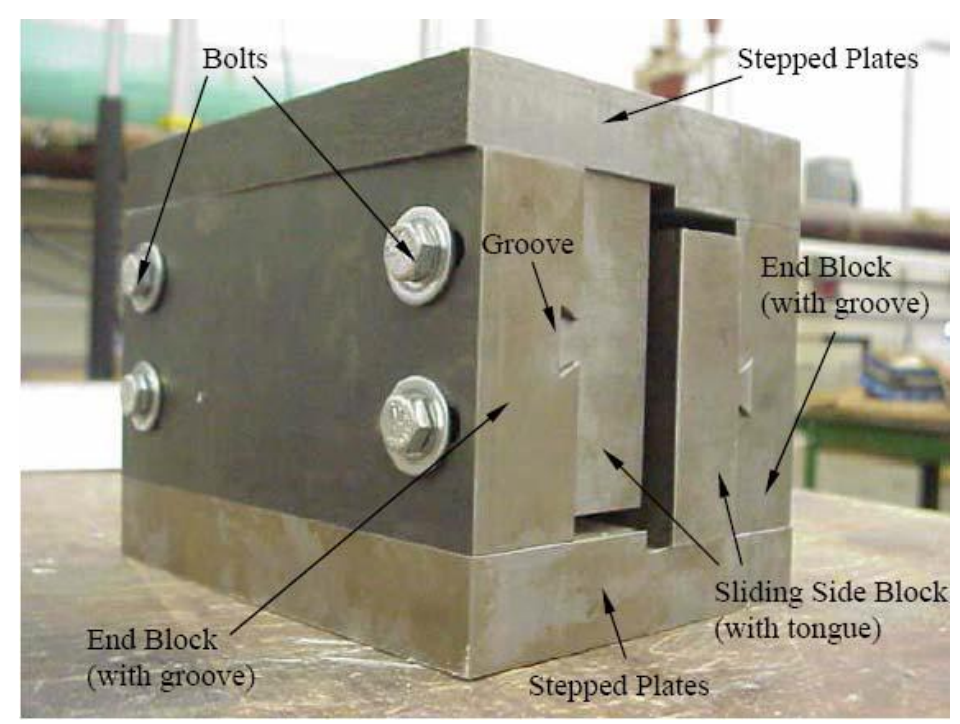

Figure 6.10 Shear testing apparatus (1) used by (Luo 2002) [from Sun 2004] 


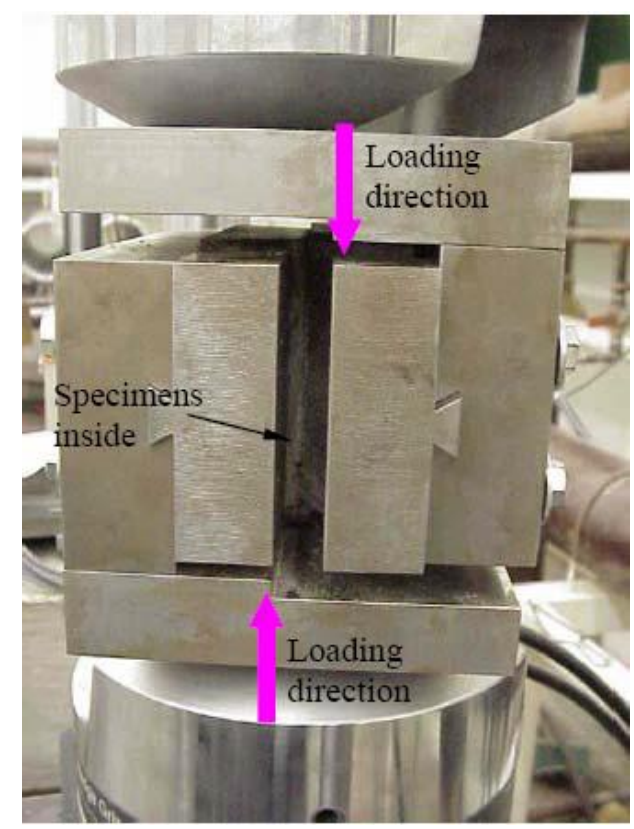

Figure 6.11 Shear testing apparatus (2) used by (Luo 2002) [from Sun 2004]

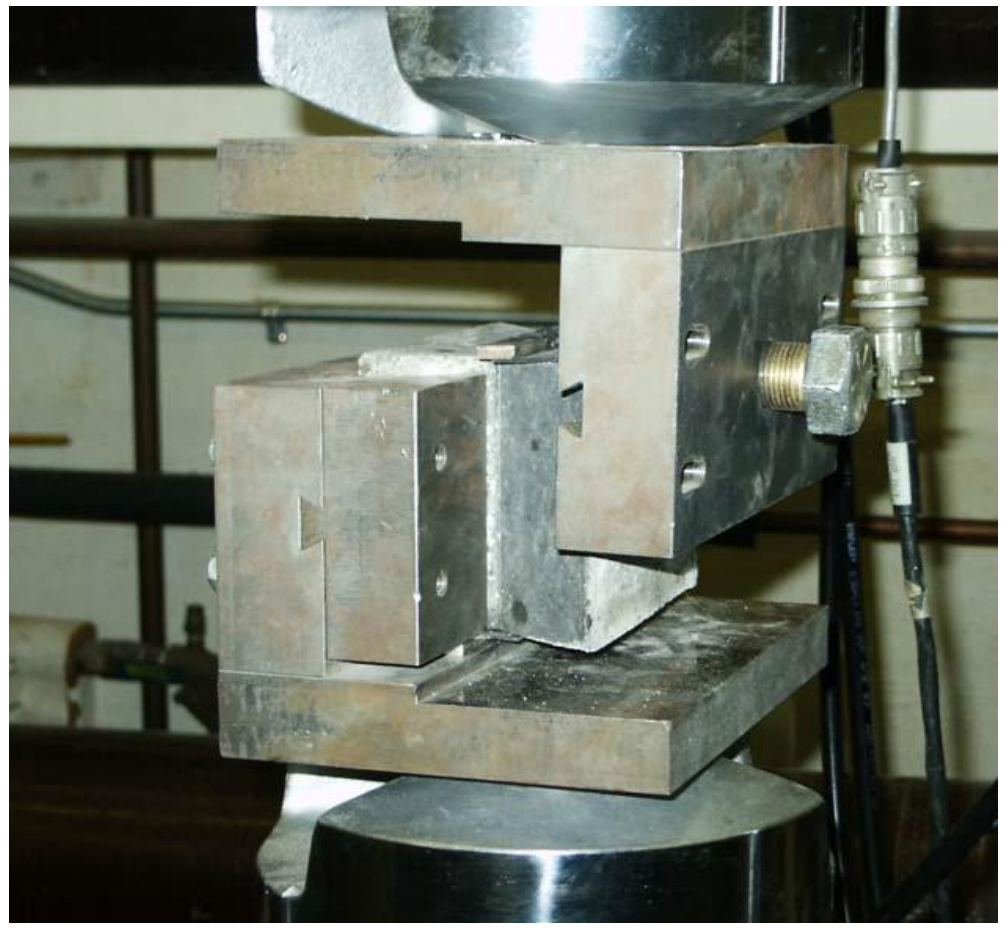

Figure 6.12 Modified shear testing apparatus used by (Sun 2004)

Detailed description of the original apparatus and the modifications thereof are presented by (Luo 2002) and (Sun 2004), respectively. 


\subsubsection{Testing}

An MTS machine with $100 \mathrm{KN}$ (22 kips) load-cell capacity was used to apply uniaxial vertical compressive load. The load wad applied through a steel strip of $6 \mathrm{~mm}\left(1 / 4{ }^{\prime \prime}\right)$ width to reduce the eccentricity and consequently, the moment induced by the load. To avoid local failure of the specimen, all the surfaces of the specimen touching the apparatus were covered with neoprene rubber strip. A steel plate of $3 \mathrm{~mm}\left(1 / \mathrm{s}^{\prime \prime}\right)$ thickness was used to provide support to the back of the specimen with the help of a screw. This prevented the specimen from rotation. Only one edge of the specimen was supported by the steel plate, which could guarantee that there was no compression induced by the support. Figure 6.13 explains the above phenomenon pictorially.

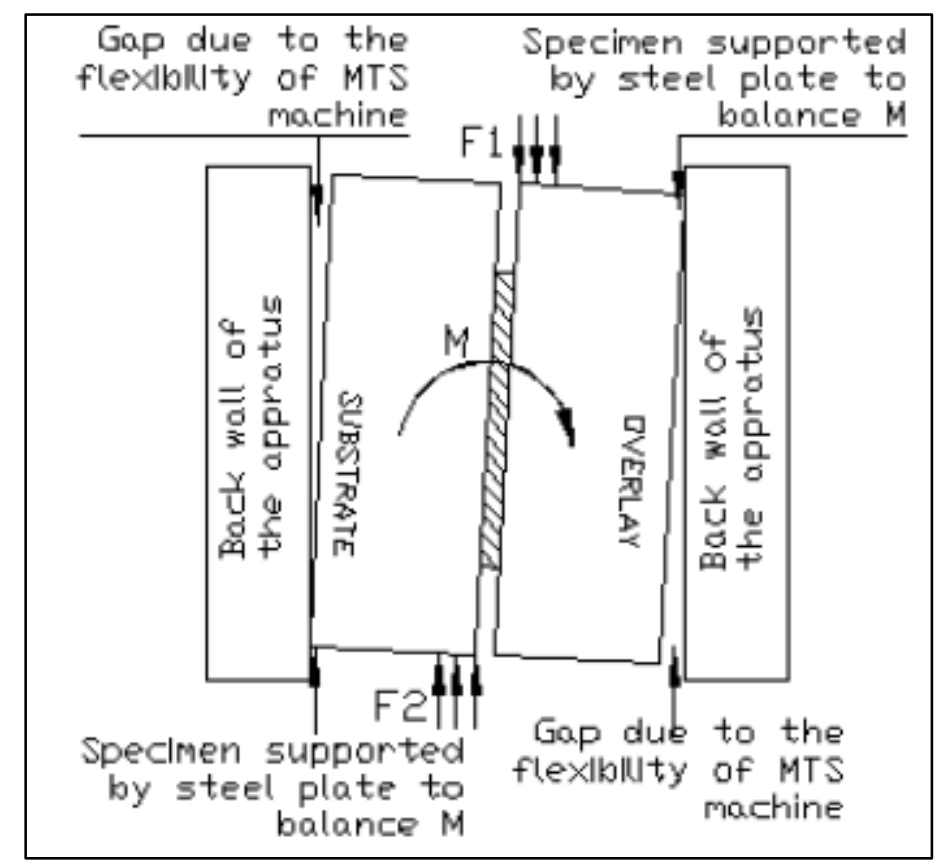

Figure 6.13 Sketch for shear test (from Sun 2004)

The load was applied at the rate of $0.5 \mathrm{~mm} / \mathrm{min}(0.02 " / \mathrm{min})$. The bond strength is calculated by the following formula:

Bond strength $=($ Load at failure $) /($ Bond area $)$

Some representative failure surfaces are shown in Figure 6.14. 


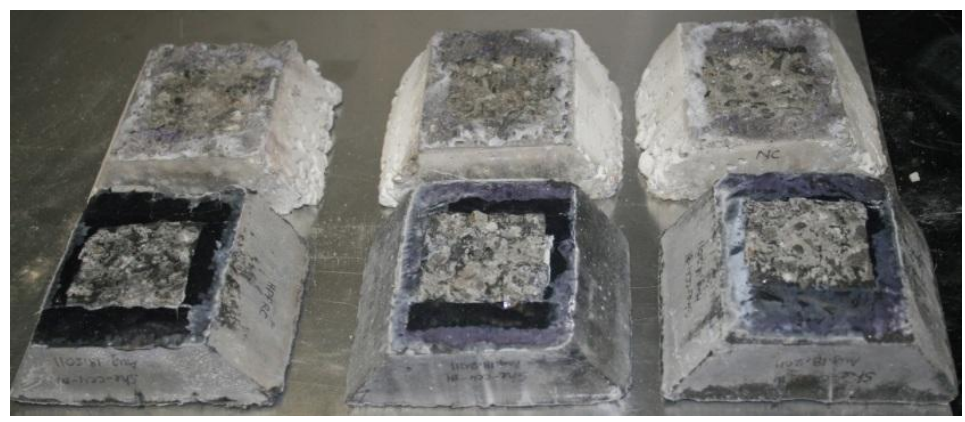

Figure 6.14 Failure surfaces of the test specimens (representative)

\subsubsection{Data Analysis}

\subsubsection{Data Analysis Approach}

A careful observation of the test results (shown in Table A-1) reveals apparent skewness in the data. The data points that deviate markedly from the other members of the sample are detected with the help of descriptive statistics. Such data points are called 'outliers'. "Box Plot", a tool in descriptive statistics, is used to detect the outliers. The "Box Plot" is explained in the following paragraph.

\subsubsection{Box Plot}

A box plot is a convenient way of graphically presenting groups of numerical data through five numbers: the smallest observation $\left(D_{\min }\right)$, lower quartile $\left(Q_{1}\right)$, median $\left(Q_{2}\right)$, upper quartile $\left(Q_{3}\right)$, and the largest observation $\left(D_{\max }\right)$. A box plot may also show the outlier(s), if there is any. $\mathrm{Q}_{1}$ and $\mathrm{Q}_{3}$ are the $25^{\text {th }}$ and $75^{\text {th }}$ percentiles respectively. The main advantage of using box plot is that it displays differences between populations without making any assumption of the underlying statistical distribution. The spacing between different parts of the box indicates the degree of dispersion and skewness in the data. A typical box plot is shown in Figure 6.15. 


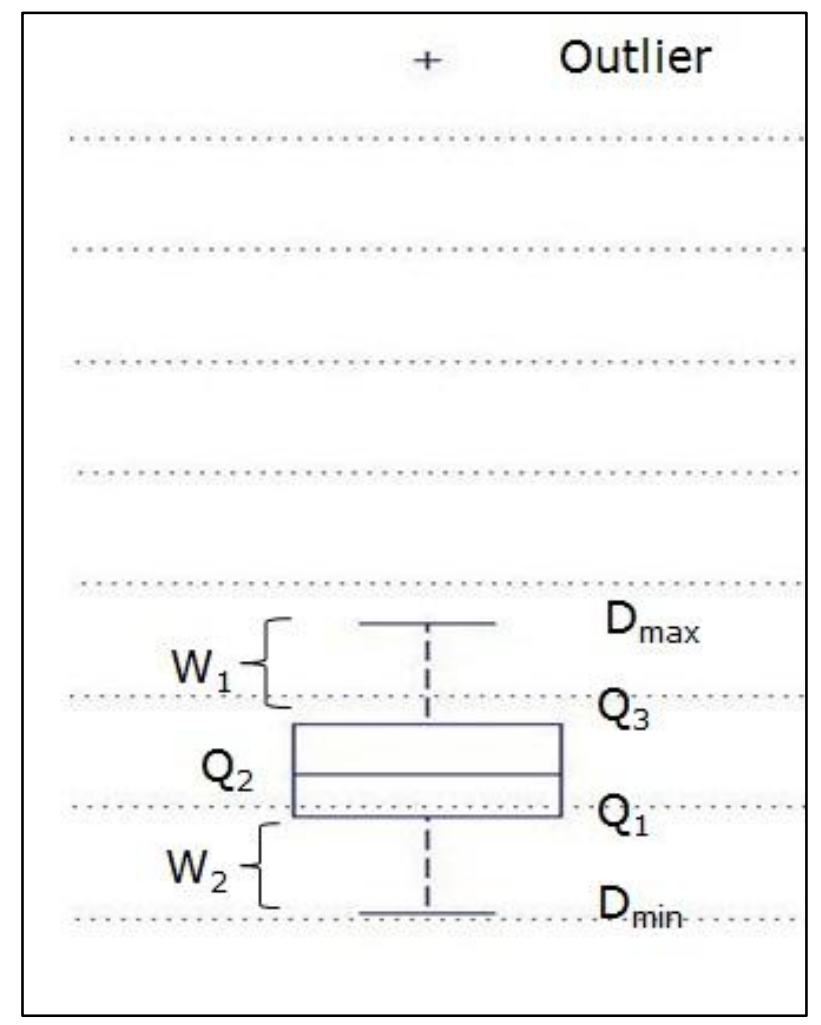

Figure 6.15 A typical box plot

The difference between $Q_{3}$ and $Q_{1}$ is called Inter Quartile Range (IQR). The lines extending from either edge of the box to the sample maximum and sample minimum are called whiskers (denoted as $W_{1}$ and $W_{2}$, respectively). Generally, $W_{1}=Q_{3}+w\left(Q_{3}-Q_{1}\right)$ and $\mathrm{W}_{2}=\mathrm{Q}_{1}-\mathrm{W}\left(\mathrm{Q}_{3}-\mathrm{Q}_{1}\right)$. ' $\mathrm{W}$ ' is the whisker coefficient, which can be varied to increase or decrease the whisker lengths.

\subsubsection{Data Analysis using Box Plot}

In the present study, the value of $\omega$ is considered as 1.5 , which corresponds to $\pm 2.7 \sigma$ and 99.3 coverage if the data was normally distributed (MathWorks 2011). A MATLAB code (MathWorks 2011) is written to create the box plot and detect the outliers. The code is shown in Appendix A. The box plot is shown in Figure 6.16. 


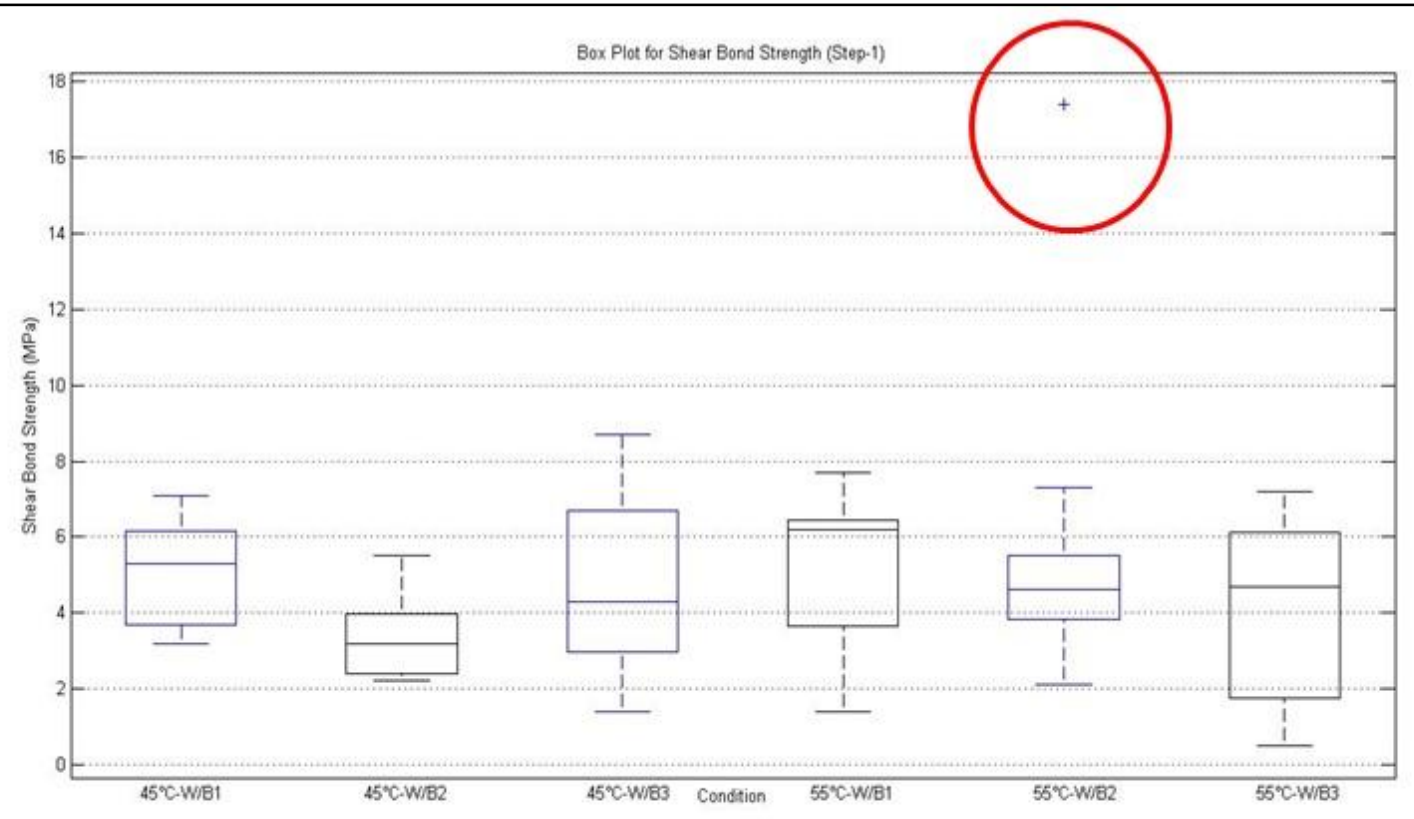

Figure 6.16 Box plot (step-1)

It is evident from the above plot that there is indeed an outlier in the data set. Hence, another box plot is created with the data set excluding the outlier. The plot is shown in Figure 6.17.

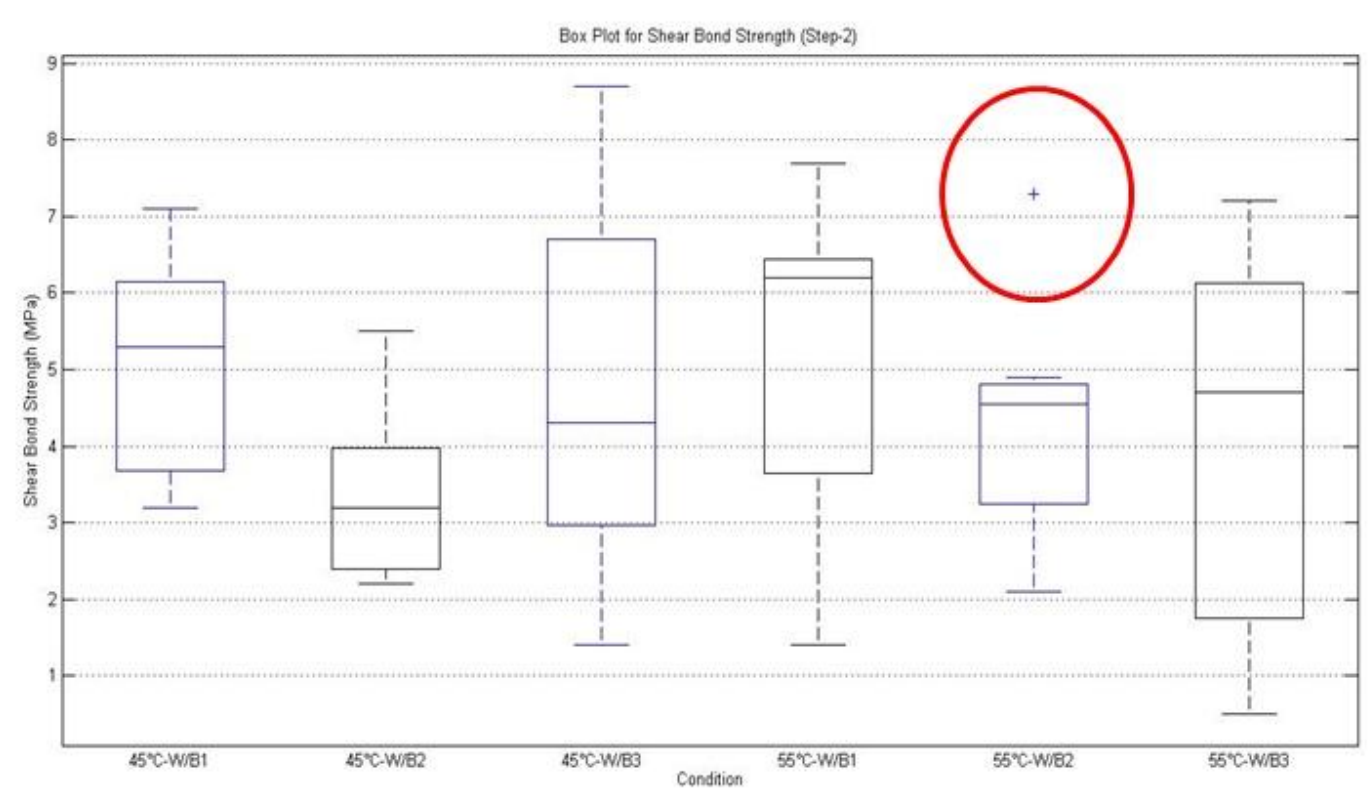

Figure 6.17 Box plot (step-2) 
This plot also contains an outlier. The above step is repeated one more time to check if there is any more outlier. The resulting plot is presented in Figure 6.18. This plot shows no more outlier. The results excluding the outliers are discussed in the next paragraph.

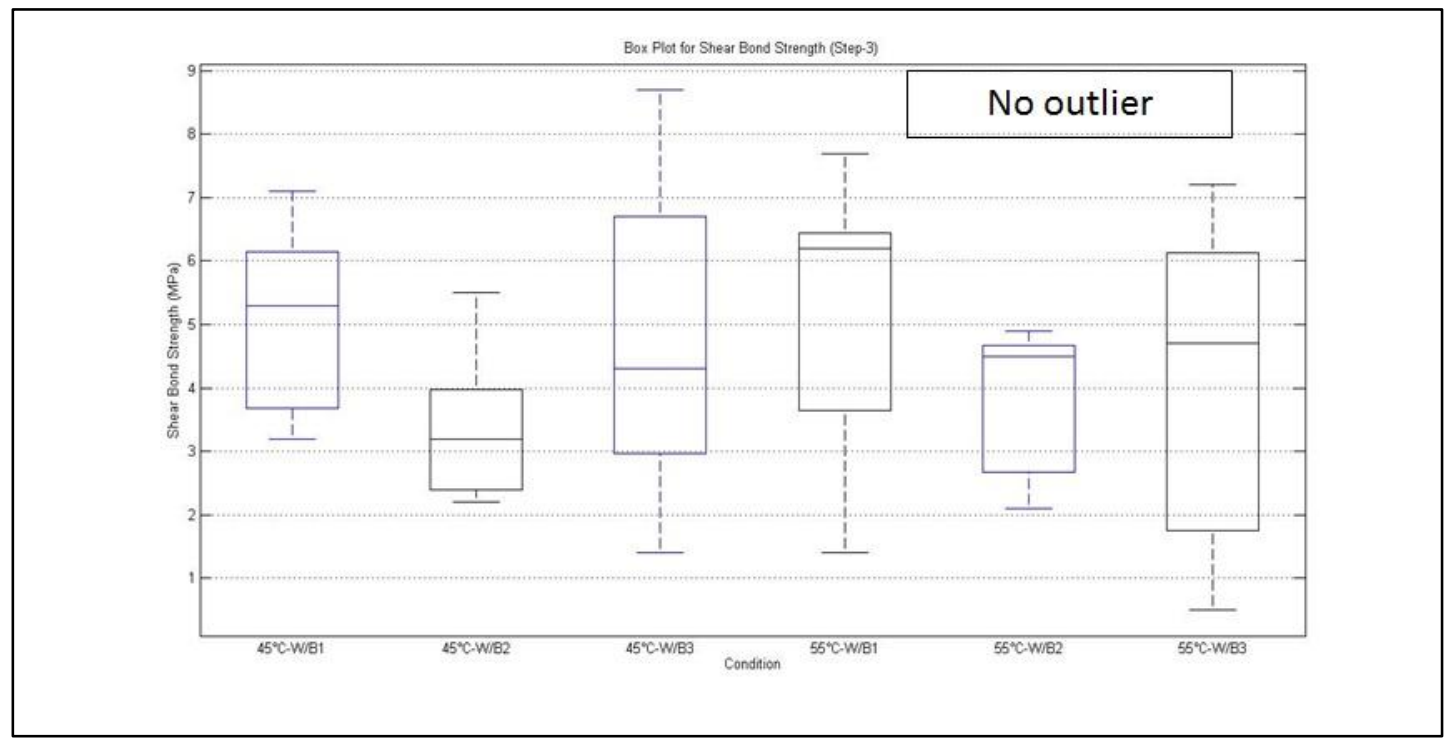

Figure 6.18 Box plot (step-3)

\subsubsection{Results and Discussion}

The average values of the bond strength are reported in Table 6.2.

Table 6.2 Bond strength (by direct shear)

\section{Mix-2 (finer fraction)}

\section{Curing condition}

\section{Surface}

treatment

$$
45^{\circ} \mathrm{C}-\mathrm{W}
$$

$55^{\circ} \mathrm{C}-\mathrm{W}$

\begin{tabular}{cc|cc}
\hline $\begin{array}{c}\text { Bond strength } \\
(\mathrm{MPa})\end{array}$ & COV (\%) & $\begin{array}{c}\text { Bond strength } \\
(\mathrm{MPa})\end{array}$ & COV (\%) \\
& & & \\
\end{tabular}

\begin{tabular}{lcccc}
\hline Mech & $5.0 \pm 0.5$ & 27.57 & $5.0 \pm 0.7$ & 44.27 \\
Mech + Epoxy & $3.3 \pm 0.4$ & 34.55 & $3.9 \pm 0.5$ & 31.82 \\
Mech + Epoxy + & $4.6 \pm 0.8$ & 52.80 & $4.3 \pm 0.8$ & 57.91 \\
Filler & & & \\
\hline
\end{tabular}


Note: $1 \mathrm{MPa}=145 \mathrm{psi}$

The above results are plotted in Figure 6.19 and Figure 6.20 below.

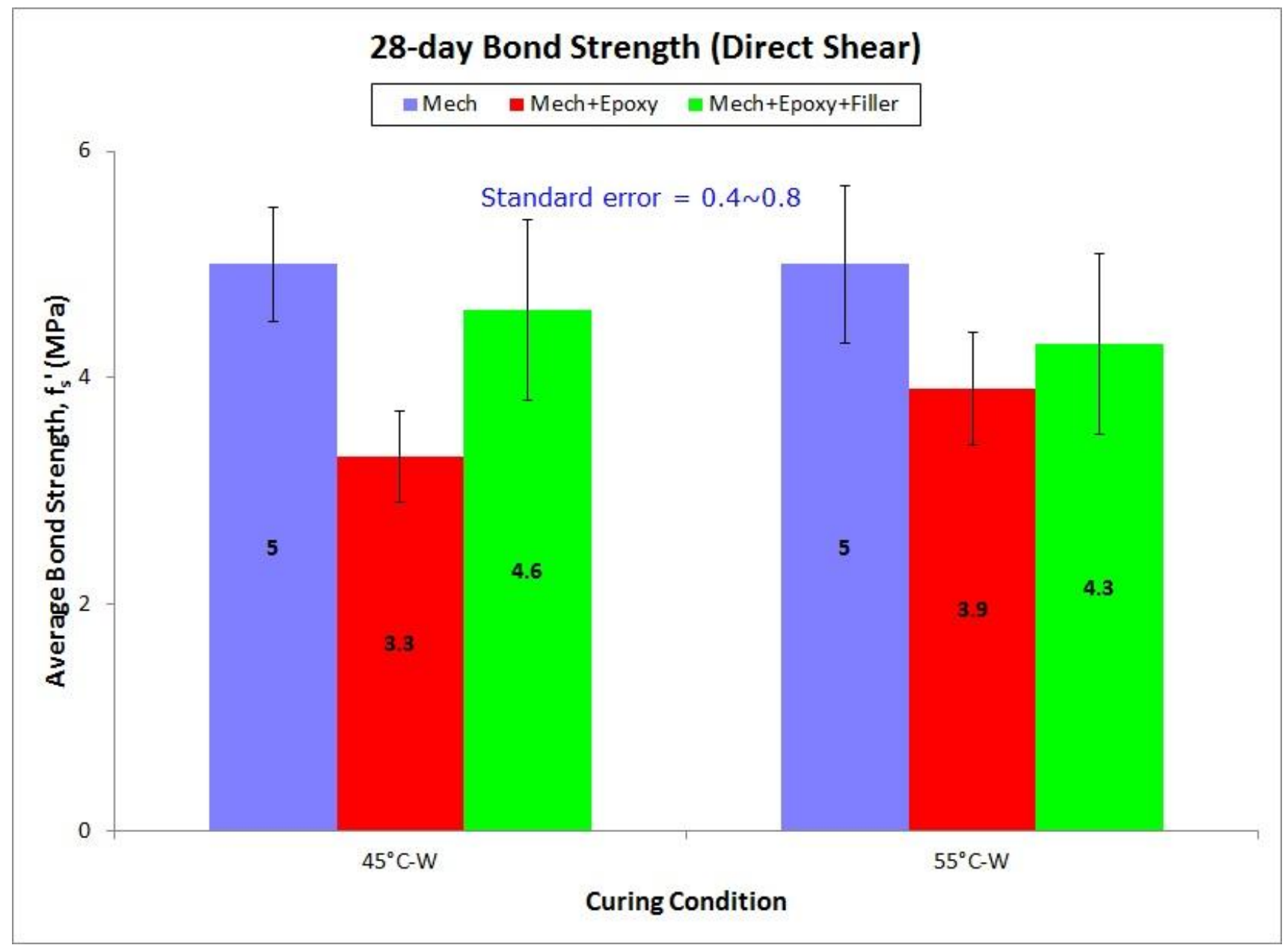

Note: $1 \mathrm{MPa}=145 \mathrm{psi}$

Figure 6.19 Bond strength by direct shear (curing condition-wise) 


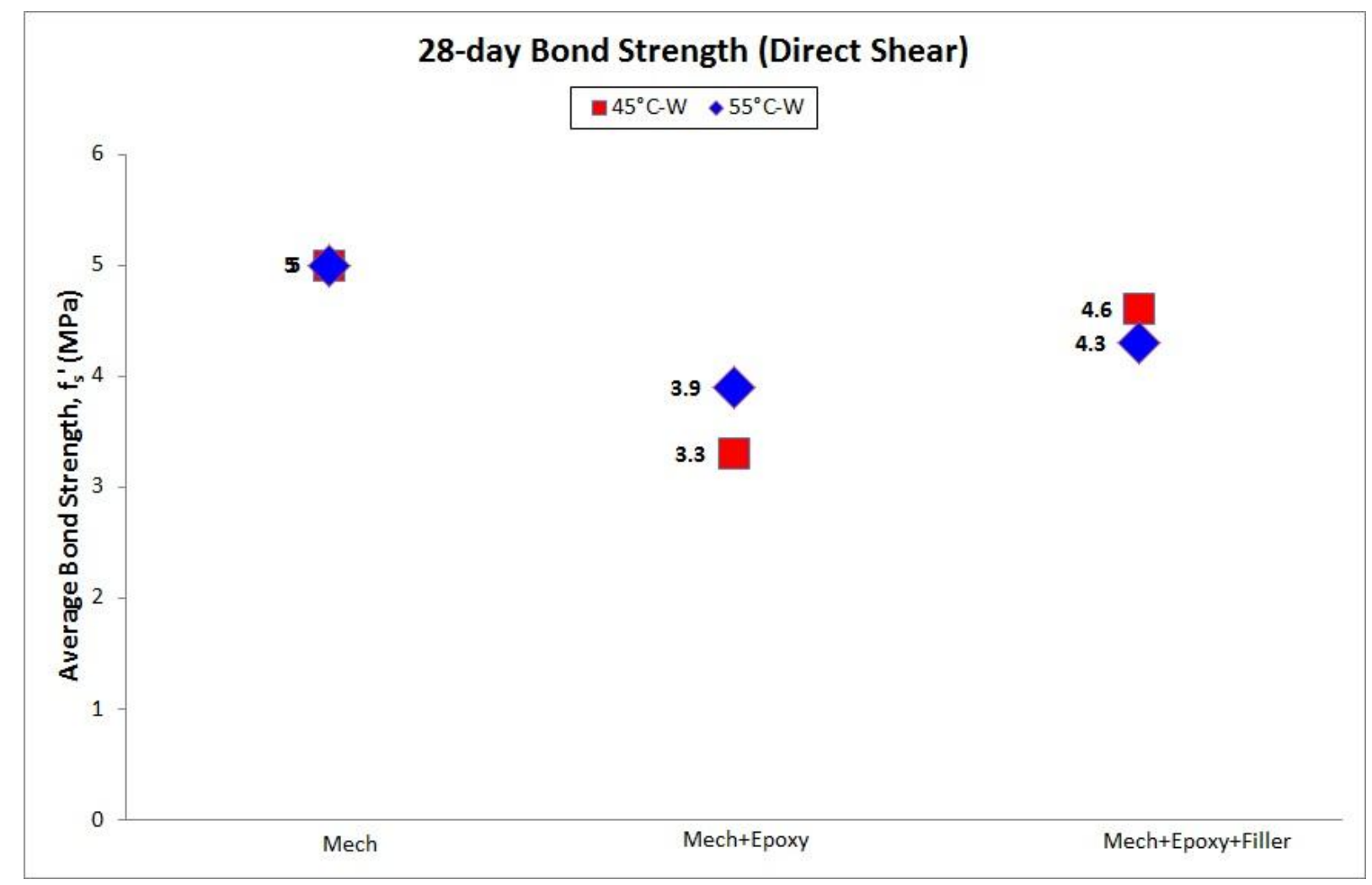

Note: $1 \mathrm{MPa}=145 \mathrm{psi}$

Figure 6.20 Bond strength by direct shear (surface treatment-wise)

Figure 6.19 shows that for ' $45^{\circ} \mathrm{C}-\mathrm{W}^{\prime}$ curing condition, bond strength of specimens with 'Mech' surface treatment is 52\% higher than 'Mech+Epoxy' surface treatment and $9 \%$ higher than 'Mech+Epoxy+Filler' surface treatment. For ' $55^{\circ} \mathrm{C}-\mathrm{W}$ ' curing condition, bond strength of specimens with 'Mech' surface treatment is $28 \%$ and $16 \%$ higher than 'Mech+Epoxy' surface treatment and 'Mech+Epoxy+Filler' surface treatment, respectively. We can infer that very good bonding was achieved through 'Mech' and 'Mech+Epoxy+Filler' surface treatments.

When the same bond strength values are plotted in a different way in Figure 6.20, it shows that for 'Mech' surface treatment, no change in bond strength was observed between two different temperature conditions. For 'Mech+Epoxy' surface treatment, ' $55^{\circ} \mathrm{C}-\mathrm{W}^{\prime}$ curing condition yielded $18 \%$ higher bond strength values than $145^{\circ} \mathrm{C}-\mathrm{W}^{\prime}$ curing condition. For 'Mech+Epoxy+Filler' surface treatment, ${ }^{\prime} 45^{\circ} \mathrm{C}-\mathrm{W}^{\prime}$ curing condition has $7 \%$ higher bond strength than ' $55^{\circ} \mathrm{C}-\mathrm{W}$ ' curing condition. 
The coefficient of variation (COV) values for direct shear test lies between $27 \%$ and $58 \%$. Such high COV values indicate relatively larger scatter in the data.

Table 6.3 compares the maximum value of bond strength obtained in this study with that of FRC developed by (Sun 2004) and (Luo 2002) with similar size of specimens and similar test methods. It shows that bond strength of HPFRC/NC is $138 \%$ higher than that of FRC/NC (Luo 2002) and 10\% lower than that of FRC/NC (Sun 2004).

Table 6.3 Comparison of bond strength values (direct shear)

\section{Bond strength by direct shear (MPa)}

HPFRC

(present study)
FRC

(Sun 2004)
FRC

$\begin{array}{lll}5.0 & 5.5 & 2.1\end{array}$

Note: $1 \mathrm{MPa}=145 \mathrm{psi}$

\subsection{Bond Strength by Slant Shear}

\subsubsection{Summary of Test Method}

This test method determines the bond strength between two equal sections of a 75 $\mathrm{mm}$ by $150 \mathrm{~mm}$ ( $3^{\prime \prime}$ by $6^{\prime \prime}$ ) cylinder made of hardened concrete (NC) and freshly-mixed HPFRC in accordance with ASTM C882 (Standard Test Method for Bond Strength of EpoxyResin Systems Used With Concrete By Slant Shear). The bonding area is at $30^{\circ}$ angle with the vertical. The test was performed by determining the compressive strength of the composite cylinder (schematically shown in Figure 6.21).

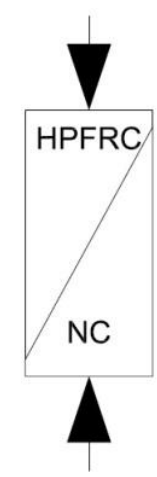

Figure 6.21 Schematic diagram of slant shear test 


\subsubsection{Preparation of Specimens}

The procedure for preparation of the test specimens is outlined below:

a. Dummy sections, as shown in Figure 6.22, were prepared for casting of one half (NC) of each composite cylinder. The dimensions of the dummy section were slightly modified from the dimensions given in ASTM C882, so that it could easily fit into the cylinder mold. Figure 6.23 and Figure 6.24 show the dimensions according to ASTM C882 and the modified dimensions used in the present study, respectively. The dummy sections were cut at the required angle from commercially available solid poly-vinyl chloride (PVC) rod.

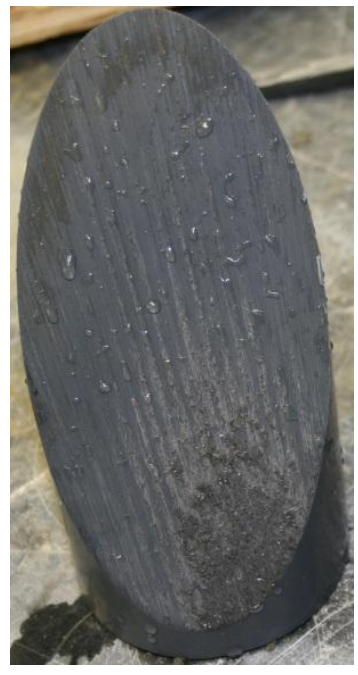

Figure 6.22 Dummy section (typ)

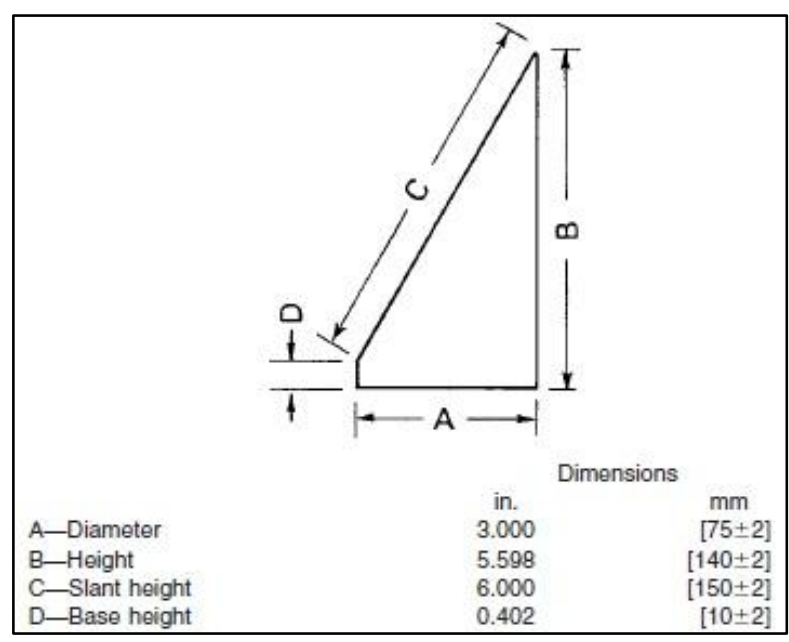

Figure 6.23 Dimensions of dummy section (as per ASTM C882) 


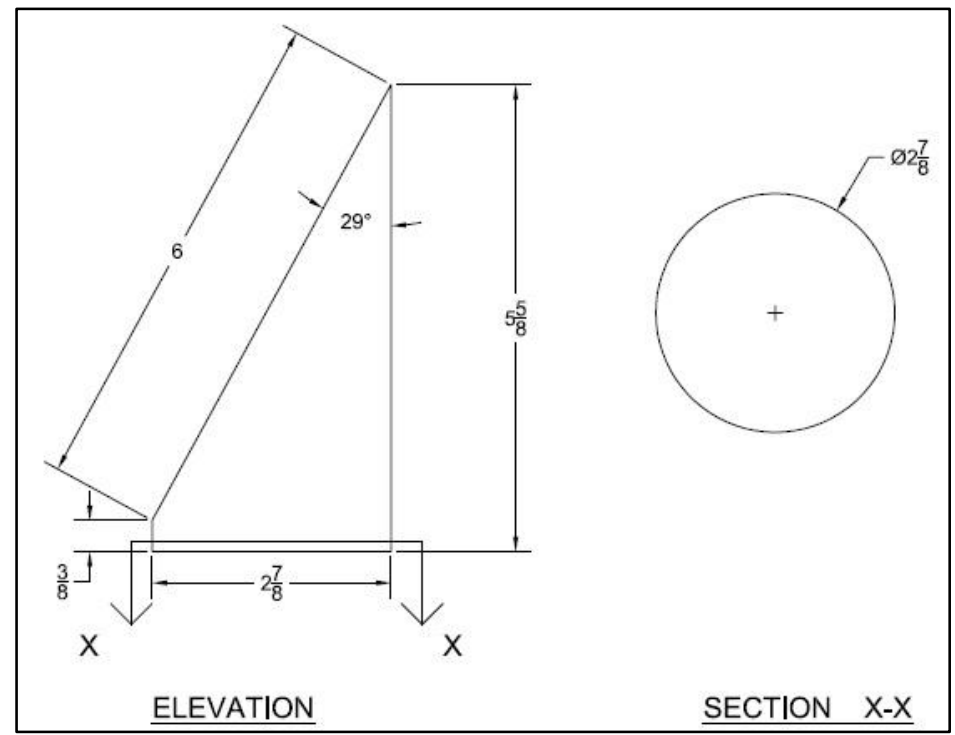

Note: All dimensions are in inch. 1 inch $=25.4 \mathrm{~mm}$

Figure 6.24 Dimensions of dummy section (present study)

b. Water based mold releasing agent, commercially known as RHEOFINISH 211 (manufactured by BASF Construction Chemicals), was applied to the dummy section before placing it inside the plastic cylindrical mold. The dummy section was positioned with the slant side up.

c. NC was poured in the mold in three layers of approximately equal volume. Each layer was compacted with 25 strokes of the tamping rod. The top surface was finished off with a trowel.

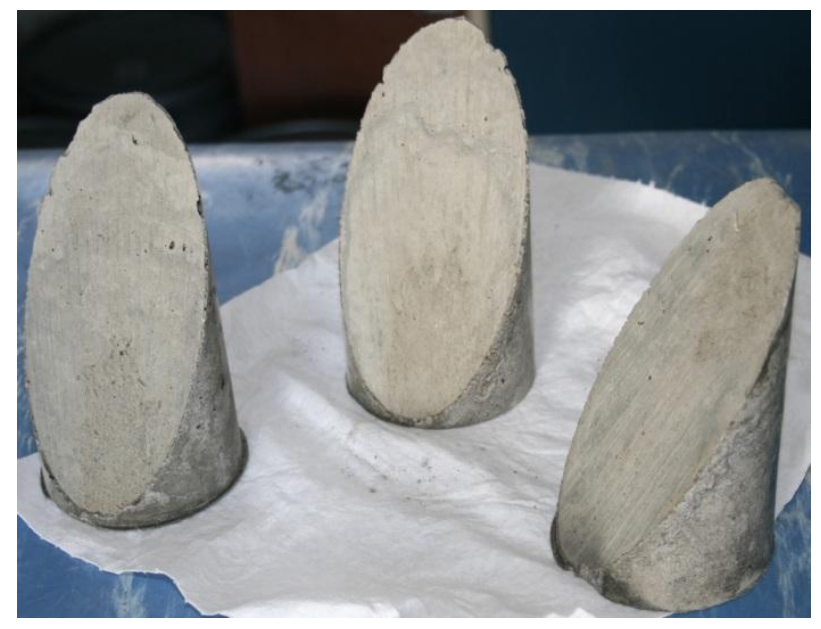

Figure 6.25 Substrate concrete (NC) 
d. Immediately after casting, the top surface of the mold was covered with wet burlap and kept in the moist curing room at $23 \pm 2^{\circ} \mathrm{C}\left(73 \pm 3^{\circ} \mathrm{F}\right)$.

e. 48 hours after casting of NC, the burlap was removed and the slant surface was sandblasted to improve the bond between NC and HPFRC. The surface preparation was done simulating CSP-7 of ICRI 03732 (Technical Guideline No. 03732 by International Concrete Repair Institute). Figure 6.25 and Figure 6.26 show the cast surface and sandblasted surface of substrate, respectively.

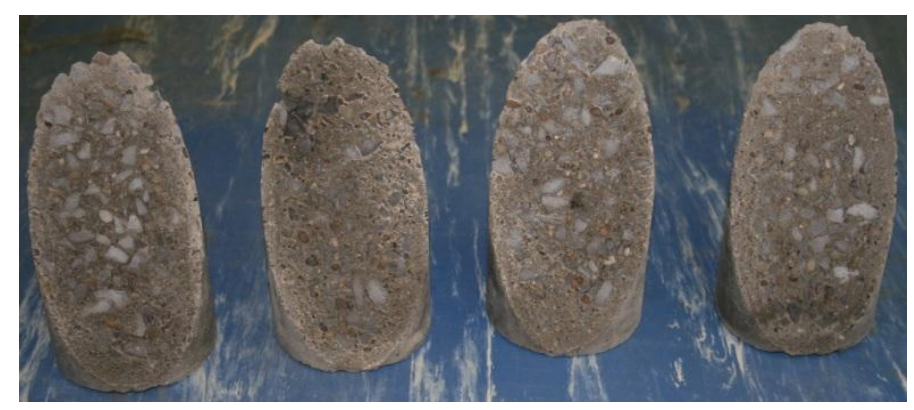

Figure 6.26 Sandblasted substrate surface

f. After sandblasting, the slant surface was thoroughly cleaned with water.

g. Due to equal diameter of the cylinder mold and the bottom of the substrate concrete (NC) in the form of a half-cylinder, the substrate could not be fit into the cylinder mold directly for casting of HPFRC. In order to fit the concrete inside the mold, the mold was cut into two equal halves. The substrate concrete was placed with the slant side up in one half of the mold and the other half was then put on top of it to form a cylinder. Commercially available waterproof duct tape was used to attach the two halves. Figure 6.27 shows the mold ready for HPFRC casting.

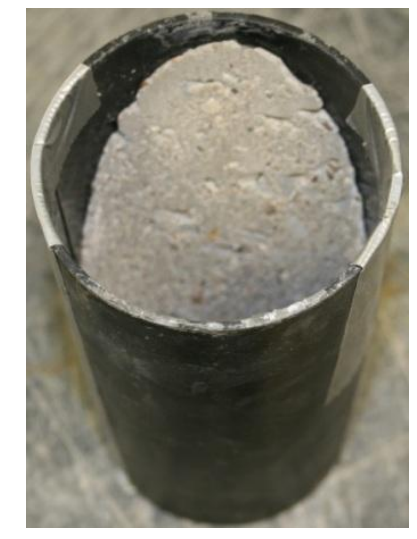

Figure 6.27 Mold ready for repair casting 
h. Slight increase in diameter of the mold due to the above process did not affect the end result since actual area of the bond surface was measured and used to calculate the bond strength.

i. After the mold was ready, the slant surface of the substrate was further treated by one of the following methods before the repair concrete (HPFRC) was poured:

- Surface preparation - B1 (Mech): the sandblasted surface (prepared in step e above) was cleaned and made ready for casting of overlay.

- Surface preparation - B2 (Mech+Epoxy): a two component epoxy-based bonding agent (commercial name - Epoxy.com Product \# 7) was applied to the sandblasted substrate at the rate of $60 \mathrm{sq}$. $\mathrm{ft} .\left(6 \mathrm{~m}^{2}\right)$ per gallon. The repair material was then poured while the bonding agent was still tacky.

- Surface preparation - B3 (Mech+Epoxy+Filler): SCS 90 was added to the two component epoxy-based bonding agent described above (15\% by wt. of bonding agent) and the slurry was applied to the sandblasted surface before pouring of HPFRC. HPFRC was poured while the bonding agent was still tacky.

j. Immediately after casting of the repair, the exposed surface of each mold was covered with plastic sheet to prevent loss of moisture. Then the specimens were kept in the moist curing room at $23 \pm 2^{\circ} \mathrm{C}\left(73 \pm 3^{\circ} \mathrm{F}\right)$ for 24 hours.

k. 24 hours after casting of HPFRC, the specimens were demolded and cured in the curing tank as per the curing conditions mentioned in the test matrix in Table 6.4 .

I. The specimens were cured in water for 24 days after the casting of HPFRC and then kept in air in the moist curing room until the day of testing. This was done in order to make the interface (specially the epoxy treated interface) dry before testing. Figure 6.28 shows the composite cylinder ready for testing.

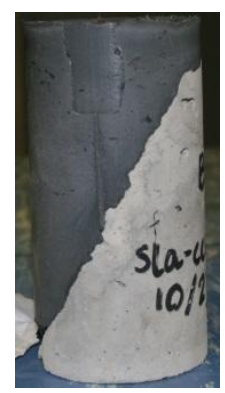

Figure 6.28 Composite cylinder 
Table 6.4 presents the test matrix for slant shear test.

Table 6.4 Test matrix for slant shear test

No. of Specimens

\begin{tabular}{cccc}
$\begin{array}{c}\text { Curing } \\
\text { Conditions }\end{array}$ & $\begin{array}{c}\text { Surface condition-1 } \\
\text { (Mech) }\end{array}$ & $\begin{array}{c}\text { Surface condition-2 } \\
\text { (Mech+Epoxy) }\end{array}$ & $\begin{array}{c}\text { Surface condition-3 } \\
\text { (Mech+Epoxy+Filler) }\end{array}$ \\
\hline $45^{\circ} \mathrm{C}-\mathrm{W}$ & 8 & 8 & 8 \\
$55^{\circ} \mathrm{C}-\mathrm{W}$ & 8 & 8 & 8 \\
\hline
\end{tabular}

\subsubsection{Testing}

The composite cylinders were tested in compression in accordance with ASTM C39. The bond strength is calculated as per the formula shown below:

Bond strength $=($ Load at failure $) /(n a b)$

$a, b$ are the semi-major and semi-minor axes of the elliptical bond surface, respectively.

Some representative failure surfaces are shown in Figure 6.29 and Figure 6.30.

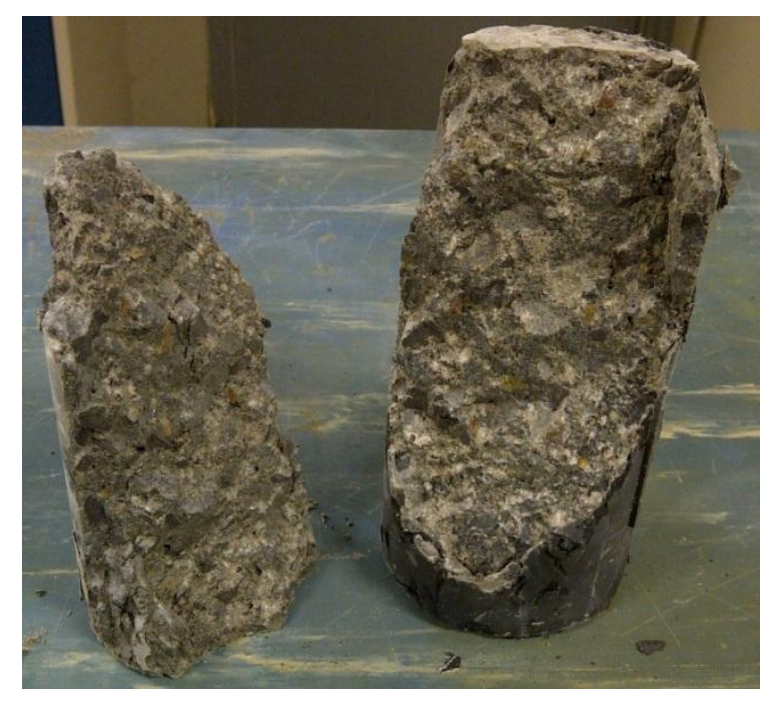

Figure 6.29 Failure through substrate 


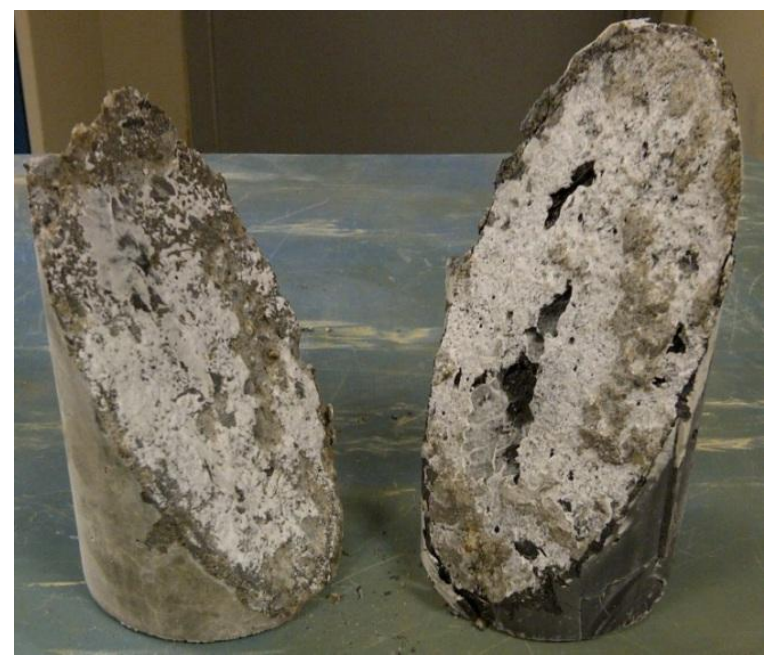

Figure 6.30 Failure through interface

\subsubsection{Results and Discussion}

For each combination shown in Table 6.4, 3 specimens were tested after 14 days of casting of HPFRC and 5 specimens were tested after 28 days of casting of HPFRC. The results including failure mode of each specimen are presented in Appendix C. The average values of bond strength are reported in Table 6.5 and Table 6.6.

Table 6.5 Bond strength by slant shear (14-day)

\section{Mix-2 (finer fraction)}

\begin{tabular}{|c|c|c|c|c|}
\hline \multirow{3}{*}{$\begin{array}{c}\text { Surface } \\
\text { treatment }\end{array}$} & \multicolumn{4}{|c|}{ Curing condition } \\
\hline & \multicolumn{2}{|c|}{$45^{\circ} \mathrm{C}-\mathrm{W}$} & \multicolumn{2}{|c|}{$55^{\circ} \mathrm{C}-\mathrm{W}$} \\
\hline & $\begin{array}{c}\text { Bond strength } \\
\text { (MPa) }\end{array}$ & $\operatorname{cov}(\%)$ & $\begin{array}{c}\text { Bond strength } \\
\text { (MPa) }\end{array}$ & $\operatorname{COV}(\%)$ \\
\hline Mech & $17.1 \pm 1.3$ & 12.94 & $18.5 \pm 2.0$ & 18.96 \\
\hline Mech + Epoxy & $13.0 \pm 1.6$ & 21.35 & $13.4 \pm 1.2$ & 15.47 \\
\hline $\begin{array}{l}\text { Mech + Epoxy + } \\
\text { Filler }\end{array}$ & $13.1 \pm 0.3$ & 3.41 & $15.3 \pm 0.8$ & 9.01 \\
\hline
\end{tabular}

Note: $1 \mathrm{MPa}=145 \mathrm{psi}$ 
Table 6.6 Bond strength by slant shear (28-day)

Mix-2 (finer fraction)

\begin{tabular}{|c|c|c|c|c|}
\hline \multirow{3}{*}{$\begin{array}{c}\text { Surface } \\
\text { treatment }\end{array}$} & \multicolumn{4}{|c|}{ Curing condition } \\
\hline & \multicolumn{2}{|c|}{$45^{\circ} \mathrm{C}-\mathrm{W}$} & \multicolumn{2}{|c|}{$55^{\circ} \mathrm{C}-\mathrm{W}$} \\
\hline & $\begin{array}{c}\text { Bond strength } \\
\text { (MPa) }\end{array}$ & $\operatorname{cov}(\%)$ & $\begin{array}{c}\text { Bond strength } \\
\text { (MPa) }\end{array}$ & $\operatorname{cov}(\%)$ \\
\hline Mech & $20.1 \pm 0.5$ & 5.22 & $21.2 \pm 1.1$ & 10.44 \\
\hline Mech + Epoxy & $14.8 \pm 0.6$ & 9.79 & $15.9 \pm 0.6$ & 7.44 \\
\hline $\begin{array}{l}\text { Mech + Epoxy + } \\
\text { Binder }\end{array}$ & $14.3 \pm 1.2$ & 18.89 & $16.2 \pm 0.4$ & 5.16 \\
\hline
\end{tabular}

Note: $1 \mathrm{MPa}=145 \mathrm{psi}$

The above results are plotted in Figure 6.31 and Figure 6.32 below.

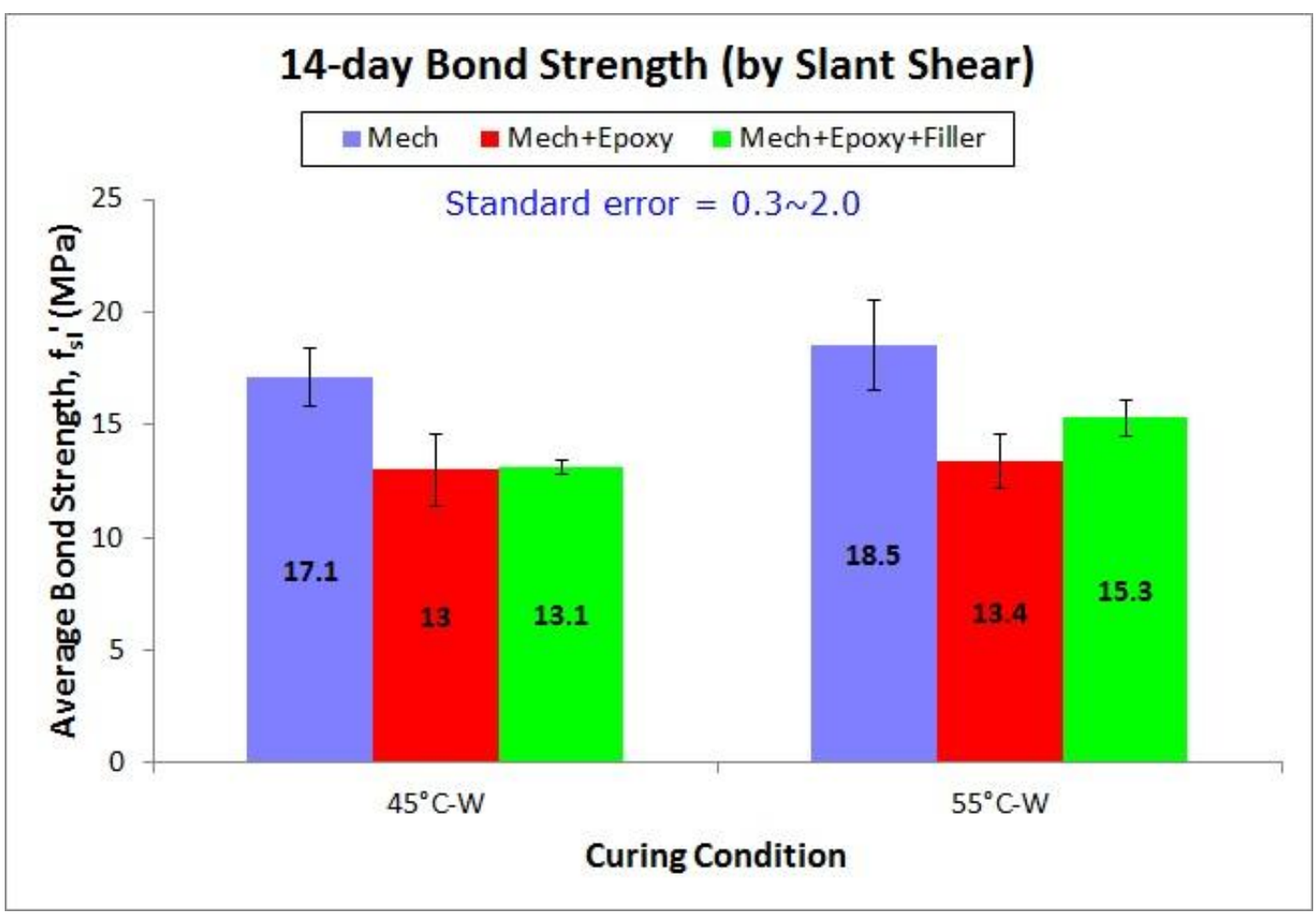

Figure 6.31 14-day bond strength by slant shear (curing condition-wise) 


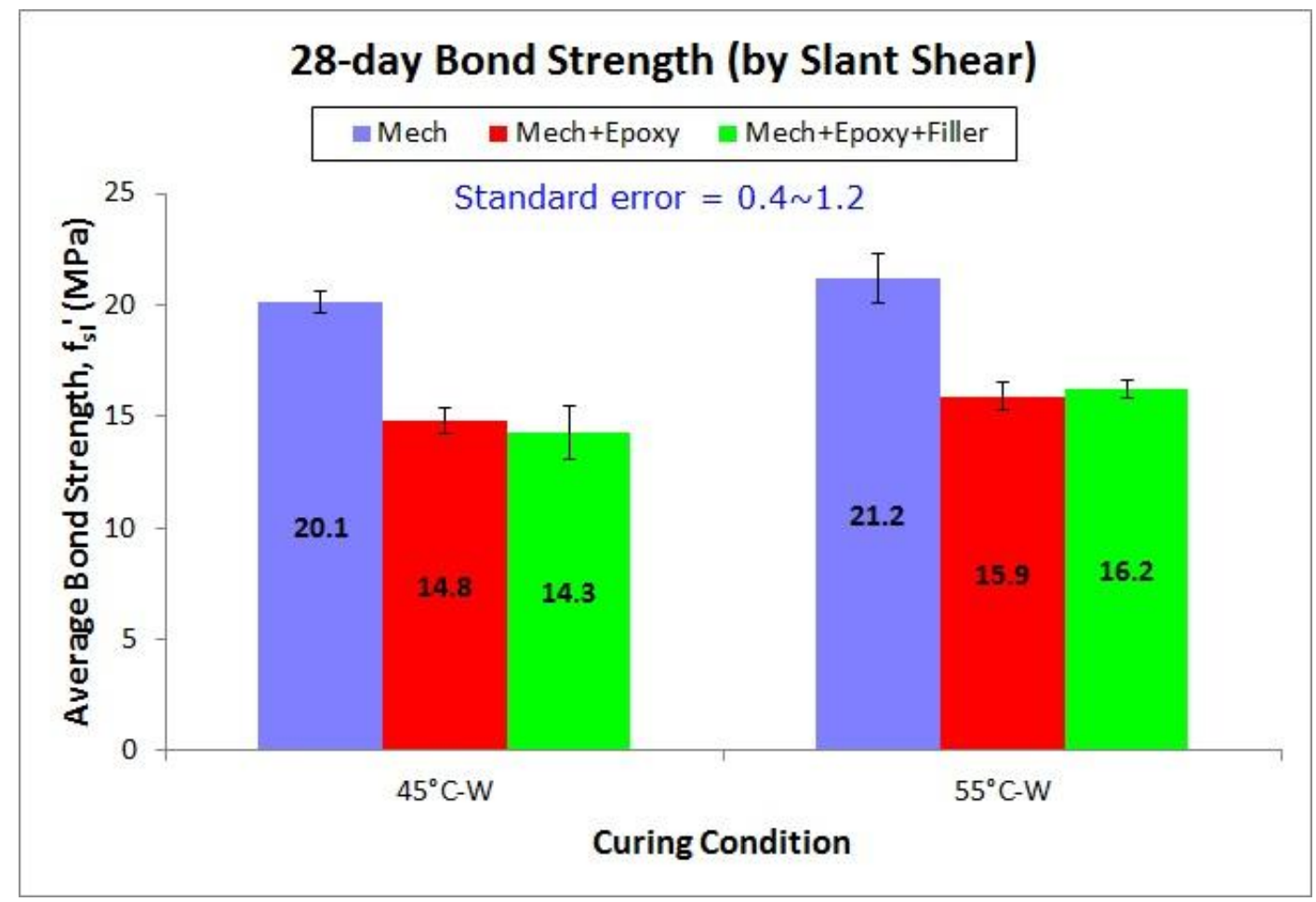

Figure 6.32 28-day bond strength by slant shear (curing condition-wise)

Both Figure 6.31 and Figure 6.32 show that for a particular curing condition, bond strength is the maximum for specimens with only sandblasted surface (Mech). It implies that better bonding was achieved by only mechanical means. There is no significant difference (range: 0.8 to 3.5\%) in bond strength values between the other two surface preparations with one exception: 14-day bond strength value of combination $55^{\circ} \mathrm{C}$ $\mathrm{W} /$ Mech+Epoxy+Filler is $14 \%$ higher than $55^{\circ} \mathrm{C}-\mathrm{W} /$ Mech+Epoxy. Overall there has been increase in bond strength (5.9 to $18.7 \%$ ) from 14 -day results to 28 -day results.

When the same bond strength values are plotted in a different way in Figure 6.33 and Figure 6.34, they show that for a particular surface treatment, bond strength of specimens cured at higher temperature are marginally higher (3.1 to $16.8 \%$ ) than that cured by lower temperature. 


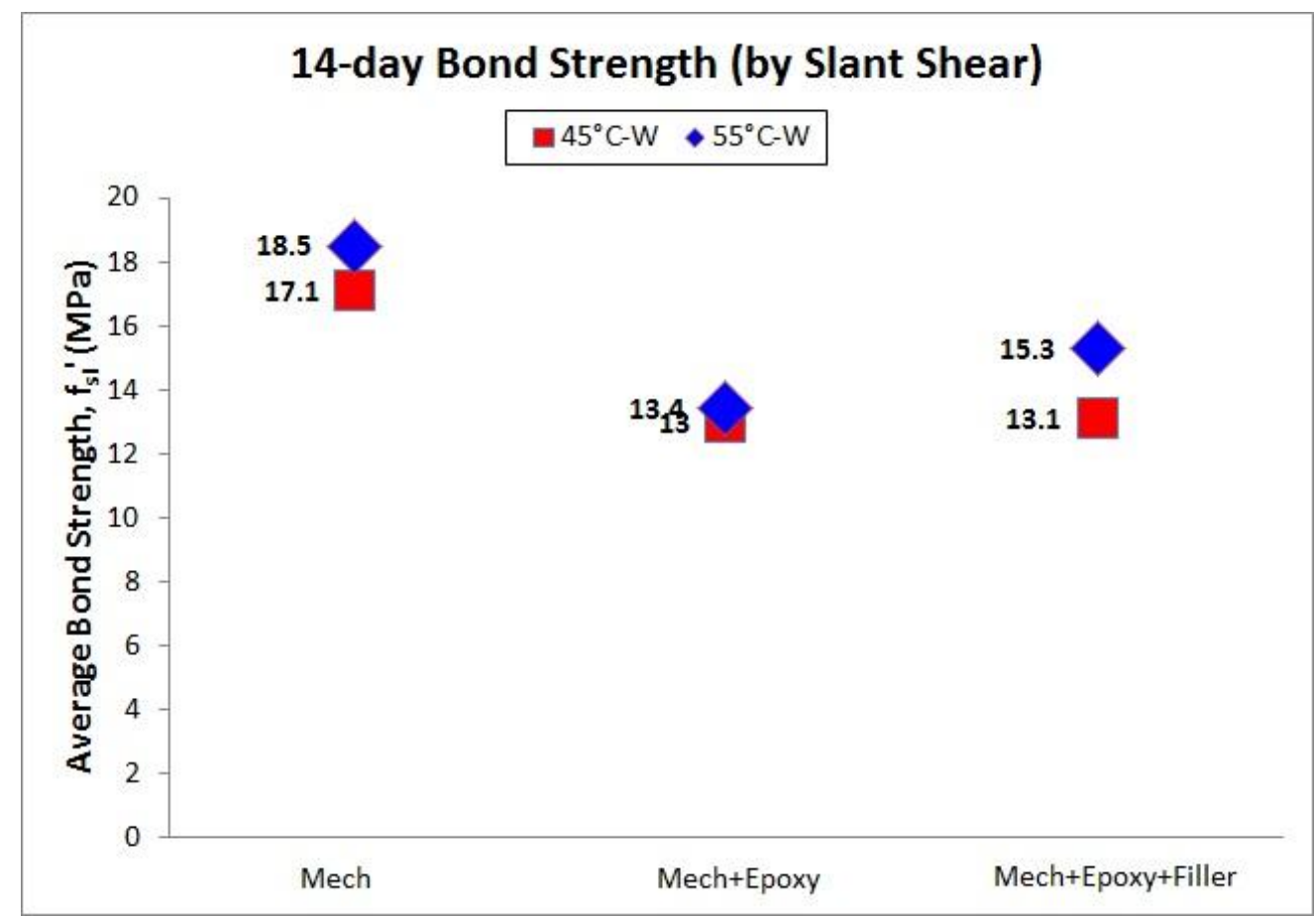

Note: $1 \mathrm{MPa}=145 \mathrm{psi}$

Figure 6.33 14-day bond strength by slant shear (surface treatment-wise)

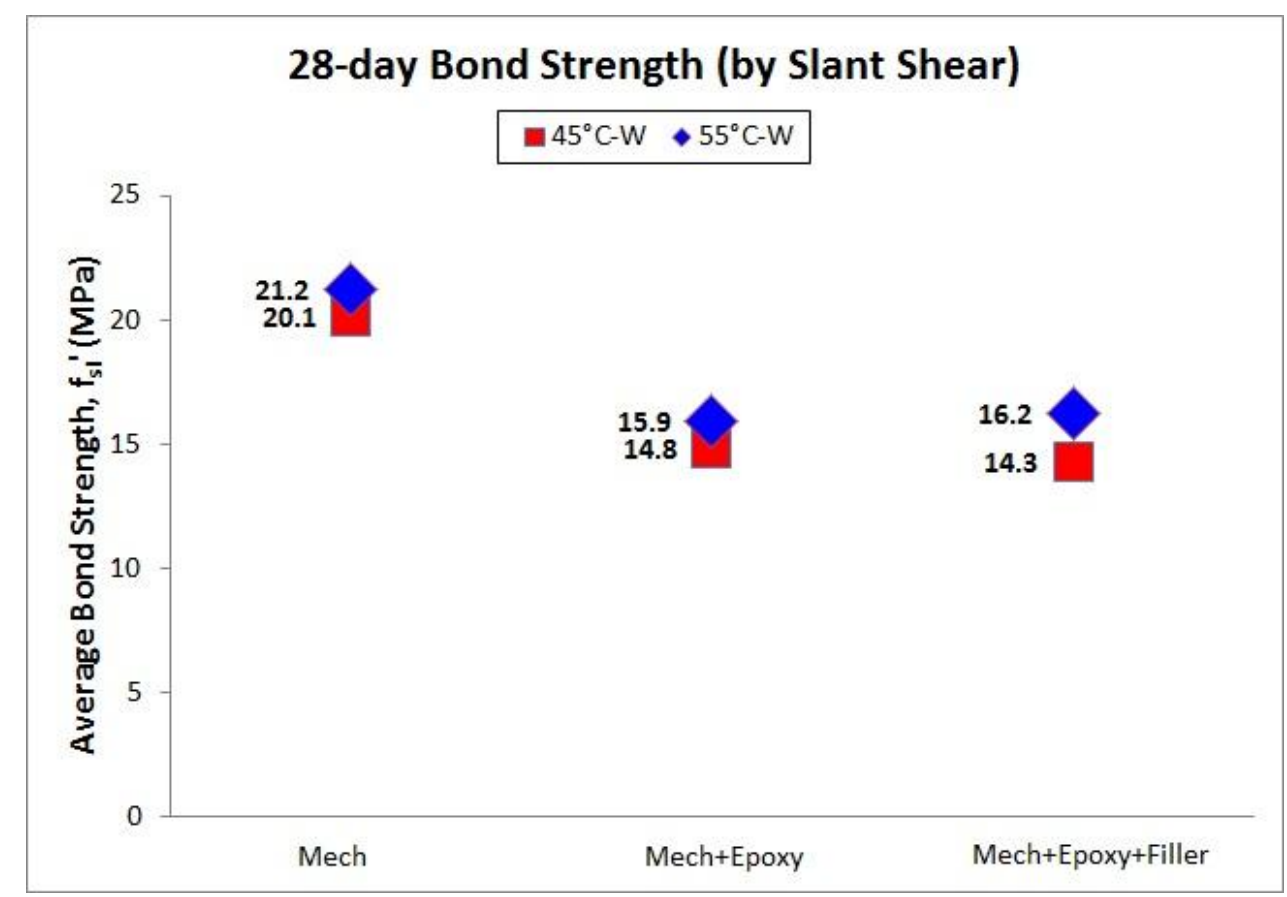

Note: $1 \mathrm{MPa}=145 \mathrm{psi}$

Figure 6.34 28-day bond strength by slant shear (surface treatment-wise) 
The average coefficient of variation (COV) of all the 28-day test results is less than $10 \%$. It indicates that the results are fairly consistent throughout the test.

Table 6.7 compares the maximum value of bond strength by slant shear obtained in this study with that of UHPC developed by (Sarkar 2010) and HPC developed by (Konduru 2008). It shows that bond strength of HPFRC is $22 \%$ higher than that of UHPC (Sarkar 2010) and more than $500 \%$ higher than that of HPC (Konduru 2008).

Table 6.7 Comparison of bond strength values (slant shear)

Bond strength by slant shear (MPa)

\begin{tabular}{ccc}
\hline HPFRC & UHPC & HPC \\
(present study) & (Sarkar 2010) & (Konduru 2008) \\
\hline 21.2 & 17.4 & 3.2 \\
\hline Note: $1 \mathrm{MPa}=145 \mathrm{psi}$ & & \\
\hline
\end{tabular}

Note: $1 \mathrm{MPa}=145 \mathrm{psi}$

\subsection{Bond Strength by Pull-Off}

\subsubsection{Summary of Test Method}

This test method determines the bond strength of a repair material to the substrate. The test was carried out in accordance with ASTM C1583 (Standard Test Method for Tensile Strength of Concrete Surfaces and the Bond Strength or Tensile Strength of Concrete Repair and Overlay Materials by Direct Tension [Pull-off Method]). It was performed on the surface of HPFRC (repair material) after the material had been applied to the prepared concrete surface (NC). The test specimen was formed by drilling a core to at least $10 \mathrm{~mm}$ (0.5 in.) below the HPFRC-NC interface and perpendicular to the surface, and leaving the intact core attached to the concrete. A steel disk was bonded to the top surface of the test specimen. A tensile load was applied to the steel disk until failure occurred. The failure load and the failure mode were recorded and the nominal tensile stress at failure was calculated.

Figure 6.35 shows the schematic diagram of pull-off test. 


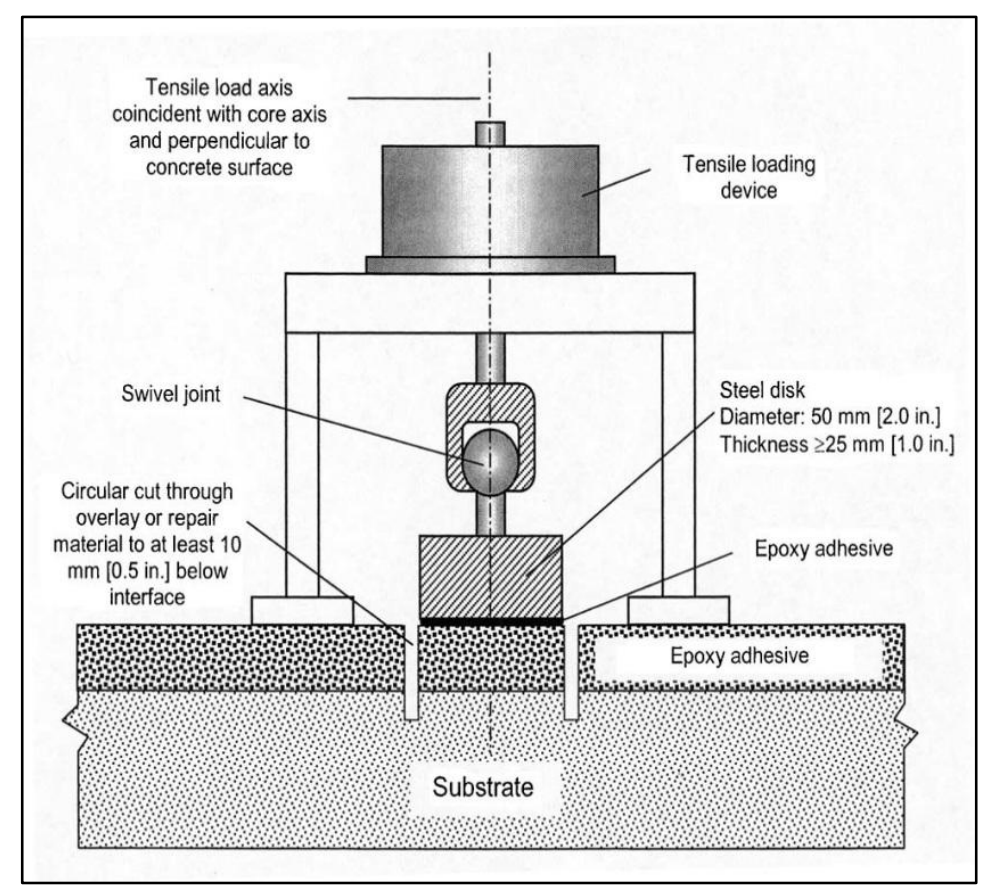

Figure 6.35 Schematic diagram of pull-off test (from ASTM 1583)

There are four possible modes of failure associated with this test. They are a) failure in substrate, b) bond failure at substrate/repair interface, c) failure in repair material, and d) bond failure at repair/epoxy interface. The failure modes are shown in Figure 6.36.

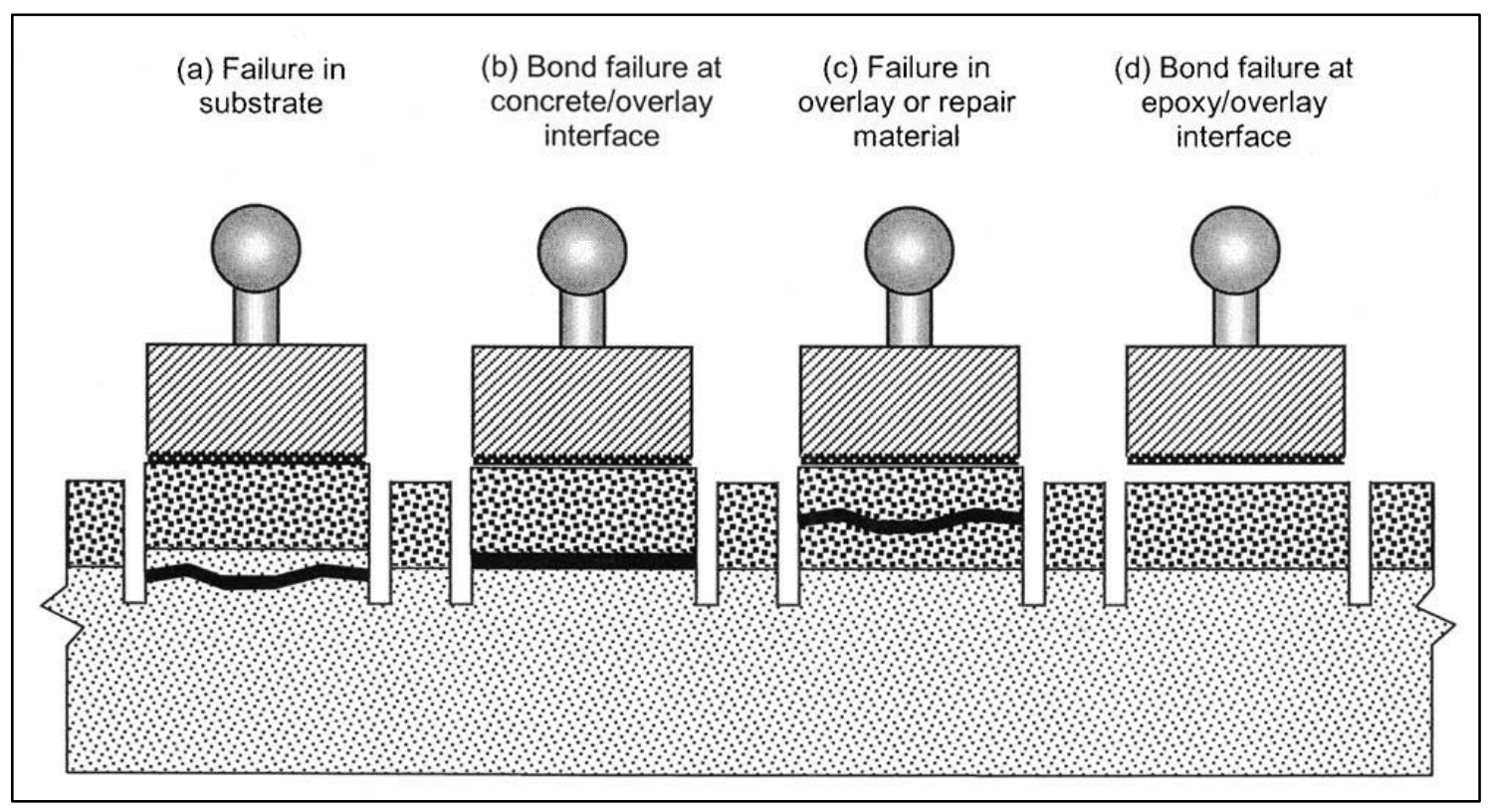

Figure 6.36 Different types of failure modes in pull-off test (from ASTM 1583) 


\subsubsection{Casting of Repair Material}

The procedure for casting the repair material is outlined below:

a. The substrate used in this test was concrete beam of dimension $152 \mathrm{~mm} \times 152$ $\mathrm{mm} \times 910 \mathrm{~mm}\left(6^{\prime \prime} \times 6^{\prime \prime} \times 3^{\prime}\right)$. Four such beams were used in the present study. The beams were cast by (Imani 2010) as part of her study, but were never tested.

b. The surface of the substrate was mechanically roughened with the help of a bush tool (Figure 6.38) in order to improve the bond between NC and HPFRC (as shown in Figure 6.37). The surface preparation was done simulating CSP-7 of ICRI 03732 (Technical Guideline No. 03732 by International Concrete Repair Institute).

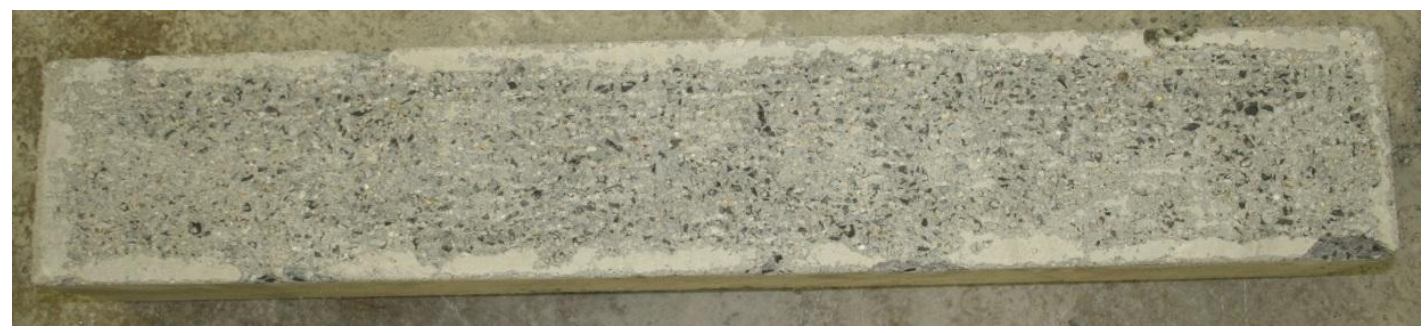

Figure 6.37 Mechanically roughened substrate surface

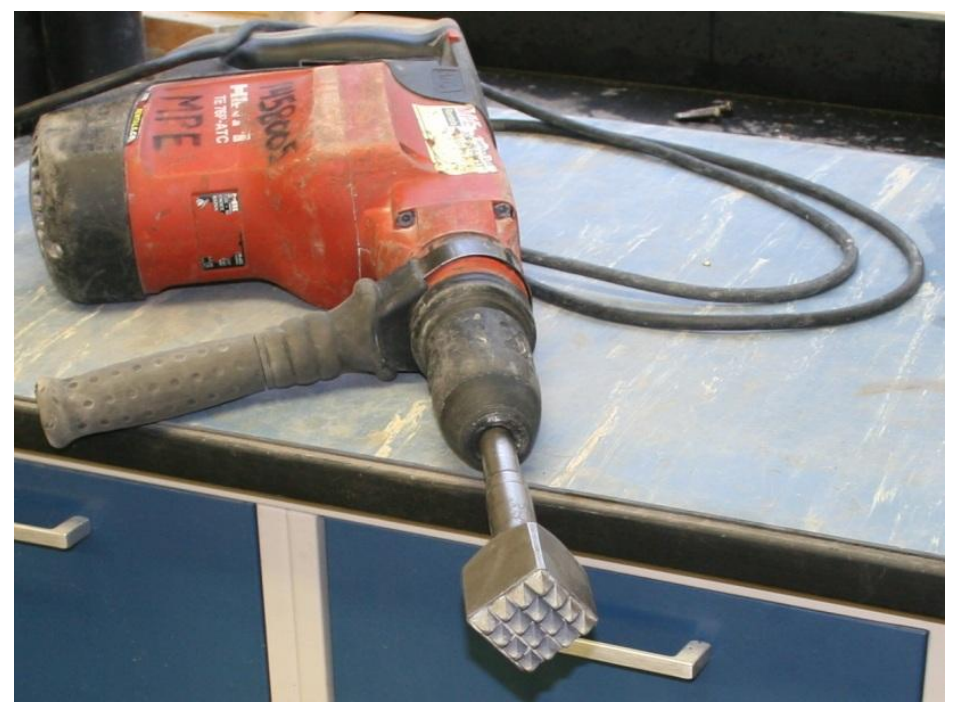

Figure 6.38 Bush tool

c. After roughening, the bond surface was thoroughly cleaned with water and made dry. 
d. Once the surface was dry, a plywood formwork was made to facilitate pouring of repair material. The formwork is shown in Figure 6.39.

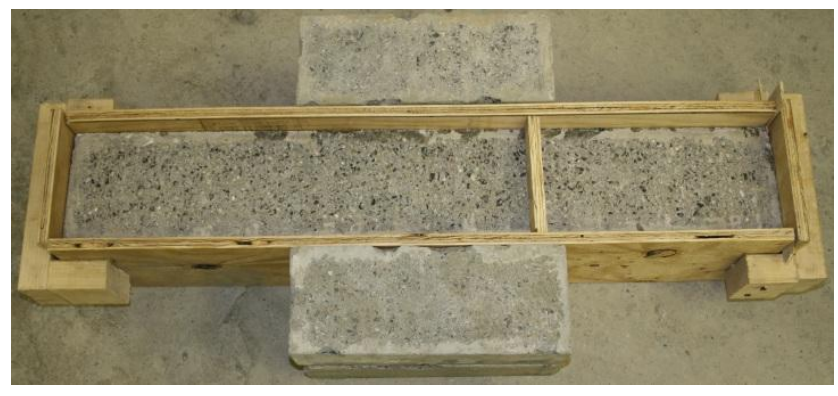

Figure 6.39 Formwork for pouring of repair material

e. After the formwork was ready, the surface of the substrate was further treated by one of the following methods before HPFRC was poured:

- Surface preparation - B1 (Mech): the roughened surface (prepared in step $b$ above) was cleaned and made ready for casting of HPFRC.

- Surface preparation - B2 (Mech+Epoxy): a two component epoxy-based bonding agent (commercial name - Epoxy.com Product \# 7) was applied to the roughened substrate at the rate of $60 \mathrm{sq}$. ft. $\left(6 \mathrm{~m}^{2}\right)$ per gallon. The repair material was then poured while the bonding agent was still tacky.

- Surface preparation - B3 (Mech+Epoxy+Filler): SCS 90 was added to the two component epoxy-based bonding agent described above (15\% by wt. of bonding agent) and the slurry was applied to the roughened surface before pouring of HPFRC. HPFRC was poured while the bonding agent was still tacky. Figure 6.40 shows the finished surface of repair material.

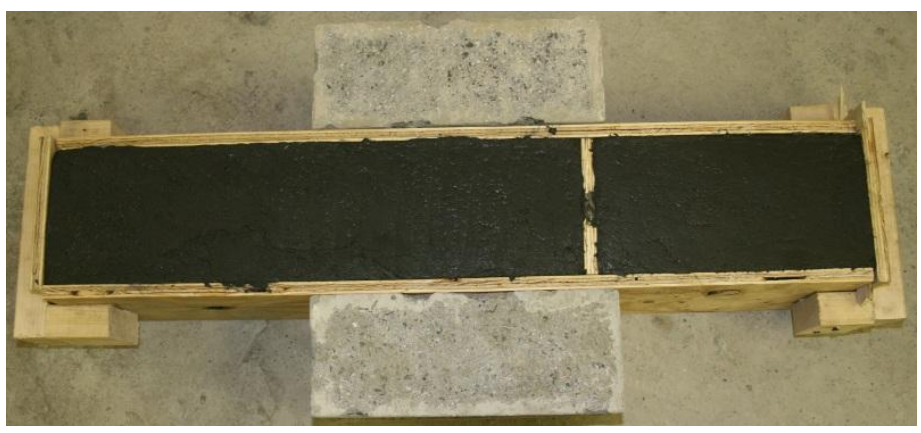

Figure 6.40 Finished surface of repair material (HPFRC)

f. Immediately after casting of the repair material, the top surface of each beam was covered with plastic sheet to prevent loss of moisture (Figure 6.41). Then 
the beams were kept in the moist curing room at $23 \pm 2^{\circ} \mathrm{C}\left(73 \pm 3^{\circ} \mathrm{F}\right)$ for 24 hours.

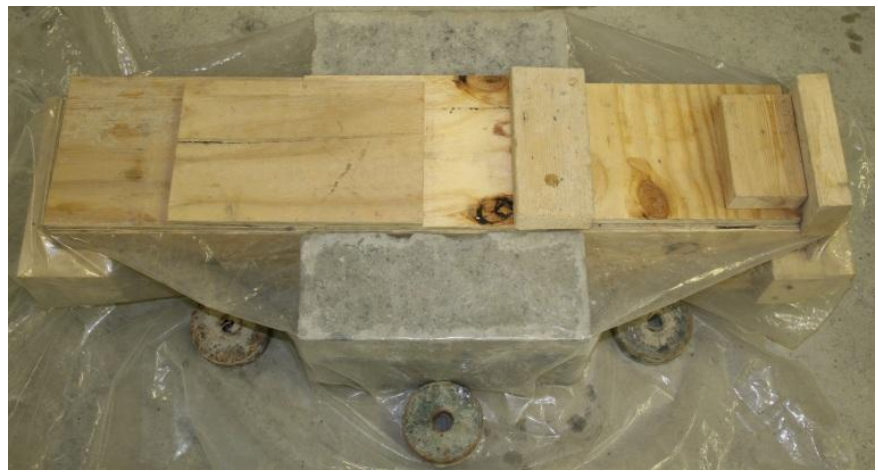

Figure 6.41 Specimen covered with plastic sheet

g. 24 hours after casting of overlay, the formwork was removed and the beams were immersed in the curing tanks as per the curing conditions mentioned in the test matrix (Table 6.8). Picture of the bi-layer specimen in shown in Figure 6.42.

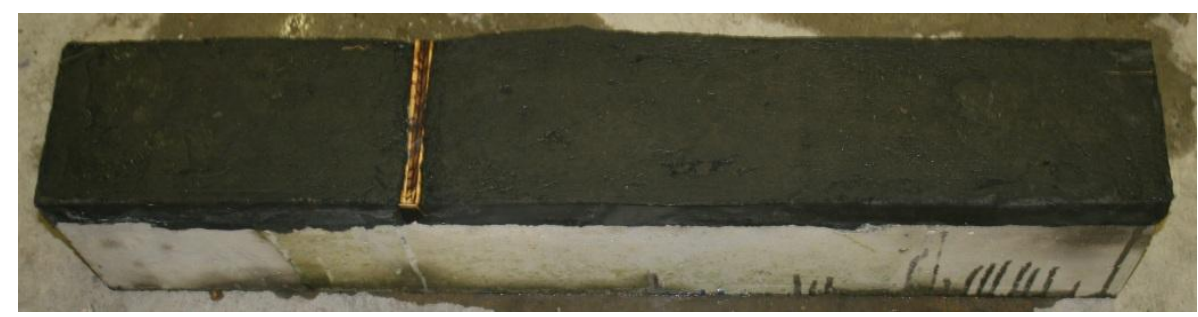

Figure 6.42 Bi-layer specimen

h. The specimens were cured in water for 24 days after the casting of overlay and made ready for core drilling.

Table 6.8 Test matrix for pull-off test

No. of Specimens

\begin{tabular}{cccc}
$\begin{array}{c}\text { Curing } \\
\text { Conditions }\end{array}$ & $\begin{array}{c}\text { Surface condition-1 } \\
\text { (Mech) }\end{array}$ & $\begin{array}{c}\text { Surface condition-2 } \\
\text { (Mech+Epoxy) }\end{array}$ & $\begin{array}{c}\text { Surface condition-3 } \\
\text { (Mech+Epoxy+Filler) }\end{array}$ \\
\hline $45^{\circ} \mathrm{C}-\mathrm{W}$ & 6 & 6 & 6 \\
$55^{\circ} \mathrm{C}-\mathrm{W}$ & 6 & 6 & 6 \\
\hline
\end{tabular}




\subsubsection{Preparation of Test Specimens}

The procedure for preparation of the test specimens is outlined below:

a. After the beams were withdrawn from curing, circular cuts perpendicular to the surface were drilled in each beam with the help of core-cutting equipment (Figure 6.44). Each core was drilled to $15 \mathrm{~mm}$ ( $5 / 8$ in.) below the concrete-overlay interface. The center-to-center distance of adjacent cores was kept $100 \mathrm{~mm}$ (4 in.). The distance from the center of a core to a free edge of the beam was kept $50 \mathrm{~mm}$ ( 2 in.). The test specimens were left intact, attached to the substrate (as shown in Figure 6.43).

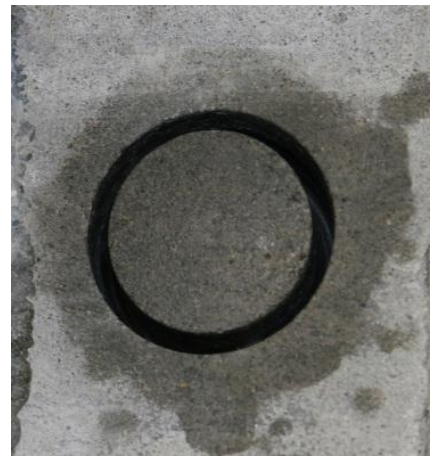

Figure 6.43 Test specimen

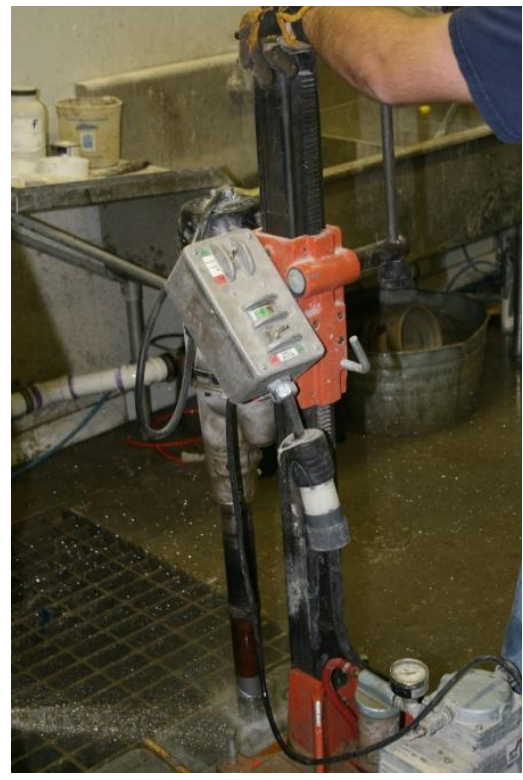

Figure 6.44 Core-cutter 
b. After all the cores were drilled in a beam, the surface was cleaned thoroughly with water and allowed to dry for 48 hours.

c. 2 days after drilling the cores, a $50 \mathrm{~mm}$ ( 2 in.) diameter steel disk was attached to the top of each test specimen using epoxy adhesive. A two component epoxy saturant (MBRACE SATURANT manufactured by BASF) was used for this purpose. Effort was made to ensure that the disk was centered with the test specimen and that the axis of the disk was parallel to the axis of the test specimen.

d. The epoxy adhesive was cured in air for 48 hours before testing.

\subsubsection{Testing}

A tensile loading device, Dyna Z Pull-Off Tester with Digital Manometer (Figure 6.45) having $10 \mathrm{MPa}$ (1450 psi) capacity (manufactured by Proceq SA), was attached to the steel disk. Tensile load was applied at a constant rate of $35 \pm 15 \mathrm{kPa} / \mathrm{s}$ ( $5 \pm 2 \mathrm{psi} / \mathrm{s}$ ) and the failure load and the failure mode were duly recorded. The bond strength is calculated as per the following formula:

Bond strength $=($ Tensile load at failure $) /($ Area $)$

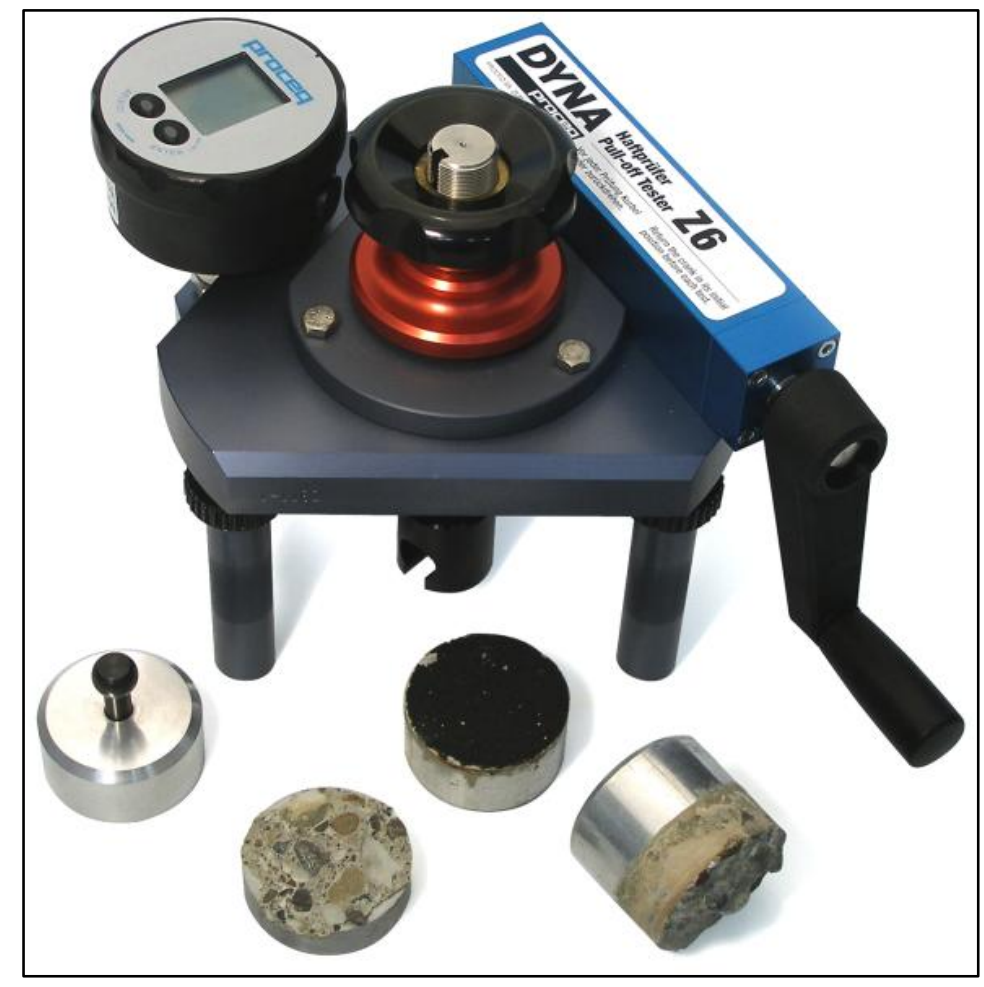

Figure 6.45 Pull-off tester

Some representative failure surfaces are shown in Figure 6.46 and Figure 6.47. 


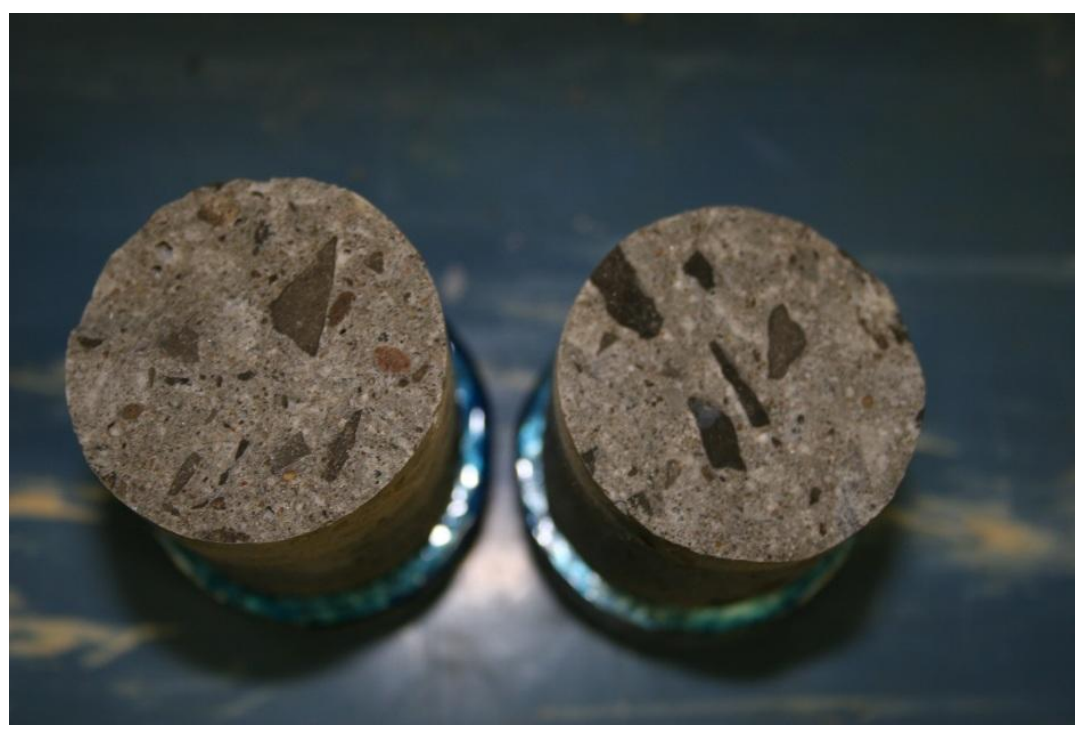

Figure 6.46 Failure through substrate (pull-off)

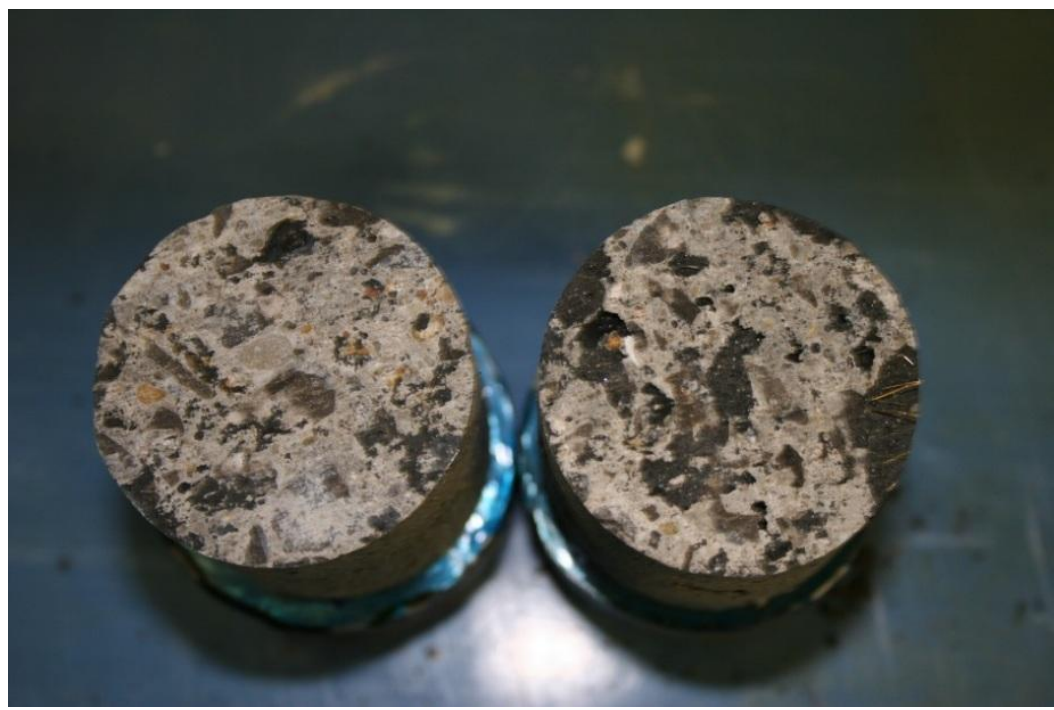

Figure 6.47 Failure through interface (pull-off)

\subsubsection{Results and Discussion}

The results including failure mode of each specimen are presented in Appendix $D$. The average values of bond strength are reported in Table 6.9. 
Table 6.9 Bond strength (by pull-off)

Mix-2 (finer fraction)

\begin{tabular}{|c|c|c|c|c|}
\hline \multirow{3}{*}{$\begin{array}{c}\text { Surface } \\
\text { treatment }\end{array}$} & \multicolumn{4}{|c|}{ Curing condition } \\
\hline & \multicolumn{2}{|c|}{$45^{\circ} \mathrm{C}-\mathrm{W}$} & \multicolumn{2}{|c|}{$55^{\circ} \mathrm{C}-\mathrm{W}$} \\
\hline & $\begin{array}{c}\text { Bond strength } \\
\text { (MPa) }\end{array}$ & $\operatorname{COV}(\%)$ & $\begin{array}{c}\text { Bond strength } \\
\text { (MPa) }\end{array}$ & $\operatorname{COV}(\%)$ \\
\hline Mech & $1.66 \pm 0.1$ & 10.43 & $2.20 \pm 0.1$ & 15.08 \\
\hline Mech + Epoxy & $0.84 \pm 0.5$ & 85.85 & $1.01 \pm 0.1$ & 17.15 \\
\hline $\begin{array}{l}\text { Mech + Epoxy + } \\
\text { Filler }\end{array}$ & $1.00 \pm 0.3$ & 59.16 & $1.23 \pm 0.1$ & 14.08 \\
\hline
\end{tabular}

Note: $1 \mathrm{MPa}=145 \mathrm{psi}$

The above results are plotted in Figure 6.48 and Figure 6.49 below.

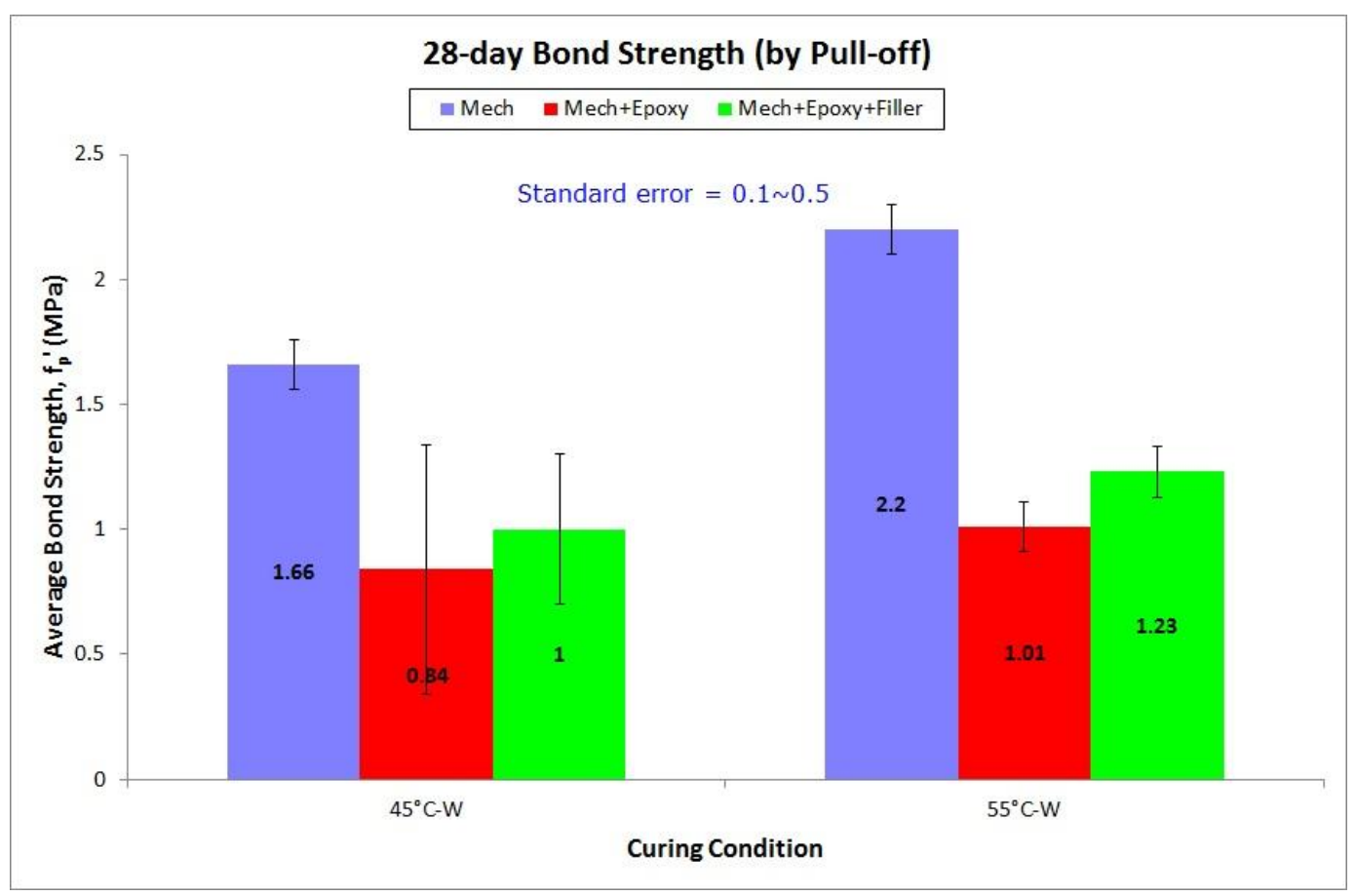

Figure 6.48 Average bond strength by pull-off (curing condition-wise) 


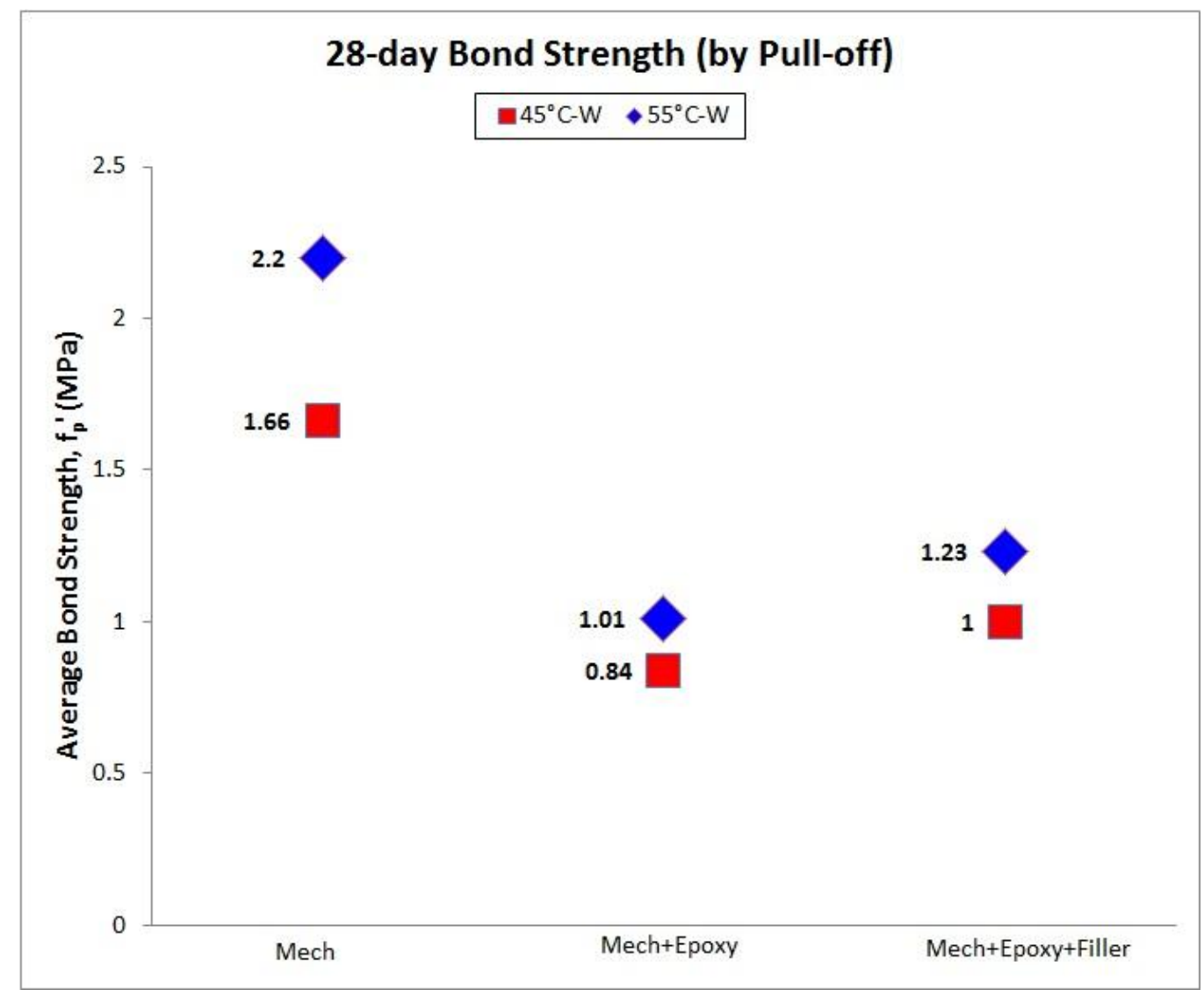

Figure 6.49 Average bond strength by pull-off (surface treatment-wise)

Figure 6.48 shows that for ' $45^{\circ} \mathrm{C}-\mathrm{W}^{\prime}$ ' curing condition, bond strength of specimens with 'Mech' surface treatment is $98 \%$ higher than 'Mech+Epoxy' surface treatment and $66 \%$ higher than 'Mech+Epoxy+Filler' surface treatment. For ' $55^{\circ} \mathrm{C}-\mathrm{W}$ ' curing condition, bond strength of specimens with 'Mech' surface treatment is $118 \%$ and $79 \%$ higher than 'Mech+Epoxy' surface treatment and 'Mech+Epoxy+Filler' surface treatment, respectively. We can infer that very good bonding was achieved through surface treatment by mechanical means only. Also, surface treatment with 'Mech+Epoxy+Filler' produced better results than 'Mech+Epoxy'.

When the same bond strength values are plotted in a different way in Figure 6.49, it shows that for a particular surface treatment, bond strength of specimens cured at higher temperature yielded higher values. The increase in strength ranges from 20 to $33 \%$.

The coefficient of variation (COV) values for the pull-off test lies between $10 \%$ and $86 \%$. Higher COV values were observed for combinations with lesser number of samples. High COV values indicate relatively larger scatter in the data. 
Table 6.10 compares the maximum value of bond strength by pull-off obtained in this study with that of LMC and SFMC overlays developed by (Konduru 2008). It shows that bond strength of HPFRC is $37 \%$ and $45 \%$ higher than that of LMC and SFMC (Konduru 2008), respectively.

Table 6.10 Comparison of bond strength values (pull-off)

Bond strength by pull-off (MPa)

\begin{tabular}{ccc}
\hline HPFRC & LMC $^{\mathbf{a}}$ & SFMC $^{\mathbf{b}}$ \\
(present study) & (Konduru 2008) & (Konduru 2008) \\
\hline 2.2 & 1.61 & 1.52
\end{tabular}

Note: $1 \mathrm{MPa}=145 \mathrm{psi}$

$a=$ Latex modified concrete overlay; $b=$ Silica fume modified concrete overlay

\subsection{Comparison of Bond Strength by Different Tests}

Bond strength values obtained from direct shear test, slant shear test, and pull-off test are compared in Figure 6.50.

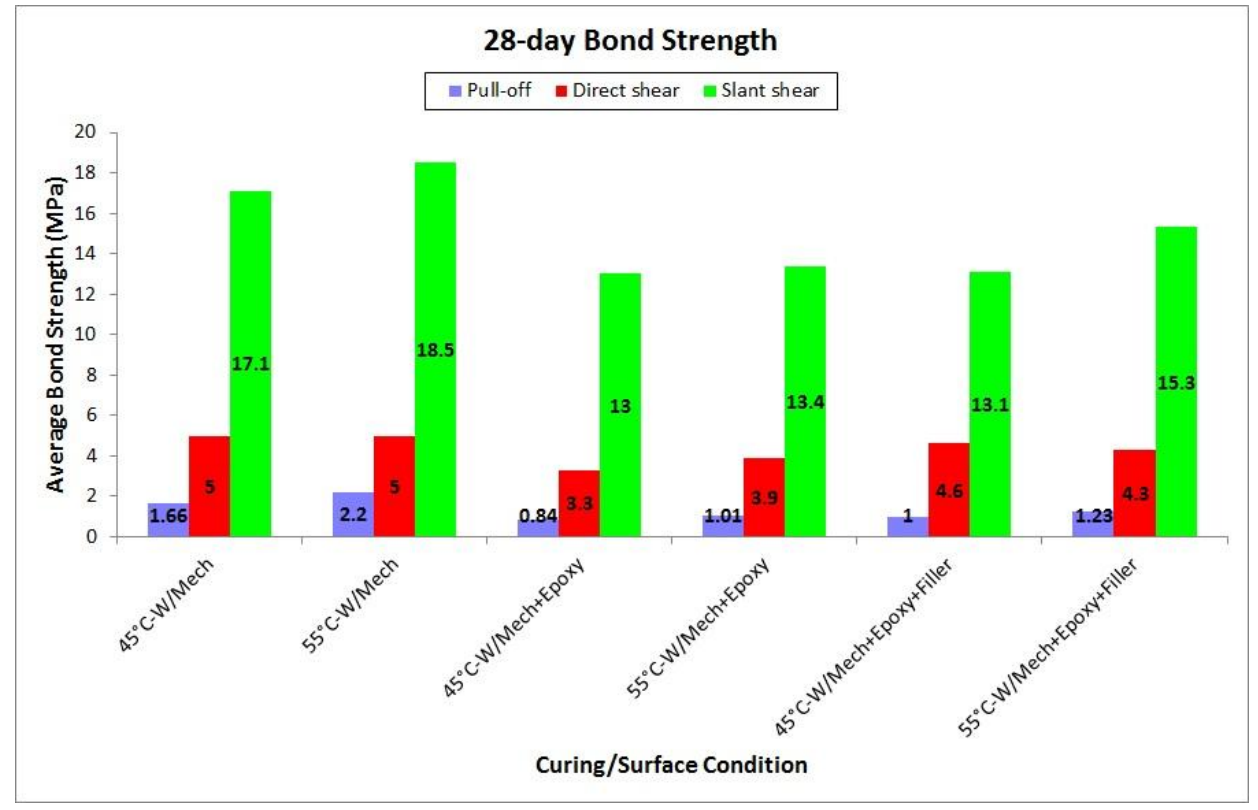

Figure 6.50 Comparison of bond strength by different tests 
Figure 6.50 shows that slant shear test yielded the highest bond strength value and pull-off test yielded the lowest bond strength value for a particular curing/surface condition. The bond strength value by direct shear test lies in between. 


\section{CHAPTER 7 CONCLUSIONS AND FUTURE WORK}

This final chapter summarizes the conclusions drawn in the course of this research and recommends for future work.

\subsection{Conclusions}

An effort was made in this study to develop high performance fiber reinforced concrete using raw materials those are commercially available in the US market. The ultimate goal was to develop and evaluate high performance fiber reinforced concrete as repairing material through lab-scale study. The conclusions drawn in the course of achieving this goal are outlined below:

\subsubsection{Materials and Mixture Proportions}

a. After an extensive review of published literatures, raw materials were carefully selected in order to achieve a densely packed concrete matrix for better strength and durability.

b. Short and discontinuous steel fibers were used to impart post-cracking ductility to the high strength matrix.

c. Addition of water reducing admixture was found to be of paramount importance in developing a workable HPFRC mix with low water to cementitious materials ratio. Full range water reducing admixture and workability retaining admixture were used for this purpose.

d. The mixture proportions were developed by optimizing the particle-size distribution of the fine aggregates.

e. The major challenge was to develop a workable mix with finer particle size (MAS $<0.8 \mathrm{~mm}$ ) compared to normal concrete, $w / \mathrm{cm}$ as low as 0.2 , and discontinuous steel fibers $\left(V_{f}=2 \%\right)$. A systematic procedure for mixing the ingredients was developed.

f. Four different curing regimes with three temperatures were selected to ascertain effect of curing temperature on the hardened properties of HPFRC.

\subsubsection{Isothermal Calorimetry}

a. Mix-2 (finer fraction) was found to be having a faster rate of hydration reaction than Mix-1 (coarser fraction) at $35^{\circ} \mathrm{C}$ and $45^{\circ} \mathrm{C}$. The total heat evolved was also higher in case of Mix-2 (finer fraction). 
b. Both the above mixtures behaved almost identically at $55^{\circ} \mathrm{C}$ due very fast hydration reaction.

\subsubsection{Hardened Properties of HPFRC}

\subsubsection{Compressive Strength}

a. Compressive strength was found to be increasing with the increase in curing temperature.

b. For a particular curing condition, Mix-2 (finer fraction) had better compressive strength than Mix-1 (coarser fraction) due to better packing density.

c. A low average COV value indicates consistency in the test results.

d. A comparison with published literatures revealed that HPFRC developed in this study had better compressive strength compared to ECC (Yao et al. 2012 and Sahmaran and Li 2009) and HPFRCC (Kobayashi et al. 2010, Sirijaroonchai et al. 2010, and Kim et al. 2009).

e. Compressive strength of HPFRC was found to be lower than UHPC (Schäfers and Seim 2011).

\subsubsection{Flexural Strength}

a. Curing temperature played an important role in developing flexural strength of HPFRC; the higher the curing temperature, the better was the flexural strength value.

b. For a particular curing condition, Mix-2 (finer fraction) had better flexural strength compared to Mix-1 (coarser fraction).

c. Less than $12 \% \mathrm{COV}$ value indicates that the results were reasonably consistent throughout the test.

d. Flexural strength of HPFRC was found to be better than FRCC with low strength matrix and $1.2 \%$ high strength steel twisted fibers (Kim et al. 2008) and ECC (Yao et al. 2012).

e. HPFRC had a comparable flexural strength with HPFRCC developed by Kim 2009 with high strength matrix and high strength steel twisted or hooked fibers $\left(V_{f}=1\right.$ to $2 \%)$.

f. The mean value (2.05) of relative flexural strength (calculated as the ratio of flexural strength $\left[\mathrm{f}_{\mathrm{r}}{ }^{\prime}\right]$ to square root of compressive strength $\left[\sqrt{ } \mathrm{f}_{\mathrm{c}}{ }^{\prime}\right]$ ) of HPFRC was found to be $118 \%$ higher than the value (0.94) specified in ACI 363R for highstrength concrete. 


\subsubsection{Deflection Hardening Property and Flexural Toughness}

a. HPFRC material developed in this study exhibited deflection hardening behavior after the first peak load when loaded in flexure. This portion of the load vs. deflection curve was accompanied by multiple cracking. After the peak load, it showed deflection softening behavior. Hence, this material can be used in structural applications where bending prevails (Naaman and Reinhardt 2006).

b. ASTM C1609 recommends determination of toughness at span/600 and span/150 points. However, it was found in this study that toughness calculated at these points would have underestimated the true ductile behavior of the material due to its high load-carrying capacity and high deflection behavior. Hence, in the present study, toughness was calculated at displacements corresponding to the peak load $\left(\delta_{p}\right)$, equal to span/100 $\left(\delta_{L / 100}\right)$, and span/50 $\left(\delta_{L / 50}\right)$. Similar step was taken by (Kim et al. 2008) in their study.

c. The calculated toughness values were found to be comparable with DHFRCC (Kim et al. 2008) and HPFRCC (Kim 2009).

\subsubsection{Bond Behavior between HPFRC and NC}

a. Three different types of bond test, such as, direct shear, slant shear, and pull-off, were carried out to determine the bond strength between HPFRC and NC.

b. Specimens with bond surface roughened with only mechanical means performed the best in all the three tests. Overall, specimens with bond surface treated with 'Mech+Epoxy' performed the worst. Hence, no addition of foreign material as bonding or filling agent is recommended when this HPFRC is used as a repairing material.

c. Increase in curing temperature had little effect in bond strength of HPFRC.

d. In direct shear, bond strength of HPFRC was found to be higher than that of FRC developed by (Luo 2002) and lower than that of FRC developed by (Sun 2004). High COV values indicated large scatted in the test results.

e. In slant shear, HPFRC performed exceptionally well compared to UHPC (Sarkar 2010) and HPC (Konduru 2008). The results were also fairly consistent $(\mathrm{COV}<10 \%)$ in this test.

f. Bond strength of HPFRC in pull-off was found to be higher than that of LMC and SFMC developed by (Konduru 2008). The range of COV values was very high indicating large scatter in the test results. 
g. When the results from the above three tests were compared, it was found that slant shear test yielded the highest bond strength value and pull-off test yielded the lowest bond strength value for a particular curing/surface condition. The bond strength value by direct shear test lied in between.

\subsection{Recommendation for Future Work}

This study was limited to determining the compressive and flexural strength and flexural toughness of HPFRC and the bond strength between HPFRC as a repair material and NC as a substrate. Further studies are necessary in order to assess the feasibility of using HPFRC as a viable repairing material in practice. The following studies are suggested for further assessment of HPFRC:

a. Durability is an important parameter for any cement-based material. There is very limited study to evaluate the effect of freeze-thaw cycles, chloride attack, and sulfate attack on the durability of composite concrete specimens. It is recommended that the effect of freeze-thaw cycles and chloride and sulfate attack on the bond strength between HPFRC and NC be evaluated.

b. Flexural load test was performed in this study in order to ascertain the behavior of HPFRC in flexure. Further direct tensile test can be carried out on dog-boned shaped HPFRC specimens (Wille et al. 2011) in order to determine the tensile strength of HPFRC and the stress-strain behavior of HPFRC under direct tension. Depending on the results of the tensile test, HPFRC, developed in this study, can be further classified as either strain-hardening or strain-softening material (Naaman 2007).

c. Only one type of epoxy-based bonding agent and one type of filler material were used to determine the interface bond strength in this study. This study can be further extended by using other commercially available bonding agents and filler materials in order to determine the bond strength between HPFRC and NC. 


\section{REFERENCES}

ACI 363R (1992), "Report on High-Strength Concrete (Reapproved 1997)", American Concrete Institute, Farmington Hills, MI.

ACI 544.1R (1996), "Report on Fiber Reinforced Concrete (Reapproved 2009)", American Concrete Institute, Farmington Hills, MI.

Ali, M., Kurihara, S., and Matsui, S. (1998), "Bonding shear strength at the interface between old and new concrete", Technology Reports of the Osaka University, 48:237-246.

ASTM A820 (2011), "Standard Specification for Steel Fibers for Fiber Reinforced Concrete", ASTM International, West Conshohocken, PA.

ASTM C33 (2011), "Standard Specification for Concrete Aggregates", ASTM International, West Conshohocken, PA.

ASTM C39 (2011), "Standard Test Method for Compressive Strength of Cylindrical Concrete Specimens", ASTM International, West Conshohocken, PA.

ASTM C150 (2011), "Standard Specification for Portland Cement", ASTM International, West Conshohocken, PA.

ASTM C192 (2007), "Standard Practice for Making and Curing Concrete Test Specimens in the Laboratory", ASTM International, West Conshohocken, PA.

ASTM C260 (2010), "Standard Specification for Air Entraining Admixtures for Concrete", ASTM International, West Conshohocken, PA.

ASTM C494 (2011), "Standard Specification for Chemical Admixtures for Concrete", ASTM International, West Conshohocken, PA.

ASTM C580 (2002), "Standard Test Method for Flexural Strength and Modulus of Elasticity of Chemical-Resistant Mortars, Grouts, Monolithic Surfacings, and Polymer Concretes", ASTM International, West Conshohocken, PA.

ASTM C666 (2008), "Standard Test Method for Resistance of Concrete to Rapid Freezing and Thawing", ASTM International, West Conshohocken, PA. 
ASTM C882 (2005), "Standard Test Method for Bond Strength of Epoxy-Resin Systems Used With Concrete By Slant Shear", ASTM International, West Conshohocken, PA.

ASTM C1240 (2011), "Standard Specification for Silica Fume Used in Cementitious Mixtures", ASTM International, West Conshohocken, PA.

ASTM C1583 (2004), "Standard Test Method for Tensile Strength of Concrete Surfaces and the Bond Strength or Tensile Strength of Concrete Repair and Overlay Materials by Direct Tension (Pull-off Method)", ASTM International, West Conshohocken, PA.

ASTM C1609 (2010), "Standard Test Method for Flexural Performance of Fiber-Reinforced Concrete (Using Beam With Third-Point Loading)", ASTM International, West Conshohocken, PA.

ASTM C1679 (2009), "Standard Practice for Measuring Hydration Kinetics of Hydraulic Cementitious Mixtures Using Isothermal Calorimetry", ASTM International, West Conshohocken, PA.

Atis, C. D. and Karahan, O. (2009), "Properties of steel fiber reinforced fly ash concrete", Construction and Building Materials, 23:392-399.

Balaguru, P. and Ramakrishnan, V. (1987), "Comparison of Slump Cone and V-B Tests as Measures of Workability for Fiber Reinforced and Plain Concrete," ASTM Journal, Cement, Concrete and Aggregates, 9:3-11.

Balaguru, P. and Ramakrishnan, V. (1988), "Properties of Fiber Reinforced Concrete: Workability Behavior Under Long Term Loading and Air-Void Characteristics", ACI Materials Journal, 85:189-196.

Balaguru, P. and Shah, S. P. (1992), "Fiber Reinforced Cement Composites", McGraw Hill, NY.

Bentur, A. and Mindess, S. (1990), "Fiber Reinforced Cementitious Composites", Elsevier Applied Science, London, UK.

Biryukovich, K. L. and Yu, D. L. (1965), "Glass Fiber Reinforced Cement," translated by G. L. Cairns, CERA Translation, No. 12, Civil Eng. Res. Assoc., London, 41 pp. 
Brandt, A., Li, V. C., and Marshall, I. H. (Editors, 2000), "Brittle Matrix Composites 6, BMC6,", Woodhead Publishing Limited, Cambridge and Warsaw.

Chen, W. and Carson, J. L. (1971), "Stress-Strain Properties of Random Wire Reinforced Concrete," ACI Journal, Proceedings, 68:933-936.

Dhir, M. P. (1984), "A Study on the Effect of Temperature Variations on the Bonding of Concrete Overlays", Journal of the American Concrete Institute, 81:172-179.

Dixon, J. and Mayfield, B. (1971), "Concrete Reinforced with Fibrous Wire", Journal of the Concrete Society, Concrete, 5:73-76.

Hannant, D. J. (1978), "Fiber Cements and Fiber Concretes", J. Wiley, 215 pp.

ICRI 03732, "Selecting and Specifying Concrete Surface Preparation for Coatings, Sealers, and Polymer Overlays", International Concrete Repair Institute, Rosemont, IL.

Imani, F. S. (2010), "Traction-Separation Law for CFRP-Concrete Interface Fracture under Mode II Loading", Master's Thesis, West Virginia University, WV.

Johnston, C. D. (1984), "Measures of the Workability of Steel Fiber Reinforced Concrete and Their Precision," Cement, Concrete and Aggregates, 6:74-83.

Johnston, C. D. (1974), "Steel Fibre Reinforced Mortar and Concrete-A Review of Mechanical Properties", Fiber Reinforced Concrete, SP-44, American Concrete Institute, Farmington Hills, Mich., pp. 127-142.

Johnston, C. D. (1986), "Toughness of Steel Fiber Reinforced Concrete", Steel Fiber Concrete, Elsevier Applied Science Publishers Ltd., pp. 333-360.

Kar, N. J. and Pal, A. K. (1972), "Strength of Fiber Reinforced Concrete", Journal of the Structural Division, Proceedings, ASCE, 98:1053-1068.

Kanda, T. and Li, V. C. (1999), "New Micromechanics Design Theory for Pseudostrain Hardening Cementitious Composite", ASCE Journal of Engineering Mechanics, $125: 373-381$. 
Karihaloo, B. L. and Wang, J. (1997), "Micromechanical Modeling and Strain Hardening and Tensile Softening in Cementitious Composites", Journal of Computational Mechanics, 19:453-462.

Kim, D. J. (2009), "Strain Rate Effect on High Performance Fiber Reinforced Cementitious Composites using Slip Hardening High Strength Deformed Steel Fibers", Ph.D. Dissertation, The University of Michigan, MI.

Kim, D. J., El-Tawil, S., and Naaman, A. E. (2009), "Rate-dependent tensile behavior of high performance fiber reinforced cementitious composites", Materials and Structures, 42:399-414.

Kim, D. J., Naaman, A. E., and El-Tawil, S. (2008), "Comparative flexural behavior of four fiber reinforced cementitious composites", Cement \& Concrete Composites 30:917928.

Kobayashi, K., Iizuka, T., Kurachi, H., and Rokugo, K. (2010), "Corrosion protection performance of High Performance Fiber Reinforced Cement Composites as a repair material", Cement \& Concrete Composites, 32:411-420.

Konduru, S. (2008), "Performance evaluations of latex-modified and silica fume modified concrete overlays for bridge deck", Master's Thesis, West Virginia University, WV.

Krenchel, H. and Shah, S. (1985), "Applications of Polypropylene Fibers in Scandinavia", Concrete International.

$\mathrm{Li}$, V. C. (1993), "From Micromechanics To Structural Engineering -- The Design Of Cementitious Composites For Civil Engineering Applications", JSCE Journal of Structural Mechanics and Earthquake Engineering, 10:37-48.

Li, V. C. (2003), "On Engineered Cementitious Composites (ECC) - A Review of the Material and Its Applications", Journal of Advanced Concrete Technology, 1:215-230.

$\mathrm{Li}$, V. C. and Kanda, T. (1998), "Engineered Cementitious Composites for Structural Applications", ASCE Journal of Materials in Civil Engineering, 10:66-69.

Li, V.C. and Leung, C. K. Y. (1992), "Steady State And Multiple Cracking Of Short Random Fiber Composites", ASCE Journal of Engineering Mechanics, 118:2246-2264. 
Luo, S. (2002), "Evaluations of Concrete Overlays for Bridge Deck Applications", Master's Thesis, West Virginia University, WV.

Majumdar, A. J. and Ryder, J. R. (1968), "Glass fiber reinforcement of cement products", Glass Technology, 9:78-84.

MathWorks (2011), "Boxplot - R2011b Documentation", Natick, MA.

Mohammadi, Y, Singh, S. P., and Kaushik, S. K. (2008), "Properties of steel fibrous concrete containing mixed fibres in fresh and hardened state", Construction and Building Materials, 22:956-965.

Naaman, A. E. (1985), "Fiber Reinforcement for Concrete", Concrete International.

Naaman, A. E. (2007), "High Performance Fiber Reinforced Cement Composites: Classification and Applications", CBM-CI International Workshop, Karachi, Pakistan.

Naaman, A. E. and Reinhardt, H. W. (2006), "Proposed classification of HPFRC composites based on their tensile response", Materials and Structures, 39:547-555.

Nanni, A. (1991), "Ductility of Fiber Reinforced Concrete", Journal of Materials in Civil Engineering, ASCE, 3:78-90.

O'Connor, D. N. and Saiidi, M. (1993), "Compatibility of polyester-styrene polymer concrete overlays with portland cement concrete bridge decks", ACI Materials Journal, 90:5968.

Ramakrishnan, V. (1987), "Materials and Properties of Fiber Concrete", Proceedings of the International Symposium on Fiber Reinforced Concrete, Madras, India, 1:2.3-2.23.

Roadmap 2030 (2002), "The U.S. Concrete Industry Technology Roadmap (version 1.0)", Concrete Research and Education Foundation, USA.

Romualdi, J. P. and Mandel, J. A. (1964), "Tensile Strength of Concrete Affected by Uniformly Distributed Closely Spaced Short Lengths of Wire Reinforcement," ACI JOURNAL, Proceedings 61:657-671.

Şahmaran, M. and Li, V. C. (2009), "Durability properties of micro-cracked ECC containing high volumes fly ash", Cement and Concrete Research, 39:1033-1043. 
Sarkar, J. (2010), "Characterization of the Bond Strength between Ultra High Performance Concrete Bridge Deck Overlays and Concrete Substrates", Master's Thesis, Michigan Technological University, MI.

Schäfers, M. and Seim, W. (2011), "Investigation on bonding between timber and ultra-high performance concrete (UHPC)", Construction and Building Materials, (in press) doi:10.1016/j.conbuildmat.2010.12.060.

Shah, S. P. and Rangan, R. V. (1971), "Fiber Reinforced Concrete Properties", ACI Journal, Proceedings, 68:126-135.

Shah, S. P. and Winter, G. (1966), "Inelastic Behavior and Fracture of Concrete," ACI Journal, Proceedings, 63:925-930.

Sirijaroonchai, K., El-Tawil, S., and Parra-Montesinos, G. (2010), "Behavior of high performance fiber reinforced cement composites under multi-axial compressive loading", Cement \& Concrete Composites, 32:62-72.

Snyder, M. L. and Lankard, D. R. (1972), "Factors Affecting the Strength of Steel Fibrous Concrete," ACI Journal, Proceedings, 69:96-100.

Sprinkel, M. M. (1988), "High early strength latex-modified concrete overlay", Transportation Research Record, p 42-51.

Sun, Z. (2004), "Evaluation of Concrete Bridge Deck Overlays", Master's Thesis, West Virginia University, WV.

Taylor, H. F. W. (1997), "Cement chemistry", ThomasTelford, 2nd edition.

Wille, K., Naaman, A. E., and El-Tawil, S. (2011), "Optimizing Ultra-High-Performance FiberReinforced Concrete", Concrete International, 33:35-41.

Wille, K., Naaman, A. E., and Parra-Montesinos, G. J. (2011), "Ultra-High Performance Concrete with Compressive Strength Exceeding 150 MPa (22 ksi): A Simpler Way", ACI Materials Journal, Title no. 108-M06.

Williamson, G. R. (1974), "The Effect of Steel Fibers on the Compressive Strength of Concrete", SP-44: Fiber Reinforced Concrete, American Concrete Institute, Farmington Hills, MI, pp. 195-207. 
Works, R. H. and Untrauer, R. E. (1964), "Discussion of Tensile Strength of Concrete Affected by Uniformly Distributed and Closely Spaced Short Lengths of Wire Reinforcement", ACI Journal, Proceedings, 61:1653-1656.

Yao, Y., Zhu, Y., and Yang, Y. (2012), "Incorporation superabsorbent polymer (SAP) particles as controlling pre-existing flaws to improve the performance of engineered cementitious composites", Construction and Building Materials, 28:139-145.

Yudenfreund, M., Odler, I., and Brunauer, S. (1972a), "Hardened Portland Cement Pastes of Low Porosity I. Materials and Experimental Methods", Cement and Concrete Research, 2:313-330. 


\section{APPENDIX A}

Table A-1 Bond strength results (by Direct Shear)

\begin{tabular}{|c|c|c|c|c|c|c|}
\hline \multirow[b]{3}{*}{ Specimen ID } & \multicolumn{5}{|c|}{ 28-day Bond strength, $f_{s}^{\prime}(M P a)$} & \multirow{2}{*}{ 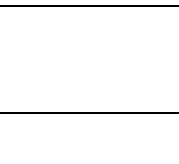 } \\
\hline & \multicolumn{3}{|c|}{$45^{\circ} \mathrm{C}-\mathrm{W}$} & \multicolumn{2}{|r|}{$55^{\circ} \mathrm{C}-\mathrm{W}$} & \\
\hline & Mech & $\begin{array}{c}\text { Mech + } \\
\text { Epoxy }\end{array}$ & $\begin{array}{c}\text { Mech + } \\
\text { Epoxy + } \\
\text { Filler }\end{array}$ & Mech & $\begin{array}{c}\text { Mech + } \\
\text { Epoxy }\end{array}$ & $\begin{array}{c}\text { Mech + } \\
\text { Epoxy + } \\
\text { Filler }\end{array}$ \\
\hline 1 & 5.3 & 2.4 & 3.4 & 1.4 & 4.9 & 7.2 \\
\hline 2 & 3.2 & 2.5 & 6.7 & 6.4 & 2.1 & 5.7 \\
\hline 3 & 3.8 & 4.5 & 3.6 & 7.7 & 17.4 & 7.1 \\
\hline 4 & 3.3 & 5.5 & 4.3 & 6.2 & 4.7 & 1.9 \\
\hline 5 & 4.8 & 3.8 & 6.7 & 4.3 & 4.4 & 1.3 \\
\hline 6 & 6.1 & 2.4 & 1.4 & 4.4 & 4.5 & 0.5 \\
\hline 7 & 5.5 & 3.4 & 5.0 & 1.7 & 4.6 & 4.7 \\
\hline 8 & 6.3 & 2.2 & 8.7 & 6.2 & 2.1 & 5.8 \\
\hline 9 & 7.1 & 3.2 & 1.7 & 6.6 & 7.3 & 4.7 \\
\hline
\end{tabular}

Note: $1 \mathrm{MPa}=145 \mathrm{psi}$ 


\section{APPENDIX B}

\section{MATLAB code to detect outliers in direct shear test}

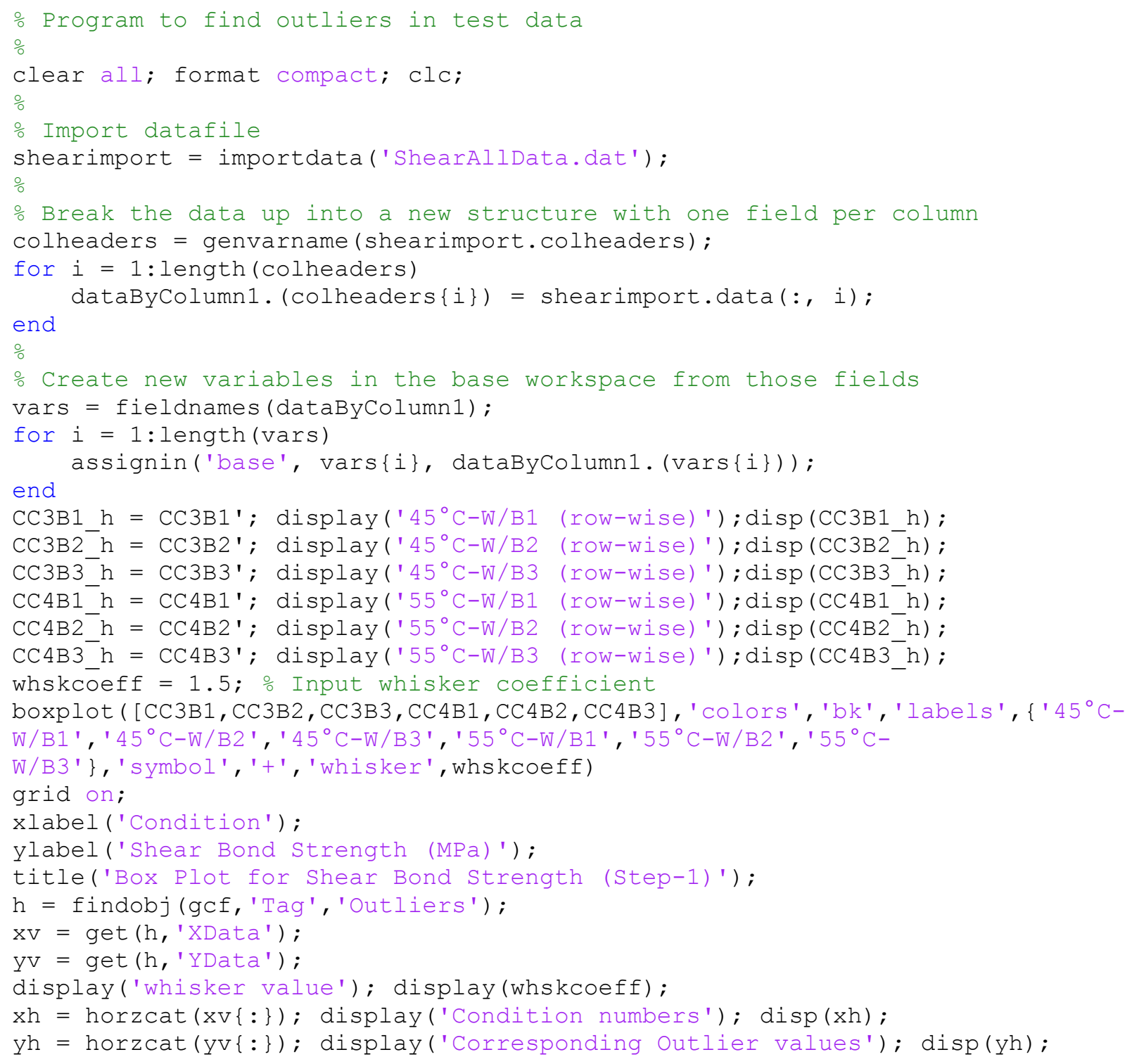




\section{APPENDIX C}

Table C-1 Bond strength results by Slant Shear (14-day)

\begin{tabular}{|c|c|c|c|c|c|}
\hline \multicolumn{3}{|c|}{ Specimen } & \multicolumn{2}{|c|}{ 14-day Bond strength, $\mathrm{f}_{\mathrm{sl}}^{\prime}$ (MPa) } & \multirow{2}{*}{$\begin{array}{c}\text { Failure modes } \\
\text { (visual inspection) }\end{array}$} \\
\hline $\begin{array}{l}\text { Curing } \\
\text { condition }\end{array}$ & $\begin{array}{c}\text { Surface } \\
\text { treatment }\end{array}$ & ID & $\begin{array}{l}\text { Interface bond } \\
\text { strength (MPa) }\end{array}$ & $\begin{array}{l}\text { Minimum bond } \\
\text { strength ( } \mathrm{MPa} \text { ) }\end{array}$ & \\
\hline \multirow{10}{*}{$45^{\circ} \mathrm{C}-\mathrm{W}$} & \multirow{3}{*}{ Mech } & 1 & 15.6 & - & Through interface \\
\hline & & 2 & 16.0 & - & Through interface \\
\hline & & 3 & 19.6 & - & Through interface \\
\hline & \multirow{3}{*}{$\begin{array}{l}\text { Mech + } \\
\text { Epoxy }\end{array}$} & 1 & - & 11.0 & Mixed mode \\
\hline & & 2 & - & 11.9 & Mixed mode \\
\hline & & 3 & 16.2 & - & Through interface \\
\hline & \multirow{4}{*}{$\begin{array}{c}\text { Mech + } \\
\text { Epoxy + } \\
\text { Filler }\end{array}$} & 1 & 13.1 & - & Through interface \\
\hline & & 2 & - & 13.6 & Through substrate \\
\hline & & & & & \\
\hline & & 3 & 12.7 & - & Through interface \\
\hline \multirow{7}{*}{$55^{\circ} \mathrm{C}-\mathrm{W}$} & \multirow{3}{*}{ Mech } & 1 & 16.7 & - & Through interface \\
\hline & & 2 & 22.5 & - & Through interface \\
\hline & & 3 & - & 16.2 & Through substrate \\
\hline & \multirow{3}{*}{$\begin{array}{l}\text { Mech + } \\
\text { Epoxy }\end{array}$} & 1 & 14 & - & Through interface \\
\hline & & 2 & - & 11.1 & Through substrate \\
\hline & & 3 & - & 15.1 & Through substrate \\
\hline & Mech + & 1 & 14.1 & - & Through interface \\
\hline
\end{tabular}




\begin{tabular}{|c|c|c|c|c|c|}
\hline & $\begin{array}{c}\text { Epoxy }+ \\
\text { Filler }\end{array}$ & 2 & - & 15.0 & Through substrate \\
\cline { 3 - 5 } & & 3 & 16.8 & - & Through interface \\
\hline
\end{tabular}

Note $1: 1 \mathrm{MPa}=145 \mathrm{psi}$

Note 2: "Mixed mode" means failure occurred through both interface and substrate.

Table C-2 Bond strength results by Slant Shear (28-day)

\begin{tabular}{|c|c|c|c|c|c|}
\hline \multicolumn{3}{|c|}{ Specimen } & \multicolumn{2}{|c|}{ 28-day Bond strength, $\mathrm{f}_{\mathrm{sl}}^{\prime}$ (MPa) } & \multirow{2}{*}{$\begin{array}{c}\text { Failure modes } \\
\text { (visual inspection) }\end{array}$} \\
\hline $\begin{array}{c}\text { Curing } \\
\text { condition }\end{array}$ & $\begin{array}{c}\text { Surface } \\
\text { treatment }\end{array}$ & ID & $\begin{array}{l}\text { Interface bond } \\
\text { strength (MPa) }\end{array}$ & $\begin{array}{l}\text { Minimum bond } \\
\text { strength ( } \mathrm{MPa})\end{array}$ & \\
\hline \multirow{14}{*}{$45^{\circ} \mathrm{C}-\mathrm{W}$} & \multirow{5}{*}{ Mech } & 1 & 20.9 & - & Through interface \\
\hline & & 2 & 20.5 & - & Through interface \\
\hline & & 3 & - & 20.1 & Mixed mode \\
\hline & & 4 & - & 20.8 & Through substrate \\
\hline & & 5 & 18.3 & - & Through interface \\
\hline & \multirow{5}{*}{$\begin{array}{l}\text { Mech + } \\
\text { Epoxy }\end{array}$} & 1 & - & 12.9 & Through substrate \\
\hline & & 2 & - & 16.2 & Through substrate \\
\hline & & 3 & 14.6 & - & Through interface \\
\hline & & 4 & - & 16.2 & Mixed mode \\
\hline & & 5 & - & 13.9 & Through substrate \\
\hline & \multirow{4}{*}{$\begin{array}{c}\text { Mech + } \\
\text { Epoxy + } \\
\text { Filler }\end{array}$} & 1 & 15.5 & - & Through interface \\
\hline & & 2 & - & 10.0 & Through substrate \\
\hline & & & & & \\
\hline & & 3 & 16.8 & - & Through interface \\
\hline
\end{tabular}




\begin{tabular}{|c|c|c|c|c|c|}
\hline \multicolumn{3}{|c|}{ Specimen } & \multicolumn{2}{|c|}{ 28-day Bond strength, $\mathrm{f}_{\mathrm{sl}}{ }^{\prime}$ (MPa) } & \multirow{2}{*}{$\begin{array}{c}\text { Failure modes } \\
\text { (visual inspection) }\end{array}$} \\
\hline $\begin{array}{l}\text { Curing } \\
\text { condition }\end{array}$ & $\begin{array}{c}\text { Surface } \\
\text { treatment }\end{array}$ & ID & $\begin{array}{l}\text { Interface bond } \\
\text { strength (MPa) }\end{array}$ & $\begin{array}{l}\text { Minimum bond } \\
\text { strength ( } \mathrm{MPa})\end{array}$ & \\
\hline \multirow{2}{*}{$45^{\circ} \mathrm{C}-\mathrm{W}$} & \multirow{2}{*}{$\begin{array}{c}\text { Mech + } \\
\text { Epoxy + } \\
\text { Filler }\end{array}$} & 4 & - & 13.5 & Mixed mode \\
\hline & & 5 & 15.9 & - & Through interface \\
\hline \multirow{13}{*}{$55^{\circ} \mathrm{C}-\mathrm{W}$} & \multirow{4}{*}{ Mech* } & 1 & - & 20.6 & Through substrate \\
\hline & & 2 & - & 18.3 & Through substrate \\
\hline & & 3 & - & 23.3 & Through substrate \\
\hline & & 4 & - & 22.4 & Through substrate \\
\hline & \multirow{4}{*}{$\begin{array}{l}\text { Mech + } \\
\text { Epoxy* }\end{array}$} & 1 & - & 17.2 & Mixed mode \\
\hline & & 2 & - & 16.0 & Through substrate \\
\hline & & 3 & - & 14.3 & Through substrate \\
\hline & & 4 & - & 16.1 & Through substrate \\
\hline & \multirow{5}{*}{$\begin{array}{c}\text { Mech + } \\
\text { Epoxy + } \\
\text { Filler }\end{array}$} & 1 & 16.1 & - & Through interface \\
\hline & & 2 & 15.1 & - & Through interface \\
\hline & & 3 & - & 15.7 & Through substrate \\
\hline & & 4 & - & 17.4 & Mixed mode \\
\hline & & 5 & 16.5 & - & Through interface \\
\hline
\end{tabular}

* Due to abnormally low value of strength, one specimen was discarded.

Note 1: $1 \mathrm{MPa}=145 \mathrm{psi}$

Note 2: "Mixed mode" means failure occurred through both interface and substrate. 


\section{APPENDIX D}

Table D-1 Bond strength results by Pull-off (28-day)

\begin{tabular}{|c|c|c|c|c|c|}
\hline \multicolumn{3}{|c|}{ Specimen } & \multicolumn{2}{|c|}{ 28-day Bond strength, $\mathrm{f}_{\mathrm{p}}^{\prime}(\mathrm{MPa})$} & \multirow{2}{*}{$\begin{array}{c}\text { Failure modes } \\
\text { (visual inspection) }\end{array}$} \\
\hline $\begin{array}{c}\text { Curing } \\
\text { condition }\end{array}$ & $\begin{array}{c}\text { Surface } \\
\text { treatment }\end{array}$ & ID & $\begin{array}{l}\text { Interface bond } \\
\text { strength (MPa) }\end{array}$ & $\begin{array}{l}\text { Minimum bond } \\
\text { strength ( } \mathrm{MPa} \text { ) }\end{array}$ & \\
\hline \multirow{11}{*}{$45^{\circ} \mathrm{C}-\mathrm{W}$} & \multirow{5}{*}{ Mech } & 1 & 1.65 & - & Through interface \\
\hline & & 2 & 1.40 & - & Through interface \\
\hline & & 3 & - & 1.87 & Through substrate \\
\hline & & 4 & - & 1.73 & Through substrate \\
\hline & & 5 & - & 1.65 & Through substrate \\
\hline & \multirow{2}{*}{$\begin{array}{l}\text { Mech + } \\
\text { Epoxy }\end{array}$} & 1 & 0.33 & - & Through interface \\
\hline & & 2 & 1.35 & - & Through interface \\
\hline & \multirow{4}{*}{$\begin{array}{c}\text { Mech + } \\
\text { Epoxy + } \\
\text { Filler }\end{array}$} & 1 & 1.78 & - & Through interface \\
\hline & & 2 & 1.15 & - & Through interface \\
\hline & & 3 & - & 0.58 & Through substrate \\
\hline & & 4 & - & 0.50 & Through substrate \\
\hline \multirow{5}{*}{$55^{\circ} \mathrm{C}-\mathrm{W}$} & \multirow{5}{*}{ Mech } & 1 & 2.09 & - & Through interface \\
\hline & & 2 & 1.78 & - & Through interface \\
\hline & & 3 & - & 2.27 & Through substrate \\
\hline & & 4 & - & 2.15 & Through substrate \\
\hline & & 5 & - & 2.70 & Through substrate \\
\hline
\end{tabular}




\begin{tabular}{|c|c|c|c|c|c|}
\hline \multicolumn{3}{|c|}{ Specimen } & \multicolumn{2}{|c|}{ 28-day Bond strength, $f_{p}^{\prime}(M P a)$} & \multirow{2}{*}{$\begin{array}{c}\text { Failure modes } \\
\text { (visual inspection) }\end{array}$} \\
\hline $\begin{array}{c}\text { Curing } \\
\text { condition }\end{array}$ & $\begin{array}{c}\text { Surface } \\
\text { treatment }\end{array}$ & ID & $\begin{array}{l}\text { Interface bond } \\
\text { strength ( } \mathrm{MPa} \text { ) }\end{array}$ & $\begin{array}{l}\text { Minimum bond } \\
\text { strength ( } \mathrm{MPa} \text { ) }\end{array}$ & \\
\hline \multirow{9}{*}{$55^{\circ} \mathrm{C}-\mathrm{W}$} & \multirow{5}{*}{$\begin{array}{c}\text { Mech + } \\
\text { Epoxy }\end{array}$} & 1 & 0.94 & - & Through interface \\
\hline & & 2 & 1.23 & - & Through interface \\
\hline & & 3 & 0.91 & - & Through interface \\
\hline & & 4 & 1.12 & - & Through interface \\
\hline & & 5 & 0.85 & - & Through interface \\
\hline & \multirow{4}{*}{$\begin{array}{c}\text { Mech + } \\
\text { Epoxy + } \\
\text { Filler }\end{array}$} & 1 & 1.29 & - & Through interface \\
\hline & & 2 & 1.46 & - & Through interface \\
\hline & & 3 & - & 1.09 & Through substrate \\
\hline & & 4 & - & 1.07 & Through substrate \\
\hline
\end{tabular}

Note 1: $1 \mathrm{MPa}=145 \mathrm{psi}$

Note 2: Specimens failed at epoxy/HPFRC interface are not reported above. 